ROSÂNGELA DOS SANTOS MOTTA

ESTUDO DE MISTURAS ASFÁLTICAS MORNAS EM REVESTIMENTOS DE PAVIMENTOS PARA REDUÇÃO DE EMISSÃO DE POLUENTES E DE CONSUMO ENERGÉTICO 
ROSÂNGELA DOS SANTOS MOTTA

\section{ESTUDO DE MISTURAS ASFÁLTICAS MORNAS EM REVESTIMENTOS DE PAVIMENTOS PARA REDUÇÃO DE EMISSÃO DE POLUENTES E DE CONSUMO ENERGÉTICO}

Tese apresentada à Escola Politécnica da Universidade de São Paulo para obtenção do título de Doutor em Engenharia

Área de concentração:

Engenharia de Transportes

Orientador: Prof $\stackrel{a}{-}$ Titular

Liedi Légi Bariani Bernucci

São Paulo 
Este exemplar foi revisado e alterado em relação à versão original, sob responsabilidade única do autor e com a anuência de seu orientador.

São Paulo, 06 de junho de 2011.

Assinatura do autor

Assinatura do orientador

\section{FICHA CATALOGRÁFICA}

Motta, Rosângela dos Santos

Estudo de misturas asfálticas mornas em revestimentos de pavimentos para redução de emissão de poluentes e de consumo energético / R.S. Motta. -- ed.rev. -- São Paulo, 2011. $229 \mathrm{p}$.

Tese (Doutorado) - Escola Politécnica da Universidade de São Paulo. Departamento de Engenharia de Transportes.

1.Pavimentação asfáltica 2.Poluição (Redução) 3.Energia (Redução) I.Universidade de São Paulo. Escola Politécnica. Departamento de Engenharia de Transportes II.t. 
O presente trabalho foi realizado com o apoio da

Coordenação de Aperfeiçoamento de Pessoal de Nível Superior (CAPES) 


\section{DEDICATÓRIA}

Ao meu filho Leonardo, com muita saudade e ao meu querido marido Giovanni 


\section{AGRADECIMENTOS}

Agradeço a todos aqueles que, de alguma forma, colaboraram com este trabalho ao longo desses anos, mas em especial quero agradecer:

À minha grande professora-amiga Liedi, pela oportunidade de fazer parte da família LTP, pelos valiosos ensinamentos e pelo incentivo e ânimo em momentos difíceis;

À nossa querida secretária do LTP Diomária, tão prestativa e amiga;

Aos técnicos do LTP, Edson, Erasmo e Kendi, pela grande ajuda de sempre;

Aos colegas do LTP que têm sido grandes companheiros no dia-a-dia: Ana Luisa, Bruno, Daniel, Kamis, Manu, Mariana, Mary, Renato, Serginho, Tiago;

...especialmente aos alunos de iniciação científica que colaboraram muito com esta tese: Ana Maria, Claudio e Gabriel;

...e aos colegas que compartilharam comigo esta jornada, mas atualmente trilham outros caminhos: Amanda, Ana Furlan, Fabi, Pati B, Pati N, Rosely, Sidney, Talita, Walter;

Aos colegas da secretaria do PTR, em especial Edson, Luciana e Simone pelo auxílio em diversos momentos;

Ao professor Jorge Ceratti e à professora-amiga Kamilla (de novo) pelas valiosas contribuições no exame de qualificação e na defesa desta Tese;

Ao professor Yves Brosseaud e à professora Anne Dony, além da pesquisadora Valèrie Viranaiken, que gentilmente me acolheram durante a visita à ESTP/Paris e ao LCPC/Nantes, e que tanto colaboraram para a minha pesquisa;

À professora Pérola Vasconcellos e à pesquisadora Simone Ávila, do Instituto de Química da USP, que contribuíram significativamente com o estudo de emissões, iniciando uma parceria de pesquisa que se espera ser produtiva e douradora;

À CAPES, pela bolsa de doutorado;

Ao $C N P q$ pelo Projeto Universal que me proporcionou a visita às instituições de pesquisa francesas, além da obtenção de insumos para os estudos no LTP;

À ANTT pelos investimentos em pesquisa, na forma de Recursos de Desenvolvimento Tecnológico (RDT);

Ao Grupo CCR, particularmente à Engelog, NovaDutra e AutoBAn, em nome de: Assis, Claudio Renato, Décio, Gustavo Anfra, Sales, Valéria, Wilson e toda a 
equipe que nos proporcionou e nos apoiou na execução e acompanhamento dos dois trechos experimentais;

A Fernando e Jasmim Leal, da Quimigel, pelo fornecimento de aditivo e pela colaboração com a pesquisa;

À Serveng Barueri, nas pessoas de Romualdo e Honorato e equipe, pelo fornecimento e transporte de materiais, informações, além da colaboração com a parte de usina no trecho experimental da Rodovia Presidente Dutra;

e aos profissionais que participaram da etapa de pista de tal segmento, não só durante a execução da obra, mas também nos levantamentos posteriores, em nome de Alexandre (Peixe) e Francelino da Concremat;

Ao Grupo Estrutural, particularmente às equipes de usina da Basalto e aos trabalhadores de pista, respectivamente nas pessoas de Marcos e Cícero, que nos recepcionaram em seus laboratórios da usina, forneceram informações e nos deram todo o apoio durante as medidas de emissões e o acompanhamento da execução dos segmentos teste na Rodovia dos Bandeirantes;

e à Ductor, especialmente a Daniel, Fabio e Alison, por ocasião de minhas idas e vindas entre a usina e a pista no trecho experimental da Rodovia dos Bandeirantes, que tanto colaboraram com o meu trabalho, inclusive com o transporte de materiais até o LTP por parte do Daniel.

À Greca Asfaltos, em particular a Agnaldo, William e Wander, que sempre nos deram apoio, fornecendo ligantes e informações;

À Imperpav, especialmente a Kamarão e Fernando, pela colaboração com ensaios;

Às pesquisadoras da Petrobras Margareth Cravo (Margot) pela troca de "figurinhas" relativas às emissões asfálticas, e Leni Leite pelas contribuições na defesa desta Tese. No mais, também agradeço à própria Petrobras, em nome de Ronaldo Monteiro, pela oportunidade de divulgar nossa pesquisa junto a seus colaboradores por ocasião do Planasf 2011;

Às minhas queridas e amadas famílias Motta e Manassero pelo apoio que sempre me proporcionaram ao longo de toda essa jornada;

Ao meu querido amor-marido-pesquisador-professor Giovanni, companheiro de todos os momentos, a quem agradeço o incentivo e a força para ter chegado até aqui. 
"Come il ferro in disuso arruginisce, cosi l'inazione sciupa l'intelletto." 


\section{RESUMO}

Nos últimos anos tem havido uma crescente preocupação com o meio ambiente. Dentro deste contexto, surgiram as misturas asfálticas mornas que, devido à diminuição de temperatura na usinagem e na compactação, têm impacto positivo não só sobre a poluição ambiental, mas também sobre o consumo energético. Este estudo compara o comportamento de misturas asfálticas mornas (com aditivo surfactante) com o de misturas similares usinadas a quente (convencionais), por meio de ensaios laboratoriais de compactação, de propriedades mecânicas, além de testes complementares. Os resultados apontam que não há necessidade de alteração do método de dosagem convencional para as misturas mornas, e que o teor de ligante de projeto das misturas mornas deve ser mantido igual à da similar a quente. Porém, os resultados dependem muito do tipo de ligante, do teor de asfalto utilizado e do nível de diminuição da temperatura de usinagem e compactação. O controle da temperatura e a magnitude de sua redução demonstraram ser essenciais na qualidade final da mistura morna nesta tecnologia. Além disso, tem-se o acompanhamento de dois trechos experimentais, onde não foram verificadas dificuldades complementares de usinagem e de execução em pista. Os resultados de controle tecnológico da obra e de avaliação dos aspectos de superfície nos trechos com mistura morna se mostraram similares aos das técnicas a quente. Foram analisadas as emissões de poluentes (HPAs prioritários no material particulado) de misturas asfálticas mornas e a quente, tanto no programa laboratorial, quanto em usina e em pista, por ocasião da execução de um dos trechos experimentais. Os resultados indicaram que houve redução em cerca de três vezes do total destes poluentes com as misturas mornas. Visualmente também foi constatada uma diminuição expressiva dos fumos de asfalto com a mistura morna em campo. Por fim, estimou-se que há uma economia significativa do consumo de combustíveis com a redução da temperatura de secagem e aquecimento dos agregados em usina com as misturas mornas. Deste modo, o trabalho demonstra, pelas propriedades físicas e mecânicas avaliadas em laboratório e em campo, que a qualidade das misturas asfálticas mornas é similar às das usinadas a quente, com os benefícios da redução das emissões de poluentes e da economia de energia. 


\section{ABSTRACT}

In the last years there has been an increasing concern for the environment. In this context, warm mixes asphalt was developed with positive impact not only on the environmental pollution, but also on the energy consumption, due to the reduction of mixing and compaction temperatures. This work compares the behavior of warm mixes asphalts (with surfactant additive) with similar hot mixes asphalt (conventional ones), through compaction and mechanical properties, as well as additional tests, in laboratory. The results indicate that it is not necessary to change the conventional asphalt mix design for warm mixes, and also that the optimum asphalt content in the warm mixes should be maintained similar to the hot mixes. However, the results are dependent on the asphalt type, the asphalt content, and the level of mixing and compaction temperature reduction. The temperature control and the magnitude of its reduction are essential for the final quality of the warm mix in this technology. Besides, two test tracks were monitored, where there were no additional difficulties during the mixing procedure and in the construction site. The results of the field control and the evaluation of the pavement surface in the warm mix test tracks were similar to the hot mix techniques. Pollutants emissions (priority $\mathrm{PAH}$ on the particulate matter) from warm and hot mixes asphalt mixes were analyzed, in the laboratory, in the mixing plant and in the field, during one of the test tracks construction. The results demonstrated that there was a reduction of about three times on the total amount of these pollutants with the warm mixes. Visually, it was also verified that there was a large reduction of asphalt fumes with the warm mix in the field. Finally, it was estimated that there are significant energy savings when reducing drying and heating temperatures of the aggregates in the mixing plant with warm mixes. Thus, this work shows, through the physical and mechanical properties evaluated in the laboratory and in the field, that the quality of warm mixes is similar to the hot mixes, with the benefits of reducing pollutant emissions and saving energy. 


\section{LISTA DE FIGURAS}

Figura 1 - Classificação das misturas asfálticas em função de temperaturas típicas de usinagem ..... 46

Figura 2 - Esquema de recobrimento do agregado pelo ligante asfáltico em função da elevação de

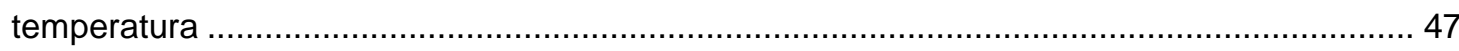

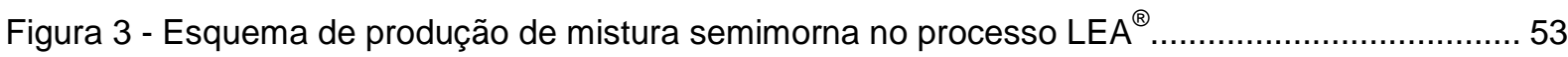

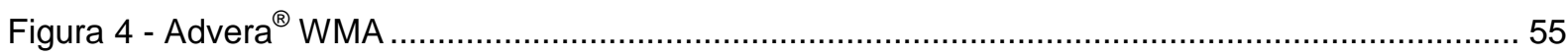

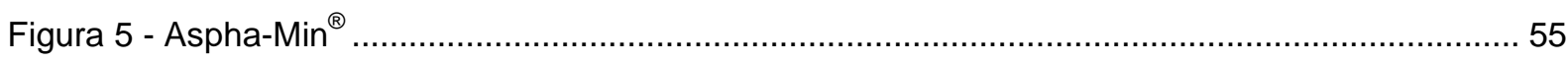

Figura 6 - "Caixa de mistura" para dispersão de zeólitas em usinas contínuas .................................... 56

Figura 7 - Trechos experimentais de misturas a quente e morna, respectivamente com e sem a formação de "bumps"

Figura 8 - Foto térmica da mistura convencional em comparação com a mistura morna Advera ${ }^{\circledR}$ WMA

.

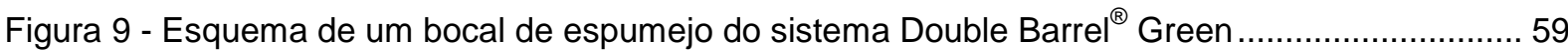

Figura 10 - Sistema Double Barrel ${ }^{\circledR}$ Green instalado em usina ........................................................ 59

Figura 11 - Esquema de produção e aplicação WMA-Foam ${ }^{\circledR}$......................................................... 61

Figura 12 - Esquema de instalação de dispositivos no processo WMA Terex ${ }^{\circledR}$.................................. 63

Figura 13 - Asfalto espumado e após a meia-vida no processo WMA Terex ${ }^{\circledR}$.................................... 64

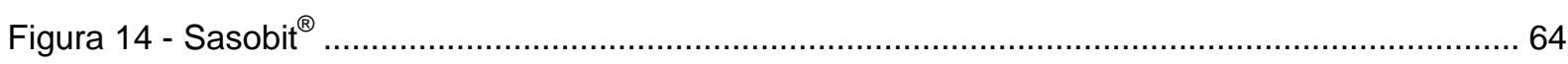

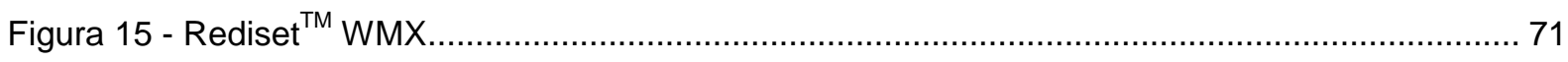

Figura 16 - Variação das emissões de $\mathrm{CO}_{2}$ em função do tipo de agregado .................................... 76

Figura 17 - Esquema de emissões asfálticas durante a usinagem .................................................... 80

Figura 18 - HPAs prioritários, segundo ATSDR e USEPA ............................................................... 82

Figura 19 - Vapores e fumos de asfalto com a aplicação de uma mistura a quente a $150^{\circ} \mathrm{C}$ e de uma

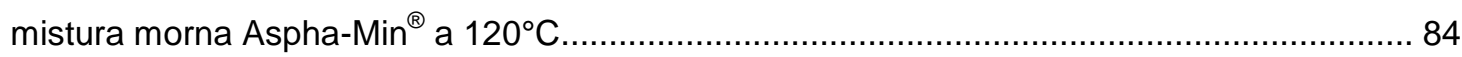

Figura 20 - Instalação de filtro para a medida de exposição ocupacional ao material particulado em obra com misturas a quente e morna no Rio de Janeiro

Figura 21 - Resultados de medidas de exposição ocupacional ao material particulado em obra com mistura morna e mistura a quente no Rio de Janeiro

Figura 22 - Variação anual do preço médio do petróleo no "Basket Price" da OPEP, em dólares

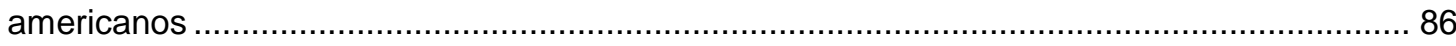

Figura 23 - Consumo de combustível, em usina, sem perdas térmicas e com perdas térmicas ......... 89

Figura 24 - Curva granulométrica - Agregados Pedreira Santa Isabel ............................................. 97

Figura 25 - Curva granulométrica - Agregados Pedreira Serveng Barueri ........................................ 99

Figura 26 - Curva granulométrica - Agregados Pedreira Basalto 6 ............................................... 100

Figura 27 - Curvas granulométricas utilizadas na presente pesquisa ............................................. 101

Figura 28 - Características de consistência dos ligantes asfálticos da presente pesquisa ................ 103

Figura 29 - Mistura de aditivo ao ligante asfáltico - Detalhe do equipamento do LTP/EPUSP ......... 104 
Figura 30 - Curva de viscosidade do CAP 50-70 (Saybolt-Furol) ................................................ 105

Figura 31 - Curva de viscosidade do CAP 30-45 (Brookfield) ……............................................ 106

Figura 32 - Misturadora para usinagem de misturas asfálticas no LTP/EPUSP ….......................... 107

Figura 33 - Parâmetros volumétricos obtidos na dosagem Marshall da HMA1 ................................. 109

Figura 34 - Parâmetros volumétricos obtidos na dosagem Marshall da HMA2 .................................. 111

Figura 35 - Parâmetros volumétricos obtidos na dosagem Marshall da HMA3 …................................ 112

Figura 36 - Parâmetros volumétricos das misturas a quente no teor de projeto ............................... 113

Figura 37 - Compactação na mesa compactadora francesa do LTP/EPUSP ...................................... 116

Figura 38 - Corpo de prova moldado em mesa compactadora (e já testado) e em Marshall ............ 116

Figura 39 - Exemplar de corpo de prova para verificação da compactação em mesa compactadora117

Figura 40 - Curvas granulométricas típicas BBSG, BBTM 10B, faixa C DNIT e gap-graded 3/8"

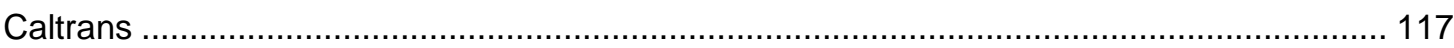

Figura 41 - Compactador giratório, modelo PCG francesa, do LTP/EPUSP ..................................... 118

Figura 42 - Corpo de prova moldado em PCG e em equipamento Marshall..................................... 119

Figura 43 - Ensaio de resistência à tração por compressão diametral no LTP/EPUSP ...................... 120

Figura 44 - Ensaio de módulo de resiliência no LTP/EPUSP .......................................................... 121

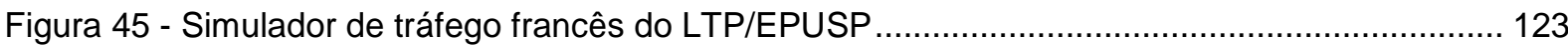

Figura 46 - Leitura de deformações permanentes no simulador de tráfego ........................................ 123

Figura 47 - Etapas do ensaio de dano por umidade induzida (da esquerda para a direita, corpos de prova submetidos a vácuo para saturação parcial, banho térmico, congelamento e resistência à tração) 124

Figura 48 - Resumo esquemático dos ensaios de propriedades mecânicas e testes complementares 125

Figura 49 - Resultados da compactação em compactador Marshall ............................................... 127

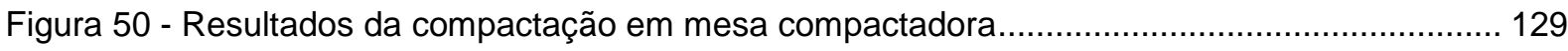

Figura 51 - Evolução da compactação na prensa de cisalhamento giratório ...................................... 131

Figura 52 - Resumo de resultados de compactação em equipamentos Marshall, mesa compactadora

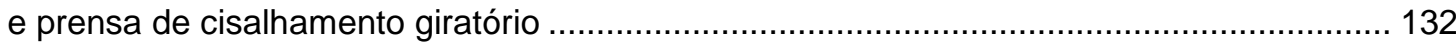

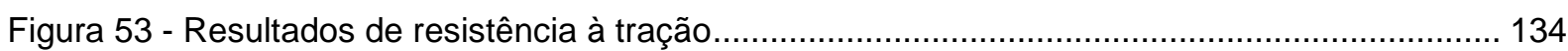

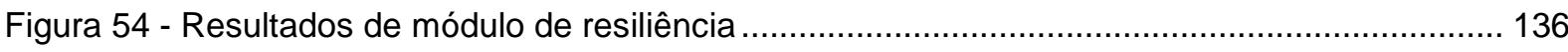

Figura 55 - Resultados de deformação permanente em trilha de roda ......................................... 138

Figura 56 - Localização do trecho experimental na Rodovia Presidente Dutra em Guarulhos, em relação a São Paulo

Figura 57 - Croqui da região onde seria executado o trecho experimental na Rodovia Presidente

Dutra 144

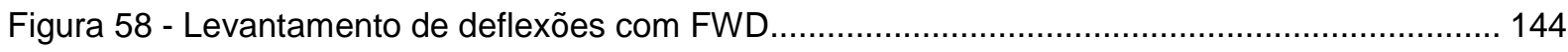

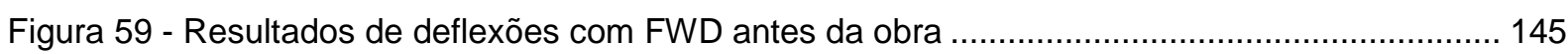

Figura 60 - Levantamento de irregularidade com perfilômetro laser .............................................. 146

Figura 61 - Resultados de QI e IRI antes da obra .................................................................... 147

Figura 62 - Aspecto da mistura morna na vibroacabadora .......................................................... 149 
Figura 63 - Espalhamento da massa asfáltica morna em pista

Figura 64 - Detalhes da compactação com rolos de pneus e metálico .............................................. 149

Figura 65 - Detalhe da segregação da massa asfáltica durante o lançamento em pista .................... 150

Figura 66 - Resumo dos ensaios dos ensaios de propriedades mecânicas e testes complementares com a mistura morna de usina empregada no trecho experimental na Rodovia Presidente Dutra

Figura 67 - Curva granulométrica após extração do ligante e recuperação.....

Figura 68 - Penetração e Ponto de amolecimento médios do asfalto extraído e recuperado, em comparação com o ligante virgem com e sem aditivo

Figura 69 - Viscosidade média do asfalto extraído e recuperado, em comparação com o ligante virgem com e sem aditivo.

Figura 70 - Compactação da mistura morna de usina no compactador Marshall, em comparação com o volume de vazios de corpos de prova de pista e com as misturas de laboratório.

Figura 71 - Compactação da mistura morna de usina em mesa compactadora francesa, em comparação com as misturas de laboratório

Figura 72 - Resistência à tração da mistura morna de usina, em comparação com as misturas de laboratório

Figura 73 - Deformação permanente em trilha de roda da mistura morna de usina, em comparação com as misturas de laboratório 159

Figura 74 - Extração de corpos de prova com sonda rotativa na Rodovia Presidente Dutra..... 161

Figura 75 - Pontos de retirada de corpos de prova na Rodovia Presidente Dutra após a execução do trecho experimental 161

Figura 76 - Resumo dos ensaios laboratoriais com corpos de prova extraídos do trecho experimental na Rodovia Presidente Dutra 162

Figura 77 - Volume de vazios de corpos de prova extraídos do trecho experimental, em comparação com a mistura morna de usina e com as misturas de laboratório

Figura 78 - Resistência à tração de corpos de prova extraídos do trecho experimental, em comparação com a mistura morna de usina e com as misturas de laboratório

Figura 79 - Módulo de resiliência de corpos de prova extraídos do trecho experimental, em comparação com as misturas de laboratório 165

Figura 80 - Resumo dos ensaios em pista no trecho experimental da Rodovia Presidente Dutra .... 166

Figura 81 - Levantamento de macrotextura e microtextura com mancha de areia e pêndulo britânico

Figura 82 - Altura de mancha de areia após três meses da execução do trecho experimental......... 168

Figura 83 - Valor de resistência à derrapagem por pêndulo britânico após três meses da execução do

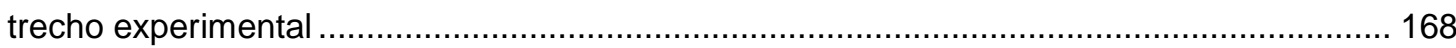

Figura 84 - Resultado de QI e IRI antes e após sete meses da execução do trecho experimental... 169

Figura 85 - Levantamento de deflexões com viga Benkelman no trecho experimental 170

Figura 86 - Resultado de levantamento de deflexões com viga Benkelman após três meses e depois de oito meses da execução do trecho experimental 
Figura 87 - Resultado de levantamento de deflexões com viga Benkelman antes e após oito meses da execução do trecho experimental

Figura 88 - Croqui dos trechos experimentais acompanhados nesta pesquisa na Rodovia dos

Bandeirantes (distâncias aproximadas)

Figura 89 - Localização do trecho experimental na Rodovia dos Bandeirantes em Campinas, em relação a São Paulo 173

Figura 90 - Incorporação do aditivo para mistura morna à carreta de asfalto 175

Figura 91 - Aspecto, no caminhão, da mistura morna usinada para o trecho experimental da Rodovia dos Bandeirantes 176

Figura 92 - Espalhamento da mistura morna em pista na Rodovia dos Bandeirantes. 176

Figura 93 - Compactação da mistura morna em pista na Rodovia dos Bandeirantes 176

Figura 94 - Trecho experimental de mistura morna já executado na Rodovia dos Bandeirantes. 177

Figura 95 - Resumo dos ensaios dos ensaios de propriedades mecânicas e testes complementares com as misturas a quente e morna de usina empregadas no trecho experimental da Rodovia dos Bandeirantes 178

Figura 96 - Forno de extração de betume do laboratório da Basalto 6/Estrutural. 179

Figura 97 - Aparência dos agregados recuperados pelo método Abson, com partículas aderidas (à

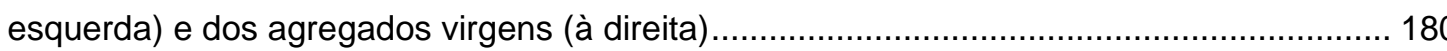

Figura 98 - Curva granulométrica após extração de ligante e recuperação. 181

Figura 99 - Compactação Marshall das misturas a quente e morna de usina, em comparação com os corpos de prova extraídos de pista e com as misturas de laboratório 182

Figura 100 - Compactação em mesa compactadora com as misturas a quente e morna de usina, em comparação com as misturas de laboratório 184

Figura 101 - Evolução da compactação na prensa de cisalhamento giratório das misturas a quente e morna preparadas em usina, em comparação com as misturas de laboratório 185

Figura 102 - Resistência à tração das misturas a quente e morna de usina, em comparação com as misturas de laboratório 186

Figura 103 - Módulo de resiliência das misturas a quente e morna de usina, em comparação com as misturas preparadas em laboratório

Figura 104 - Deformação permanente em trilha de roda das misturas a quente e morna de usina, em comparação com as misturas de laboratório

Figura 105 - Aparência superficial dos revestimentos asfálticos dos trechos experimentais de mistura a quente e morna logo após a obra 191

Figura 106 - Altura de mancha de areia no trecho experimental de mistura a quente 192

Figura 107 - Valor de resistência à derrapagem por pêndulo britânico no trecho experimental de mistura a quente

Figura 108 - Bomba de vácuo utilizada no estudo de emissões de material particulado 195

Figura 109 - Filtro de fibra de quartzo e holder empregados no estudo de emissões de material particulado

Figura 110 - Misturadora fechada e seu sistema de amostragem de emissões no LTP/EPUSP ...... 196 
Figura 111 - Tubo adsorvente usado no estudo de emissões de compostos voláteis e sistema simultâneo de amostragem de emissões de voláteis e de material particulado durante usinagem em misturadora fechada do LTP/EPUSP

Figura 112 - Aparato para amostragem de emissões de material particulado na misturadora do LTP/EPUSP

Figura 113 - Amostragem de emissões em usina de asfalto

Figura 114 - Diferença de fumos asfálticos liberados pela mistura a quente e pela mistura morna quando da abertura do pugmill.

Figura 115 - Amostragem de emissões em pista, durante a execução do trecho experimental da Rodovia dos Bandeirantes

Figura 116 - Diferença de fumos asfálticos liberados pela mistura a quente e pela mistura morna quando da aplicação do material em pista.

Figura 117 - Extração em equipamento Soxhlet no IQ/USP 200

Figura 118 - Fracionamento do extrato orgânico no IQ/USP 201

Figura 119 - Resumo esquemático das amostragens realizadas para a determinação dos HPAs em material particulado das emissões asfálticas

Figura 120 - Concentração de HPAs durante a usinagem das misturas asfálticas no LTP/EPUSP.. 203

Figura 121 - Forno para geração e coleta de fumos de asfalto, utilizado por Cravo et al. (2010) ..... 205

Figura 122 - Concentração de HPAs, logo abaixo do pugmill da usina de asfalto, durante o carregamento do caminhão com mistura a quente

Figura 123 - Concentração de HPAs no espalhamento da mistura asfáltica em pista 


\section{LISTA DE TABELAS}

Tabela 1 - Propriedades físicas do Cecabase $\mathrm{RT}^{\circledR}$ e do Gemul XT14 ….......................................... 67

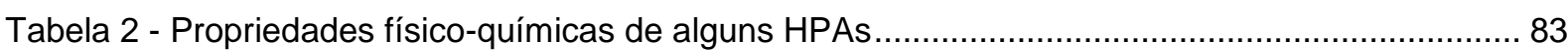

Tabela 3 - Comparativo de economia de energia e gastos com quatro tipos de mistura morna ......... 90

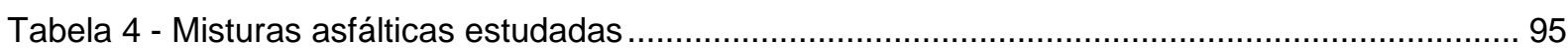

Tabela 5 - Caracterização dos agregados - Pedreira Santa Isabel .................................................. 96

Tabela 6 - Distribuição granulométrica dos agregados e da mistura final para as misturas asfálticas

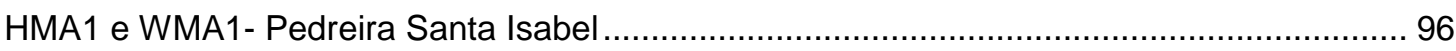

Tabela 7 - Caracterização dos agregados - Pedreira Serveng Barueri ............................................. 98

Tabela 8 - Distribuição granulométrica dos agregados e da mistura final para as misturas asfálticas

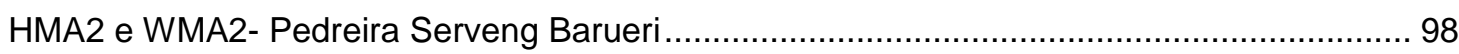

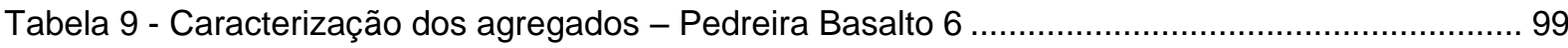

Tabela 10 - Distribuição granulométrica dos agregados e da mistura final para as misturas asfálticas

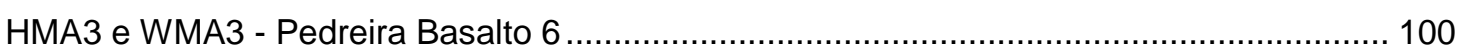

Tabela 11 - Caracterização do ligante asfáltico CAP 50-70 para as misturas asfálticas HMA1 e WMA1 102

Tabela 12 - Caracterização do ligante asfáltico CAP 30-45 para as misturas asfálticas HMA2 e WMA2 102

Tabela 13 - Caracterização do asfalto-borracha para as misturas asfálticas HMA3 e WMA3 ............ 103

Tabela 14 - Consistência dos CAPs 50-70 e 30-45 com e sem surfactante .................................... 105

Tabela 15 - Temperaturas de usinagem e compactação ................................................................. 106

Tabela 16 - Parâmetros volumétricos do teor de projeto ("ótimo") da HMA1 ...................................... 109

Tabela 17 - Parâmetros volumétricos do teor de projeto ("ótimo") da HMA2 …................................ 111

Tabela 18 - Parâmetros volumétricos do teor de projeto ("ótimo") da HMA3 .................................... 113

Tabela 19 - Análise de variância da compactação Marshall............................................................... 127

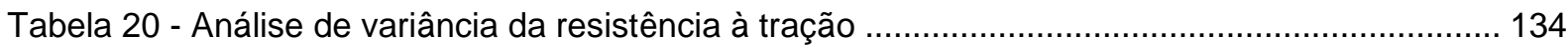

Tabela 21 - Análise de variância do volume de vazios na resistência à tração .................................. 134

Tabela 22 - Análise de variância do módulo de resiliência ............................................................ 136

Tabela 23 - Análise de variância do volume de vazios no módulo de resiliência ................................ 136

Tabela 24 - Resultados do ensaio de dano por umidade induzida ................................................... 140

Tabela 25 - Análise de variância da resistência à tração e volume de vazios no ensaio de dano por

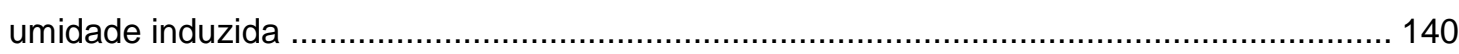

Tabela 26 - Classificação da irregularidade longitudinal em função do QI e do IRI ........................... 146

Tabela 27 - Traço e temperaturas indicados para a produção da mistura morna do trecho experimental da Rodovia Presidente Dutra.

Tabela 28 - Controle de compactação e espessura após a obra do trecho experimental na Rodovia

Presidente Dutra. 
Tabela 29 - Resultados do ensaio de dano por umidade induzida da mistura morna usina, em comparação com as misturas de laboratório

Tabela 30 - Análise de variância da resistência à tração e volume de vazios da mistura morna de usina, em comparação com as misturas de laboratório, para o ensaio de dano por umidade induzida

Tabela 31 - Classificação da macrotextura em função da altura de mancha de areia 167

Tabela 32 - Classificação da microtextura em função do valor de resistência à derrapagem por pêndulo britânico

Tabela 33 - Traço e temperaturas indicados para a produção e aplicação das misturas asfálticas dos trechos experimentais da Rodovia dos Bandeirantes

Tabela 34 - Controle de compactação e espessura dos trechos experimentais na Rodovia dos Bandeirantes.

Tabela 35 - Análise de variância do volume de vazios das misturas a quente e morna relativas aos trechos experimentais da Rodovia dos Bandeirantes

Tabela 36 - Resultados do ensaio de dano por umidade induzida das misturas a quente e morna de usina

Tabela 37 - Análise de variância da resistência à tração e volume de vazios com misturas a quente e morna de usina

Tabela 38 - Parâmetros adotados para o cálculo da economia de energia 211

Tabela 39 - Estimativa de energia necessária para secar/vaporizar a água/aquecer os agregados na usinagem de 160 t mistura morna do trecho experimental da Rodovia Presidente Dutra e de uma mistura a quente

Tabela 40 - Estimativa de energia necessária para secar/vaporizar a água/aquecer os agregados na usinagem de $450 \mathrm{t}$ de misturas morna e quente do trecho experimental da Rodovia dos Bandeirantes. 


\section{LISTA DE ABREVIATURAS E SIGLAS}

\begin{tabular}{|c|c|}
\hline AASHTO & American Association of State Highway and Transportation Officials \\
\hline$A B$ & Asfalto-Borracha \\
\hline ACGIH & American Conference of Governmental and Industrial Hygienists \\
\hline ANOVA & Análise de Variância \\
\hline ANP & Agência Nacional do Petróleo, Gás Natural e Biocombustíveis \\
\hline ANTT & Agência Nacional de Transportes Terrestres \\
\hline APA & Asphalt Pavement Analyzer \\
\hline ARTESP & Agência de Transporte do Estado de São Paulo \\
\hline ASTM & American Society for Testing And Materials \\
\hline ATSDR & Agency for Toxic Substances \& Disease Registry \\
\hline BBSG & Béton Bitumineux Semi-Grenu \\
\hline BBTM & Béton Bitumineux Très Mince \\
\hline BPF & (óleo combustível) Baixo Ponto de Fluidez \\
\hline CALTRANS & California Department of Transportation \\
\hline CAP & Cimento Asfáltico de Petróleo \\
\hline CEDEX & Centro de Estudios y Experimentación de Obras Públicas (de España) \\
\hline CENPES/Petrobras & $\begin{array}{l}\text { Centro de Pesquisas e Desenvolvimento Leopoldo Américo Miguez de } \\
\text { Mello/Petrobras }\end{array}$ \\
\hline CER & Certificados de Emissões Reduzidas \\
\hline CETESB & Companhia Ambiental do Estado de São Paulo \\
\hline CGEE & Centro de Gestão e Estudos Estratégicos \\
\hline $\mathrm{CH}-\mathrm{I}$ & Cal Hidratada (tipo) I \\
\hline CONAMA & Conselho Nacional do Meio Ambiente \\
\hline COPPE-UFRJ & $\begin{array}{l}\text { Coordenação dos Programas de Pós-Graduação de Engenharia da Universidade } \\
\text { Federal do Rio de Janeiro }\end{array}$ \\
\hline COTs & Compostos Orgânicos Totais \\
\hline COVNM & Compostos Orgânicos Voláteis Não Metânicos \\
\hline COVs & Compostos Orgânicos Voláteis \\
\hline CP / CPs & Corpo de Prova / Corpos de Prova \\
\hline CPR & Centro de Pesquisas Rodoviárias da NovaDutra \\
\hline DAT & Dispersed Asphalt Technology \\
\hline DAV & Deutscher Asphaltverband \\
\hline DERSA & Desenvolvimento Rodoviário S.A. \\
\hline DER-SP & Departamento de Estradas de Rodagem de São Paulo \\
\hline DNER & Departamento Nacional de Estradas de Rodagem \\
\hline DNIT & Departamento Nacional de Infra-Estrutura de Transportes \\
\hline $\mathrm{DP}$ & Desvio Padrão \\
\hline DSR & Dynamic Shear Rheometer (Reômetro de Cisalhamento Dinâmico) \\
\hline $\mathrm{EBE}^{(B)}$ & Enrobé à Basse Énergie \\
\hline $\mathrm{EBT}^{(B)}$ & Enrobé à Basse Temperature \\
\hline ED & Estatisticamente diferente \\
\hline EEA & European Environment Agency \\
\hline El & Estatisticamente igual \\
\hline EME & Enrobé à Module Elevé \\
\hline EM & European Standard (do European Committee for Standardization) \\
\hline ES & Especificação de Serviço \\
\hline ESTP & Ecole Spéciale des Travaux Publics \\
\hline ET & Emulsion Technology \\
\hline FBMC & Fórum Brasileiro de Mudanças Climáticas \\
\hline FHWA & Federal Highway Administration \\
\hline FWD & Falling Weight Deflectometer \\
\hline GC-FID & Gas Chromatography with Flame Ionization Detection \\
\hline GEE & Gases de Efeito Estufa \\
\hline GLP & Gás Liquefeito de Petróleo \\
\hline HHS & (US Department of) Health \\
\hline
\end{tabular}




HMA
HPA(s)
HS
HVS
HWMA
IARC
IPCC
IQ/USP
IRI
LAPAV/UFRGS
LCPC
LEA
LPC
LTP/EPUSP

LVDT
MDL
ME
MEA
MEMT
MEPDG
MR
NBR
NCAT
NCHRP
ND
NF
NIOSH
NLT
OPEP
P
P/G
PCG
PG
PTS
QI
RBV
RDT
REL
RRT
RT
RTC
RTFOT
RTnC
SBS
SETRA
SMA
SMS
SR
SUPERPAVE
TMN
TP
UNFCCC
USEPA
USP
VAM
VDM
VRD
VV
VVC

Hot Mix(es) Asphalt

Hidrocarboneto(s) Policíclico(s) Aromático(s)

altura média de mancha de areia

Heavy Vehicle Simulator

Half-Warm Mixes Asphalt

International Regulatory Agency for Research on Cancer

Intergovernmental Panel on Climate Change

Instituto de Química da USP

International Roughness Index

Laboratório de Pavimentação da Universidade Federal do Rio Grande do Sul

Laboratoire Central des Ponts et Chaussées

Low Energy Asphalt

Laboratoire des Ponts et Chaussées

Laboratório de Tecnologia de Pavimentação da Escola Politécnica da

Universidade de São Paulo

Linear Variable Differential Transducers

Mecanismo de Desenvolvimento Limpo

Método de Ensaio

Massa Específica Aparente (da mistura asfáltica compactada)

Massa Específica Máxima Teórica

Mechanistic-Empirical Pavement Design Guide

Módulo de Resiliência

Norma Brasileira

National Center for Asphalt Technology

National Cooperative Highway Research Program

Não Detectável

Norme Française

National Institute for Occupational Safety and Health

Norma del Laboratorio de Transporte de España

Organização dos Países Exportadores de Petróleo

Particulada

Particulada e Gasosa

Presse à Cisaillement Giratoire ou Prensa de Cisalhamento Giratório

Performance Graded

Partículas Totais em Suspensão

Quociente de Irregularidade

Relação Betume x Vazios

Recursos de Desenvolvimento Tecnológico

Recommended Exposure Limit

Resistência Retida à Tração

Resistência à Tração (por Compressão Diametral)

Resistência à tração média dos CPs condicionados à água

Rolling Thin Film Oven Test

Resistência à tração média dos CPs não condicionados à água

(polímero) estireno-butadieno-estireno

Service d'Etudes Techniques des Routes et Autoroutes

Stone Matrix Asphalt

(Comissão de) Saúde, Meio Ambiente e Segurança (do IBP)

Sem Referência

Superior Performing Asphalt Pavements

Tamanho Máximo Nominal

Teor (de ligante asfáltico) de projeto

United Nations Framework Convention on Climate Change

United States Environmental Protection Agency

Universidade de São Paulo

Vazios do Agregado Mineral

Volume Diário Médio

Valor de Resistência à Derrapagem

Volume de Vazios

Volume de vazios dos CPs condicionados à água 
Volume de vazios dos CPs não condicionados à água

WMA TWG Warm Mix(es) Asphalt

Warm Mix Asphalt Technical Working Group 


\section{LISTA DE SÍMBOLOS}

\begin{tabular}{|c|c|}
\hline$\sim$ & aproximadamente \\
\hline${ }^{\circ} \mathrm{C}$ & grau Celsius \\
\hline${ }^{\circ} \mathrm{C} / \mathrm{min}$ & grau Celsius por minuto \\
\hline Ace & acenafteno \\
\hline$B[a] A n$ & benzo[a]antraceno \\
\hline $\mathrm{B}[\mathrm{a}] \mathrm{Py}$ & benzo[a]pireno \\
\hline $\mathrm{B}[\mathrm{b}] \mathrm{F}$ & benzo[b]fluoranteno \\
\hline $\mathrm{B}[\mathrm{e}] \mathrm{Py}$ & benzo[e]pireno \\
\hline$B[g, h, i] P$ & benzo[g,h,i]perileno \\
\hline $\mathrm{B}[\mathrm{k}] \mathrm{F}$ & benzo[k]fluoranteno \\
\hline $\mathrm{C}_{\mathrm{a}}$ & calor específico da água \\
\hline $\mathrm{C}_{\mathrm{agr}}$ & calor específico dos agregados \\
\hline $\mathrm{CH}_{4}$ & metano \\
\hline $\mathrm{CH}_{4}$ & metano \\
\hline Chry & criseno \\
\hline clv & calor latente de vaporização da água \\
\hline $\mathrm{cm}$ & centímetro \\
\hline $\mathrm{C}_{\mathrm{m}}$ & calor específico do material \\
\hline $\mathrm{CO}$ & monóxido de carbono \\
\hline $\mathrm{CO}_{2}$ & dióxido de carbono \\
\hline $\mathrm{CO}_{2} / \mathrm{MWh}$ & dióxido de carbono por megawatt-hora \\
\hline cont $/ \mathrm{km}$ & contagem/quilômetro \\
\hline $\mathrm{cP}$ & centipoise \\
\hline $\mathrm{C}_{\mathrm{v}}$ & calor específico de vapor \\
\hline $\mathrm{DB}[\mathrm{a}, \mathrm{h}] \mathrm{A}$ & dibenzo[a,h]antraceno \\
\hline $\mathrm{FI}$ & fluoranteno \\
\hline Flu & fluoreno \\
\hline g & grama \\
\hline $\mathrm{g} / \mathrm{cm}^{3}$ & grama por centímetro cúbico \\
\hline $\mathrm{g} / \mathrm{mol}$ & grama por mol \\
\hline $\mathrm{h}$ & hora \\
\hline HFCs & hidrofluorocarbonos \\
\hline $\mathrm{Hz}$ & hertz \\
\hline i.e. & do Latim id est (isto é) \\
\hline Ipy & indeno[1,2,3-cd]pireno \\
\hline J & joule \\
\hline $\mathrm{J} / \mathrm{kg}$ & joule por quilo \\
\hline $\mathrm{J} / \mathrm{kg} /{ }^{\circ} \mathrm{C}$ & joule por quilo por grau Celsius \\
\hline $\mathrm{kg}$ & quilo \\
\hline kg/MWh & quilo por megawatt-hora \\
\hline $\mathrm{kg} / \mathrm{t}$ & quilo por tonelada \\
\hline kJ & quilojoule \\
\hline $\mathrm{km}$ & quilômetro \\
\hline $\mathrm{km} / \mathrm{h}$ & quilômetro por hora \\
\hline $\mathrm{kN}$ & quilonewton \\
\hline L & litro \\
\hline $\mathrm{L} / \mathrm{min}$ & litro por minuto \\
\hline $\mathrm{m}$ & metro \\
\hline $\mathrm{m} / \mathrm{km}$ & metro por quilômetro \\
\hline $\mathrm{m}^{2}$ & metro quadrado \\
\hline $\mathrm{m}_{\mathrm{agr}}$ & massa dos agregados \\
\hline $\mathrm{mg} / \mathrm{kg}$ & miligrama por quilo \\
\hline $\mathrm{mg} / \mathrm{m}^{3}$ & miligrama por metro cúbico \\
\hline $\min$ & minuto \\
\hline
\end{tabular}




$\begin{array}{ll}\mathrm{MJ} / \mathrm{t} & \text { megajoule por tonelada } \\ \mathrm{mL} & \text { mililitro } \\ \mathrm{mm} & \text { milímetro } \\ \mathrm{m}_{\mathrm{m}} & \text { massa do material } \\ \mathrm{MPa} & \text { megapascal } \\ \mathrm{N} & \text { newton } \\ \mathrm{N}_{2} & \text { nitrogênio } \\ \mathrm{N}_{2} \mathrm{O} & \text { óxido nitroso } \\ \mathrm{Na} & \text { antraceno } \\ \mathrm{ng} / \mathrm{g} & \text { nanograma por grama } \\ \mathrm{NO}_{2}, \mathrm{NO}_{x}, \mathrm{~N}_{2} \mathrm{O} & \text { óxidos nítrico e nitrosos } \\ \mathrm{Pa} & \text { pascal } \\ \mathrm{Pa} \cdot \mathrm{s} & \text { pascal-segundo } \\ \mathrm{PFCs} & \text { perfluorocarbonos } \\ \mathrm{Phe} & \text { fenantreno } \\ \mathrm{Py} & \text { pireno } \\ \mathrm{Q} & \text { energia } \\ \mathrm{R} \$ & \text { reais } \\ \mathrm{S} & \text { segundo } \\ \mathrm{SF} & \text { hexafluoreto de enxofre } \\ \mathrm{SO} & \text { dióxido sulfúrico } \\ \mathrm{sSF} & \text { segundo Saybolt-Furol } \\ \mathrm{t} & \text { tonelada } \\ \mathrm{t}_{\mathrm{agr}} & \text { temperatura de aquecimento dos agregados } \\ \mathrm{t}_{\mathrm{amb}} & \text { temperatura ambiente } \\ \mathrm{U} \$ & \text { dólar americano } \\ \mathrm{U}_{\mathrm{agr}} & \text { teor de umidade dos agregados } \\ \Delta \theta & \text { diferença entre as temperaturas ambiente e de mistura } \\ \Delta \mathrm{m}_{\mathrm{v}} & \text { diferença de massas de vapor inicial e final } \\ \mu \mathrm{L} & \text { microlitro } \\ \mu \mathrm{m} & \text { micrômetro } \\ & \end{array}$




\section{SUMÁRIO}

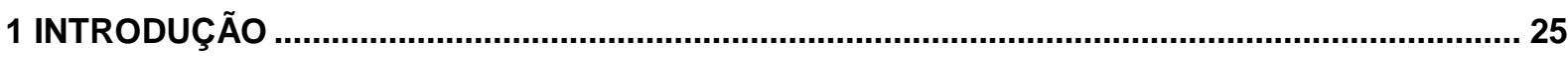

1.1 OBJETIVOS

1.2 METODOLOGIA

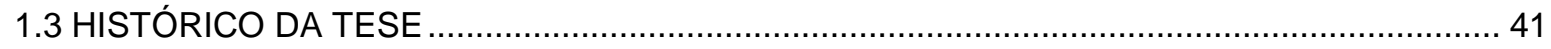

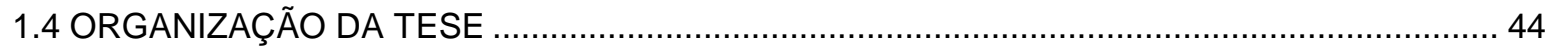

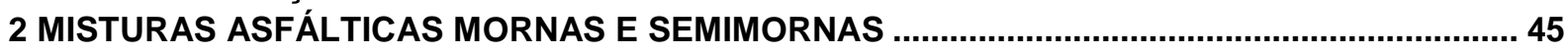

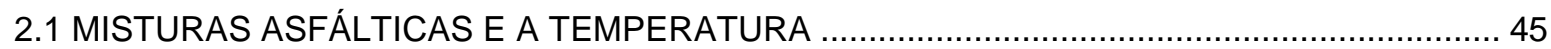

2.2 PRODUÇÃO DE MISTURAS ASFÁLTICAS MORNAS E SEMIMORNAS ................................ 48

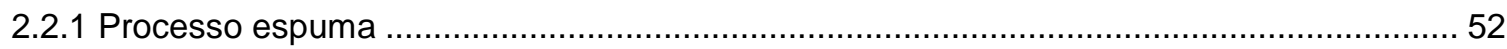

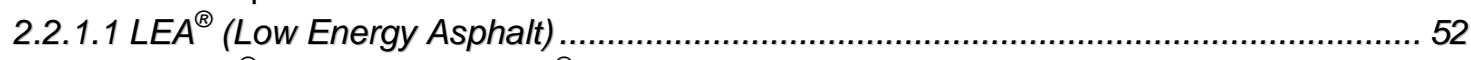

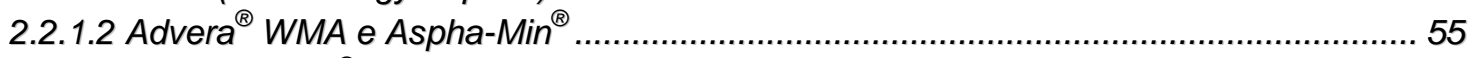

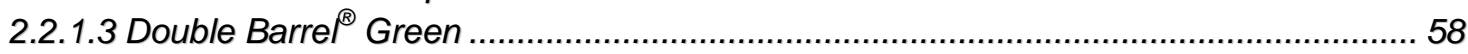

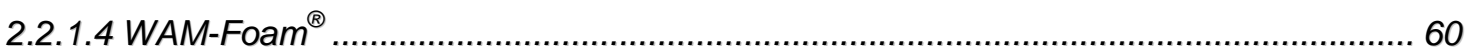

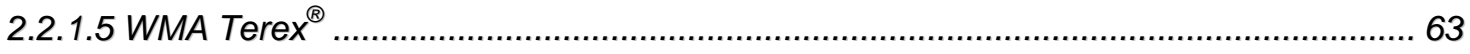

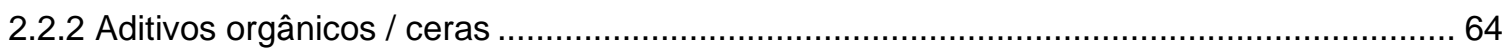

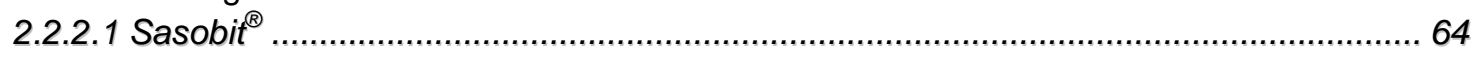

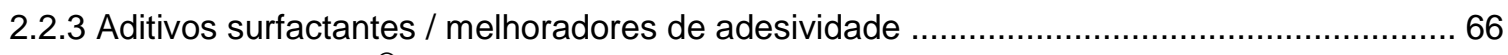

2.2.3.1 Cecabase $R T^{\circledast}$ / Gemul XT14

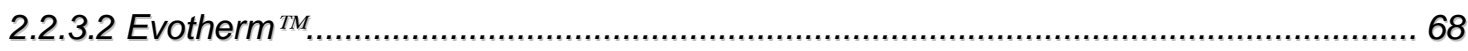

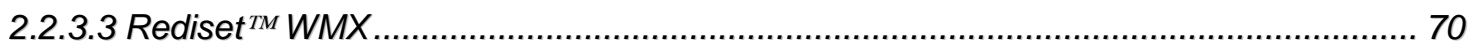

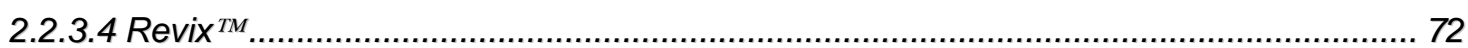

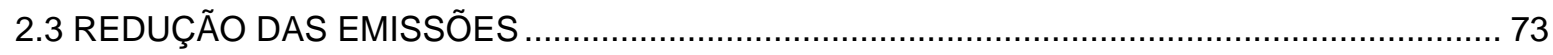

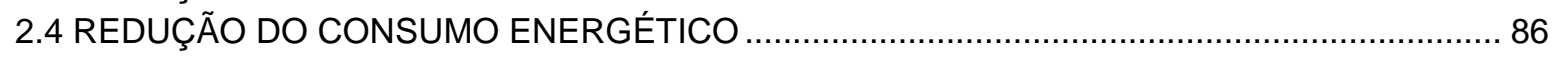

2.5 ALGUNS ESTUDOS BRASILEIROS COM MISTURAS ASFÁLTICAS MORNAS E

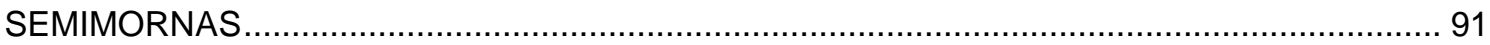

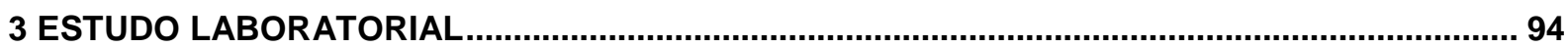

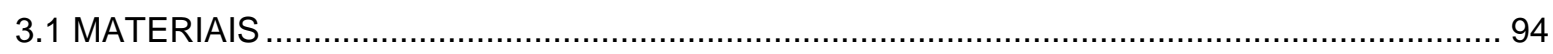

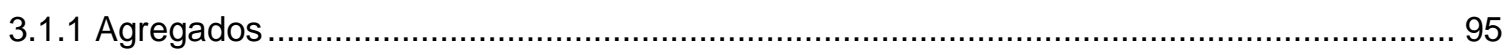

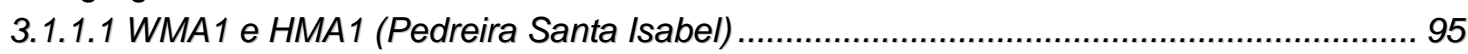

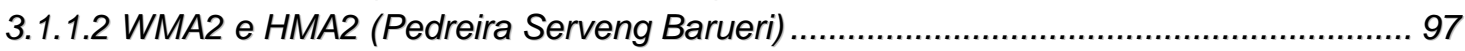

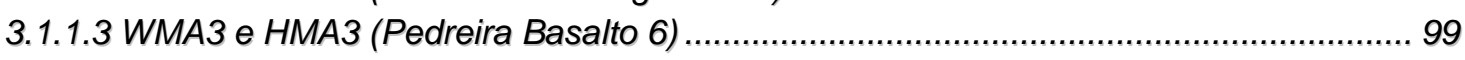

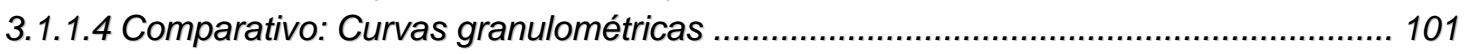

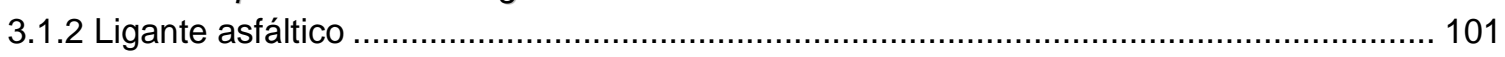

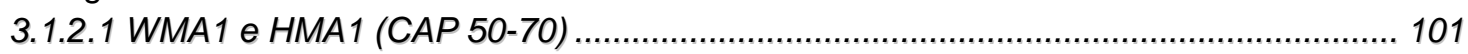

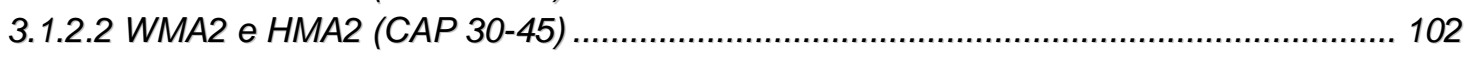

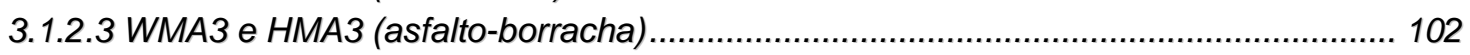

3.1.2.4 Comparativo: Consistência dos ligantes asfálticos.................................................. 103

3.1.3 Aditivo para mistura morna e consistência do ligante asfáltico com o produto ................... 104

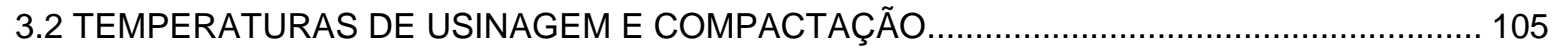

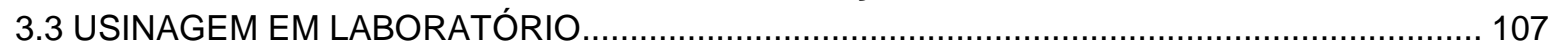

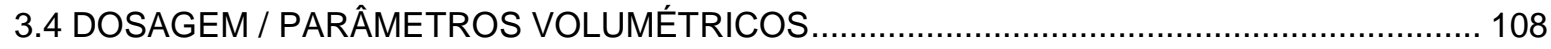

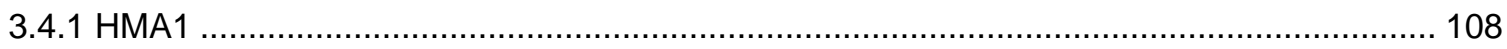

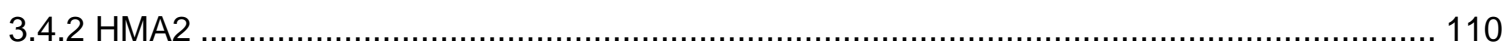

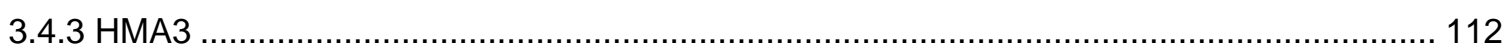

3.4.4 Comparativo: Dosagem / Parâmetros volumétricos .................................................... 113

3.5 ENSAIOS DE PROPRIEDADES MECÂNICAS E TESTES COMPLEMENTARES ................. 114

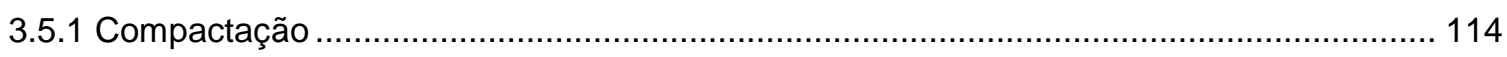


3.5.1.1 Marshall

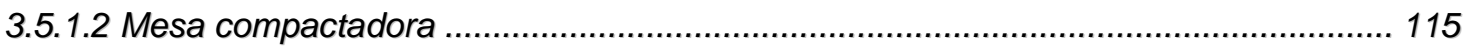

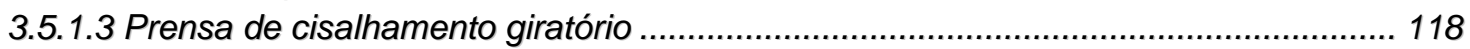

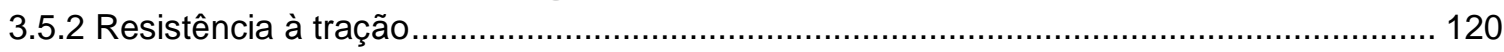

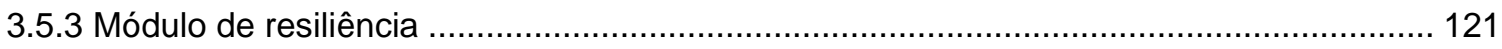

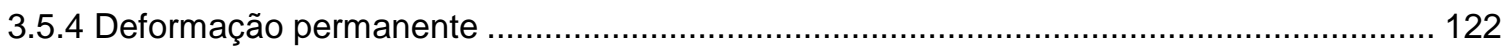

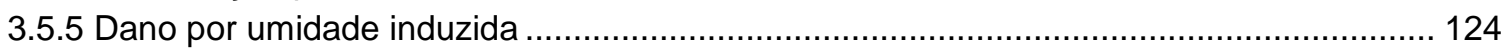

3.5.7 Resumo esquemático dos ensaios de propriedades mecânicas e testes complementares

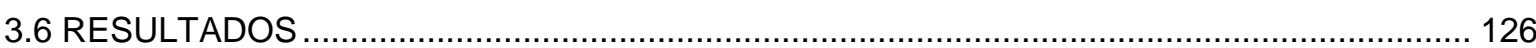

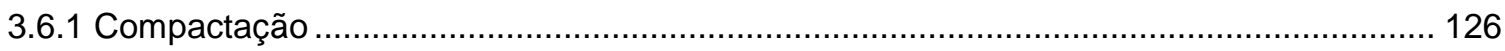

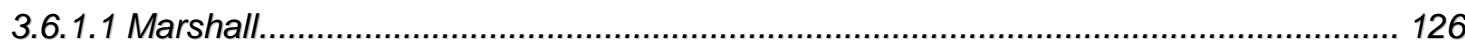

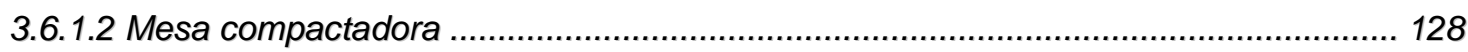

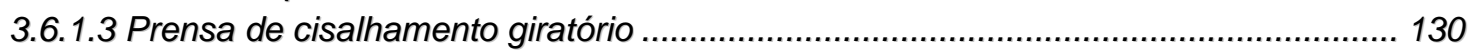

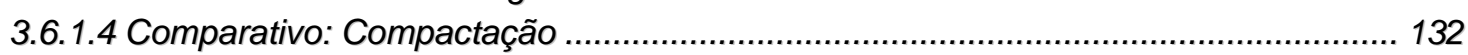

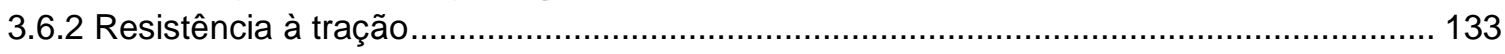

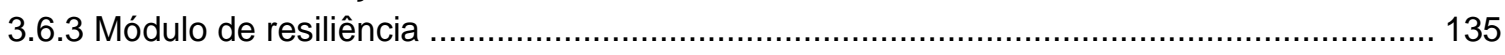

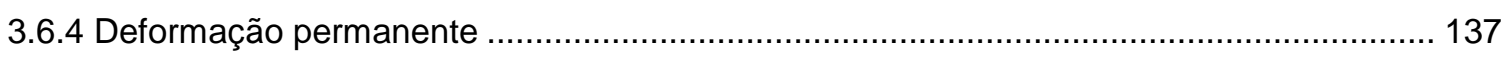

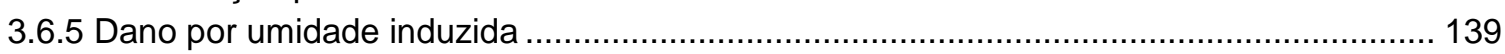

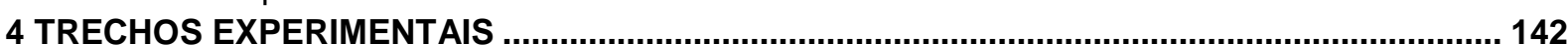

4.1 TRECHO EXPERIMENTAL COM MISTURA MORNA NA RODOVIA PRESIDENTE DUTRA 142

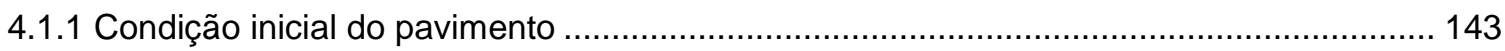

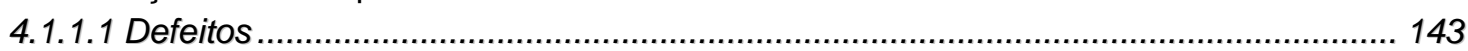

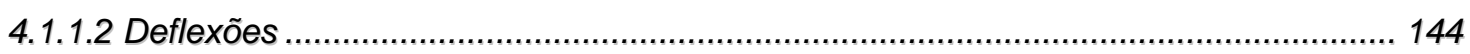

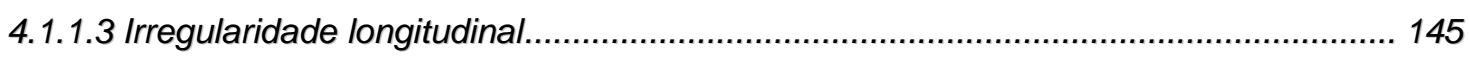

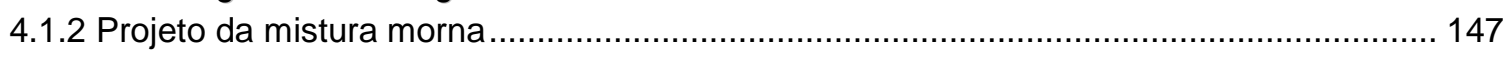

4.1.3 Produção em usina e aplicação da mistura morna em pista ........................................... 148

4.1.4 Controle tecnológico de compactação e espessura ....................................................... 150

4.1.5 Ensaios laboratoriais de propriedades mecânicas e testes complementares com a mistura

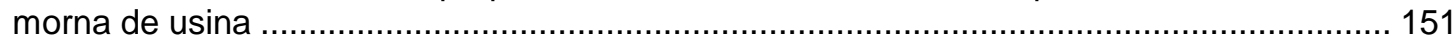

4.1.5.1 Características dos materiais da mistura morna de usina e de seu ligante asfáltico. 152

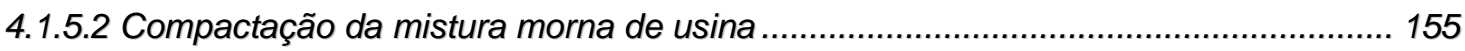

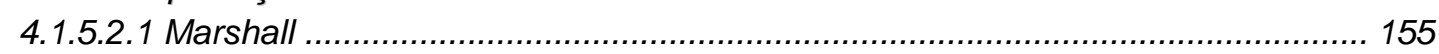

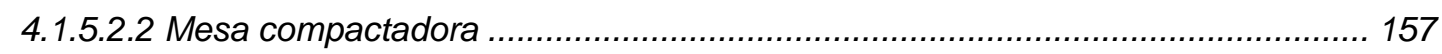

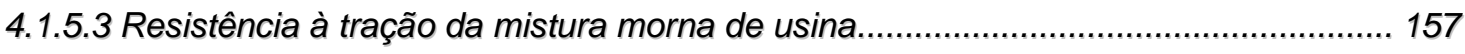

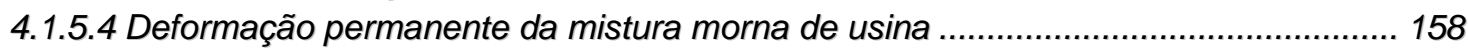

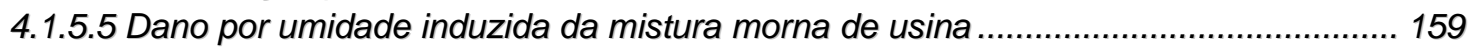

4.1.6 Verificação de volume de vazios e ensaios de propriedades mecânicas com corpos de

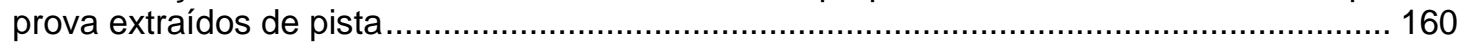

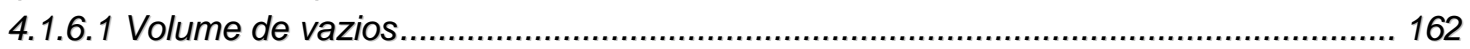

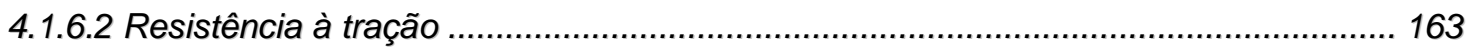

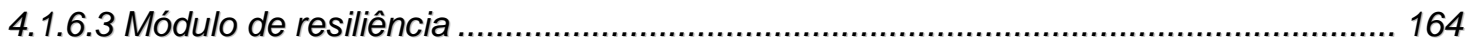

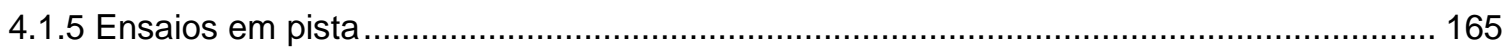

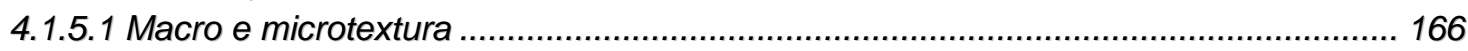

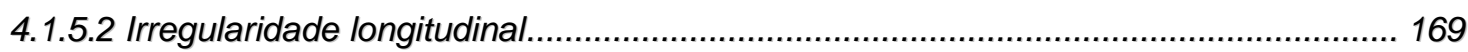

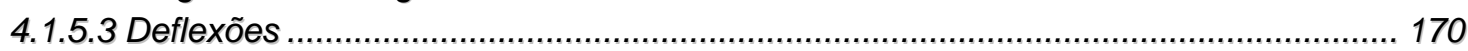

4.2 TRECHO EXPERIMENTAL COM MISTURAS MORNA E A QUENTE NA RODOVIA DOS

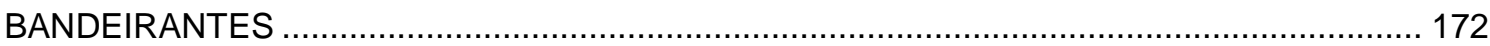

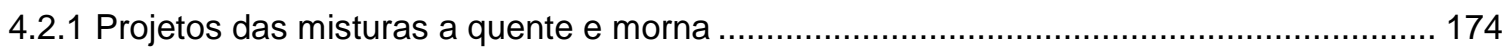

4.2.2 Produção em usina e aplicação das misturas a quente e morna em pista ........................ 175

4.2.3 Controle tecnológico de compactação e espessura .......................................................... 177 
4.2.4 Ensaios laboratoriais de propriedades mecânicas e testes complementares com as misturas a quente e morna de usina.

4.2.4.1 Características dos materiais das misturas a quente e morna de usina ..................... 179

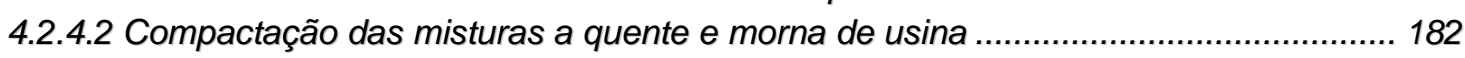

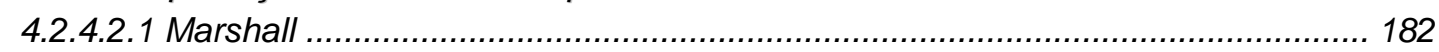

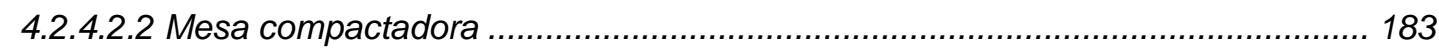

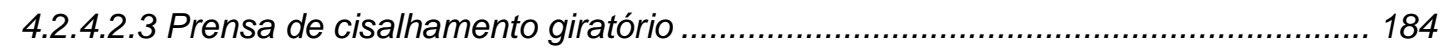

4.2.4.3 Resistência à tração das misturas a quente e morna de usina.................................. 186

4.2.4.4 Módulo de resiliência das misturas a quente e morna de usina.................................. 187

4.2.4.5 Deformação permanente das misturas a quente e morna de usina............................ 188

4.2.4.6 Dano por umidade induzida das misturas a quente e morna de usina ........................ 190

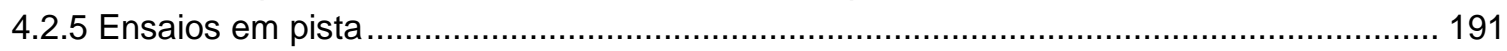

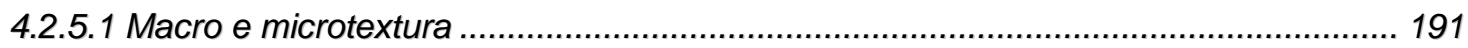

5 REDUÇÃO DA EMISSÃO DE POLUENTES E DO CONSUMO ENERGÉTICO ........................... 194

5.1 REDUÇÃO DA EMISSÃO DE POLUENTES: CONCENTRAÇÃO DE HIDROCARBONETOS POLICÍCLICOS AROMÁTICOS NA PRODUÇÃO E NA APLICAÇÃO DAS MISTURAS

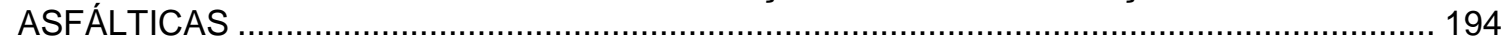

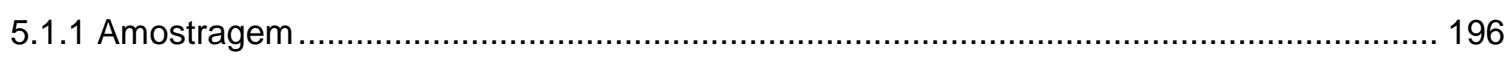

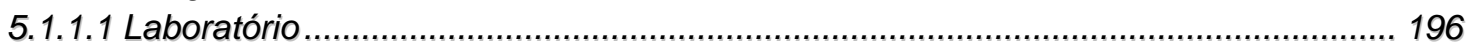

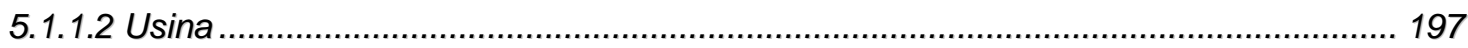

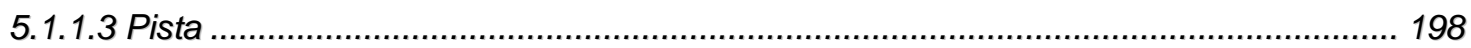

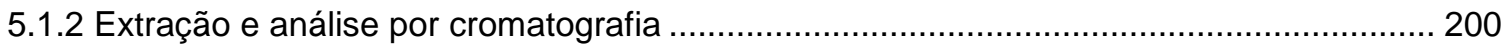

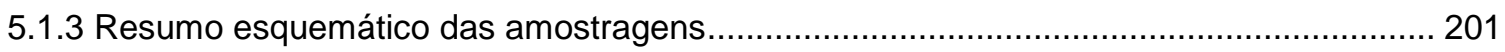

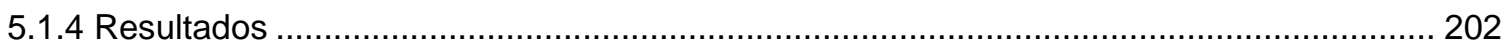

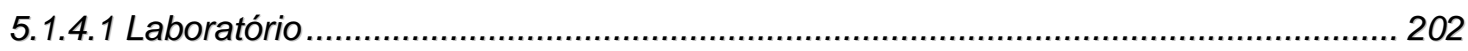

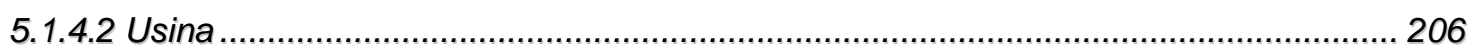

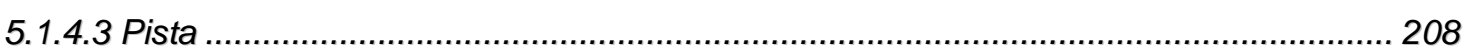

5.2 REDUÇÃO DO CONSUMO ENERGÉTICO: ESTIMATIVA DA ECONOMIA DE COMBUSTÍVEL

.

5.2.1 Mistura morna do trecho experimental da Rodovia Presidente Dutra ............................. 211

5.2.2 Mistura morna do trecho experimental da Rodovia dos Bandeirantes ............................... 213

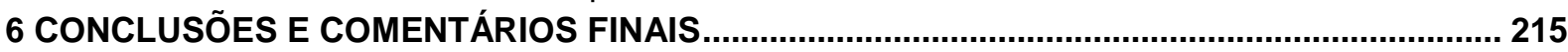

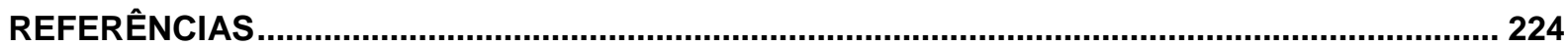




\section{INTRODUÇÃO}

Nos últimos anos a preocupação com o meio ambiente tem sido cada vez mais evidente. Com a adoção do Protocolo de Quioto em 1997, diversos segmentos da sociedade vêm buscando fomentar atividades que contribuam com a redução de emissões de gases de efeito estufa (GEE), uma vez que se acredita que estes elementos sejam os grandes responsáveis pelo aquecimento global.

O setor rodoviário tem procurado seguir esta mesma tendência, desenvolvendo novas tecnologias no âmbito da pavimentação com o objetivo de contribuir com as questões ambientais. Dentro deste contexto, destacam-se dois marcos importantes: a União Europeia começou a buscar formas de cumprir as metas estabelecidas pelo Protocolo de Quioto, e o Ministério do Trabalho e das Relações Sociais alemão passou a considerar limites de exposição para os trabalhadores expostos a fumos de asfalto em 1996. Estes dois fatos principiaram as iniciativas de se produzir misturas asfálticas com temperaturas mais baixas que àquelas usuais a quente para reduzir a emissão de poluentes e o consumo energético (NEWCOMB, 2006; PROWELL e HURLEY, 2007). Surgiram assim, as chamadas misturas asfálticas mornas (em inglês, Warm Mixes Asphalt - WMA), que se referem a um grupo de tecnologias desenvolvidas com o intuito de diminuir a temperatura das misturas asfálticas convencionais em cerca de $30^{\circ} \mathrm{C}$ a $50^{\circ} \mathrm{C}$ (NEWCOMB, 2006; PROWELL e HURLEY, 2007).

O assunto foi primeiramente apresentado em 1997, dentro do German Bitumen Forum (uma parceria entre governo, indústria e trabalhadores da Alemanha), em resposta à consideração do Ministério alemão sobre a exposição ocupacional aos fumos de asfalto (PROWELL e HURLEY, 2007). Depois da criação deste fórum, a DAV (associação alemã de asfalto) iniciou um programa chamado "Low Temperature Asphalt" com o principal objetivo de investigar diversos métodos em que misturas asfálticas pudessem ser produzidas em temperaturas mais baixas que aquelas convencionais a quente (BARTHEL et al., 2004).

Os primeiros pavimentos com misturas asfálticas mornas foram então construídos na Europa (mais especificamente na Alemanha e na Noruega), a partir de 1995, utilizando diferentes tecnologias e, posteriormente, o tema foi introduzido 
nos Estados Unidos em 2002 (PROWELL e HURLEY, 2007). Os norte-americanos, por meio do FHWA (Federal Highway Administration), em conjunto com a AASHTO (American Association of State Highway and Transportation Officials) e a NCHRP (National Cooperative Highway Research Program), ainda fizeram um Scanning Tour à Europa em 2007 com o propósito de coletar informações adicionais sobre as tecnologias de misturas mornas que pudessem auxiliar em sua implementação no país, com particular ênfase no desempenho em longo prazo (PROWELL e HURLEY, 2007; D'ANGELO, et al., 2008).

Seguindo esta mesma tendência, foi ainda desenvolvido na França um outro tipo de tecnologia onde a redução de temperatura é ainda maior, da ordem de $50^{\circ} \mathrm{C}$ ou mais, com as misturas sendo preparadas e aplicadas abaixo de $100^{\circ} \mathrm{C}$. Neste caso, têm-se as chamadas misturas asfálticas semimornas (em inglês, Half-Warm Mixes Asphalt - HWMA).

Atualmente, com a disseminação do uso de misturas com asfaltos modificados com polímero ou com borracha, para uma maior durabilidade dos pavimentos, onde as temperaturas requeridas na usinagem são ainda maiores que aquelas com asfaltos convencionais (em aproximadamente 10 a $20^{\circ} \mathrm{C}$ ), o emprego de misturas asfálticas mornas e semimornas se faz ainda mais pertinente.

A literatura em geral indica que a diminuição das temperaturas de mistura e compactação com as misturas mornas e semimornas pode trazer importantes benefícios relacionados ao meio ambiente, à exposição ocupacional e à qualidade da pavimentação.

\section{$\underline{\text { Benefícios }}$}

Menor emissão de poluentes atmosféricos

As temperaturas mais baixas empregadas na produção de misturas mornas e semimornas geram menores quantidades de poluentes lançados ao ar, não só porque são emitidos menos vapores e fumos de asfalto durante a mistura em usina e a aplicação em campo, mas também porque parte do combustível que seria utilizado na usinagem deixa de ser queimado (PROWELL e HURLEY, 2007).

De modo geral, D'Angelo et al. (2008) apontam alguns resultados obtidos em estudos na Europa em que se verificou uma queda da ordem de 30 a $40 \%$ de gás 
carbônico - $\mathrm{CO}_{2}$ (relacionado aos GEE) e dióxido de enxofre - $\mathrm{SO}_{2}$ (ligado às chuvas ácidas), 50\% de compostos orgânicos voláteis - COVs (precursores do ozônio ${ }^{1} \mathrm{e}$ associados aos Hidrocarbonetos Policíclicos Aromáticos - HPAs), 10 a 30\% de monóxido de carbono - $\mathrm{CO}$ (indicadores de eficiência de queima), 60 a $70 \%$ de óxidos de nitrogênio - $\mathrm{NO}_{x}$ (precursores de ozônio) e 20 a $25 \%$ de materiais particulados.

Dentro deste contexto, a iniciativa de se diminuir as emissões de poluentes poderia então ser inserida em projetos para a obtenção de créditos de carbono, dentro dos mecanismos de flexibilização propostos no Protocolo de Quioto, em projetos inseridos no Mecanismo de Desenvolvimento Limpo (MDL). Assim, a venda de excedentes de créditos de carbono passaria ser um atrativo competitivo para as misturas asfálticas mornas e semimornas (OLARD, 2008).

No mais, a redução das emissões pode encorajar o uso de misturas mornas em áreas densamente povoadas, onde a qualidade do ar é notadamente baixa e a inserção de novas fontes de emissão é extremamente controlada (KRISTJÁNSDÓTTIR et al., 2007).

\section{Melhoria do ambiente de trabalho na pavimentação}

O uso de misturas mornas e semimornas traz benefícios para os trabalhadores da área de pavimentação que são particularmente difíceis de mensurar. Primeiramente, tem-se o fato de que com esta nova técnica os operários ficam menos expostos às emissões asfálticas, sendo este um fator positivo para a sua saúde (NEWCOMB, 2006; BARTHEL et al., 2004; HASSAN, 2009; PROWELL e HURLEY, 2007). O National Institute for Occupational Safety and Health (NIOSH) dos Estados Unidos fez um levantamento de pesquisas que estudaram os efeitos da exposição ocupacional às emissões asfálticas e verificaram que os dados referentes ao potencial carcinogênico dos fumos de asfalto em humanos ainda são limitados. Embora se tenha concluído que tais dados ainda não forneceram evidências

\footnotetext{
${ }^{1}$ De acordo com a European Environment Agency (EEA), os precursores de ozônio são "compostos químicos, como monóxido de carbono $(\mathrm{CO})$, metano $\left(\mathrm{CH}_{4}\right)$, compostos orgânicos voláteis não metânicos (COVNM) e óxidos de nitrogênio $\left(\mathrm{NO}_{x}\right)$, que na presença de radiação solar reagem com outros compostos químicos para formar ozônio, principalmente na troposfera" (http://glossary.eea.europa.eu/EEAGlossary).
} 
consistentes relativas àqueles efeitos nocivos, afirma-se que não se pode excluir o risco carcinogênico destes elementos durante a exposição ocupacional em operações de pavimentação (NIOSH, 2000).

Sabe-se que os produtos asfálticos submetidos a elevadas temperaturas emitem elementos como os $\mathrm{HPAs}^{2}$, em que alguns são suspeitos de serem mutagênicos e/ou carcinogênicos (NIOSH, 2000; RAVINDRA et al., 2008; YASSAA et al., 2001; FERNANDES et al., 2009). Dentro deste contexto, a temperatura é um fator crucial no controle das emissões dos asfaltos (GASTHAUER et al., 2008) e as misturas mornas e semimornas podem contribuir para a redução da exposição ocupacional às emissões de compostos como estes.

$\mathrm{Na}$ Itália, por exemplo, foi realizado um estudo de emissões em usina com uma mistura morna tipo WAM-Foam ${ }^{\circledR}\left(120\right.$ a $\left.125^{\circ} \mathrm{C}\right)$ em comparação com uma mistura a quente $\left(180^{\circ} \mathrm{C}\right)$ e os resultados mostraram que durante a usinagem da mistura morna obteve-se uma redução de emissões da ordem de $35 \%$ de $\mathrm{CO}_{2}, 8 \%$ de $\mathrm{CO}, 60 \%$ de $\mathrm{NO}_{x}$ e 25 a $30 \%$ de $\mathrm{SO}_{2}$ e de material particulado, conforme relatam Lecomte et al. (2007). Já na França observou-se que as emissões em usina com uma mistura morna tipo Aspha-Min ${ }^{\circledR}\left(130^{\circ} \mathrm{C}\right)$ em comparação com uma mistura a quente $\left(160^{\circ} \mathrm{C}\right)$ foram diminuídas em cerca de $23 \%$ de $\mathrm{CO}_{2}, 18 \%$ de $\mathrm{NO}_{2}$ e $\mathrm{SO}_{2}$, e $19 \%$ de COVs, segundo apontam Marchand et al. (2008).

Todavia, embora a literatura geralmente aponte para uma redução significativa da exposição dos trabalhadores aos fumos de asfalto em obras com misturas mornas e semimornas, pode ser difícil fazer comparações diretas de resultados obtidos nos testes de medida de concentração de poluentes, pois a amostragem e os protocolos analíticos diferem de país para país (PROWELL e HURLEY, 2007).

Já o segundo benefício que as misturas mornas e semimornas podem proporcionar aos trabalhadores da pavimentação é a possibilidade de estes terem um ambiente de trabalho com temperatura mais amena e com redução de odores (NEWCOMB, 2006; BARTHEL et al., 2004; PROWELL e HURLEY, 2007).

Segundo Newcomb (2006), boas condições de ambiente de trabalho na produção e na aplicação de misturas asfálticas são importantes para a indústria,

\footnotetext{
2 Segundo Baird (1999), geralmente os hidrocarbonetos que têm propriedades benzênicas são chamados de aromáticos, e ao possuírem dois ou mais anéis de benzeno fundidos passam então a ser chamados de hidrocarbonetos policíclicos aromáticos (HPAs).
} 
uma vez que favorecem não só os empregados, mas também a qualidade do trabalho. Neste sentido, acredita-se que a melhoria do ambiente de trabalho tenha sido a responsável pelo aumento da produtividade em uma obra com mistura morna executada na Alemanha, segundo relatado pelo empreiteiro (PROWELL e HURLEY, 2007).

Em termos de odores, Barthel et al. (2004) mencionam que foram encontradas reduções expressivas em avaliações realizadas em campo em obras com misturas mornas (tipo Aspha-Min ${ }^{\circledR}$ ). Em todos os casos, o número de Unidades de Odor foi significativamente reduzido e os próprios trabalhadores confirmaram que houve melhoria significativa das condições de trabalho nestas ocasiões.

\section{Diminuição do consumo energético}

Além da questão ambiental, o setor rodoviário também tem sido obrigado a buscar tecnologias inovadoras que possam melhorar a eficiência energética nas operações de pavimentação devido à instabilidade dos preços do petróleo, embora isto também deva ser uma das metas para se alcançar uma melhor otimização dos recursos naturais (OLARD, 2008; HASSAN, 2009). Dentro deste contexto, um aspecto interessante associado às misturas mornas e semimornas é a diminuição do consumo de energia, em relação às misturas a quente convencionais; como a temperatura requerida na usinagem é mais baixa, há uma redução da quantidade de combustível necessário no processo de mistura (NEWCOMB, 2006; PROWELL e HURLEY, 2007).

De acordo com Olard (2008), a economia de energia na produção de misturas asfálticas semimornas, por exemplo, pode ser da ordem $35 \%$ a $60 \%$, dependendo do processo, do tipo de usina e dos materiais empregados.

\section{Menor envelhecimento do ligante asfáltico}

Outro aspecto interessante que se acredita estar associado à diminuição das temperaturas em misturas mornas e semimornas é a redução do envelhecimento do ligante asfáltico por oxidação (RÜHL, 2008). 
Sabe-se que as altas temperaturas têm efeito negativo sobre o asfalto e são capazes de causar alterações reológicas substanciais no ligante, levando a um aumento de sua rigidez (BROWN et al., 2009). Por consequência, durante a vida de serviço do pavimento, a mistura asfáltica com este ligante pode apresentar problemas precoces (MALLICK et al., 2009) devido a trincamentos.

Considerando-se todo o processo de pavimentação, sabe-se que este envelhecimento do asfalto ocorre principalmente durante a usinagem, devido aos maiores níveis de temperatura. Quando o ligante é mantido em temperaturas acima de $150^{\circ} \mathrm{C}$, mesmo que por tempos relativamente curtos (menores que um minuto, como ocorre na usinagem), pode sofrer envelhecimento significativo com a exposição ao ar e a perda de voláteis (RÜHL, 2008; BERNUCCI et al., 2008; BROWN et al., 2009).

Deste modo, a redução de temperatura nas misturas mornas e semimornas poderia levar a um menor enrijecimento do ligante, tornando-o mais flexível e resistente a trincas por fadiga em vida de serviço (NEWCOMB, 2006, PROWELL e HURLEY, 2007) e elevando a durabilidade do pavimento em longo prazo (PROWELL e HURLEY, 2007).

Como as misturas mornas e semimornas compõem um tipo de tecnologia de pavimentação ainda recente, as pesquisas relativas ao aumento da resistência à fadiga que ocorreria por diminuição do envelhecimento ainda estão em curso. Ferreira (2009), por exemplo, estudou em laboratório dois tipos de misturas mornas, uma com o aditivo Sasobit ${ }^{\circledR}$ e a outra com Cecabase $\mathrm{RT}^{\circledR}$, em comparação com misturas convencionais, tendo observado que a vida de fadiga de ambas, em laboratório, se mostrou igual à da mistura a quente de referência, ou seja, não constatou melhora.

Já Silva et al. (2010) avaliaram três tipos de misturas mornas com a inserção de aditivos orgânicos em comparação com misturas convencionais, porém utilizando ligantes com diferentes penetrações, e verificaram que o comportamento à fadiga foi similar quando o asfalto utilizado tinha penetração 50-70, 30-45 e 10-20. Entretanto, estes autores observaram ainda que quando se comparou uma mistura a quente com CAP $^{3} 50-70\left(150^{\circ} \mathrm{C}\right)$ com uma mistura morna com CAP 160/220 com 6\% de aditivo $\left(120^{\circ} \mathrm{C}\right)$, o resultado à fadiga foi melhor na mistura morna, acreditando-se

\footnotetext{
${ }^{3}$ CAP $=$ Cimento Asfáltico de Petróleo
} 
que a melhoria de comportamento à fadiga se deu devido ao uso do ligante mais mole associado ao menor envelhecimento que este sofreu na usinagem.

Do mesmo modo, Xiao et al. (2009) analisaram o comportamento à fadiga, por tensão controlada, de misturas mornas (com asfalto-borracha e aditivos Aspha$\mathrm{Min}^{\circledR}$ e Sasobit ${ }^{\circledR}$ ), utilizando ainda dois tipos de agregados (granito e xisto), em comparação com misturas convencionais (com ligante PG 64-22 e também modificado com $10 \%$ de borracha). As misturas passaram por envelhecimento em curto-prazo (estufa por duas horas) e, como os ensaios de fadiga foram realizados em vigotas, estas passaram por condicionamento para simulação de envelhecimento em longo-prazo. Os resultados mostraram que o envelhecimento dos asfaltos estudados não diminuiu a vida de fadiga das misturas da pesquisa, mas a adição de borracha efetivamente melhorou este comportamento. De qualquer modo, com os agregados de granito, a maior resistência à fadiga foi verificada na mistura morna com asfalto-borracha e Sasobit ${ }^{\circledR}\left(\sim 3,6 \times 10^{5}\right.$ ciclos $)$, seguida da mistura a quente com asfalto-borracha $\left(\sim 3,2 \times 10^{5}\right.$ ciclos $)$, da mistura com asfalto convencional $\left(\sim 1,3 \times 10^{5}\right.$ ciclos $)$ e por último da mistura morna com asfalto-borracha e Aspha-Min ${ }^{\circledR}$ $\left(\sim 1,3 \times 10^{5}\right.$ ciclos). Já com o agregado de xisto, o melhor comportamento à fadiga também foi observado na mistura morna com asfalto-borracha e Sasobit ${ }^{\circledR}$ $\left(\sim 0,7 \times 10^{5}\right.$ ciclos $)$, seguido da mistura a quente com asfalto-borracha $\left(\sim 0,6 \times 10^{5}\right.$ ciclos $)$, da mistura morna com asfalto-borracha e Aspha-Min ${ }^{\circledR}$ $\left(\sim 0,3 \times 10^{5}\right.$ ciclos $)$ e por último da mistura com asfalto convencional $\left(\sim 0,25 \times 10^{5}\right.$ ciclos $)$.

Todavia, embora existam pesquisadores que acreditem que a redução de temperatura possa vir a ser benéfica para diminuir o envelhecimento e evitar trincamentos devido ao menor enrijecimento, neste caso poder-se-ia criar um potencial para a perda de estabilidade da mistura asfáltica, aumentando o risco de deformação permanente. Entretanto, esta situação poderia ser contornada com o uso de agregados mais cúbicos (para aumentar o atrito interno da mistura e, por conseguinte, sua resistência ao cisalhamento) ou pela utilização de um ligante asfáltico de maior consistência (NEWCOMB, 2006).

Xiao et al. (2010) avaliaram o comportamento à deformação permanente de misturas mornas com aditivos Aspha-Min ${ }^{\circledR}$, Sasobit $^{\circledR}$ e Evotherm ${ }^{\mathrm{TM}}$, utilizando ainda três tipos de agregado (dois do tipo granito e um xisto), dois teores de umidade nos agregados ( 0 e $0,5 \%)$, dois teores de cal ( 1 e $2 \%)$, em comparação com misturas 
convencionais. Os resultados mostraram que a origem do agregado afeta significantemente a resistência à deformação permanente, independentemente do aditivo de mistura morna, do uso de cal e do teor de umidade. No mais, de modo geral, os afundamentos verificados nas misturas com alguma umidade se mostraram baixos e satisfizeram o quesito de deformação permanente. Além disso, a mistura morna com Sasobit ${ }^{\circledR}$ foi a que exibiu o melhor comportamento e as misturas com Aspha-Min ${ }^{\circledR}$ e Evotherm ${ }^{\mathrm{TM}}$ apresentaram resistências à deformação permanente similares à da mistura de referência.

\section{Uso de maiores quantidades de material fresado}

O uso de pavimentos asfálticos reciclados tem se elevado nos últimos anos, principalmente visando dar uma destinação aos resíduos provenientes da fresagem de pavimentos asfálticos e minimizando os impactos causados aos recursos naturais para a obtenção de agregados virgens (ASPHALT INSTITUTE, 2007).

Nos Estados Unidos, por exemplo, o desenvolvimento de novos métodos de reciclagem, a melhoria dos equipamentos de fresagem e novas tecnologias de incorporação dos fresados na mistura asfáltica tornaram a reciclagem um procedimento padrão, o que fez com que o pavimento asfáltico fosse hoje o produto mais reciclado no país (PROWELL e HURLEY, 2007). Além disso, os aumentos significativos dos preços do asfalto que ocorreram em 2006 e 2008, somados à diminuição das fontes de agregados com qualidade aceitável, também têm sido grandes incentivadores de tal prática (COPELAND et al., 2010).

Embora mais de $60 \%$ dos departamentos de transporte norte-americanos permitam grandes quantidades de fresados nas misturas asfálticas recicladas a quente (acima de $25 \%$ em peso de agregados), a maioria dos projetos não usa rotineiramente tais percentuais elevados, principalmente se a aplicação se destinar a camadas de rolamento e camadas intermediárias (COPELAND et al., 2010), porque podem resultar em uma mistura de baixa qualidade (BROWN et al., 2009). Além disso, se o teor de fresados for elevado, pode-se ainda ter algumas dificuldades em função do tipo de usina; no caso da drum-mixer, se a quantidade de fresados for muito grande, os agregados virgens não são suficientes para protegê-los de uma forte incidência da chama, causando uma poluição excessiva e danos ao ligante 
asfáltico destes fresados; já no caso da usina de batelada, quanto maior a quantidade de fresados, maior a temperatura necessária para aquecer os agregados virgens antes da usinagem (uma vez que os fresados não são aquecidos), para que haja uma boa homogeneização da temperatura na mistura (BROWN et al., 2009).

Além disso, como a temperatura tem efeito nas características reológicas do ligante, causando envelhecimento deste, o ideal é que o material fresado não seja submetido a temperaturas muito altas (em relação às das misturas convencionais com agregados virgens) na usinagem de misturas recicladas a quente, a fim de se prevenir um envelhecimento ainda maior do asfalto contido no fresado e a rápida deterioração da mistura. Assim, quando há grande incorporação de fresados, recomenda-se que a temperatura de usinagem se situe entre 110 e $135^{\circ} \mathrm{C}$ (MALLICK et al., 2008).

Dentro deste contexto, o emprego de misturas mornas e semimornas pode favorecer a adição de maiores quantidades de fresados na produção de misturas recicladas a quente (OLARD, 2008; BARTHEL et al., 2004; PROWELL e HURLEY, 2007). A propósito, o menor envelhecimento do novo ligante incorporado à mistura, na produção de misturas mornas e semimornas, pode ajudar no rejuvenescimento do asfalto contido nos fresados, aumentando a vida de serviço do pavimento quanto a trincamentos (PROWELL e HURLEY, 2007).

Doyle e Howard (2010) mencionam que as misturas mornas por si só já são algo relativamente novo, mas combinadas ao uso de grandes quantidades de material fresado na produção de misturas asfálticas recicladas constituem a vanguarda da pesquisa e desenvolvimento de materiais para pavimentação. Estes autores estudaram misturas mornas com $100 \%$ de material fresado e concluíram que o uso de grandes quantidades de reciclados neste tipo de mistura é viável, embora ainda sejam necessários muitos avanços, antes de sua ampla difusão, no sentido de se ter uma metodologia de projeto de mistura com estes materiais.

Menor dificuldade de aplicação em épocas ou locais de clima muito frio

O emprego de misturas mornas e semimornas pode ser favorável quando são executadas obras de pavimentação em épocas ou locais de clima muito frio (NEWCOMB, 2006; PROWELL e HURLEY, 2007), por estas serem situações em 
que há grande preocupação com perdas significativas de temperatura, que acarretam em dificuldades na compactação.

As especificações do DNIT, DER-SP, dentre outros órgãos, relativas a concretos asfálticos convencionais, com asfaltos modificados, ou ainda de outras misturas asfálticas a quente, determinam que tais misturas só podem ser fabricadas, transportadas e aplicadas quando a temperatura ambiente for superior a $10^{\circ} \mathrm{C}$.

Algumas experiências de pavimentação com diferentes tecnologias de misturas mornas, sob temperatura ambiente entre -3 a $4^{\circ} \mathrm{C}$ na Alemanha, mostraram melhor densidade do que a mistura a quente de referência, com o mesmo número ou menos passagens do rolo compactador (D'ANGELO et al., 2008).

\section{Maior habilidade para ser transportada por grandes distâncias}

Uma outra situação que pode trazer preocupação por perda significativa de temperatura da mistura asfáltica é aquela em que há a necessidade de se percorrer longas distâncias entre a usina e a pista. Dentro deste contexto, as aplicações de misturas mornas e semimornas podem ser mais favoráveis que as de misturas a quente, uma vez que a taxa de esfriamento é dada pela diferença de temperatura entre a mistura asfáltica e o meio ambiente, de forma que a mistura produzida em temperatura mais baixa esfria sob uma taxa menor, possuindo menor gradiente térmico (NEWCOMB, 2006; PROWELL e HURLEY, 2007).

Assim, como as misturas mornas e semimornas apresentam um maior potencial de tempo de estocagem e transporte, em comparação com as misturas convencionais, na ocorrência de chuva acidental ou ainda por outra razão qualquer, por exemplo, os caminhões carregados podem permanecer em modo de espera por algumas horas antes de carregar a acabadora, evitando gastos com ocasionais descartes (OLARD, 2008).

Um exemplo de aplicação de uma mistura morna com longo tempo de espera entre a fabricação e o lançamento em pista foi relatado em Prowell et al. (2007). Nesta experiência (com a tecnologia Evotherm $^{\mathrm{TM}}$ ) a mistura morna permaneceu estocada por 17 horas após a usinagem e ainda pôde ser aplicada e compactada adequadamente a $96^{\circ} \mathrm{C}$ (embora a temperatura recomendada neste caso fosse $\left.107^{\circ} \mathrm{C}\right)$. 


\section{Cuidados em usina}

Apesar de tais benefícios, ainda existem algumas eventuais preocupações que podem estar associadas às misturas mornas e semimornas, como aquela relacionada à umidade que possa ficar remanescente na mistura asfáltica (PROWELL e HURLEY, 2007; HASSAN, 2009), seja pela secagem parcial dos agregados, ou seja pela introdução de água como requerem algumas tecnologias, podendo vir a causar um problema de descolamento da película asfáltica (efeito stripping). Dentro deste contexto, muitas vezes os estudos de misturas mornas e semimornas procuram determinar, além das propriedades mecânicas, o dano por umidade induzida destes materiais (NEWCOMB, 2006).

No caso das técnicas que exigem a inserção de água, geralmente o montante necessário não é significativo: na técnica WMA Terex ${ }^{\circledR}$, por exemplo, a quantidade de água requerida é de $2 \%$ em massa de ligante, o que corresponderia a cerca de $0,1 \%$ de água incorporada a uma mistura asfáltica com $5 \%$ de asfalto. Por outro lado, no caso da água remanescente devido à secagem parcial dos agregados, é importante que estes estejam com o menor teor de umidade possível antes da usinagem, o que pode ser obtido pela cobertura dos silos, por exemplo, o que já é uma prática usualmente recomendada na estocagem de agregados em usina. Deste modo, reduzir o teor de umidade dos agregados antes da usinagem significa aumentar a chance de estes estarem secos quando forem recobertos pelo ligante (PROWELL e HURLEY, 2007).

Ademais, um outro aspecto que requer atenção na produção de misturas mornas e semimornas, no caso particular de usinas movidas a combustíveis como óleo, é o ajuste adequado do queimador. Como se deve proceder à diminuição da temperatura de usinagem, a queima pode ocorrer de maneira ineficiente se 0 queimador não estiver bem regulado, contaminando a mistura asfáltica pelo combustível líquido e diminuindo a viscosidade do ligante, levando a um aumento do consumo de combustível (PROWELL e HURLEY, 2007). Um exemplo deste tipo de problema foi observado por Ferreira (2009), quando a resistência à deformação permanente de dois tipos de mistura morna (Sasobit ${ }^{\circledR}$ e Cecabase $\mathrm{RT}^{\circledR}$ ) aplicadas em trechos experimentais caiu aproximadamente pela metade do previsto em laboratório devido à contaminação dos agregados por combustível, ocorrida durante a usinagem. 
Por fim, mais um ponto que se deve atentar em usina, particularmente durante a secagem dos agregados para a produção de misturas mornas e semimornas é a condição do filtro de mangas. Com a redução da temperatura de usinagem, pode ocorrer condensação no filtro de mangas se sua temperatura não estiver suficientemente elevada, podendo levar a um problema de corrosão (geralmente, a temperatura dos gases que adentram um filtro de mangas com boa manutenção deve estar acima de cerca de $105^{\circ} \mathrm{C}$, dependendo do tipo de combustível empregado). Assim, deve-se ter em mente que a produção de misturas asfálticas em temperaturas mais baixas também requer um balanço entre secagem adequada dos agregados e manutenção da temperatura do filtro de mangas (PROWELL e HURLEY, 2007).

\section{$\underline{\text { Custos }}$}

Em termos de gastos, o custo para se produzir misturas mornas e semimornas depende muito do tipo de tecnologia escolhida, porque todas as técnicas envolvem algum custo para serem implementadas. Porém, enquanto algumas tecnologias exigem gastos iniciais mais altos, outras não requerem tais investimentos de início, mas têm-se gastos contínuos com a compra de aditivos. 0 investimento necessário para se adotar uma determinada técnica deve ser contrabalançado com a redução do consumo energético que tal método proporciona em usina (PAVIA SYSTEMS e NAPA, 2010), e com outros aspectos como a melhoria do ambiente de trabalho na pavimentação.

As misturas mornas e semimornas têm sido aplicadas nas mesmas espessuras de uma mistura convencional, demonstrando que não há economia de gastos com uma eventual redução da quantidade de materiais empregados. Entretanto, como estas misturas permitem o uso de maiores quantidades de materiais fresados (substituindo materiais virgens) é possível que haja economia de despesas por conta disto (PAVIA SYSTEMS e NAPA, 2010).

Como as misturas mornas e semimornas ainda são um tema relativamente recente, muitas pesquisas vêm sendo desenvolvidas, principalmente acerca de: (i) características fundamentais, projeto e produção destas misturas; (ii) quantificação 
dos benefícios destas tecnologias; (iii) desempenho em longo prazo; e (iv) comportamento de misturas recicladas mornas (NEWCOMB, 2006; PROWELL e HURLEY, 2007). Para tanto, a união de esforços de técnicos e a construção de trechos experimentais são fundamentais para o melhor entendimento destas tecnologias.

O National Center for Asphalt Technology (NCAT), por exemplo, está trabalhando em um projeto (NCHRP 9-47A) com a finalidade de observar 0 desempenho de diferentes tecnologias de misturas mornas em diversos locais nos Estados Unidos, comparando-o com o de misturas convencionais. Os pesquisadores estão monitorando o desempenho das misturas mornas em curto-prazo (período de dois anos) e, a partir daí, utilizarão um método de dimensionamento mecanísticoempírico (Mechanistic-Empirical Pavement Design Guide - MEPDG) para prever o desempenho em longo-prazo. Além disso, também estão sendo feitos levantamentos da economia de energia e da redução de emissões na produção destas misturas (NCAT, 2011).

Se os resultados de longo-prazo demonstrarem que as misturas mornas e semimornas oferecem durabilidade comparável à de misturas a quente (ou ainda melhores) com custo competitivo, isto será um grande incentivo para o emprego destes materiais.

Por outro lado, é possível que a utilização de misturas mornas e semimornas também possa ser estimulada com a disseminação das técnicas (que tenderiam a baratear seu custo) e com a implementação de futuros regulamentos ambientais que requisitem redução de emissões. Sem contar que o uso destas tecnologias pode ainda ser um indicador de empresas e de empreiteiros que trabalham com projetos de pavimentos "ambientalmente amigos", principalmente se estas soluções forem adotadas em conjunto com o emprego de grandes quantidades de material fresado (PAVIA SYSTEMS e NAPA, 2010).

\section{Normas}

Atualmente ainda não existem normas que regulem estas novas técnicas, o que muitas vezes pode ser um fator inibidor para a sua utilização. Entretanto, já se têm guias de aplicação publicados, fornecimento de certificados ou mesmo a 
formação de grupos de pesquisa sobre o assunto, que devem contribuir para o desenvolvimento de normas específicas relacionadas às misturas mornas e semimornas em curto-prazo.

Na Alemanha, por exemplo, com base em experiências de campo, foi lançado em 2006 um boletim (merkblatt) sobre a aplicação de algumas técnicas de misturas mornas, onde constam informações como as temperaturas de usinagem e de compactação em função do tipo de asfalto empregado (D'ANGELO et al., 2008).

Já na França, o SETRA (Departamento de Estudos Técnicos de Vias e Rodovias), em conjunto com as agências e a indústria rodoviária, passou a emitir certificações às tecnologias de misturas mornas, após estas serem avaliadas por um certo período em laboratório e em campo, recomendando aos empreiteiros que empreguem os produtos que são certificados (D'ANGELO et al., 2008).

Nos Estados Unidos, foi instituído um grupo de pesquisas sobre misturas mornas, denominado Warm Mix Asphalt Technical Working Group (WMA TWG), com a participação de diversos segmentos envolvidos no setor rodoviário do país. Este grupo tem como objetivos: (i) desenvolver um guia nacional de investigação e implementação das tecnologias de misturas mornas no país; (ii) identificar, revisar, validar e desenvolver um manual técnico de misturas mornas, capaz de fornecer um produto de qualidade, custo e desempenho no mínimo equiparáveis às misturas convencionais, mas com o benefício da redução das emissões na produção e aplicação; e (iii) discutir os problemas que envolvem as tecnologias de misturas mornas e desenvolver soluções (FHWA, 2011). Dentro deste contexto, o NCHRP finalizou há pouco um projeto denominado "Mix Design Practices for Warm Mix Asphalt', com o objetivo de desenvolver uma metodologia de dosagem de misturas mornas, a ser publicado em meados de 2011. Este documento é uma espécie de rascunho do que deverá ser adicionado como apêndice à norma AASHTO R35 (que trata da dosagem volumétrica SUPERPAVE de misturas a quente), sob a denominação "Special Mixture Design Considerations and Methods for Warm Mix Asphalt (WMA)"4.

No Brasil existem experiências práticas e pesquisas laboratoriais com diferentes tipos de misturas mornas, embora ainda não se tenham especificações próprias para estas tecnologias. A propósito, a inexistência de normas é um grande

\footnotetext{
${ }^{4}$ Informações obtidas em <www.trb.org >. Acesso em 11 abr. 2011.
} 
impeditivo para a utilização de novas técnicas no setor brasileiro de pavimentação. Assim, o desenvolvimento de diferentes pesquisas que validem a aplicação destes métodos no Brasil é de suma importância, como forma de dar embasamento aos órgãos normativos para criar tais especificações.

\subsection{OBJETIVOS}

Esta pesquisa tem por objetivo avaliar algumas propriedades físicas e mecânicas de misturas asfálticas mornas produzidas com tecnologia que emprega aditivo surfactante, comparando-as com misturas asfálticas a quente. Dentro deste contexto, parte deste estudo foi realizado em laboratório com misturas produzidas em escala laboratorial, tendo ainda sido feita uma comparação de resultados com amostras coletadas em usinas e compactadas em laboratório. A pesquisa também foi realizada em campo, com o acompanhamento da execução de dois trechos experimentais, sendo um com uma mistura morna densa do tipo concreto asfáltico com asfalto convencional CAP 30-45, e o outro com uma mistura morna seguida de uma mistura a quente do tipo gap-graded (semidescontínua) com asfalto-borracha.

De modo complementar e simplificado, este estudo ainda tem o objetivo de avaliar e comparar as concentrações de hidrocarbonetos policíclicos aromáticos em material particulado gerado por misturas mornas e convencionais, tanto em ambiente laboratorial quanto em usina e em pista, por ocasião da execução de um dos trechos experimentais.

Esta pesquisa também busca apresentar uma estimativa simplificada da redução do consumo energético com a diminuição da temperatura de secagem/vaporização d'água/aquecimento dos agregados na produção das misturas mornas produzidas em usina, em comparação com a mistura a quente.

De modo geral, este estudo visa contribuir para um melhor entendimento destas novas tecnologias de pavimentação, particularmente de uma das técnicas existentes de mistura morna, apresentando algumas de suas características e potenciais benefícios ambientais e econômicos. 


\subsection{METODOLOGIA}

As misturas asfálticas fabricadas em laboratório foram submetidas a ensaios de resistência à tração por compressão diametral, módulo de resiliência e deformação permanente, além de testes para observar a compactação em compactador Marshall, em mesa compactadora e em prensa de cisalhamento giratório (verificação do volume de vazios), e a resistência ao dano por umidade induzida.

Do mesmo modo, as misturas produzidas em usina para os trechos experimentais também foram submetidas a tais testes, tendo ainda sido checados a granulometria e o teor de ligante após a extração e a recuperação dos materiais das misturas asfálticas. Além disso, a consistência de um dos ligantes recuperados foi verificada por meio de ensaios de penetração, ponto de amolecimento $e$ viscosidade, a fim de verificar a mudança destes parâmetros devido ao envelhecimento sofrido na usinagem.

Foi feito o acompanhamento da execução dos dois trechos experimentais, no que se refere ao modo de produção, espalhamento e compactação, além da observação das temperaturas de usinagem e compactação. No caso do primeiro trecho, antes da obra foram realizados ensaios em pista, com o levantamento de defeitos, deflexões e irregularidade longitudinal e, após a execução do trecho, novamente foram verificadas as deflexões e a irregularidade, além da textura superficial do pavimento. Também foram extraídos corpos de prova para determinação de volume de vazios e espessura, resistência à tração e módulo de resiliência. Já no segundo trecho experimental, também foram retirados corpos de prova de pista para o controle tecnológico de compactação e espessura, além de ter sido feito um levantamento da textura superficial no trecho de mistura a quente (similar à morna).

Os resultados de ensaio das misturas mornas são comparados com os das misturas a quente (referência), além de serem confrontados com limites estabelecidos em especificações relativas a cada teste. Em alguns ensaios laboratoriais realizados em equipamentos franceses (mesa compactadora e simulador de tráfego), os resultados foram por vezes confrontados com os limites indicados nas normas vigentes na França e na União Europeia, ainda que isto deva 
ser encarado como uma aproximação, já que tais especificações foram estabelecidas para condições regionais de materiais e de desempenho.

Cabe mencionar que em algumas situações, infelizmente, não foi possível realizar todos os testes com todas as misturas asfálticas estudadas, devido à indisponibilidade de material ou de equipamento de ensaio naquele momento, interferindo na mais ampla comparação de resultados em alguns casos. Além disso, o número de amostras ou corpos de prova (CPs) das misturas estudadas foi variável em cada ensaio, dependendo da quantidade de material usinado disponível para a moldagem.

Ademais, sempre que possível também foram realizadas análises de variância (ANOVA) com os resultados obtidos nos ensaios, para verificar se um grupo de misturas era considerado estatisticamente igual (EI) ou diferente (ED) de outro, a fim de auxiliar na comparação.

Já com relação às emissões asfálticas, o estudo contemplou a comparação da concentração de hidrocarbonetos policíclicos aromáticos (HPAs) no material particulado gerado por misturas a quente e morna, com amostragens feitas em ambiente de laboratório, usina e campo. A extração e a análise das amostras por cromatografia foi realizada no Instituto de Química da USP.

Por fim, esta pesquisa ainda incluiu uma estimativa simplificada da economia de energia durante o processo de secagem/vaporização d'água/aquecimento dos agregados em usina, particularmente no caso das misturas aplicadas nos trechos experimentais. Para os cálculos foram adotadas algumas hipóteses relativas às obras destes segmentos, como temperaturas e quantidade de combustível normalmente utilizada nas usinas em questão, por exemplo.

\subsection{HISTÓRICO DA TESE}

Esta Tese de Doutorado foi desenvolvida no Laboratório de Tecnologia de Pavimentação da Escola Politécnica da Universidade de São Paulo (LTP/EPUSP), sendo iniciada em 2007. Em princípio, procurou-se escolher uma tecnologia de mistura morna que não exigisse mudanças significativas nos processos usualmente empregados na produção de misturas asfálticas, uma vez que alterações muito complexas poderiam dificultar a execução e o controle de futuros trechos 
experimentais que se esperava fazerem parte desta pesquisa. Com isto, a tecnologia de uso de aditivo surfactante parecia pertinente.

Ainda neste mesmo ano, o LTP/EPUSP firmou um acordo de cooperação com duas instituições de pesquisa francesas - Ecole Spéciale de Travaux Publics (ESTP) e Laboratoire Central des Ponts et Chaussées (LCPC-Nantes) - para um estudo com misturas asfálticas mornas. Dentro desta cooperação ficou acordada a utilização do produto francês Cecabase $\mathrm{RT}^{\circledR}$ pelas três instituições.

Por outro lado, como o LTP/EPUSP vinha realizando um estudo experimental para a Concessionária NovaDutra (Grupo CCR) com diferentes tipos de misturas asfálticas convencionais, aproveitou-se a disponibilidade de materiais, bem como a caracterização destes e a dosagem já realizadas pelo Centro de Pesquisas Rodoviárias (CPR) daquela concessionária para dar início nesta Tese aos ensaios laboratoriais de uma mistura morna com Cecabase $\mathrm{RT}^{\circledR}$, sendo escolhida uma configuração de concreto asfáltico com CAP (cimento asfáltico de petróleo) 50-70.

Em 2008, o LTP/EPUSP e a Concessionária NovaDutra enviaram um projeto para obtenção de Recursos de Desenvolvimento Tecnológico (RDT) da Agência Nacional de Transportes Terrestres (ANTT) para o estudo laboratorial de uma mistura morna e sua aplicação em um trecho experimental na Rodovia Presidente Dutra. Esta pesquisa foi aprovada em 2009 e decidiu-se que a mistura morna deste estudo teria as mesmas configurações de materiais da mistura convencional que vinha sendo aplicada nos serviços de restauração na região onde possivelmente seria executado tal trecho experimental. Deste modo, os ensaios desta Tese foram direcionados para estes novos materiais, passando-se então a trabalhar com um concreto asfáltico com CAP 30-45 e agregados provenientes de outra pedreira, tendo o CPR/CCR enviado ao LTP/EPUSP a caracterização de materiais e a dosagem da mistura asfáltica convencional. Além disto, neste momento também houve mudança da origem do aditivo surfactante, uma vez que o Cecabase $\mathrm{RT}^{\circledR}$ não estava facilmente disponível no mercado brasileiro e a sua importação tinha sido bastante difícil e dispendiosa para o LTP/EPUSP. Assim, passou-se a utilizar um aditivo que também possuía características surfactantes, denominado Gemul XT14, fornecido pela empresa brasileira Quimigel.

Em novembro de 2009, o primeiro trecho experimental de mistura morna relatado nesta Tese foi executado pela concessionária NovaDutra e, embora tenha ocorrido um problema com um equipamento na pista algum tempo após o início dos 
trabalhos, verificou-se que os processos de usinagem, aplicação e compactação se deram de maneira satisfatória. Além disso, foram realizados monitoramentos periódicos neste segmento para o acompanhamento do comportamento deste segmento, sujeito a tráfego tão intenso e pesado como o da Rodovia Presidente Dutra, em Guarulhos, na Grande São Paulo.

Ainda no final de 2009, a partir de uma parceria com a Profa. Dra. Pérola Vasconcellos, do Instituto de Química da USP, esta Tese passou também a dar enfoque ao estudo de emissões de poluentes em misturas asfálticas mornas e a quente.

Já em 2010 houve a oportunidade de se ter mais um trecho experimental para esta Tese, desta vez pela Concessionária AutoBAn (também do grupo CCR). Como a referida concessionária tinha a intenção de testar uma mistura asfáltica semidescontínua tipo gap-graded com asfalto-borracha (nova camada de rolamento) ao longo de seis quilômetros na Rodovia dos Bandeirantes, montou-se um projeto em que seriam executados dois segmentos experimentais em sequência, sendo gap-graded com asfalto-borracha em temperatura convencional a quente $(5.500 \mathrm{~m})$, e gap-graded com asfalto-borracha em temperatura morna $(500 \mathrm{~m})$. Tais projetos foram fornecidos para o LTP/EPUSP, de modo que ensaios laboratoriais pudessem ser realizados em paralelo com a construção dos trechos. As obras ocorreram entre julho e setembro de 2010, com aplicação das misturas asfálticas nas três faixas de rolamento ao longo dos seis quilômetros. A pavimentação com as misturas tipo gapgraded mostrou-se satisfatória e a Rodovia dos Bandeirantes seria mais um teste importante para a mistura morna, uma vez que esta via também é sujeita a tráfego intenso e pesado.

A propósito, nesta época aproveitou-se da oportunidade de se ter um novo segmento-teste para prosseguir com a captura de emissões, desta vez realizada em ambiente de usina e de pista. Cabe mencionar que tais estudos ainda encontram-se andamento.

Neste ano de 2011 esta Tese chega ao fim, esperando-se que os diversos ensaios de laboratório e os trechos experimentais tenham, de alguma forma, contribuído para o melhor entendimento de uma destas novas técnicas de pavimentação que agora vêm sendo aplicadas no Brasil. 


\subsection{ORGANIZAÇÃO DA TESE}

Esta Tese de Doutorado está organizada em sete capítulos. O primeiro traz a INTRODUÇÃO ao assunto, descrevendo os benefícios e eventuais preocupações associados às novas técnicas de se pavimentar com misturas asfálticas em temperaturas mais baixas que o usual, além de contemplar os objetivos, a metodologia, o histórico e a organização do trabalho.

O capítulo dois, sob a denominação MISTURAS ASFÁLTICAS MORNAS E SEMIMORNAS, trata da revisão bibliográfica sobre o tema, discorrendo-se sobre a classificação das misturas asfálticas em função da temperatura, as técnicas para se produzir misturas em temperaturas intermediárias, a redução da emissão de poluentes e a economia de energia com misturas mornas e semimornas.

Já no terceiro capítulo, intitulado ESTUDO LABORATORIAL, passa-se à descrição dos experimentos e resultados de laboratório com as misturas estudadas.

O capítulo quatro, por sua vez designado TRECHOS EXPERIMENTAIS, discorre sobre os dois segmentos de campo acompanhados nesta Tese, bem como traz os resultados de ensaios laboratoriais realizados com os materiais de usina empregados em sua execução.

Já o quinto capítulo, denominado REDUÇÃO DA EMISSÃO DE POLUENTES E DO CONSUMO ENERGÉTICO, apresenta os experimentos e os resultados obtidos com as amostragens dos ambientes de laboratório, usina e pista para determinar a concentração de HPAs presentes no material particulado em cada situação, e ainda traz uma estimativa da economia de energia e de gastos com combustível obtidos com a redução da temperatura de secagem/vaporização d'água/aquecimento dos agregados.

Por fim, o capítulo seis apresenta as CONCLUSÕES E COMENTÁRIOS FINAIS de todo o estudo. 


\section{MISTURAS ASFÁLTICAS MORNAS E SEMIMORNAS}

\subsection{MISTURAS ASFÁLTICAS E A TEMPERATURA}

Os diferentes tipos de misturas asfálticas de usina podem ser classificados de acordo com a temperatura empregada em sua produção, podendo ser divididos basicamente em quatro grupos: misturas a quente, misturas mornas, misturas semimornas e misturas a frio.

As misturas a quente são preparadas a partir do aquecimento dos agregados pétreos e do ligante asfáltico, sendo a usinagem executada em níveis elevados de temperatura, da ordem de 150 a $180^{\circ} \mathrm{C}$ (ASPHALT INSTITUTE, 2007; BERNUCCI et al., 2008; BROWN et al., 2009). As misturas a quente são o tipo mais utilizado nos serviços de pavimentação (ASPHALT INSTITUTE, 2007; BERNUCCl et al., 2008), e podem ser fabricadas com diversos tipos de granulometria e de asfalto, para os diferentes níveis de tráfego, garantindo boa resistência e durabilidade.

Já as misturas semimornas e mornas são preparadas em temperaturas intermediárias às das misturas a quente e a frio, principalmente por meio do aquecimento parcial dos agregados, com o uso de asfalto ou emulsão, dependendo do tipo de tecnologia. A diferença entre as misturas semimornas e mornas está na sua temperatura final após a usinagem, onde abaixo de $100^{\circ} \mathrm{C}$ (temperatura de vaporização da água) a mistura é considerada semimorna e acima é dita morna (D'ANGELO, 2008; PROWELL e HURLEY, 2007).

Por fim, têm-se as misturas a frio que são fabricadas em temperatura ambiente com emulsões asfálticas sem aquecimento dos agregados pétreos (ASPHALT INSTITUTE, 2007; BERNUCCl et al., 2008; BROWN et al., 2009). Normalmente se restringem aos revestimentos de pavimentos de baixo ou médio volume de tráfego ou às camadas intermediárias (BERNUCCl et al., 2008; ASPHALT INSTITUTE, 2007), por muitas vezes se acreditar que possam não ser estruturalmente tão resistentes quanto as misturas a quente para serem utilizadas em camadas de revestimento de vias de tráfego elevado (BROWN et al., 2009; NEWCOMB, 2006). 
Conforme o nível de aquecimento no processo de usinagem há variação da energia consumida, como ilustrado na Figura 1, onde apresenta-se a classificação das misturas asfálticas em função de temperaturas típicas de usinagem, bem como a indicação do consumo de combustível em cada caso (números aproximados). É interessante notar que os processos de secagem e vaporização da água demandam grande quantidade energética para serem efetuados.

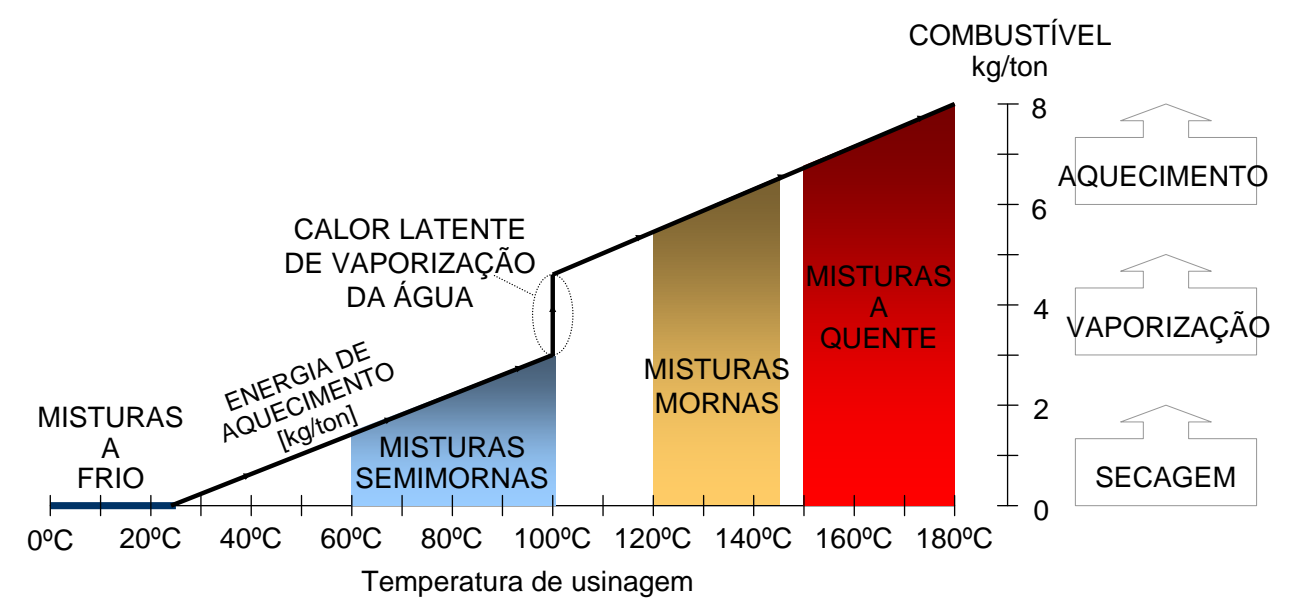

Figura 1 - Classificação das misturas asfálticas em função de temperaturas típicas de usinagem (números aproximados) adaptado de Olard (2008) e D'Angelo et al. (2008)

$\mathrm{O}$ aquecimento no processo de usinagem de misturas a quente tem três objetivos, descritos a seguir: (i) secagem dos agregados pétreos; (ii) manutenção da temperatura da mistura asfáltica; e (iii) redução da viscosidade do asfalto.

\section{Secagem dos agregados pétreos}

Uma das finalidades de se fazer uso de aquecimento na produção de misturas asfálticas é a secagem dos agregados pétreos, a fim de se evitar futuros problemas de efeito stripping. A existência de grande quantidade de água nos agregados dificulta o processo de secagem e tende a aumentar o consumo de combustível da usina (ASPHALT INSTITUTE, 2007; PROWELL e HURLEY, 2007). 


\section{Manutenção da temperatura da mistura asfáltica}

Por outro lado, a temperatura do agregado seco controla a quantidade de calor da mistura como um todo, uma vez que os agregados compõem a maior parte de uma mistura asfáltica (cerca de 95\%), sendo que a temperatura do asfalto ajustase rapidamente à dos agregados quando há a mistura de ambos. Deste modo, os agregados devem estar quentes o bastante para manter o asfalto fluido na fase de recobrimento (ASPHALT INSTITUTE, 2007). Para tanto, geralmente os agregados são aquecidos em temperatura acima do ligante, aproximadamente 10 a $15^{\circ} \mathrm{C}$ a mais, como especificado na norma DNIT ES031/06, por exemplo.

\section{Redução da viscosidade do asfalto}

O asfalto é um material que se apresenta na forma semisólida em temperatura ambiente e que passa à fase líquida em temperaturas elevadas. Deste modo, o ligante deve ser aquecido não só para ter fluidez suficiente para ser bombeado em usina, mas também para ser capaz de recobrir os agregados de maneira adequada durante a usinagem (as altas temperaturas têm grande responsabilidade na distribuição do ligante e, por consequência, na homogeneidade de uma mistura asfáltica a quente, ao diminuir a tensão superficial na interface agregado/ligante, como esquematizado na Figura 2), devendo ainda manter uma boa trabalhabilidade da massa asfáltica durante a compactação (ASPHALT INSTITUTE, 2007; HASSAN, 2009; BERNUCCI et al., 2008; BROSSEAUD, 2008).

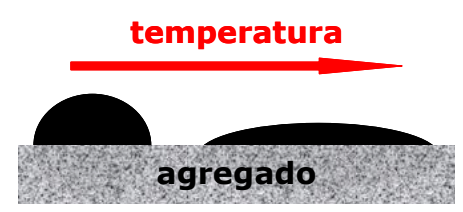

Figura 2 - Esquema de recobrimento do agregado pelo ligante asfáltico em função da elevação de temperatura adaptado de Brosseaud (2008)

As temperaturas ideais de usinagem e de compactação de uma mistura asfáltica a quente dependem do tipo de ligante empregado, sendo que os asfaltos modificados por polímeros ou borracha demandam temperaturas ainda mais altas 
devido à sua maior consistência. A especificação do DNIT de misturas asfálticas com borracha (DNIT ES112/09), por exemplo, determina que o ligante deve ser aquecido entre 170 e $180^{\circ} \mathrm{C}$ e a usinagem da mistura deve ocorrer com temperatura entre 165 e $180^{\circ} \mathrm{C}$.

A redução da temperatura na fabricação de misturas mornas e semimornas pode suscitar questionamentos principalmente quanto à secagem adequada dos agregados e ao recobrimento eficiente dos agregados pelo ligante, levando-se em conta o que foi discutido anteriormente. Isto porque a secagem dos agregados pétreos poderia não ocorrer de maneira efetiva (aumentando as chances de água remanescente na mistura e dando margem à ocorrência do efeito stripping) e o recobrimento dos agregados poderia ficar prejudicado pela menor fluidez do ligante na mistura (causando falta de homogeneidade e dificultando a compactação).

Todavia, as técnicas de misturas semimornas e mornas geralmente buscam contornar estas situações, por exemplo com o uso de agentes melhoradores de adesividade ou de produtos que reduzam a viscosidade do ligante, como será descrito a seguir.

\subsection{PRODUÇÃO DE MISTURAS ASFÁLTICAS MORNAS E SEMIMORNAS}

Atualmente, a produção de misturas asfálticas mornas e semimornas é possível a partir de: (i) espumejo do asfalto, e/ou (ii) introdução de aditivos orgânicos ou de aditivos surfactantes, diretamente no ligante ou durante o processo de mistura. Geralmente, de forma combinada a estes elementos, procede-se à diminuição da temperatura dos agregados para que a usinagem ocorra em temperatura reduzida, visto que o material pétreo compõe a maior parte de uma mistura asfáltica (cerca de 95\%) e isto já seria suficiente para baixar a temperatura de usinagem de maneira significativa. Entretanto, a diminuição da temperatura do ligante também se faz interessante, visto que isto pode contribuir para o menor envelhecimento/enrijecimento do asfalto. 
Para cada uma das formas de se produzir misturas mornas e semimornas, já foi desenvolvida uma série de técnicas e produtos nos últimos anos, sendo algumas delas detalhadas mais adiante.

\section{Espumejo do asfalto}

Um grupo de tecnologias de misturas mornas e semimornas considera a adição de uma pequena quantidade de água na mistura para a formação de uma espuma com o asfalto quente. Segundo Chowdhury e Button (2008), na verdade a técnica de se espumar o asfalto para produzir misturas asfálticas já tem algumas décadas, pois se sabe que em 1956 o professor Ladis Csanyi da lowa State University percebeu o potencial de se utilizar o asfalto espumado como um ligante de solo, e o fazia com a injeção de vapor no ligante quente. Em 1968, a Mobil Oil Australia, que tinha adquirido os direitos do método patenteado pelo professor Csanyi, modificou a técnica original, passando a injetar água fria ao invés de vapor e com isto o processo ficou mais prático. Depois disso, no início da década de 70 a Chevron desenvolveu metodologias de projeto de mistura e de pavimento para misturas asfálticas estabilizadas com asfalto emulsionado (base, mistura aberta e mistura densa), sendo posteriormente publicado um manual em 1977.

Por fim, na década de 90, começaram a surgir tecnologias de mistura morna que se valiam da técnica de espumar o ligante para que a mistura pudesse ocorrer em temperatura reduzida. Neste procedimento, o asfalto quente em contato com a água em temperatura ambiente faz com que esta se torne vapor e expanda significativamente, a um fator de 1,673 (PROWELL e HURLEY, 2007). A propósito, esta é uma razão para que a temperatura de $100^{\circ} \mathrm{C}$ seja o limiar entre uma mistura morna e uma semimorna, já que este é o ponto de vaporização da água (PAVIA SYSTEMS e NAPA, 2010).

Nas tecnologias que fazem uso deste recurso, a água é introduzida no processo de usinagem por injeção direta, por agregado úmido ou na forma de material hidrofílico como as zeólitas. Quando esta água se dispersa no asfalto aquecido e se torna vapor há a expansão do ligante, resultando em diminuição da viscosidade da mistura (PROWELL e HURLEY, 2007). 
As zeólitas são silicatos cristalinos alumino-hidratados (naturais ou sintéticos) que contêm alta porcentagem de água em sua estrutura (cerca de $20 \%$ ). Como têm a capacidade de liberar a água de maneira gradativa na medida em que são aquecidas em temperaturas acima do ponto de vaporização da água (aproximadamente entre 90 e $180^{\circ} \mathrm{C}$ ), existem tecnologias de misturas mornas que se valem desta propriedade das zeólitas para produzir o efeito de espuma (RÜHL, 2008; D'ANGELO et al., 2008).

Para viabilizar o emprego das técnicas que produzem misturas mornas e semimornas por espuma pode ser necessário realizar alterações na planta da usina, com a instalação de equipamentos para a injeção de água, câmaras de expansão ou alimentadores, por exemplo, levando assim a um certo investimento inicial. Entretanto, alguns métodos podem não requerer mudanças significativas, como quando a introdução de zeólitas é feita de modo manual, diretamente no pugmill de usinas gravimétricas (no caso da técnica Aspha-Min ${ }^{\circledR}$, por exemplo).

Dependendo do tipo de tecnologia utilizada é possível reduzir a temperatura de usinagem em até cerca $50^{\circ} \mathrm{C}$. Além disso, pode-se combinar estas tecnologias com aquelas que empregam aditivos surfactantes (descritas adiante).

Dentre alguns exemplos de técnicas de espumejo do asfalto têm-se: LEA ${ }^{\circledR}$, LT Asphalt ${ }^{\circledR}$ (misturas semimornas), Advera ${ }^{\circledR}$ WMA, AQUABlack ${ }^{\circledR}$ Warm Mix Asphalt, Aspha-Min ${ }^{\circledR}$, Double Barre ${ }^{\circledR}$ Green, LEA $B^{\circledR}$, Ultrafoam GX2 ${ }^{\mathrm{TM}}$, WAMFoam $^{\circledR}$, WMA Terex $^{\circledR}$ (misturas mornas).

\section{Aditivos orgânicos / ceras}

Um outro grupo de tecnologias de misturas mornas conta com a introdução de aditivos orgânicos/ceras para que haja redução da viscosidade do asfalto. Ao serem submetidos a temperaturas acima de seu ponto de amolecimento, estes aditivos interferem nas propriedades do ligante, fazendo com que haja diminuição da viscosidade deste último. A propósito, a escolha do tipo e da taxa de aditivo orgânico para se produzir uma mistura morna deve ser feita de modo cuidadoso, com vistas à temperatura na qual ocorre o ponto de amolecimento destes produtos e à temperatura esperada na vida de serviço do pavimento, a fim de reduzir o risco de deformação permanente e também minimizar o potencial de trincamento por baixas 
temperaturas (PROWELL e HURLEY, 2007). Isto porque por um lado pode haver redução excessiva da viscosidade do ligante utilizado, e por outro pode ocorrer um forte enrijecimento da mistura asfáltica quando há a incorporação de grandes quantidades deste tipo de aditivo.

Os aditivos orgânicos podem ser introduzidos previamente no ligante ou juntamente com este durante a usinagem, possibilitando uma redução da temperatura de mistura em cerca 30 a $40^{\circ} \mathrm{C}$. Com o resfriamento da mistura asfáltica, estes elementos se cristalizam de modo disperso no ligante, aumentando a rigidez deste asfalto e, por consequência, da mistura como um todo (RÜHL, 2008).

Dentre alguns exemplos de tecnologias de aditivos orgânicos/ceras têm-se: Asphaltan $\mathrm{B}^{\circledR}$, CCBit 113AD, Licomont BS $100^{\circledR}$ e Sasobit ${ }^{\circledR}$ (mistura morna).

\section{$\underline{\text { Aditivos surfactantes }}$}

Um outro grupo de tecnologias se vale da introdução de aditivos surfactantes no asfalto, ou em uma emulsão com elevado teor de resíduo asfáltico, para produzir as misturas mornas e semimornas. Geralmente, estes produtos agem na interface agregado/ligante e auxiliam no processo de recobrimento, podendo ainda atuar como melhoradores de adesividade (PROWELL e HURLEY, 2007; PAVIA SYSTEMS e NAPA, 2010).

Estes produtos não alteram as propriedades de consistência do asfalto, medidas em ensaios de viscosidade, penetração e ponto de amolecimento. Dentro deste contexto, Hanz et al. (2010) fizeram testes de viscosidade de ligantes com e sem um aditivo (Revix ${ }^{\mathrm{TM}}$ ) em reômetro de cisalhamento dinâmico (DSR) e verificaram que, de fato, não houve mudança nesta propriedade, mesmo em diferentes níveis de temperatura. Entretanto, quando os autores adaptaram um aparato normalmente empregado em ensaios com lubrificantes ao DSR notaram diferenças expressivas na propriedade de lubricidade dos asfaltos com e sem o aditivo para mistura morna, principalmente em temperaturas abaixo de $100^{\circ} \mathrm{C}$. Deste modo, os autores acreditam que a viscosidade não deve ser o único parâmetro avaliado no contexto de misturas mornas, devendo a lubricidade ser estudada de maneira mais aprofundada. 
A incorporação do aditivo surfactante no ligante pode ser feita previamente à usinagem (mantendo-se sob agitação) ou ainda em linha na usina. Em geral, a produção de misturas mornas com estas técnicas é relativamente simples e pode ser viabilizada muitas vezes sem a necessidade de alterações na planta da usina. Com isto, não se têm investimentos iniciais, mas deve-se considerar que haverão gastos contínuos com a compra dos aditivos.

Dependendo do tipo de tecnologia utilizada, é possível reduzir a temperatura de usinagem em cerca 30 a $40^{\circ} \mathrm{C}$, e ainda há a possibilidade de combiná-la com aquelas de espumejo de asfalto (como mencionado anteriormente).

Dentre alguns exemplos de tecnologias de aditivos surfactantes/melhoradores de adesividade têm-se: Cecabase $\mathrm{RT}^{\Theta}$, Evotherm ${ }^{\mathrm{TM}}$, Gemul XT14, QPR ${ }^{\circledR}$ QualiTherm, Rediset ${ }^{\mathrm{TM}}$ WMX, Revix ${ }^{\mathrm{TM}}$ (misturas mornas).

A seguir, tem-se o detalhamento de algumas das tecnologias de misturas mornas e semimornas citadas anteriormente.

\subsubsection{Processo espuma}

\subsubsection{LEA ${ }^{\circledast}$ (Low Energy Asphalt)}

O processo LEA ${ }^{\circledR}$ (Low Energy Asphalt), também chamado de EBE ${ }^{\circledR}$ ou $\mathrm{EBT}^{\circledR}$ (Enrobé à Basse Énergie e Enrobé à Basse Température, respectivamente), é uma tecnologia de mistura semimorna desenvolvida na França, que atualmente é comercializada pela empresa francesa Lea-Co e pela norte-americana McConnaughay Technologies.

Basicamente, a produção desta mistura semimorna se dá por espumejo do asfalto quente em contato com água contida na fração miúda dos agregados. De modo geral, o processo LEA ${ }^{\circledR}$ pode ser resumido em cinco fases (que serão ilustradas na sequência, na Figura 3), a saber:

Fase 1: Os agregados graúdos (geralmente 60 a $70 \%$ do total) passam por secagem/aquecimento em temperatura mais baixa que o usual (cerca de 120 a $150^{\circ} \mathrm{C}$, ao invés de $180^{\circ} \mathrm{C}$ ). O ligante também é aquecido, porém na temperatura 
habitual de mistura a quente (aproximadamente $170^{\circ} \mathrm{C}$, dependendo do tipo de asfalto), sendo em seguida misturado a um aditivo melhorador de adesividade e de recobrimento (em uma taxa de 0,2 a 0,5\% em massa de ligante).

Fase 2: Os materiais aquecidos são então misturados entre si, resultando em agregados recobertos por uma espessa camada de filme asfáltico.

Fase 3: Os agregados miúdos (que também podem ser provenientes de fresagem), contendo entre 3 a $4 \%$ de água e mantidos em temperatura ambiente, são finalmente misturados aos agregados graúdos com o ligante (Fase 2). Assim, o contato do asfalto quente com a umidade dos agregados finos levará ao espumejo do ligante.

Fase 4: A expansão do ligante em torno dos agregados, resulta em uma redução de temperatura da mistura a até cerca de $100^{\circ} \mathrm{C}$.

Fase 5: Ocorre o equilíbrio térmico entre o esqueleto mineral, a água residual e o ligante asfáltico, que permitirá que esta mistura semimorna possa ser aplicada em pista em temperaturas de até aproximadamente $60^{\circ} \mathrm{C}$ (OLARD, 2008; D'ANGELO et al., 2008; BROSSEAUD, 2008).

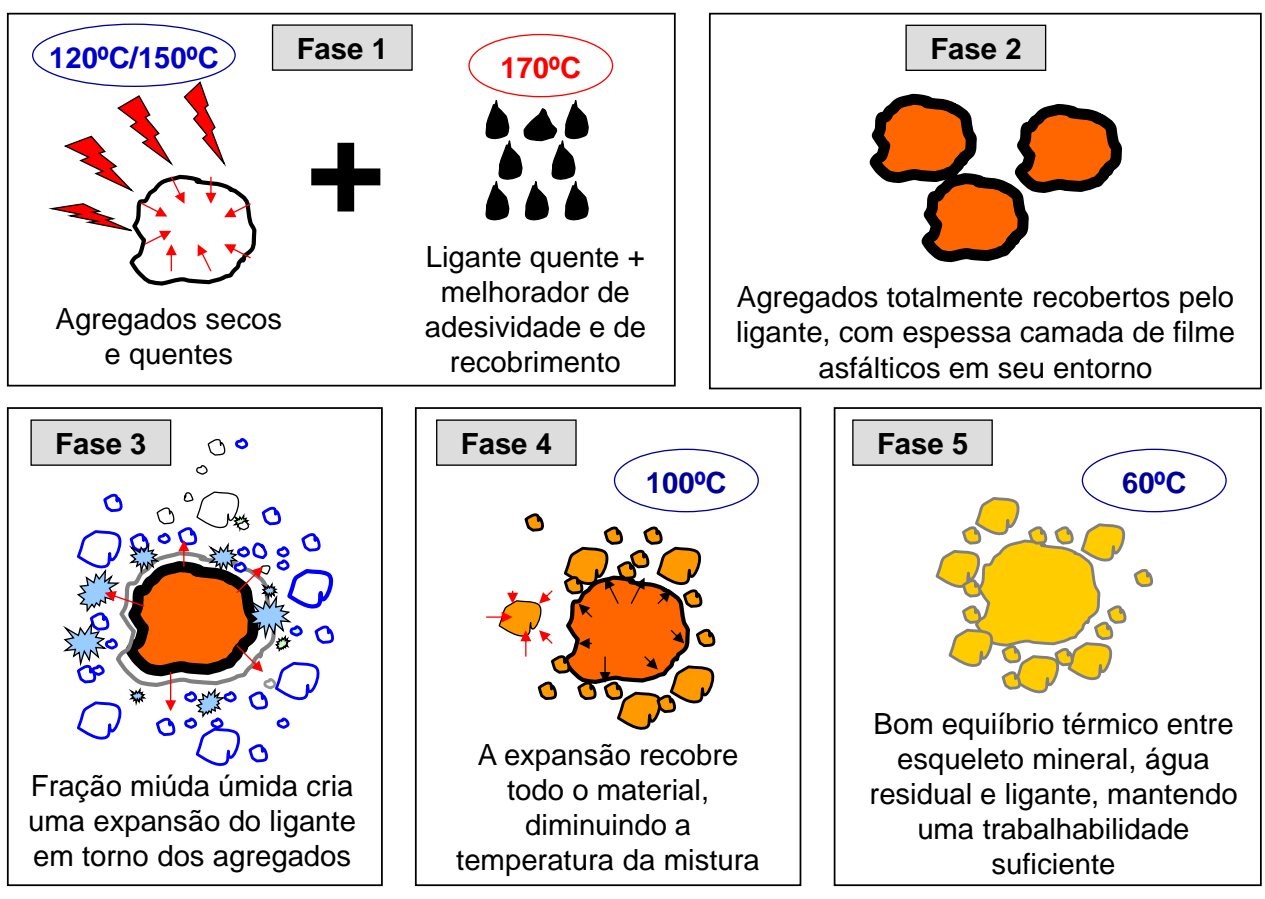

Figura 3 - Esquema de produção de mistura semimorna no processo LEA ${ }^{\circledR}$ adaptado de Brosseaud (2008), Olard (2008) e D'Angelo et al. (2008) 
$\mathrm{Na}$ etapa de projeto da mistura tipo LEA ${ }^{\circledR}$ em laboratório recomenda-se que a temperatura dos agregados graúdos seja aproximadamente $20^{\circ} \mathrm{C}$ mais baixa do que seria com a mistura em temperatura convencional (PROWELL e HURLEY, 2007).

A produção de misturas semimornas pelo processo LEA ${ }^{\circledR}$ pode ser realizada tanto em usinas gravimétricas quanto drum-mixer, desde que sejam efetuadas alterações na planta, principalmente no que se refere ao controle de umidade dos agregados (OLARD, 2008). Segundo Prowell e Hurley (2007), para viabilizar a adição do aditivo ao ligante, deve-se fazer a instalação de uma bomba volumétrica para o produto e de uma porta na linha de asfalto que vai para o misturador (usinas contínuas) ou para o pugmill (usinas de batelada).

Em usinas drum-mixer, no caso de uso de material reciclado, deve-se implementar um silo alimentador frio para a entrada dos fresados úmidos, e também é necessária a mudança de posição da linha de asfalto dentro do misturador, de forma que se garanta que os agregados graúdos sejam eficientemente recobertos pelo ligante antes da entrada do material fino úmido (PROWELL e HURLEY, 2007).

Já em usinas gravimétricas deve-se instalar um silo frio próprio para 0 material fino úmido, que deve ter sua quantidade de água monitorada. A propósito, quando houver áreas secas no montante de material miúdo, pode ser necessária a adição de água (PROWELL e HURLEY, 2007).

Olard (2008) apresenta algumas experiências de aplicação de $\operatorname{LEA}^{\circledR}$ na França. Dentre alguns aspectos observados nestas ocasiões, o autor comenta que: (i) os equipamentos empregados na compactação em pista foram os mesmos que os de uma mistura convencional a quente, entretanto a energia de compactação utilizada foi ligeiramente maior do que o usual para que fosse obtido o nível de compactação desejado (neste item cabe comentar que deveria ser feita uma avaliação para saber se o ganho obtido com a redução da temperatura de usinagem compensaria o uso de maior energia na compactação, já que haveria maior emissão de poluentes e maior consumo de combustível); (ii) a mistura LEA ${ }^{\circledR}$ parecia não grudar no caminhão basculante, reduzindo a necessidade do uso de solventes para a limpeza da caçamba; (iii) como a aplicação era feita em temperaturas abaixo de $100^{\circ} \mathrm{C}$, as propriedades exigidas para a entrega do serviço eram alcançadas mais rápido; (iv) a aparência superficial da camada acabada era similar à de uma mistura convencional. Além disso, as medidas dos níveis de macrotextura e de resistência à derrapagem se mostraram dentro dos limites exigidos. 


\subsubsection{Advera ${ }^{\circledast}$ WMA e Aspha-Min ${ }^{\circledast}$}

Advera ${ }^{\circledR}$ WMA e Aspha-Min ${ }^{\circledR}$ são zeólitas sintéticas em pó (Figura 4 e Figura 5, respectivamente) que permitem a produção de misturas mornas por meio da formação de espuma. O Advera ${ }^{\circledR}$ WMA é produzido pela empresa norte-americana $\mathrm{PQ}$ Corporation e o Aspha-Min ${ }^{\circledR}$ é fabricado pela alemã Eurovia Services $\mathrm{GmbH}$.

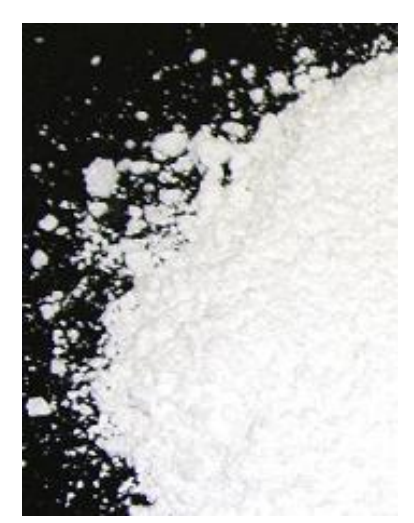

Figura 4 - Advera ${ }^{\circledR}$ WMA retirada de www.adverawma.com

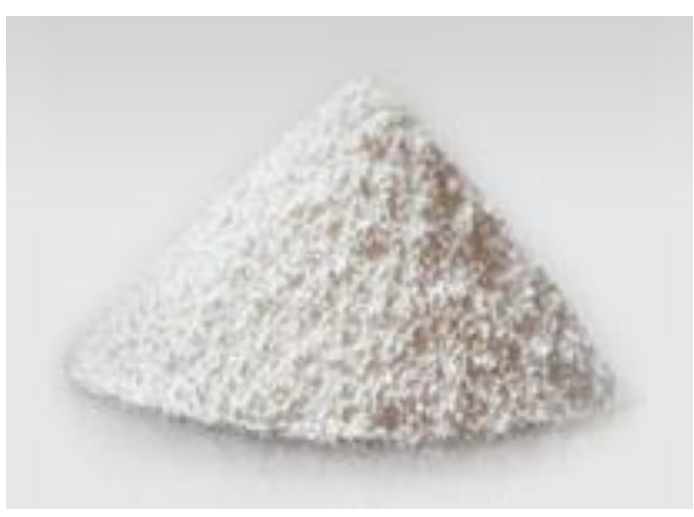

Figura 5 - Aspha-Min ${ }^{\circledR}$ retirada de www.aspha-min.com

Geralmente, estas zeólitas sintéticas são empregadas em uma taxa de 0,3\% em massa de mistura e podem ser utilizadas para produzir misturas mornas com ligantes convencionais ou modificados, bem como com diferentes tipos de granulometria (D'ANGELO et al., 2008). A temperatura final da mistura morna é cerca de $30^{\circ} \mathrm{C}$ menor do que a de uma mistura convencional (D'ANGELO et al., 2008; PROWELL e HURLEY, 2007).

Os projetos das misturas asfálticas com zeólitas sintéticas são realizados do mesmo modo que seriam com misturas convencionais, exceto pela adição destes produtos e pela redução das temperaturas de usinagem. Normalmente, nos ensaios laboratoriais, estes produtos são incorporados à mistura ao mesmo tempo em que há a entrada de ligante, embora no caso particular do Advera ${ }^{\circledR}$ WMA tem-se verificado que os resultados são melhores quando há a mistura prévia deste produto com o asfalto sob forte agitação, de forma que a dispersão destas zeólitas ocorra de maneira mais consistente (PROWELL e HURLEY, 2007).

Dependendo do tipo de usina, a incorporação do Advera ${ }^{\circledR}$ WMA e do Aspha$\mathrm{Min}^{\circledR}$ pode ser feita de diferentes formas. No caso de usinas gravimétricas, estas zeólitas podem ser adicionadas manualmente dentro do pugmill, por meio de "melt 
bags", ou automaticamente no depósito de pesagem. Já em usinas contínuas, a adição pode ser feita pela entrada de fresados, embora esta solução não seja recomendada para o Advera ${ }^{\circledR}$ WMA (que apresenta maior dificuldade de dispersão no ligante). Neste caso, é preferível inserir este produto através de um alimentador de fibras modificado, com a sua entrada no misturador próxima à do asfalto, de forma que o ligante o encapsule quando começar o efeito de liberação da água, evitando que o sistema de exaustão o carreie (PROWELL e HURLEY, 2007). Por outro lado, caso se queira melhorar a dispersão das zeólitas em usinas drum-mixer pode-se ainda instalar uma "caixa de mistura" como a apresentada na Figura 6.

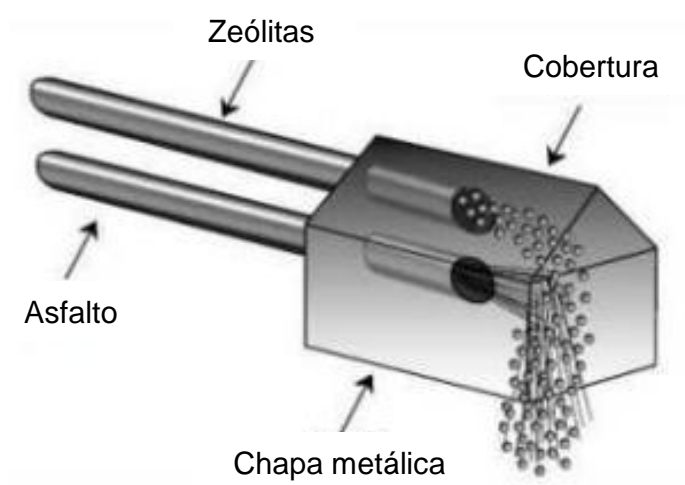

Figura 6 - "Caixa de mistura" para dispersão de zeólitas em usinas contínuas adaptado de Prowell e Hurley (2007) e Ferreira (2009)

Em pista o lançamento e a compactação das misturas mornas com estas zeólitas sintéticas são executados do mesmo modo que seriam com uma mistura convencional, onde a liberação gradual de água permite um período de seis a sete horas de boa trabalhabilidade, até que a temperatura da mistura morna caia para cerca de $100^{\circ} \mathrm{C}$ (D'ANGELO et al., 2008; PROWELL e HURLEY, 2007).

Em campo têm-se diversas experiências com Aspha-Min ${ }^{\circledR}$, tanto na Europa quanto nos Estados Unidos (D'ANGELO et al., 2008; PROWELL e HURLEY, 2007), mas uma situação particularmente interessante ocorreu em uma obra realizada na cidade norte-americana de St. Louis, no estado de Missouri, em 2006. Nesta ocasião houve uma aplicação com sucesso de uma mistura morna com Aspha-Min ${ }^{\circledR}$, ao contrário do que ocorreu com o recapeamento feito com uma mistura convencional na faixa ao lado. O pavimento asfáltico antigo possuía trincas refletidas e teve suas trincas seladas com selante à base de borracha antes de receber o novo revestimento. No caso da mistura convencional, nos pontos em que haviam as antigas trincas refletidas, observou-se a formação de "bumps" (pequenas 
elevações), o que não ocorreu na faixa de mistura morna (Figura 7). Dentro deste contexto, o empreiteiro e o Departamento de Transportes do Estado acreditam que, como a mistura a quente atendeu todas as especificações de obra e a temperatura era a única diferença entre as misturas morna e quente, a temperatura mais baixa da mistura morna foi o que preveniu o desenvolvimento dos "bumps" (HURLEY e PROWELL, 2008).

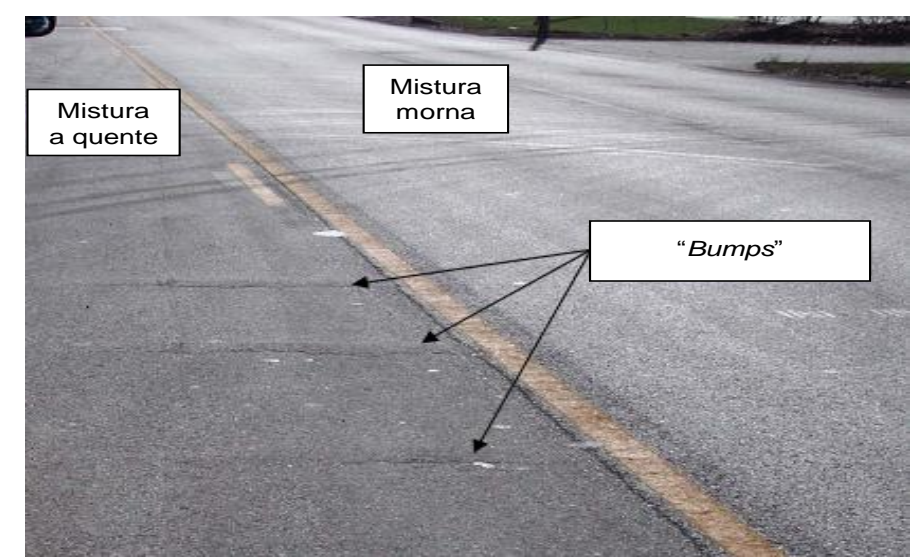

Figura 7 - Trechos experimentais de misturas a quente e morna, respectivamente com e sem a formação de "bumps" retirada e adaptada de Hurley e Prowell (2008)

Já no caso das zeólitas Advera ${ }^{\circledR}$ WMA, tem-se um exemplo de aplicação em 2007 no YellowStone National Park nos Estados Unidos, que contou também com a execução de um trecho em temperatura convencional para comparação. Nesta ocasião, um aspecto interessante verificado foi a maior uniformidade de temperatura na mistura morna, em relação à mistura a quente (Figura 8), a partir da observação de imagens térmicas que foram tiradas com a finalidade de detectar eventuais segregações térmicas (NEITZKE e WASILL, 2009). 


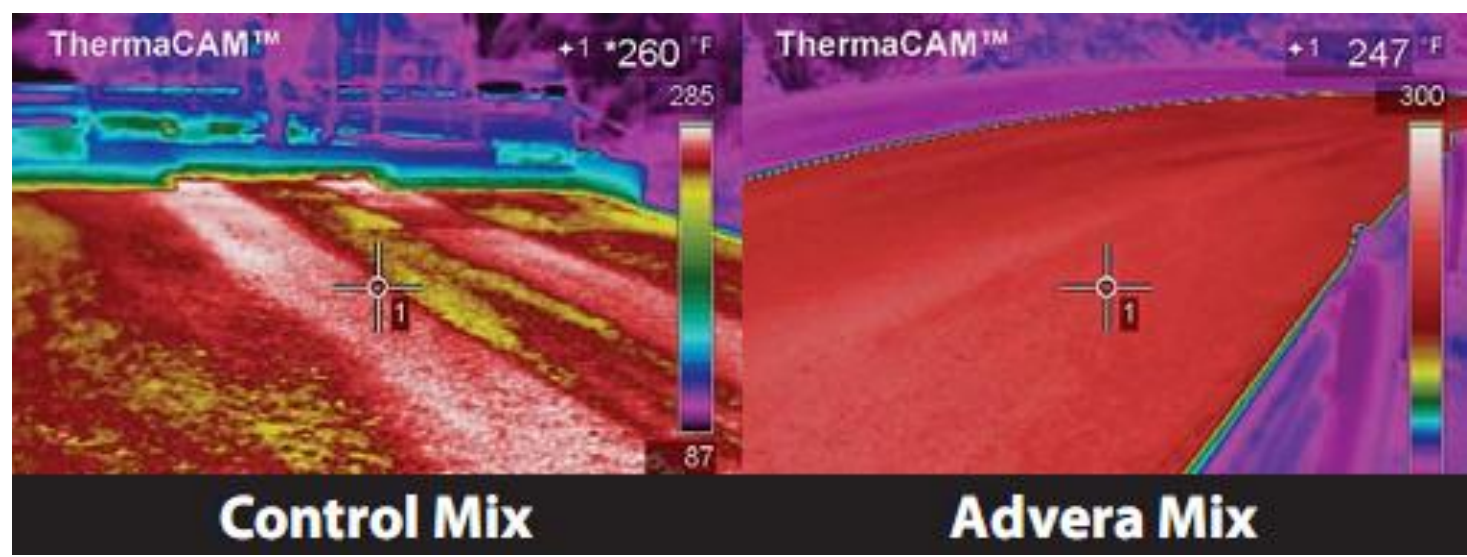

Figura 8 - Foto térmica da mistura convencional em comparação com a mistura morna Advera ${ }^{\circledR}$ WMA à esquerda e à direita, respectivamente retirado de Neitzke e Wasill (2009)

Uma parte do material utilizado nos trechos experimentais de Yellowstone Park com Advera ${ }^{\circledR}$ WMA foi enviada ao laboratório para a realização de alguns ensaios, como resistência à tração após dano por umidade induzida, teste em equipamento Hamburg Wheel Tracking e deformação permanente no equipamento APA. Os resultados indicaram que as misturas mornas não apresentaram evidências de stripping (com a adição de $1 \%$ de cal tendo sido eficiente), além de terem tido boa resistência à deformação permanente (NEITZKE e WASILL, 2009).

\subsubsection{Double Barre ${ }^{\circledR}$ Green}

A tecnologia Double Barrel ${ }^{\circledR}$ Green também aborda a produção de mistura morna por formação de espuma, mas não se trata de um aditivo e sim de um processo. É indicada para usinas drum-mixer, sendo comercializada pela empresa norte-americana Astec Industries.

Segundo Prowell e Hurley (2007), os projetos de mistura que contemplam o processo Double Barrel ${ }^{\circledR}$ Green têm sido realizados do mesmo modo que os de misturas a quente convencionais, mas para reproduzir as condições de campo é necessário que haja a instalação de um equipamento de espumejo em laboratório, recomendando-se ainda que as temperaturas de usinagem sejam da ordem de 120 a $135^{\circ} \mathrm{C}$ (PROWELL e HURLEY, 2007).

Em usina, esta técnica requer a instalação de um dispositivo acoplado ao tambor secador/misturador com um sistema de válvulas, câmaras de mistura e 
multibocais capazes de injetar uma pequena quantidade de água e, assim, espumar microscopicamente o asfalto, expandindo-o em cerca de 18 vezes (FERREIRA, 2009; PROWELL e HURLEY, 2007; MIDDLETON e FORFYLOW, 2009). A Figura 9 mostra esquematicamente como funciona um bocal de espumejo do sistema Double Barrel $^{\circledR}$ Green e a Figura 10 ilustra o dispositivo instalado no tambor da usina.

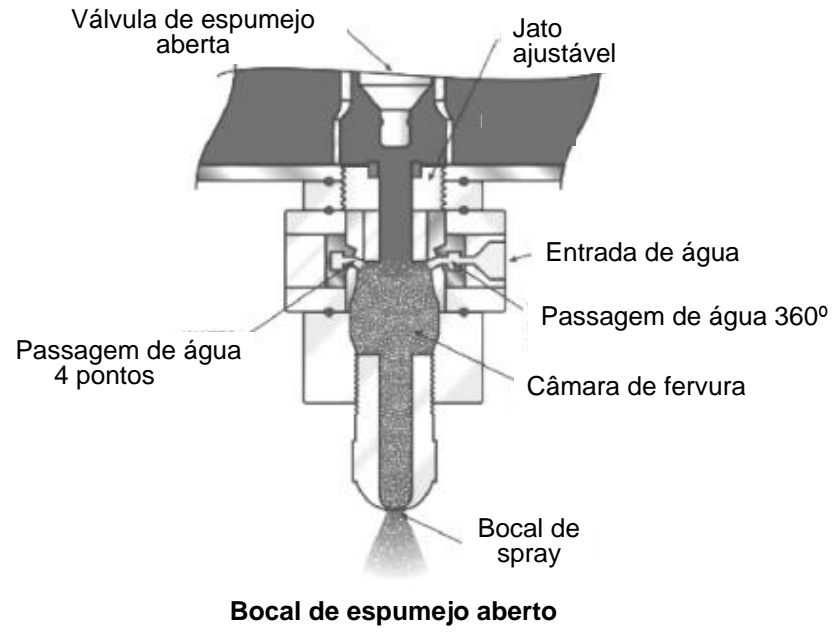

Figura 9 - Esquema de um bocal de espumejo do sistema Double Barrel ${ }^{\circledR}$ Green retirado e adaptado de www.astecin.com

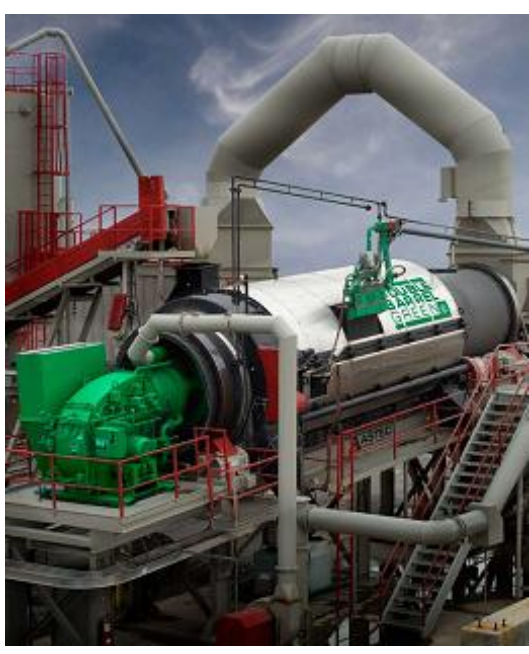

Figura 10 - Sistema Double Barrel ${ }^{\circledR}$ Green instalado em usina retirado de www.astecinc.com

Para que seja possível implementar o processo Double Barrel ${ }^{\circledR}$ Green em uma usina drum-mixer é necessário instalar o dispositivo na parte externa do tambor (sobre o sistema de injeção de asfalto existente), além de conectá-lo com linhas de alimentação de asfalto e água (MIDDLETON e FORFYLOW, 2009).

Nesta tecnologia a mistura morna normalmente é produzida com ligantes convencionais (MIDDLETON e FORFYLOW, 2009) e, para produzir uma tonelada de mistura morna, o sistema Double Barre ${ }^{\circledR}$ Green requer 0,5 kg de água (PROWELL e HURLEY, 2007; MIDDLETON e FORFYLOW, 2009). Caso se queira, pode-se ainda adicionar agentes antistripping na usinagem (D'ANGELO et al., 2008).

Normalmente, as misturas mornas no sistema Double Barrel ${ }^{\circledR}$ Green são usinadas entre 120 e $135^{\circ} \mathrm{C}$ e compactadas em até 115 a $110^{\circ} \mathrm{C}$ (MIDDLETON e FORFYLOW, 2009; D'ANGELO et al., 2008; PROWELL e HURLEY, 2007).

Nos Estados Unidos existe uma série de experiências de campo com este tipo de tecnologia, muitas delas executadas em 2007 com a incorporação de misturas asfálticas fresadas (20 a 50\%), conforme mencionam Prowell e Hurley (2007). Middleton e Forfylow (2009) apresentam um estudo canadense de misturas mornas 
com o sistema Double Barrel ${ }^{\circledR}$ Green em comparação com uma mistura em temperatura convencional. Os autores verificaram que as propriedades do ligante e da mistura asfáltica com esta técnica se mostraram similares à da mistura a quente. Além disso, observou-se que as misturas mornas apresentaram resultados satisfatórios no que se refere à suscetibilidade à deformação permanente em equipamento APA e à água em ensaio de resistência à tração.

\subsubsection{WAM-Foam ${ }^{\circledast}$}

A tecnologia WAM-Foam ${ }^{\circledR}$ está associada à produção de mistura morna por formação de espuma, tendo sido desenvolvida em conjunto pela empresa inglesa Shell Bitumen e pela norueguesa Kolo-Veidekke. Esta técnica é um processo que considera a adição de dois tipos de ligantes asfálticos, sendo um asfalto de baixa e outro de alta viscosidade (este último entra espumado no sistema), para produzir um ligante final com uma determinada consistência. Tipicamente, o asfalto mais mole possui viscosidade da ordem de 1500 centistokes a $60^{\circ} \mathrm{C}$, enquanto o ligante mais duro possui penetração 70-100 ou cerca de um PG 58/64-22 (D'ANGELO, et al., 2008; PROWELL e HURLEY, 2007).

O processo WAM-Foam ${ }^{\circledR}$ consiste em secar inicialmente os agregados pétreos graúdos em temperatura de cerca de 125 a $130^{\circ} \mathrm{C}$, e depois recobri-los com o asfalto menos viscoso (mais mole). Em seguida, o ligante de maior consistência é separadamente espumado com água, e entra na mistura junto com a parcela de fíler, fazendo com que a viscosidade desta caia e a usinagem ocorra em temperaturas de cerca de 100 a $120^{\circ} \mathrm{C}$. Por fim, a mistura com WAM-Foam ${ }^{\circledR}$ poderá ser compactada em temperaturas da ordem de 70 a $110^{\circ} \mathrm{C}$ (Figura 11). 


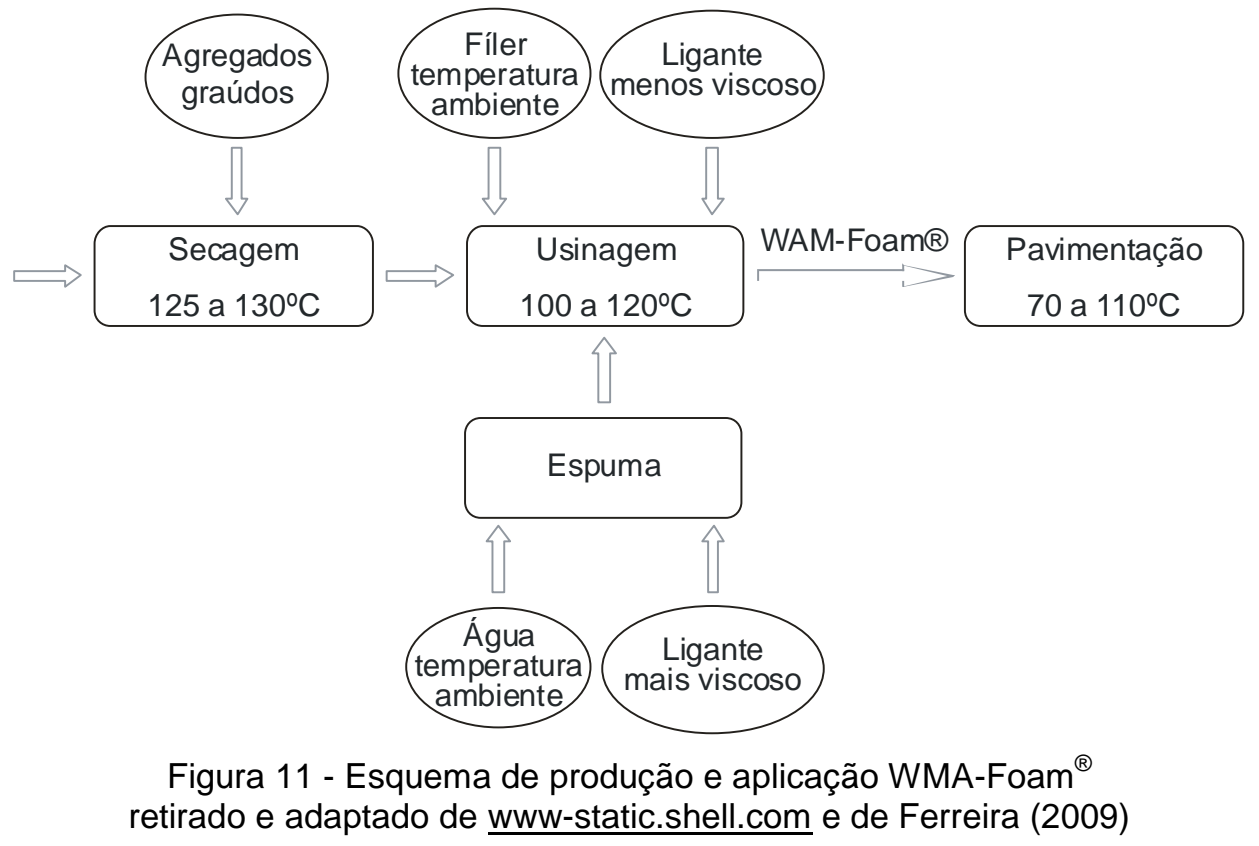

Usualmente, o ligante com viscosidade baixa representa 20 a $30 \%$ do total de asfalto da mistura na tecnologia WAM-Foam ${ }^{\circledR}$. Entretanto, pode-se alterar 0 montante deste ligante para alcançar a consistência final desejada, uma vez que a quantidade necessária para se recobrir a fração graúda é mínima, além de ser suficiente para satisfazer a absorção de asfalto. Ademais, caso se queira, pode-se ainda adicionar um agente antistripping na usinagem (misturado ao ligante menos viscoso) ou ainda algum produto que auxilie no espumejo de alguns tipos de asfalto (PROWELL e HURLEY, 2007; D'ANGELO et al., 2008).

A água adicionada para espumar o ligante mais duro corresponde a cerca de 2 a $5 \%$ da massa deste asfalto (aproximadamente $0,7 \mathrm{~kg}$ de água por tonelada de mistura, assumindo-se que esta tenha $5 \%$ de ligante, no qual $80 \%$ é constituído de asfalto mais duro). Para a formação da espuma, a água entra em temperatura ambiente e o ligante deve estar aquecido a cerca de 175 a $180^{\circ} \mathrm{C}$, o que faz com que a combinação água-asfalto expanda próximo de 15 vezes em relação a seu volume original (D'ANGELO et al., 2008; PROWELL e HURLEY, 2007).

Os projetos de mistura com a tecnologia WAM-Foam ${ }^{\circledR}$ requerem a instalação de um equipamento de espumejo em laboratório. Ademais, deve-se fazer tentativas para se determinar a temperatura "ótima" em que o asfalto de maior consistência possa ser espumado de maneira satisfatória e os agregados devem ser aquecidos à temperatura requerida pelo ligante mais mole (PROWELL e HURLEY, 2007). 
Esta tecnologia pode ser produzida tanto em usinas de batelada quanto drummixer, desde que sejam realizadas modificações na planta. No caso de usinas gravimétricas, o ligante mais mole deve ser adicionado pela entrada usual de asfalto e levado ao depósito de pesagem. A partir daí, uma segunda linha de ligante é necessária para fornecer o asfalto mais viscoso, no qual a adição é regulada por um medidor, devendo-se ainda implementar um bocal de espumejo e uma câmara de expansão acima do pugmill. É importante que a cada batelada seja introduzido um jato de ar comprimido dentro da câmara de expansão, para remover eventuais resíduos de ligante que podem ir se depositando (PROWELL e HURLEY, 2007; D'ANGELO et al., 2008).

Por outro lado, as alterações requeridas para a produção das misturas mornas WAM-Foam ${ }^{\circledR}$ em usinas contínuas são mais fáceis de serem executadas. De modo similar às usinas drum-mixer, a linha existente de asfalto é utilizada para fornecer o ligante mais mole. Além disso, há a necessidade de se proceder à instalação de outras duas linhas, uma para o asfalto mais duro e outra para a água, mas como a usina é contínua e o espumejo também, não há a necessidade de se introduzir o jato de ar comprimido para limpeza do sistema, como no caso das usinas gravimétricas (D'ANGELO et al., 2008; PROWELL e HURLEY, 2007).

Segundo Prowell e Hurley (2007) têm-se registros de experiências com WAMFoam $^{\circledR}$ em países como Noruega, França, Itália, Luxemburgo, Holanda, Suécia, Suíça, Reino Unido e Canadá. Particularmente na Noruega, tem-se uma série de trechos experimentais com esta tecnologia construídos desde o final da década de 90. D'Angelo et al. (2008) visitaram seis segmentos, com idades entre dois e oito anos, sendo que quatro trechos consistiam em misturas de graduação densa e os outros dois de SMA (stone matrix asphalt). Os autores relatam que os segmentos aparentavam estar em boas condições, embora em alguns pontos pôde-se notar a existência de deformação permanente. Entretanto, acredita-se que este tipo de patologia não seja atribuído à mistura morna com WAM-Foam ${ }^{\circledR}$ em si, mas sim ao uso de pneus com pinos (tal prática ainda é permitida no país, embora esteja diminuindo, principalmente por conta da aplicação de multas). Esta conclusão se deve ao fato de que pavimentos com misturas a quente também apresentavam as mesmas características, levando inclusive a crer que as misturas mornas demonstravam desempenho similar ao das misturas convencionais. 


\subsubsection{WMA Terex ${ }^{\circledR}$}

Seguindo a mesma linha das técnicas apresentadas anteriormente, a tecnologia WMA Tere ${ }^{\circledR}$ trata da produção de misturas mornas pela formação de espuma, tendo sido desenvolvida pela empresa norte-americana Terex.

Esta técnica é indicada para usinas contínuas de contrafluxo, requerendo a instalação de um tanque e de uma bomba de água na planta da usina, além de uma caixa de expansão acoplada a uma barra espargidora de injeção que adentra o tambor secador, como mostra o esquema da Figura 12. Neste sistema há uma válvula seletora que permite que a produção da mistura asfáltica passe para o procedimento convencional, quando assim o desejar.

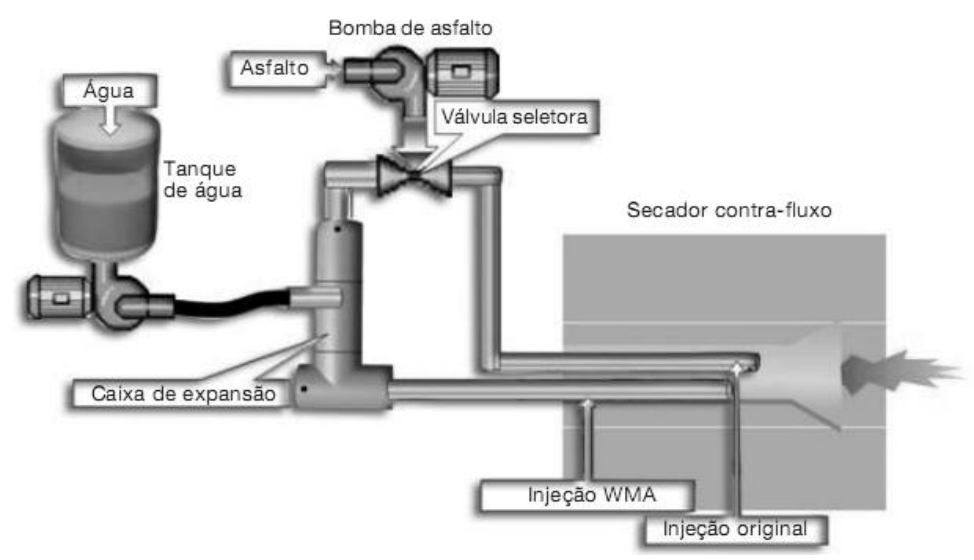

Figura 12 - Esquema de instalação de dispositivos no processo WMA Terex ${ }^{\circledR}$ retirado e adaptado de www.terexrb.com.br

A fabricação de mistura morna pela tecnologia WMA Tere ${ }^{\circledR}$ é iniciada pelo bombeamento de água e asfalto para a caixa de expansão, em proporções controladas por um painel de controle instalado junto ao tanque de água. Nesta câmara o ligante expande a uma taxa de aproximadamente 20 vezes, formando o asfalto espumado, cuja meia-vida é de cerca de 20 segundos (Figura 13). Este é então levado pela barra espargidora de injeção para o tambor de contrafluxo, para que seja misturado com os agregados em temperatura de 135 a $145^{\circ} \mathrm{C}$. Cabe mencionar que a quantidade de água usualmente empregada nesta técnica é de $2 \%$ em massa de ligante, o que corresponde a $1 \mathrm{~kg}$ de água por tonelada de uma mistura asfáltica com 5\% de asfalto (ANTONELLO e MORILHA JR, 2010). 

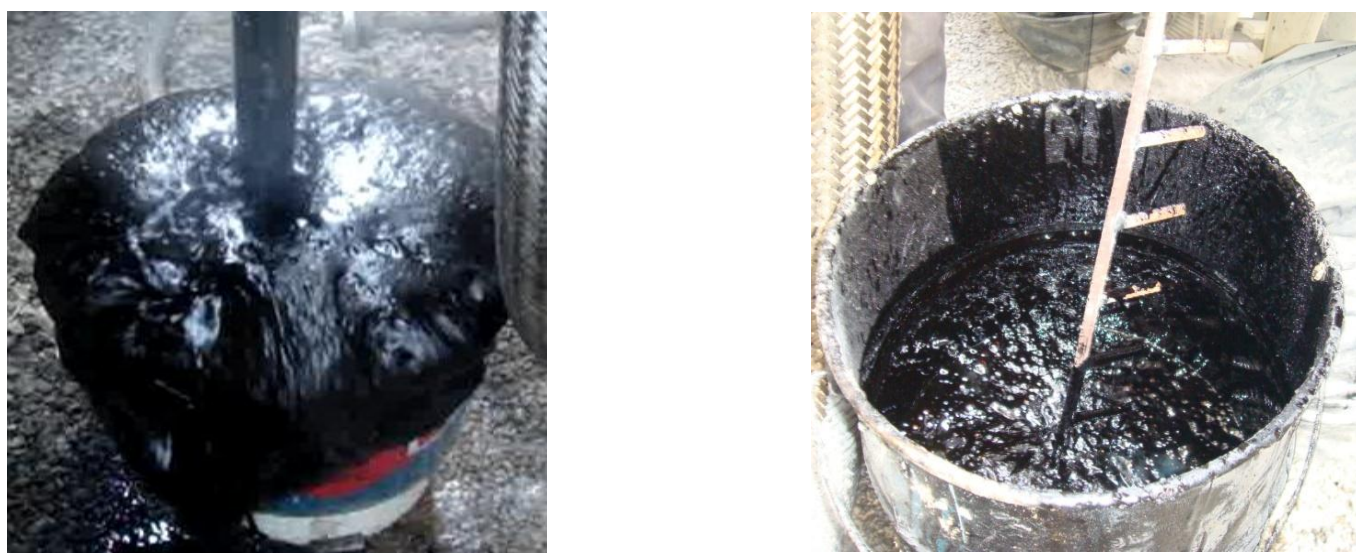

Figura 13 - Asfalto espumado e após a meia-vida no processo WMA Terex ${ }^{\circledR}$ retirado de Antonello e Morilha Jr (2010)

\subsubsection{Aditivos orgânicos / ceras}

\subsubsection{Sasobit ${ }^{\circledR}$}

O Sasobit ${ }^{\circledR}$ é uma cera parafínica, tipo Fischer-Tropsch (F-T), produzida pela empresa alemã Sasol Wax $\mathrm{GmbH}$, que permite a produção de misturas mornas por redução da viscosidade do ligante. As ceras F-T são obtidas a partir da gaseificação do carvão na presença de um catalisador e caracterizam-se por uma longa cadeia de hidrocarbonetos alifáticos de polimetileno (HURLEY e PROWELL, 2005b).

Este produto é comercializado tanto em flocos quanto em pastilhas (Figura 14), sendo os flocos recomendados para a adição no ligante e as pastilhas para a incorporação na mistura asfáltica (HURLEY e PROWELL, 2005b).
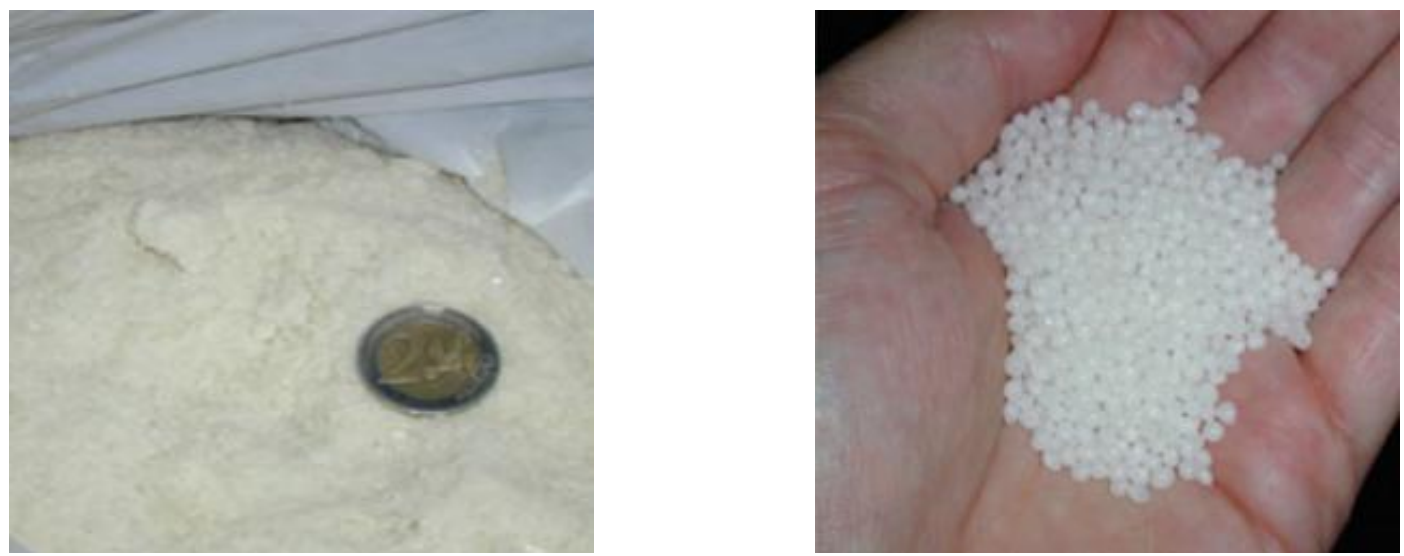

Figura 14 - Sasobit ${ }^{\circledR}$

à esquerda em flocos e à direita em pastilhas, respectivamente retirado de Hurley e Prowell (2005b) 
O Sasobit ${ }^{\circledR}$ pode ser utilizado para produzir misturas mornas com ligantes convencionais ou modificados, bem como com diferentes tipos de granulometria, sendo usualmente empregado em taxas que variam de 0,8 a $4 \%$ em massa de ligante, não sendo recomendado acima disto porque pode causar enrijecimento significativo do asfalto em baixas temperaturas (D'ANGELO et al., 2008; WASIUDDIN et al., 2007).

Este aditivo tem ponto de amolecimento de cerca de $100^{\circ} \mathrm{C}$ e pode ser adicionado ao ligante previamente à usinagem ou juntamente com este no momento da mistura. Após ser incorporado ao asfalto, o Sasobit $^{\circledR}$ se solidifica em temperaturas entre 65 e $115^{\circ} \mathrm{C}$, ficando com a aparência de microscópicas partículas alongadas regularmente distribuídas em meio ao ligante (PROWELL e HURLEY, 2007), o que inclusive leva alguns a acreditar que é essa estrutura que faz com que haja um aumento da viscosidade do asfalto nas maiores temperaturas de serviço do pavimento (D'ANGELO et al., 2008), tornando-o mais resistente à deformação permanente (WASIUDDIN et al., 2007).

Segundo Prowell e Hurley (2007), os projetos de mistura com Sasobit ${ }^{\circledR}$ têm sido realizados do mesmo modo que os de misturas convencionais, havendo somente a incorporação do produto na mistura e a redução da temperatura de usinagem. Sua adição pode ser feita tanto ao asfalto antes da usinagem, quanto à mistura imediatamente antes da entrada do ligante ou em conjunto com este (PROWELL e HURLEY, 2007).

As misturas mornas com Sasobit ${ }^{\circledR}$ incorporado no momento da usinagem podem ser preparadas tanto em usinas drum-mixer quanto em gravimétricas. No caso particular das usinas contínuas, o produto pode ser introduzido através da entrada de fresados, embora seja preferível usar um alimentador (similar ao utilizado para fibras) que controle a quantidade e o insira no tambor. Neste tipo de usina é interessante que a entrada deste aditivo seja feita no mesmo ponto em que há a adição do asfalto no misturador (PROWELL e HURLEY, 2007).

A temperatura final da mistura morna com Sasobit ${ }^{\circledR}$ é até $30^{\circ} \mathrm{C}$ menor do que a temperatura de uma mistura convencional (MALLICK et al., 2009; WASIUDDIN et al., 2007). A propósito, o merkblatt alemão especifica que as temperaturas de usinagem de misturas mornas com Sasobit ${ }^{\circledR}$ devem se situar entre 130 a $170^{\circ} \mathrm{C}$, dependendo da consistência do asfalto empregado (D'ANGELO et al., 2008). 
Em pista o lançamento e a compactação das misturas mornas com este aditivo são feitos do mesmo modo que seriam com uma mistura convencional, como foi verificado, por exemplo, em uma experiência relatada por Diefenderfer et al. (2008). Os autores discorrem sobre a execução de dois trechos experimentais de mistura morna com $1,5 \%$ de Sasobit $^{\circledR}$, acompanhados de dois segmentos convencionais comparativos, construídos no ano de 2006 no Estado norteamericano da Virgínia. No primeiro caso, em que inclusive houve a adição de 10\% de fresados, a mistura morna foi usinada a $120^{\circ} \mathrm{C}$, enquanto sua mistura de referência foi executada a $150^{\circ} \mathrm{C}$. No segundo caso, com $20 \%$ de fresados, a mistura morna foi usinada a $150^{\circ} \mathrm{C}$, ao passo que a mistura a quente foi preparada a $165^{\circ} \mathrm{C}$. Os resultados mostraram que os volumes de vazios médios das misturas mornas com Sasobit ${ }^{\circledR}$ se mostraram ligeiramente menores do que aqueles das misturas de controle, mas com diferença estatisticamente insignificante.

Dentro deste contexto, é interessante relatar um aspecto verificado no estudo de Ferreira (2009), cuja pesquisa considerava uma mistura morna com $4 \%$ de Sasobit ${ }^{\Theta}$, em comparação com uma mistura convencional. Na etapa laboratorial deste estudo avaliou-se, dentre outras coisas, a resistência ao processo de compactação com a redução de temperatura. Como já era esperado, houve maior dificuldade de densificação à medida que a temperatura diminuía, entretanto notouse que a resistência ao processo de compactação da mistura morna com Sasobit ${ }^{\circledR}$ foi ligeiramente menor do que a da mistura quente, o que faz com que a autora suspeite que o aditivo deva alterar a forma como a estrutura interna da mistura resista aos esforços de densificação.

\subsubsection{Aditivos surfactantes / melhoradores de adesividade}

\subsubsection{Cecabase $R T^{\circledR} /$ Gemul $X T 14$}

O Cecabase $R T^{\circledR}$ e o Gemul XT14 são aditivos em forma líquida, que atuam como tensoativos ou agentes de superfície (surfactantes), permitindo que o ligante possa recobrir os agregados adequadamente quando a usinagem ocorre em temperaturas mais baixas que o habitual para a produção de misturas mornas. Além disso, atuam como melhoradores de adesividade. 
O Cecabase $\mathrm{RT}^{\circledR}$ é fabricado pela empresa francesa Ceca do grupo Arkema, enquanto o Gemul XT14 é um produto da empresa brasileira Quimigel. Segundo o fornecedor do Gemul XT14, este aditivo é um agente tensoativo composto de amidas sintéticas.

A Tabela 1 indica algumas propriedades físicas destes aditivos, conforme informações dos fabricantes.

Tabela 1 - Propriedades físicas do Cecabase $\mathrm{RT}^{\circledR}$ e do Gemul XT14

\begin{tabular}{ccc}
\hline Propriedade & Cecabase $\mathrm{RT}^{\circledR}$ & Gemul XT14 \\
\hline Estado físico a $25^{\circ} \mathrm{C}$ & líquido & líquido \\
\hline Densidade específica a $25^{\circ} \mathrm{C}\left[\mathrm{g} / \mathrm{cm}^{3}\right]$ & 1,0 & 0,94 \\
\hline Solubilidade em água & Insolúvel & Insolúvel \\
\hline Inflamabilidade & não inflamável & não inflamável \\
\hline Ponto de fulgor $\left[{ }^{\circ} \mathrm{C}\right]$ & $>100$ & $>179$ \\
\hline
\end{tabular}

O Cecabase $\mathrm{RT}^{\circledR}$ e o Gemul XT14 podem ser utilizados em misturas mornas com ligantes convencionais ou modificados, bem como com diferentes tipos de distribuição granulométrica, permitindo que a temperatura da mistura asfáltica final seja cerca de $30^{\circ} \mathrm{C}$ inferior à de uma mistura em temperatura convencional.

O Cecabase $\mathrm{RT}^{\circledR}$ e o Gemul XT14 são usualmente empregados em uma taxa entre 0,2 e $0,5 \%$ da massa de ligante, podendo ser adicionados diretamente ao asfalto (mantendo-se sob agitação) ou em linha, na usina. Estes aditivos não alteram as propriedades de consistência do ligante (conforme mencionado anteriormente), como foi constatado nos estudos de González-León et al. (2009) e de Ferreira (2009). Nesta última pesquisa, por exemplo, foram avaliadas as características de viscosidade, penetração e ponto de amolecimento de misturas mornas com diferentes taxas de Cecabase $\mathrm{RT}^{\circledR}(0,2$ a $0,4 \%)$ e concluiu-se que este aditivo não teve influência nestas propriedades.

Os projetos de mistura com estes aditivos têm sido realizados do mesmo modo que os de misturas convencionais, havendo diferenças somente no que se refere à introdução destes produtos e à redução das temperaturas de usinagem.

A incorporação do Cecabase $\mathrm{RT}^{\circledR}$ e do Gemul XT14 no processo de produção de mistura morna é simples e não requer alterações na planta de usina, podendo ser feita em gravimétricas ou drum-mixer. Por outro lado, há ainda a opção da usina já 
receber o ligante misturado a este aditivo, diretamente do fornecedor de asfalto, como tem sido feito no caso do Gemul XT14.

González-León et al. (2009) realizaram ensaios laboratoriais com uma mistura morna com 0,4\% de Cecabase $\mathrm{RT}^{\circledR}$ em CAP $35-50\left(100\right.$ a $\left.120^{\circ} \mathrm{C}\right)$, em comparação com uma mistura convencional $\left(160^{\circ} \mathrm{C}\right)$, e verificaram resultados iguais de comportamento quanto ao volume de vazios em prensa de cisalhamento giratório (PCG), teste Duriez (dano por umidade) e deformação permanente em simulador de tráfego LPC, todos dentro dos limites estabelecidos nas normas francesas. Além disso, estes pesquisadores também relatam experiências de campo com misturas mornas preparadas com Cecabase $\mathrm{RT}^{\circledR}$ desde 2005 , na Espanha $\left(137^{\circ} \mathrm{C}\right)$, Polônia (com asfalto modificado por polímero SBS - estireno-butadieno-estireno - a $130^{\circ} \mathrm{C}$ ), na Itália (com $40 \%$ de fresados, a $145^{\circ} \mathrm{C}$ ) e na Dinamarca (com $50 \%$ de fresados, a $\left.130^{\circ} \mathrm{C}\right)$. Os autores citam ainda uma experiência na França com uma mistura tipo EME (enrobé à module elevé), que se caracteriza pelo uso de asfaltos muito duros e normalmente requer altas temperaturas de usinagem, da ordem de $170^{\circ} \mathrm{C}$, mas que nesse caso foi feita a $135^{\circ} \mathrm{C}$. Segundo González-León et al. (2009), todas estas experiências com o Cecabase $\mathrm{RT}^{\circledR}$ foram positivas.

Ferreira (2009) avaliou em laboratório o comportamento quanto à deformação permanente, módulo de rigidez e fadiga de misturas mornas com 0,3\% de Cecabase $\mathrm{RT}^{\circledR}$ (usinadas a cerca de 120 a $130^{\circ} \mathrm{C}$ ), em comparação com uma mistura em temperatura convencional $\left(160^{\circ} \mathrm{C}\right)$, ambas com ligante convencional de penetração 50-70. Neste caso, a autora concluiu que as misturas asfálticas se mostraram muito semelhantes em todos os quesitos.

\subsubsection{Evotherm ${ }^{T M}$}

A tecnologia de mistura morna Evotherm ${ }^{\mathrm{TM}}$ utiliza um "pacote químico" misturado a uma emulsão ou a um asfalto, tendo sido desenvolvida pela empresa norte-americana MeadWestvaco. A tecnologia Evotherm ${ }^{\mathrm{TM}}$ permite que a redução de temperatura de usinagem e de compactação de misturas mornas seja da ordem de 50 a $75^{\circ} \mathrm{C}$ em comparação com uma mistura em temperatura convencional (D'ANGELO et al., 2008). 
Este pacote químico tem a finalidade de melhorar o recobrimento (por meio de surfactantes, que atuam como agentes emulsificantes), a adesividade e a trabalhabilidade das misturas asfálticas em temperaturas reduzidas, sendo que cerca de $50 \%$ deste material é derivado de fontes renováveis. Tal pacote químico muda de acordo com o tipo de agregado utilizado, variando-se principalmente os agentes melhoradores de adesividade (D'ANGELO et al., 2008).

No processo originalmente criado, denominado Evotherm ${ }^{\mathrm{TM}}$ Emulsion Technology (ET), o pacote químico é misturado a uma emulsão com alto resíduo de asfalto $(70 \%)$ e, posteriormente, a estocagem deve ser feita a $80^{\circ} \mathrm{C}$. Na usinagem esta emulsão deve ser misturada com os agregados aquecidos, a fim de fabricar misturas asfálticas com temperaturas entre 85 e $115^{\circ} \mathrm{C}$, sendo que nesta etapa a maior parte da água contida na emulsão vira vapor quando há o contato com os agregados quentes. No fim, estes últimos ficam bem recobertos e a mistura morna resultante aparenta uma cor negra, bem característica de misturas a quente (PROWELL e HURLEY, 2007; D'ANGELO et al., 2008).

Mais tarde, o Evotherm ${ }^{\mathrm{TM}}$ ET passou a ser substituído por um novo processo denominado Evotherm ${ }^{\mathrm{TM}}$ Dispersed Asphalt Technology (DAT), no qual o mesmo pacote químico passou a ser diluído com uma pequena quantidade de água e injetado em um ligante, e não mais em uma emulsão, sendo esta injeção realizada diretamente na linha de asfalto, imediatamente antes do misturador de usinas drummixer ou diretamente no pugmill de usinas gravimétricas (D'ANGELO et al., 2008).

No caso da tecnologia ET, o pacote químico é vendido já misturado à emulsão, enquanto na DAT o cliente recebe somente tal produto para incorporá-lo ao ligante, reduzindo os custos de transporte, devido ao volume de material, e permitindo que a usina transite rapidamente entre os processos de fabricação da mistura morna e da mistura convencional (D'ANGELO et al., 2008).

Segundo Prowell e Hurley (2007), no que se refere aos projetos de mistura, estes podem variar, dependendo se a técnica utilizada é a Evotherm ${ }^{\mathrm{TM}}$ ET ou DAT. Para fabricar misturas mornas em laboratório pelo método ET, a emulsão deve estar estocada a $80^{\circ} \mathrm{C}$ antes da usinagem e os agregados devem ser aquecidos a uma temperatura aproximadamente $20^{\circ} \mathrm{C}$ acima da temperatura que se espera compactar a mistura morna em campo. Do mesmo modo, no método DAT, os agregados são aquecidos cerca de $20^{\circ} \mathrm{C}$ acima da temperatura de compactação, mas o asfalto deve 
estar na temperatura usual de misturas convencionais, entrando antes do pacote químico diluído (taxa de $5 \%$ em massa de asfalto).

Dependendo do tipo de processo, as alterações necessárias em usina são variáveis. No caso do método ET, a emulsão pode ser bombeada diretamente da carreta ou estocada em um tanque, mas deve-se atentar para a quantidade de asfalto residual na emulsão, podendo haver a necessidade de aumento do seu teor para que a quantidade de água fique em 30\%. Já na técnica DAT, requer-se a instalação de uma bomba volumétrica para o pacote químico e de um ponto de injeção na linha existente de asfalto (D’ANGELO et al., 2008).

Com relação às experiências de campo, Prowell e Hurley (2007) listam diferentes obras com Evotherm ${ }^{\mathrm{TM}}$ nos Estados Unidos, tanto pela técnica ET quanto pela DAT, entre 2005 e 2007. É possível observar que já existem aplicações destas misturas mornas com o uso de material fresado e com uma grande variedade de materiais (ligantes de diferentes consistências e tipos de agregados com diferentes tamanhos máximos nominais).

\subsubsection{Rediset ${ }^{T M}$ WMX}

O Rediset ${ }^{\mathrm{TM}}$ WMX é um aditivo produzido pela empresa holandesa Akzo Nobel, que combina agentes surfactantes e aditivos orgânicos, sendo comercializado em forma de pastilhas (Figura 15). Esta combinação contêm elementos que melhoram o recobrimento do ligante sobre a superfície dos agregados, que proporcionam efeito antistripping à mistura asfáltica por atuarem como melhoradores de adesividade e que ainda conferem alguma redução da viscosidade do ligante, permitindo que a temperatura da mistura asfáltica final seja cerca de $30^{\circ} \mathrm{C}$ inferior à de uma mistura em temperatura convencional (PROWELL e HURLEY, 2007). 


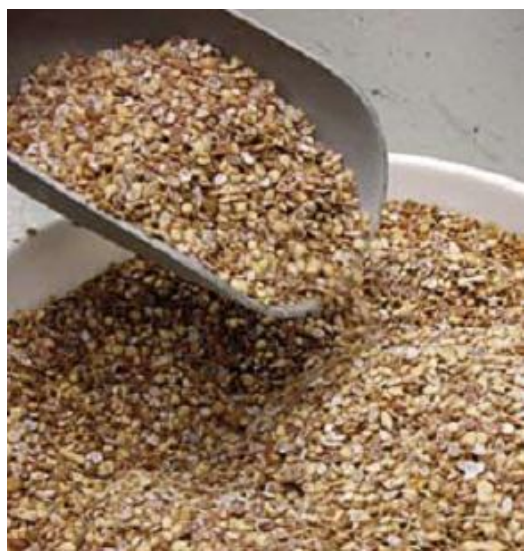

Figura 15 - Rediset $^{\mathrm{TM}}$ WMX retirado de www.akzonobel.com

Os projetos de mistura com o Rediset ${ }^{\mathrm{TM}}$ WMX têm sido realizados do mesmo modo que aqueles de misturas convencionais, havendo diferenças somente no que se refere à adição deste produto e à redução das temperaturas de usinagem.

Geralmente, este produto é empregado em uma taxa de 1,5 a 2,5\% em massa de ligante, o que não é suficiente para alterar significativamente as propriedades de consistência do asfalto em que é adicionado. Ademais, a incorporação do Rediset ${ }^{\mathrm{TM}}$ WMX na produção de misturas mornas é simples e não necessariamente requer alterações na planta de usina, podendo ser feita diretamente no tanque de asfalto aquecido ou na mistura (preferivelmente logo depois da entrada do asfalto) em usinas gravimétricas ou drum-mixer. No caso particular de usinas contínuas, a inserção do Rediset ${ }^{\mathrm{TM}}$ WMX no misturador pode ser feita por meio de um alimentador pneumático ou mesmo por um sistema como apresentado anteriormente na Figura 6. Por outro lado, há ainda a opção da usina já receber o ligante misturado a este aditivo na dose preferida diretamente do fornecedor de asfalto (PROWELL e HURLEY, 2007).

No mais, devido ao seu efeito antistripping, não há a necessidade de se adicionar outros elementos que possuam esta ação, como cal hidratada, por exemplo (PROWELL e HURLEY, 2007). Isto pôde ser comprovado por Cavalcanti et al. (2010), que avaliaram em laboratório a resistência retida à tração no ensaio de

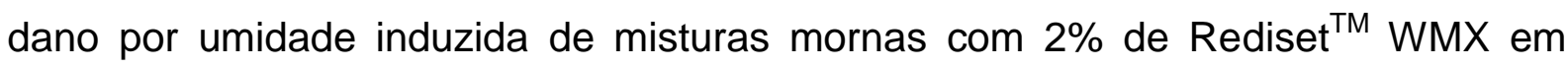
comparação com uma mistura em temperatura convencional; os autores notaram que as misturas mornas apresentaram boa resistência neste teste, enquanto a mistura de referência não atingiu a resistência mínima exigida na norma de concreto asfáltico no Brasil (70\%). 


\subsubsection{Revix $^{T M}$}

O Revix ${ }^{\mathrm{TM}}$ é uma tecnologia de misturas mornas produzidas com aditivos surfactantes, que foi desenvolvida pelas empresas norte-americanas Mathy Technology and Engineering Services e Paragon Technical Services. Segundo Prowell e Hurley (2007), este sistema se baseia no uso de uma variedade de surfactantes, ceras, auxiliares de processo, polímeros, ácidos e outros materiais, permitindo que haja uma redução do atrito interno entre as partículas de agregados e as finas películas de ligante quando estes materiais são submetidos às altas taxas de cisalhamento no misturamento e às grandes tensões de cisalhamento na compactação.

Segundo o produtor, o Revix ${ }^{\mathrm{TM}}$ é compatível com diferentes tipos de ligante, não alterando suas propriedades de consistência, e permite reduzir as temperaturas de usinagem e compactação da ordem de 35 a $45^{\circ} \mathrm{C}$, em relação a uma mesma mistura em temperatura convencional.

Os projetos de mistura com o Revix ${ }^{\mathrm{TM}}$ WMX têm sido realizados do mesmo modo que aqueles de misturas convencionais, havendo diferenças somente no que se refere à adição deste produto e à redução das temperaturas de usinagem. No mais, a incorporação do Revix ${ }^{\mathrm{TM}}$ WMX no processo de produção de mistura morna é simples e não requer alterações na planta de usina, podendo ser feita em gravimétricas ou drum-mixer. Por outro lado, há ainda a opção da usina já receber o ligante misturado a este aditivo diretamente do fornecedor de asfalto (PROWELL e HURLEY, 2007).

Nos Estados Unidos já existem algumas experiências de aplicação do Revix ${ }^{\mathrm{TM}}$ WMX em diferentes Estados. Verificam-se aplicações em que houve a incorporação de 15 a $30 \%$ de material fresado e o uso de asfalto modificado por polímero e ácido polifosfórico, segundo listado por Prowell e Hurley (2007). 


\subsection{REDUÇÃO DAS EMISSÕES}

\section{Emissões de gases de efeito estufa}

Conforme mencionado anteriormente, um grande impulso para o desenvolvimento das tecnologias de misturas mornas e semimornas ocorreu quando a União Europeia buscava formas de contribuir com a redução das emissões de gases de efeito estufa (GEE) ${ }^{5}$, de forma que as metas do Protocolo de Quioto pudessem ser atendidas (NEWCOMB, 2006; PROWELL e HURLEY, 2007).

A preocupação com as emissões de GEE se deve ao fato de que acredita-se que 0 aumento da temperatura média global do planeta desde meados do século 20 seja uma consequência do crescimento da concentração destes elementos na atmosfera por origem antropogênica (CGEE, 2008).

O dióxido de carbono $\left(\mathrm{CO}_{2}\right)$ é o principal gás de efeito estufa antropogênico, quando em 2004 representava $77 \%$ do total das emissões dos GEE deste tipo. A propósito, entre 1970 e 2004, as emissões de GEE em todo o mundo aumentaram cerca de $80 \%$, passando de 21 para 38 gigatoneladas de $\mathrm{CO}_{2}$ equivalente (IPCC, 2007). No Brasil, as emissões de GEE cresceram aproximadamente $60 \%$ entre 1990 e 2005, ano em que o país emitiu 2,2 gigatoneladas de $\mathrm{CO}_{2}$ equivalente. Todavia, em 2009, o Brasil registrou uma queda de $33,6 \%$ em relação a 2004 , ano com o maior nível de emissões desde 1990 (2,6 gigatoneladas), sobretudo devido à redução do desmatamento na Amazônia (FBMC, 2010).

E foi dentro deste contexto que, em 2005, entrou em vigor o Protocolo de Quioto, quando diversos países se comprometeram em reduzir as emissões de GEE em 5,2\% entre os anos de 2008 e 2012, considerando-se os níveis observados em 1990 (UNFCCC, 2005; CGEE, 2008; ROCHA, 2003). Todavia, como se sabia que muitos países industrializados teriam dificuldades em cumprir tal meta estabelecida no Protocolo de Quioto, foram propostos mecanismos de flexibilização, dentre os quais os mercados de carbono, dentro do Mecanismo de Desenvolvimento Limpo.

\footnotetext{
${ }^{5}$ Existe uma série de gases que são considerados GEE, mas os principais são dióxido de carbono $\left(\mathrm{CO}_{2}\right)$, metano $\left(\mathrm{CH}_{4}\right)$, óxido nitroso $\left(\mathrm{N}_{2} \mathrm{O}\right)$, hidrofluorcarbonos (HFCs), perfluorcarbonos (PFCs) e hexafluoreto de enxofre $\left(\mathrm{SF}_{6}\right)$. Os GEE diferem-se entre si quanto à sua influência no aquecimento do sistema climático global, devido às suas diferentes propriedades radioativas e tempos de vida na atmosfera. Para que as reduções de diferentes gases possam ser somadas, e os seus efeitos comparados, foi definida uma equivalência com $0 \mathrm{CO}_{2}$, que permite expressar as emissões de qualquer GEE em termos de toneladas de dióxido de carbono equivalente (CGEE, 2008).
} 
Neste sistema, a redução das emissões de GEE pode ser comercializada entre países por meio de Certificados de Emissões Reduzidas (CER). Assim, as cotas de carbono não emitidas ou retiradas da atmosfera por uma empresa de um país em desenvolvimento podem ser vendidas como créditos de carbono às empresas de países que tenham metas de diminuição (CGEE, 2008; ROCHA, 2003).

Como se sabe que a geração de energia pela queima de combustíveis fósseis (como petróleo, gás natural e carvão mineral) está entre as principais atividades humanas que emitem GEE, especialmente $\mathrm{CO}_{2}$ (CGEE, 2008; COOPER et al., 2000), as temperaturas mais baixas das misturas mornas e semimornas podem reduzir a emissão de tais poluentes, já que parte do combustível que seria utilizado no processo de mistura deixa de ser queimado. A propósito, a maior parte das emissões gasosas é resultado da combustão durante o processo de secagem e aquecimento dos agregados na usinagem (PROWELL e HURLEY, 2007).

Devido à diminuição das emissões de $\mathrm{CO}_{2}$ com as misturas mornas e semimornas, a pavimentação com estes materiais poderia ser inserida em projetos que se enquadrem no MDL, a partir de uma metodologia aprovada (como aquelas listadas em por UNFCCC, 2005) para a obtenção de créditos de carbono.

A literatura aponta alguns números que estariam relacionados à redução das emissões de $\mathrm{CO}_{2}$ quando da opção por misturas mornas ou semimornas. Rühl (2008), por exemplo, calcula que se na Alemanha são produzidas 60 milhões de toneladas de misturas asfálticas convencionais por ano, que por sua vez geram 1,5 milhão de tonelada de $\mathrm{CO}_{2}$, as misturas asfálticas mornas poderiam levar a uma diminuição de aproximadamente $10 \%$ dos níveis de $\mathrm{CO}_{2}$ por ano no país.

Já Olard (2008) comenta que na França a produção anual de misturas a quente é da ordem de 45 milhões de toneladas, sendo realizada em usinas movidas a gás natural (40\%) e a diesel (60\%). Assim, sabendo-se que as emissões de $\mathrm{CO}_{2}$ em usinas a gás natural são de cerca de $200 \mathrm{~kg} / \mathrm{MWh}$ e em usinas a diesel são de aproximadamente $270 \mathrm{~kg} / \mathrm{MWh}$, no caso da tecnologia semimorna $\mathrm{LEA}^{\circledR}$, por exemplo, que permite reduzir estes níveis em cerca de $9,7 \mathrm{~kg} / \mathrm{t}$, as emissões de $\mathrm{CO}_{2}$ seriam diminuídas em cerca de 450.000 toneladas por ano.

Hassan (2009) estudou o ciclo de vida de uma mistura morna WAM-Foam ${ }^{\circledR}$, em comparação com uma mistura a quente, e chegou à conclusão de que a primeira mostrou menores impactos ambientais no que se refere à poluição do ar, 
esgotamento de combustíveis fósseis e formação de "smog"6, pois foram observados decréscimos de 24\%, $18 \%$ e 10\%, respectivamente. No geral, verificou-se que a utilização da mistura morna implicou em uma redução de 15\% nos impactos ambientais em relação à mistura a quente.

Entretanto, além da temperatura, o tipo e o nível de emissão de poluentes em usina também dependem de outros fatores, como combustível utilizado, tipo de usina, teor de umidade dos agregados e utilização ou não de material asfáltico fresado (PROWELL e HURLEY, 2007). Do mesmo modo, o tipo de agregado pode ter grande impacto nas emissões de $\mathrm{CO}_{2}$ em uma usina, pois sua propriedade de calor específico pode variar muito entre materiais de pedreiras diferentes, mesmo que ambos tivessem densidades similares e fossem classificados, por exemplo, como granito. Isto foi observado em um estudo desenvolvido por Hamzah et al. (2010), com misturas mornas tipo Sasobit ${ }^{\circledR}$ (1 a 4\%), com três agregados de origem calcária e três do tipo granito, cujos resultados são apresentados na Figura 16.

\footnotetext{
${ }^{6}$ A palavra Smog é a junção das duas palavras da língua inglesa "smoke" e "fog", sendo este um fenômeno caracterizado por episódios em que a visibilidade atmosférica fica parcialmente obstruída por uma névoa de partículas sólidas e/ou aerossóis líquidos (BAIRD, 1999).
} 

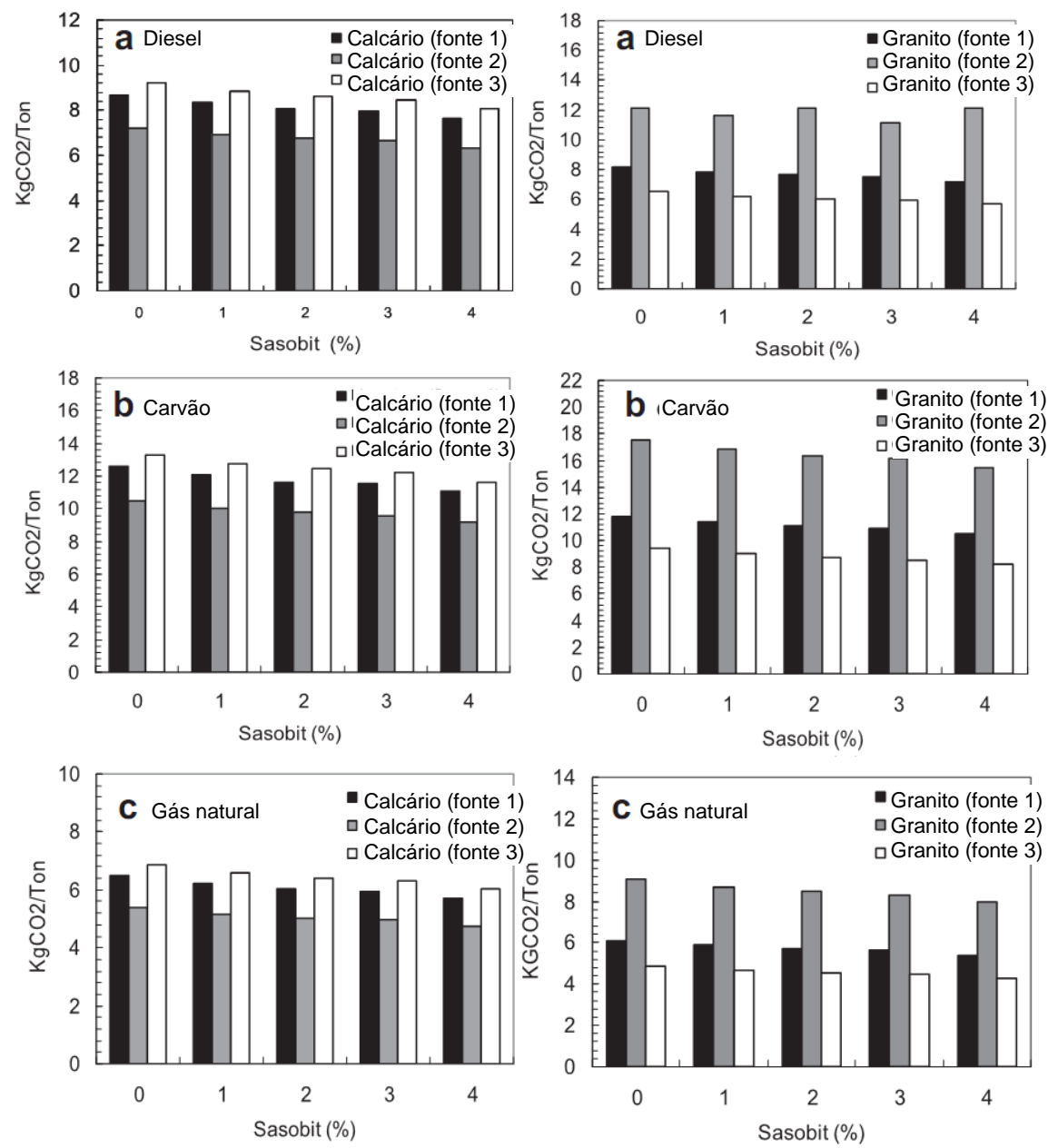

Figura 16 - Variação das emissões de $\mathrm{CO}_{2}$ em função do tipo de agregado retirado e adaptado de Hamzah et al. (2010)

\section{Emissões asfálticas}

O processo de pavimentação asfáltica ainda envolve um outro tipo de emissão que é de importante consideração, e no qual será dado mais enfoque no presente trabalho: as emissões asfálticas.

De acordo com Bernucci et al. (2008), o asfalto para pavimentação é um produto geralmente obtido a partir da destilação do petróleo, sendo constituído de 90 a $95 \%$ de hidrocarbonetos e de 5 a $10 \%$ de outros elementos, podendo ser comercializado e utilizado tal qual é produzido, ou ainda ser modificado ou misturado a outras substâncias, como borracha de pneu moído ou polímero, por exemplo.

Ao serem aquecidos tais produtos asfálticos emitem vapores (visivelmente percebidos em temperaturas de cerca de $150^{\circ} \mathrm{C}$, segundo Bernucci et al., 2008) que, 
em contato com o ar mais frio se condensam, tornando-se então fumos de asfalto. A composição química dos vapores e fumos de asfalto é variável e depende de alguns fatores como origem do petróleo, tipo de ligante, tempo/velocidade de usinagem e nível de temperatura ( $\mathrm{NIOSH}, 2000)$, mas sabe-se que estes elementos contêm poluentes $^{7}$ na forma de material particulado e de gases (GAUDEFROY et al., 2008; LA ROCHE et al., 2008).

De acordo com Baird (1999), o material particulado engloba um conjunto de poluentes sólidos e líquidos, que se mantém suspenso na atmosfera devido à sua pequena dimensão, com diâmetros que variam entre cerca de $0,002 \mu \mathrm{m}$ a $100 \mu \mathrm{m}$ (para se ter uma ideia, moléculas gasosas tipicamente tem dimensão de 0,0001 a $0,001 \mu \mathrm{m})$. De fato, existem muitas nomenclaturas para partículas atmosféricas, como poeiras (1 a $10.000 \mu \mathrm{m})$, fumaça $(0,1$ a $1 \mu \mathrm{m})$, fumos $(0,03$ a 10,0 $\mu \mathrm{m})$ e cinzas $(1,0$ a $1.000 \mu \mathrm{m})$, que normalmente se referem às partículas sólidas, enquanto que névoa, spray e fog $(0,01$ a $100 \mu \mathrm{m})$ geralmente estão associadas às partículas líquidas. No todo, as partículas sólidas ou líquidas dispersas ao ar e com diâmetro menor que $100 \mu \mathrm{m}$ são denominadas aerossóis (BAIRD, 1999).

Nos monitoramentos da qualidade do ar, a concentração de particulados pode ser apresentada como partículas totais em suspensão (PTS), congregando todos os aerossóis. No caso das partículas grossas (diâmetro entre 2,5 e $10 \mu \mathrm{m}$ ) de PTS, quando estas são inaladas, o nariz e a garganta ainda são capazes de filtrá-las de maneira eficiente, geralmente não permitindo que cheguem aos pulmões. Mas quando se trata de partículas finas (diâmetro até 2,5 $\mu \mathrm{m}$ ), normalmente estas conseguem chegar aos pulmões, podendo ser adsorvidas nas superfícies celulares e causando danos à saúde (BAIRD, 1999).

Por outro lado, na fase gasosa dos poluentes advindos das emissões asfálticas têm-se os compostos orgânicos voláteis (COVs), como citam Gaudefroy et al. (2008). A propósito, sabe-se que os derivados de petróleo são responsáveis pela emissão de quantidades significativas destes elementos (COOPER et al. 2000).

Os COVs são compostos que se volatilizam facilmente à pressão atmosférica, pois possuem ponto ebulição de até $130^{\circ} \mathrm{C}$, e contribuem na formação de oxidantes

\footnotetext{
${ }^{7}$ Segundo a CETESB, "considera-se poluente qualquer substância presente no ar, que pela sua concentração possa torná-lo impróprio, nocivo ou ofensivo à saúde, causando inconveniência ao bem estar público, danos aos materiais, à fauna e à flora, sendo prejudicial à segurança, ao uso e gozo da propriedade $e$ às atividades normais da comunidade" (Informação disponível em $<$ http://www.cetesb.sp.gov.br>. Acesso em: 30 abr. 2011).
} 
fotoquímicos, pois reagem com os $\mathrm{NO}_{x}$ na atmosfera e levam à formação de ozônio (BAIRD, 1999; CONAMA, 2006). Além disso, alguns COVs são ainda considerados tóxicos ou carcinogênicos (COOPER et al. 2000).

Os COVs somados aos aerossóis orgânicos (particulados) formam o grupo dos chamados compostos orgânicos totais (COTs). O nível de emissões asfálticas de COTs pode ser influenciado pela agitação a que o material asfáltico é submetido. Isto pôde ser verificado em um estudo laboratorial desenvolvido por La Roche et al. (2008), onde se notou que a intensidade das emissões de COTs aumentou à medida que a velocidade de misturamento também foi incrementada. Os autores atribuem esta ocorrência ao fato de que o processo de agitação leva à uma movimentação interna do asfalto, fazendo com que hajam trocas entre o ar e o ligante quente na interface destes, que seria o local onde a volatilização dos COTs ocorre. Com o tempo, o montante de COTs emitidos se exaure sob as altas temperaturas, mas quanto mais rápida for a agitação do asfalto, mais rápido isto ocorrerá.

O nível de emissões de COTs também pode ser influenciado pelo tipo de mistura asfáltica em função da granulometria, como foi observado em ensaios laboratoriais realizados por Gaudefroy et al. (2008). Confrontando-se, por exemplo, um concreto asfáltico denso com uma mistura de graduação SMA, isto poderia realmente ser evidenciado, já que o primeiro tipo de mistura geralmente requer teores de ligante entre 4,5 e 6\%, enquanto no segundo já é necessário adicionar de 6,0 a 7,5\% de asfalto (BERNUCCl et al., 2008). Gaudefroy et al. (2008) compararam duas misturas com graduações diferentes, com teores de ligante de 3,75 e 5,1\%, e notaram que a mistura mais pobre em ligante emitiu menos COTs. Os autores acreditam que os resultados obtidos estão associados à espessura de filme asfáltico em torno dos agregados, pois a perda de componentes voláteis é fortemente controlada por difusão e uma camada mais fina de ligante favoreceria a emissão dos compostos orgânicos.

Com relação a limites recomendáveis de exposição às emissões asfálticas, pode haver variações, especialmente por não se saber exatamente quais são os reais efeitos dos poluentes em humanos e, assim, as legislações podem ser mais restritivas em um local em relação a outro. Em 1977, nos Estados Unidos, o NIOSH fez uma revisão dos dados disponíveis na época sobre a exposição ocupacional ao asfalto e aos seus fumos e verificou que os principais efeitos adversos à saúde eram irritação das membranas do revestimento ocular e das mucosas do trato respiratório. 
Além disso, embora algumas evidências obtidas em estudos com animais tivessem indicado que $o$ asfalto mantido sobre a pele por longos períodos de tempo poderia resultar em carcinomas localizados, não havia relatos comparáveis de tais efeitos, advindos dos asfaltos e de seus fumos, em humanos. Com isto, o NIOSH recomendou que a exposição ocupacional a estes elementos fosse controlada, de forma que os operários não ficassem sujeitos às PTS em uma concentração maior do que $5 \mathrm{mg} / \mathrm{m}^{3}$ de ar (chamado de REL - em inglês, recommended exposure limit), amostrada em um período de 15 min. Cabe mencionar que a definição do REL se baseou somente nas PTS pelo fato de não haverem mais dados até então (NIOSH, 2000).

Mas nos Estados Unidos tem-se ainda um outro limite de exposição aos fumos de asfalto, que foi definido pela United States American Conference of Government Industrial Hygienists (ACGIH). Esta organização limita a $0,5 \mathrm{mg} / \mathrm{m}^{3}$ o tempo médio ponderado de exposição, particularmente das frações inaláveis que são solúveis em benzeno (SCHREINER, 2011). Segundo Ekström et al. (2001), os fumos de asfalto são completamente solúveis em benzeno, enquanto as PTS incluem todo material particulado coletado em filtros, como as poeiras da atmosfera, as partículas emitidas por queima de combustível em veículos, os próprios fumos de asfalto na fase aerossol, etc. O material solúvel em benzeno pode compor entre $10 \mathrm{a}$ $100 \%$ das PTS, dependendo do tipo de aplicação do asfalto e das condições do local, mas a maioria das obras de pavimentação produz níveis de emissão menores que $0,3 \mathrm{mg} / \mathrm{m}^{3}$.

Já na Alemanha, em 2000, foi estabelecido que $10 \mathrm{mg} / \mathrm{m}^{3}$ seria o limite aceitável de emissões de aerossóis e de gases advindos dos asfaltos. Entretanto, cabe salientar que enquanto o limite alemão considera aerossóis e gases, sem qualquer tolerância de variação destes dois componentes com a temperatura, o limite norte-americano se refere somente à fração de aerossóis (RÜHL, 2008).

O que se sabe é que ainda não existe um protocolo internacional para amostragem e análise dos fumos provenientes de asfalto aquecido e, assim, regiões/países/companhias acabam usando diferentes procedimentos, o que dificulta a comparação de resultados. Dentro deste contexto, ainda que a ACGIH, por exemplo, limite a fração particulada inalável dos fumos de asfalto somente com base no material captado em filtros, muitas vezes as análises laboratoriais também empregam material adsorvente para coletar os compostos voláteis que passam ou 
são removidos do filtro, já que a quantificação dos COTs é importante na avaliação dos compostos hidrocarbonetos presentes nos fumos de asfalto que causam irritação (EKSTRÖM et al., 2001).

Em termos regulatórios, atualmente o asfalto não é classificado como carcinogênico por nenhuma agência regulatória ou por outros órgãos científicos, mas segundo Schreiner (2011), a International Regulatory Agency for Research on Cancer (IARC) irá fazer uma reavaliação em breve.

Para fins de ilustração, a Figura 17 mostra resumidamente, de maneira esquemática, como ocorrem as emissões asfálticas a partir da usinagem de uma mistura.

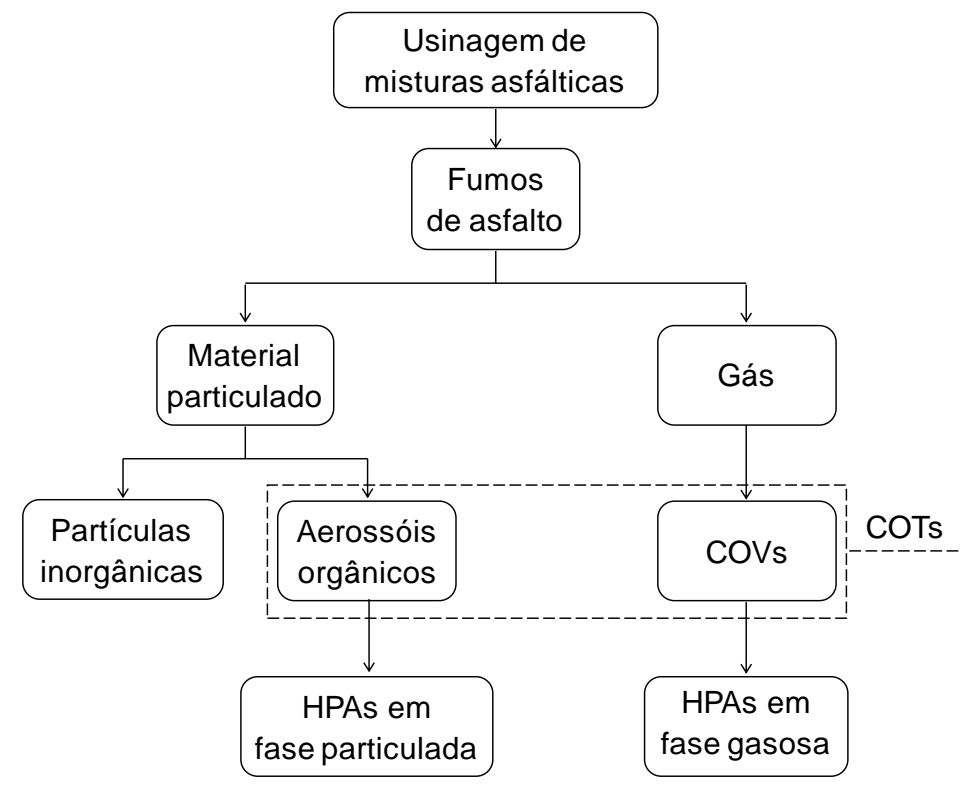

Figura 17 - Esquema de emissões asfálticas durante a usinagem retirado e adaptado de Gaudefroy et al. (2008)

Como é possível observar na Figura 17, as emissões asfálticas contêm hidrocarbonetos policíclicos aromáticos (HPAs). Os HPAs são resultado da combustão incompleta ou pirólise de materiais que contêm carbono e hidrogênio, possuindo ativa participação na formação de smog ${ }^{6}$ (BAIRD, 1999). Estes compostos estão amplamente distribuídos no ar (ainda que constituam apenas cerca de $0,1 \%$ do material particulado atmosférico), mas sua concentração em áreas urbanas é tipicamente da ordem de alguns nanogramas por metro cúbico, embora essa quantidade possa chegar a ser dez vezes maior em ambientes muito poluídos (BAIRD, 1999). 
Alguns compostos de HPAs são suspeitos de serem mutagênicos ou carcinogênicos (NIOSH, 2000; RAVINDRA et al., 2008; YASSAA et al., 2001; FERNANDES et al., 2009), mas ainda que não se tenham evidências consistentes de tais efeitos nocivos no ambiente ocupacional, não se pode excluir o risco carcinogênico destes elementos nestes locais (NIOSH, 2000).

Os HPAs são compostos orgânicos que possuem dois ou mais anéis de benzeno fundidos, e constituem um dos primeiros poluentes atmosféricos identificados como possíveis carcinogênicos. Considerando-se sua estrutura física, à medida que o peso molecular aumenta (maior número de anéis aromáticos), a carcinogenicidade dos HPAs também cresce (RAVINDRA et al., 2008). No contexto da pavimentação asfáltica, um aspecto interessante dos HPAs mais pesados é a contribuição que estes podem dar às propriedades físicas do ligante, ao influenciar na flexibilidade do asfalto quando se apresentam em grandes concentrações neste último (PINHEIRO et al., 2009).

Como existem preocupações com os efeitos negativos que os HPAs podem ter em humanos, a Agency for Toxic Substances and Disease Registry (ATSDR) dos Estados Unidos listou 17 HPAs com base em seu perfil toxicológico, que foram classificados como prioritários, embora os efeitos de cada HPA na saúde não sejam exatamente iguais. Estes 17 compostos foram escolhidos para a inclusão na lista de prioritários porque: (i) existem mais informações sobre estes HPAs do que sobre outros; (ii) se suspeita que estes HPAs sejam mais prejudiciais do que outros, ainda que estes efeitos danosos também sejam representativos dos HPAs em geral; (iii) existe uma chance maior de exposição a estes HPAs do que a outros; e (iv) de todos os HPAs analisados, estes exibem as maiores concentrações (RAVINDRA et al., 2008). A Figura 18 apresenta os 17 HPAs prioritários listados pela ATSDR. Cabe mencionar que, com exceção do benzo[j]fluoranteno, a United States Environmental Protection Agency (USEPA) também considera tais HPAs como prioritários (RAVINDRA et al., 2008). No mais, o benzo[a]pireno é o mais notório HPA, conhecido como cancerígeno (BAIRD, 1999; RAVINDRA et al., 2008). 


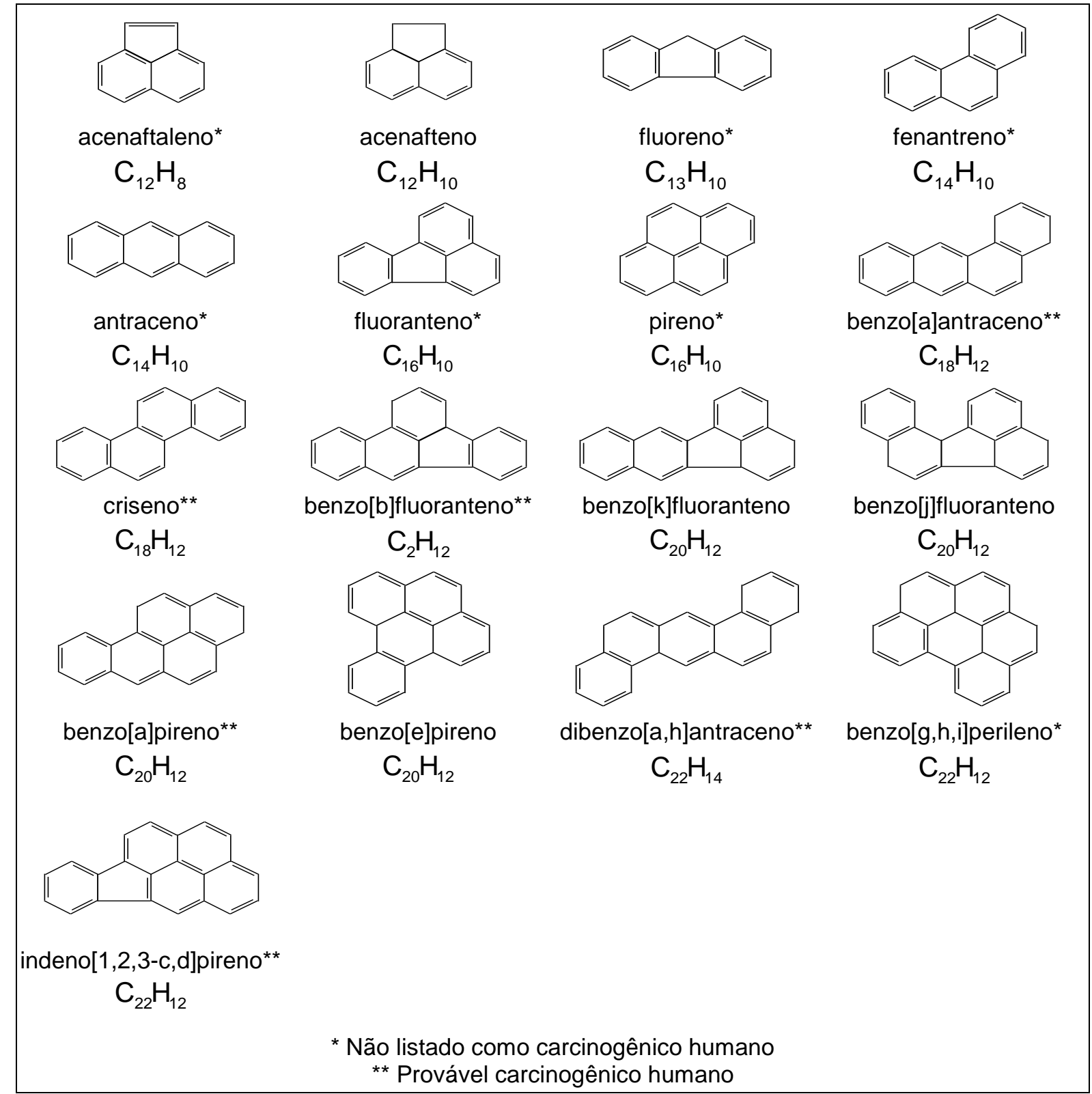

Figura 18 - HPAs prioritários, segundo ATSDR e USEPA retirado e adaptado de Ravindra et al. (2008)

Os HPAs podem se apresentar como gases ou adsorvidos em material particulado, como mostra a Tabela 2 onde estão indicadas certas propriedades físico-químicas de alguns dos HPAs prioritários. Observa-se que, no geral, os HPAs mais pesados possuem baixa pressão de vapor ${ }^{8}$, e é por isso que estes compostos costumam não resistir por muito tempo na atmosfera como moléculas gasosas, pois acabam se condensando e sendo adsorvidos nas superfícies de material particulado sólido (BAIRD, 1999).

\footnotetext{
${ }^{8}$ De acordo com Cooper e Alley (2002), a pressão de vapor é uma medida da tendência de escape ou volatilidade de um líquido, aumentando rapidamente com o incremento de temperatura.
} 
Tabela 2 - Propriedades físico-químicas de alguns HPAs (retirado de Santos, 2010)

\begin{tabular}{cccccc}
\hline HPA & $\begin{array}{c}\text { Número } \\
\text { de } \\
\text { anéis }\end{array}$ & Fase ${ }^{*}$ & $\begin{array}{c}\text { Massa } \\
\text { molecular } \\
{[\mathrm{g} / \mathrm{mol}]}\end{array}$ & $\begin{array}{c}\text { Ponto de } \\
\text { ebulição } \\
{\left[{ }^{\circ} \mathrm{C}\right]}\end{array}$ & $\begin{array}{c}\text { Pressão } \\
\text { de vapor } \\
{[\mathrm{Pa}]}\end{array}$ \\
\hline Fenantreno & 3 & $\mathrm{P} / \mathrm{G}$ & 178 & 340 & $1,6 \times 10^{-2}\left(25^{\circ} \mathrm{C}\right)$ \\
\hline Antraceno & 3 & $\mathrm{P} / \mathrm{G}$ & 178 & 342 & $8,9 \times 10^{-4}\left(25^{\circ} \mathrm{C}\right)$ \\
\hline Fluoranteno & 4 & $\mathrm{P} / \mathrm{G}$ & 202 & 375 & $1,2 \times 10^{-3}\left(25^{\circ} \mathrm{C}\right)$ \\
\hline Pireno & 4 & $\mathrm{P} / \mathrm{G}$ & 202 & 393 & $6,0 \times 10^{-4}\left(25^{\circ} \mathrm{C}\right)$ \\
\hline Benzo[a]antraceno & 4 & $\mathrm{P}$ & 228 & 400 & $2,8 \times 10^{-5}\left(25^{\circ} \mathrm{C}\right)$ \\
\hline Criseno & 4 & $\mathrm{P}$ & 228 & 448 & $8,4 \times 10^{-5}\left(20^{\circ} \mathrm{C}\right)$ \\
\hline Benzo[b]fluoranteno & 5 & $\mathrm{P}$ & 252 & 481 & $6,7 \times 10^{-5}\left(20^{\circ} \mathrm{C}\right)$ \\
\hline Benzo[k]fluoranteno & 5 & $\mathrm{P}$ & 252 & 480 & $1,3 \times 10^{-8}\left(20^{\circ} \mathrm{C}\right)$ \\
\hline Benzo[a]pireno & 5 & $\mathrm{P}$ & 252 & 496 & $7,3 \times 10^{-7}\left(20^{\circ} \mathrm{C}\right)$ \\
\hline Dibenzo[a,h]antraceno & 5 & $\mathrm{P}$ & 278 & 524 & $1,3 \times 10^{-8}\left(20^{\circ} \mathrm{C}\right)$ \\
\hline Benzo[g,h,i]perileno & 6 & $\mathrm{P}$ & 276 & 545 & $1,4 \times 10^{-8}\left(20^{\circ} \mathrm{C}\right)$ \\
\hline Indeno[1,2,3-cd]pireno & 6 & $\mathrm{P}$ & 276 & 536 & $1,3 \times 10^{-8}\left(20^{\circ} \mathrm{C}\right)$ \\
\hline${ }^{*} \mathrm{P} / \mathrm{G}=$ particulada e gasosa & & & & & \\
$\mathrm{P}=$ particulada & & & & &
\end{tabular}

Como os dados referentes ao potencial carcinogênico dos HPAs presentes em fumos de asfalto ainda são limitados e as emissões asfálticas são dependentes de diversos fatores (como citado anteriormente), é importante que sejam desenvolvidas pesquisas que contribuam para um maior entendimento das questões relativas às emissões de HPAs advindas de materiais asfálticos.

Gaudefroy et al. (2008) verificaram, em laboratório, que o tempo de usinagem interfere nas emissões de HPAs, pois estabeleceram um tempo de mistura de 30 min para efeito de observação e notaram que o dibenzo[a,h]antraceno, por exemplo, só foi detectado após 20 min de usinagem, quando os níveis de emissão de naftaleno já estavam em queda. Neste caso, os autores concluíram então que à medida que os HPAs apresentem menor ponto de ebulição, sua emissão ocorre mais rápida e em maior quantidade.

A temperatura é um fator crucial no controle das emissões asfálticas (GASTHAUER et al., 2008), pois a temperatura em que os fumos são gerados afeta a proporção relativa de cada HPA nestes fumos, bem como a quantidade de vapores emitidos, e estes são fatores que influenciam nos níveis de exposição e no potencial toxicológico destes elementos (SCHREINER, 2011).

Deste modo, as misturas mornas e semimornas podem contribuir com a redução da exposição ocupacional, tanto aos odores quanto às emissões, 
principalmente porque, segundo NIOSH (2000), acredita-se que os fumos asfálticos gerados em altas temperaturas sejam mais suscetíveis à formação de HPAs carcinogênicos do que os fumos produzidos em temperaturas mais amenas.

De acordo com Prowell e Hurley (2007), uma pesquisa realizada pelo NCAT sobre o efeito da temperatura nas emissões e odores mostrou que, de fato, a temperatura é um fator que afeta significativamente na quantidade e na composição química dos fumos. Este e outros estudos verificaram que mesmo uma pequena redução na temperatura de usinagem (em cerca de $6^{\circ} \mathrm{C}$ ) já permite uma diminuição perceptível na geração de fumos e de odores. Neste sentido, como a maior parte das técnicas de misturas mornas é capaz de reduzir as temperaturas de usinagem e compactação da ordem de $30^{\circ} \mathrm{C}$ em relação às misturas convencionais, a diminuição da geração de fumos pode ser verficada de maneira muito significativa. Isto é visualmente perceptível na Figura 19, onde têm-se fotos apresentadas por Barthel et al. (2004) relativas a uma obra francesa com a aplicação em campo de uma mistura a quente $\left(150^{\circ} \mathrm{C}\right)$ e de uma mistura morna tipo Aspha-Min ${ }^{\circledR}\left(120^{\circ} \mathrm{C}\right)$.
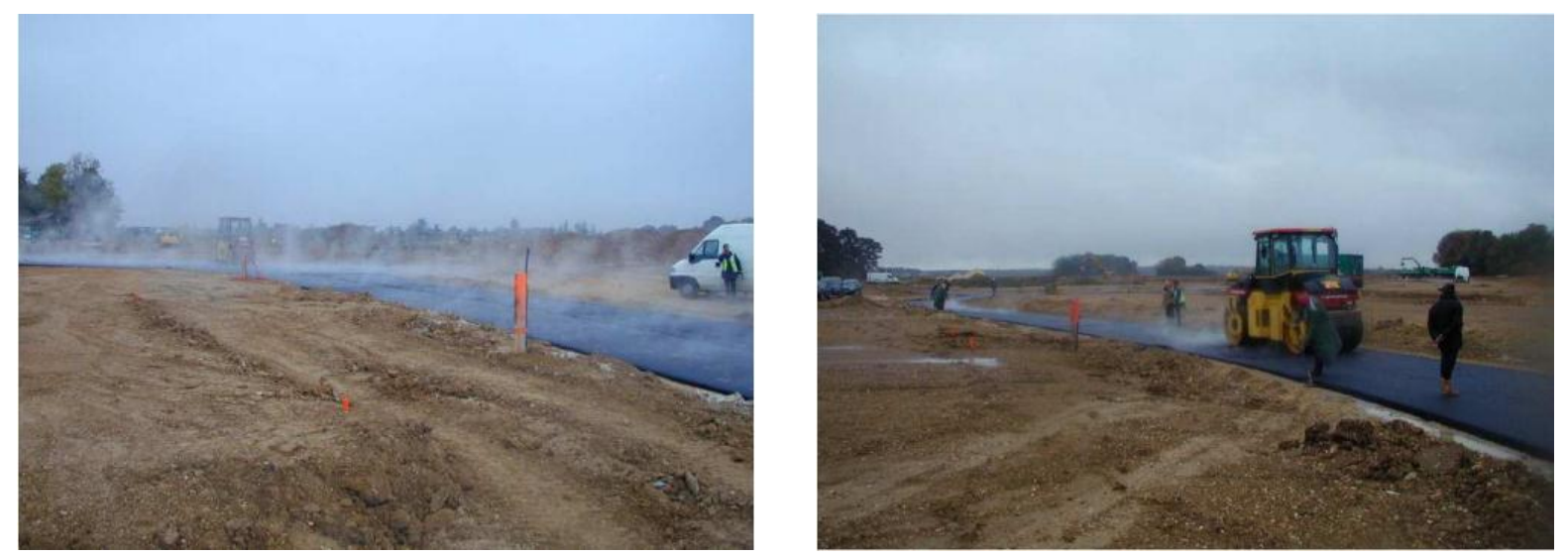

Figura 19 - Vapores e fumos de asfalto com a aplicação de uma mistura a quente a $150^{\circ} \mathrm{C}$ e de uma mistura morna Aspha-Min ${ }^{\circledR}$ a $120^{\circ} \mathrm{C}$ à esquerda e à direita, respectivamente retirado de Barthel et al. (2004)

Com relação ao material particulado, Prowell e Hurley (2007) falam de um projeto norte-americano envolvendo três tipos de misturas mornas (Aspha-Min ${ }^{\circledR}$, Evotherm $^{\mathrm{TM}}$ e Sasobit ${ }^{\circledR}$ ), em comparação com uma mistura convencional, em que um dos objetivos era analisar e comparar as emissões de PTS durante a aplicação em campo. Com uma redução de temperatura entre 29 e $43^{\circ} \mathrm{C}$ nas misturas mornas, os resultados mostraram que houve uma queda média entre 67 e 77\% das PTS em relação à mistura a quente. 
No Brasil, também existe uma experiência de monitoramento de campo das emissões de material particulado advindas da aplicação de uma mistura morna e de uma mistura convencional. Neste estudo, apresentado por Cravo (2010), a mistura morna foi preparada com o aditivo A-SAT da Petrobras, que se baseia em espumejo do asfalto. As obras em questão foram realizadas na Cidade Universitária do Rio de Janeiro e a coleta do material particulado durante a exposição ocupacional se deu a partir da instalação de filtros/bombas nos trabalhadores (Figura 20) com diferentes funções na pavimentação. Os resultados mostraram que, à exceção do motorista da vibroacabadora, os demais profissionais estiveram igualmente ou menos expostos ao material particulado na mistura morna (Figura 21).

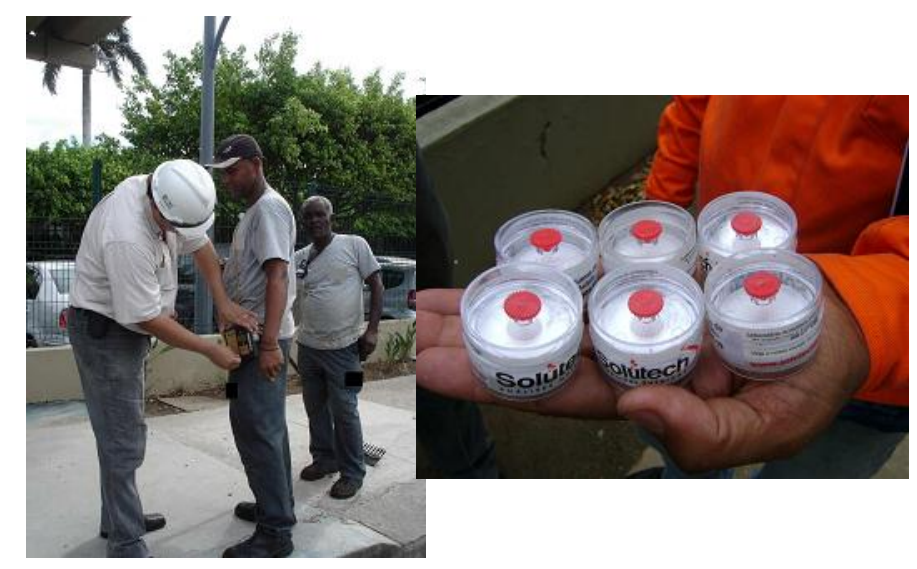

Figura 20 - Instalação de filtro para a medida de exposição ocupacional ao material particulado em obra com misturas a quente e morna no Rio de Janeiro retirado de Cravo (2010)

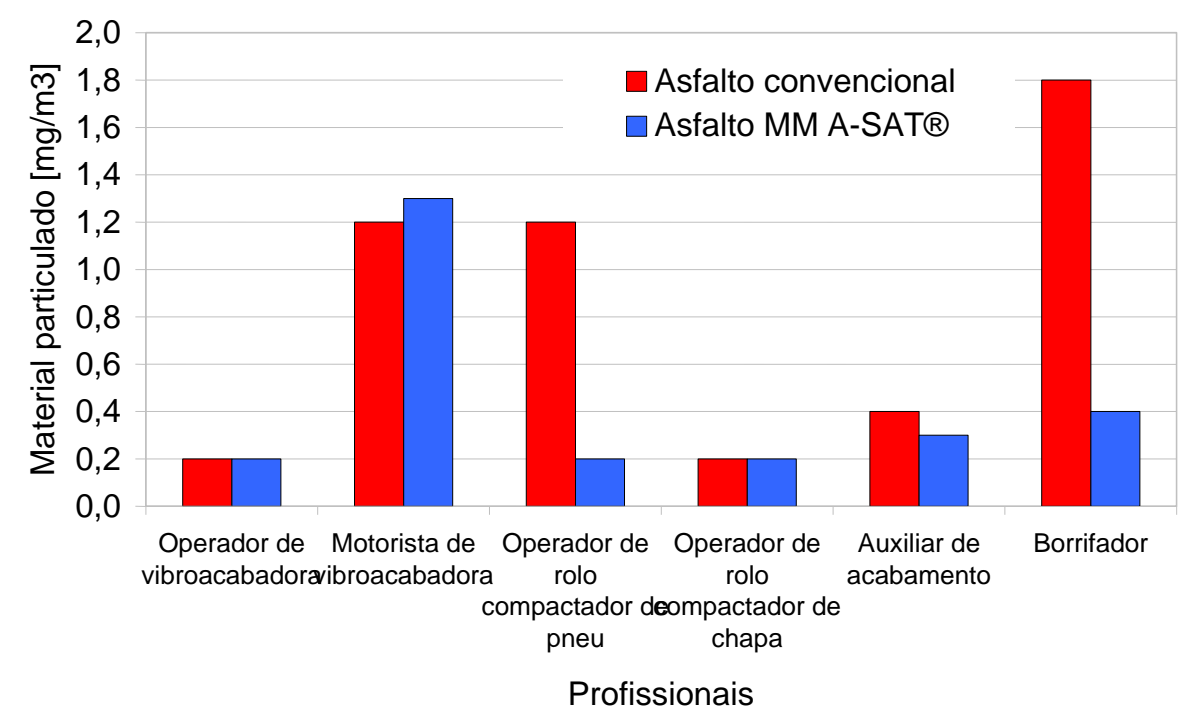

Figura 21 - Resultados de medidas de exposição ocupacional ao material particulado em obra com mistura morna e mistura a quente no Rio de Janeiro retirado e adaptado de Cravo (2010) 


\subsection{REDUÇÃO DO CONSUMO ENERGÉTICO}

O uso de misturas mornas e semimornas também se faz interessante pelo seu potencial de redução do consumo de energia no processo de usinagem, principalmente tendo-se em vista a elevação dos preços do petróleo nos últimos anos. Isto reflete o aumento constante da demanda e o temor do esgotamento das reservas de combustíveis fósseis, particularmente do petróleo, que atualmente é a principal fonte de energia (HAMZAH et al., 2010). Para fins de ilustração, a Figura 22 apresenta o aumento do preço do petróleo ao longo dos últimos anos no "Basket Price" ${ }^{\text {"9 }}$ da Organização dos Países Exportadores de Petróleo (OPEP). A propósito, de acordo com Hassan (2009), o encarecimento da energia e dos derivados de petróleo tem influenciado a alta dos preços do setor de construção, ainda com previsão de que a atual crise energética tenda a piorar à medida que a demanda por energia ultrapasse a taxa de extração de petróleo.

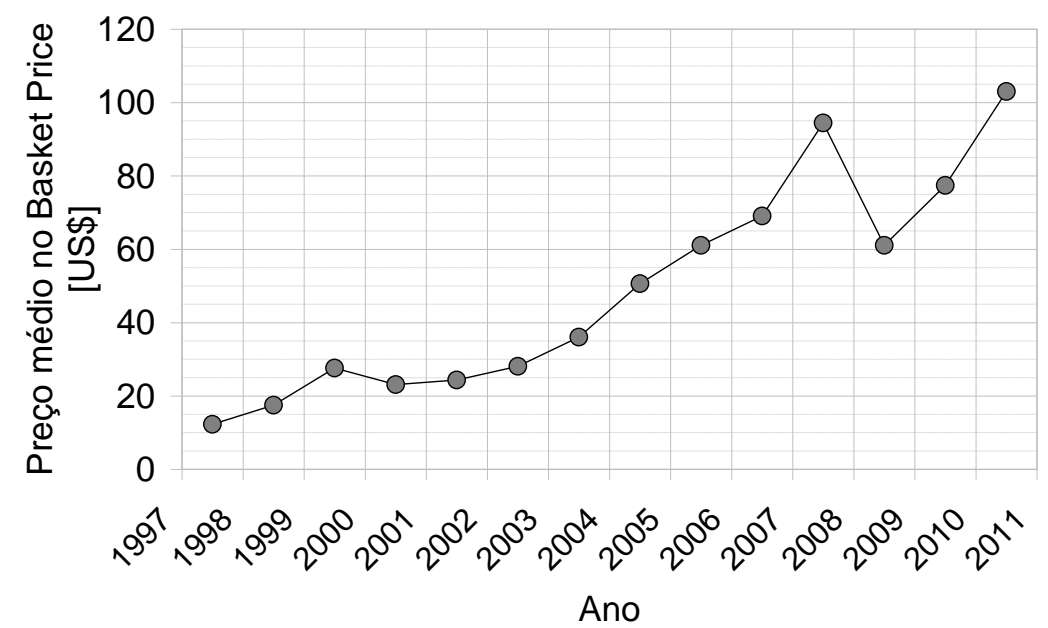

Figura 22 - Variação anual do preço médio do petróleo no "Basket Price" da OPEP, em dólares americanos

retirado e adaptado de www.opec.org

Sabe-se que a secagem/vaporização d'água/aquecimento dos agregados em usina é uma etapa que demanda grande consumo de energia, principalmente se o agregado estiver com teor de umidade mais elevado, com o gasto de combustível

\footnotetext{
${ }^{9}$ O "Basket Price" da OPEP foi introduzido em 2005, e consiste em uma média de preços dos seguintes óleos crus: Saharan Blend (Argélia), Girassol (Angola), Oriente (Equador), Iran Heavy (Irã), Basra Light (Iraque), Kuwait Export (Kuwait), Es Sider (Líbia), Bonny Light (Nigéria), Qatar Marine (Qatar), Arab Light (Arábia Saudita), Murban (Emirados Árabes Unidos) and Merey (Venezuela).
} 
aumentando em $10 \%$ para cada $1 \%$ a mais de água nos agregados (PROWELL e HURLEY, 2007).

Com a redução da temperatura dos agregados nas tecnologias de misturas mornas e semimornas é possível diminuir a quantidade de energia utilizada. Segundo Prowell e Hurley (2007), diversos projetos com misturas mornas até o momento já indicaram uma economia de combustível que tipicamente varia entre 20 a 35\% (e estes níveis poderiam ser ainda maiores se, em alguns casos, os queimadores da usina fossem ajustados para trabalhar adequadamente em níveis mais baixos de temperatura).

Barthel et al. (2004), por exemplo, relatam uma obra francesa com uma mistura morna tipo Aspha-Min ${ }^{\circledR}$, em comparação com uma mistura a quente, e calculam que houve uma redução de $30 \%$ no consumo de energia. Assim, se uma usina normalmente utiliza $8 \mathrm{~L}$ de óleo por tonelada de mistura asfáltica convencional, então passaria a consumir 5,6 L para a mistura morna, gerando uma economia de 2,4 L por tonelada. Este mesmo percentual foi verificado por Lecomte et al. (2007) em uma aplicação de mistura morna tipo WAM-Foam ${ }^{\circledR}$ na Itália.

A energia gasta para produzir uma mistura asfáltica pode ser calculada pela expressão (1), como feito por Hamzah et al. (2010), Romier et al. (2006) e Harder et al. (2008), que contempla o efeito da variação de temperatura na energia necessária para aquecer um determinado material, sem que este mude de estado.

$Q=\sum_{i=n}^{j=n-1} m_{m} \cdot C_{m} \cdot \Delta \theta$

Onde:

$\mathrm{Q}=$ energia, em $[\mathrm{J}]$

$\mathrm{m}_{\mathrm{m}}=$ massa de material $[\mathrm{kg}]$;

$\mathrm{c}_{\mathrm{m}}=$ calor específico do material $\left[\mathrm{J} / \mathrm{kg} /{ }^{\circ} \mathrm{C}\right]$;

$\Delta \theta=$ diferença entre as temperaturas ambiente e de mistura $\left[{ }^{\circ} \mathrm{C}\right]$.

Por outro lado, quando há mudança de estado físico, tendo-se em vista a situação de vaporização da água, o cálculo da energia requerida deve considerar o calor latente de vaporização (clv) e as massas inicial e final de vapor, como na expressão (2). 
$\mathrm{Q}=\operatorname{clv} \cdot \Delta \mathrm{m}_{\mathrm{v}}$

Onde:

$Q=$ energia, em [J];

clv = calor latente de vaporização $[\mathrm{J} / \mathrm{kg}]$

$\Delta \mathrm{m}_{\mathrm{v}}=$ diferença de massas de vapor inicial e final $[\mathrm{kg}]$.

Hamzah et al. (2010) avaliaram a diferença do consumo de combustível de misturas mornas com Sasobit ${ }^{\circledR}$ (em taxas de 1 a $4 \%$ ), em comparação com misturas convencionais, variando-se a fonte e o tipo de agregado (três origens de calcário e três origens de granito), além do tipo de combustível da usina (diesel, gás natural e carvão). Os autores verificaram que, no geral, pode haver uma economia de energia da ordem de 4 a $12 \%$, sendo que quanto maior o percentual do aditivo, maior a redução de combustível.

Uma economia mais expressiva foi observada por Romier et al. (2006), que calcularam a diferença de energia requerida para uma mistura semimorna tipo LEA $^{\circledR}$ em relação a uma mistura convencional. Os autores notaram que, considerando-se somente a secagem/vaporização d'água/aquecimento dos agregados e aquecimento do ligante, a economia de combustível seria de quase $50 \%$, já que o balanço energético indicou que seriam necessários $175 \mathrm{MJ} / \mathrm{t}$ na mistura a quente, enquanto que na mistura LEA ${ }^{\circledast}$ este consumo cairia para $83 \mathrm{MJ} / \mathrm{t}$.

Harder et al. (2008) foram ainda além e calcularam o gasto adicional de combustível devido a perdas térmicas a que o sistema está sujeito (que podem variar em função dos tipos de mistura asfáltica, de usina e de combustível empregados). As perdas térmicas ocorridas na usinagem de uma determinada instalação dependem basicamente da diferença de temperaturas ambiente e de trabalho, mas via de regra a usinagem de materiais a $160^{\circ} \mathrm{C}$ quando a temperatura ambiente é de $15^{\circ} \mathrm{C}$ causa uma perda térmica que é praticamente o dobro daquelas verificadas em uma usinagem a $90^{\circ} \mathrm{C}$, por exemplo. Os autores mencionam que algumas medidas realizadas em uma usina gravimétrica mostraram que o consumo de energia atribuído a tais perdas era da ordem de $3 \mathrm{~kg}$ de combustível (óleo) por tonelada de mistura, em uma usinagem ocorrida a $160^{\circ} \mathrm{C}$, sob uma temperatura ambiente de $15^{\circ} \mathrm{C}$ (embora as perdas térmicas também dependam de outros fatores como tipo de equipamento, tipo de secador, sistema de exaustão). Neste estudo foram avaliados seis tipos de mistura asfáltica, a saber: (1) mistura a quente de referência (ref.); (2) mistura morna com adição de cera ou agente de espumejo; (3) 
mistura morna com duplo recobrimento (como a WAM-Foam ${ }^{\circledR}$ ); (4) mistura semimorna com emulsão; (5) mistura semimorna com asfalto espumado; (6) mistura semimorna preparada a partir da separação das frações graúda e miúda, onde esta última entra úmida na usinagem (como a $L E A^{\circledR}$ ). Os resultados encontrados são apresentados na Figura 23, onde um gráfico mostra o consumo de combustível com cada material na usinagem (sem perdas) e o outro ilustra o gasto de energia somando-se as perdas (abaixo de cada coluna têm-se o consumo total de combustível e a economia de energia em relação à mistura de referência).
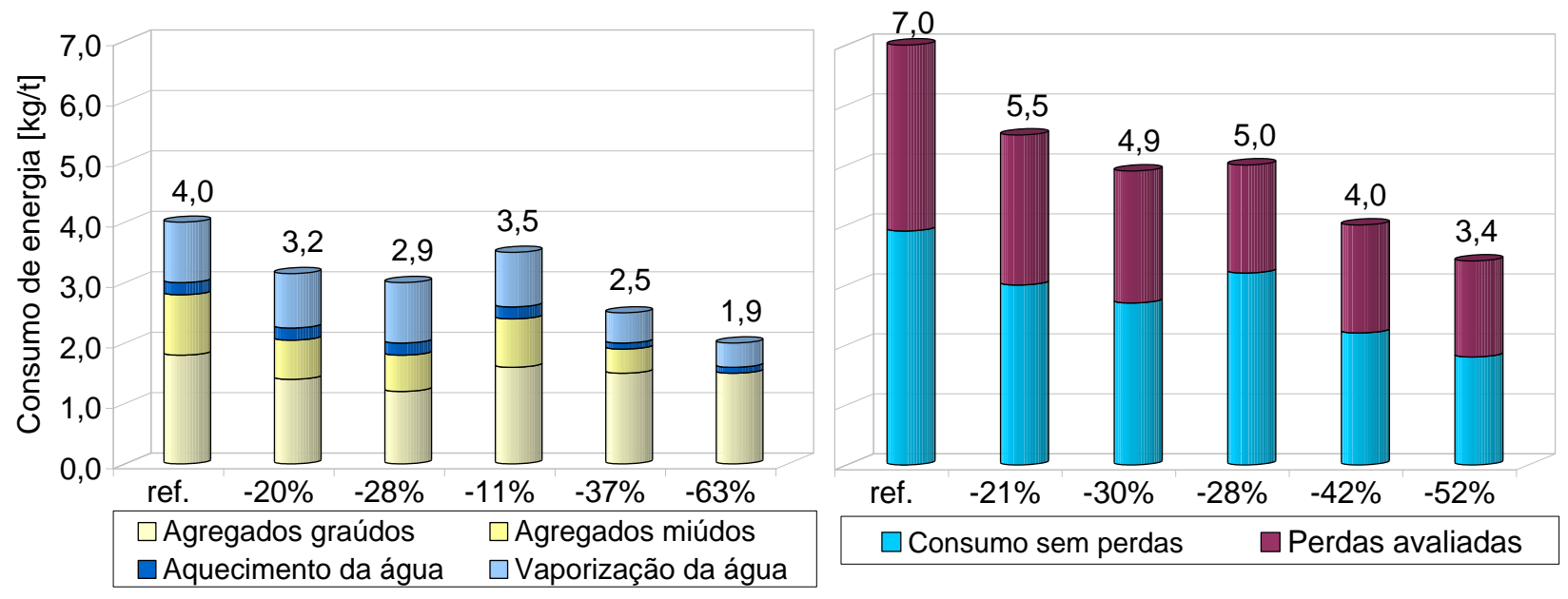

Figura 23 - Consumo de combustível, em usina, sem perdas térmicas e com perdas térmicas à esquerda e à direita, respectivamente retirado e adaptado de Harder et al. (2008)

Evidentemente, é necessário contrabalançar a redução do consumo de energia e de emissões de cada tecnologia de mistura morna e semimorna, somada à sua durabilidade, com os gastos necessários em cada caso (custo x benefício), para que sejam verificados os ganhos reais em cada situação, embora existam aspectos de difícil mensuração, como mencionado anteriormente.

A Tabela 3, extraída de Kristjánsdóttir et al. (2007), compara algumas características de quatro técnicas de misturas mornas com a economia de energia e aos gastos em cada situação. 
Tabela 3 - Comparativo de economia de energia e gastos com quatro tipos de mistura morna retirado e adaptado de Kristjánsdóttir et al. (2007)

\begin{tabular}{|c|c|c|c|c|}
\hline Tecnologia & WAM-Foam $^{\circledR}$ & Aspha-Min ${ }^{\circledR}$ & Sasobit $^{\circledR}$ & Evotherm ${ }^{\mathrm{TM}} \mathrm{ET}$ \\
\hline $\begin{array}{l}\text { Redução de temperatura* } \\
\text { indicada na literatura }\end{array}$ & 43 a $63^{\circ} \mathrm{C}$ & $30^{\circ} \mathrm{C}$ & 18 a $54^{\circ} \mathrm{C}$ & 50 a $75^{\circ} \mathrm{C}$ \\
\hline $\begin{array}{c}\text { Necessidade de } \\
\text { modificações na planta } \\
\text { da usina? }\end{array}$ & $\begin{array}{l}\text { Sim, para } \\
\text { espumejo }\end{array}$ & $\begin{array}{l}\text { Sim ou não, } \\
\text { dependendo de } \\
\text { como é a adição } \\
\text { do produto }\end{array}$ & $\begin{array}{l}\text { Sim ou não, } \\
\text { dependendo de } \\
\text { como é a adição } \\
\text { do produto }\end{array}$ & $\begin{array}{l}\text { Mínima, } \\
\text { se houver }\end{array}$ \\
\hline $\begin{array}{c}\text { Gastos com modificação } \\
\text { ou instalação de } \\
\text { equipamentos }\end{array}$ & $\begin{array}{c}U \$ 30.000 \mathrm{a} \\
\cup \$ 70.000\end{array}$ & $\begin{array}{c}\text { U\$ } 0 \text { a } \\
\text { U\$ } 40.000\end{array}$ & $\begin{array}{c}\text { U\$ } 0 \mathrm{a} \\
\text { U\$ } 40.000\end{array}$ & Mínima \\
\hline Royalties & $\begin{array}{c}\text { U\$ } 15.000\left(1^{\circ} \text { ano }\right) \\
\text { U\$ 5.000/usina/ano } \\
\text { U\$ 0,30/t }\end{array}$ & Nenhum & Nenhum & Nenhum \\
\hline Gasto com produto & Não há & U\$ $1,35 / \mathrm{kg}$ & U\$ $1,80 / \mathrm{kg}$ & $\begin{array}{c}7 \text { a } 10 \% \\
\text { a mais do que } \\
\text { um asfalto }\end{array}$ \\
\hline Dosagem recomendada & Não há & $\begin{array}{c}0,3 \% \text { em massa } \\
\text { de mistura }\end{array}$ & $\begin{array}{c}1,5 \text { a } 3 \% \text { em } \\
\text { massa de asfalto }\end{array}$ & $\begin{array}{l}\text { Substituto } \\
\text { do asfalto }\end{array}$ \\
\hline $\begin{array}{c}\text { Custo aproximado } \\
\text { da técnica por } \\
\text { tonelada de mistura }\end{array}$ & U\$ $0,33^{* *}$ & U\$ 3,96 & $\begin{array}{l}\text { U\$ } 1,43 a \\
\text { U\$ } 2,86\end{array}$ & $\begin{array}{l}\text { U\$ } 3,85 \mathrm{a} \\
\text { U\$ } 4,40\end{array}$ \\
\hline $\begin{array}{l}\text { Redução de emissões } \\
\text { indicada na literatura }\end{array}$ & 30 a $98 \%$ & 75 a $90 \%$ & - & 40 a $60 \%$ \\
\hline $\begin{array}{l}\text { Redução do consumo } \\
\text { de energia }\end{array}$ & 30 a $40 \%$ & $30 \%$ & $20 \%$ & 50 a $75 \%$ \\
\hline
\end{tabular}

${ }^{*}$ em relação a uma mistura convencional a $160^{\circ} \mathrm{C}$

${ }^{* *}$ sem incluir $01^{\circ}$ ano e os custos de royalties

Kristjánsdóttir et al. (2007) concluíram que, no geral, em lugares onde o custo do combustível é relativamente elevado (como por exemplo na Islândia ou no Estado norte-americano do Havaí), somente a diminuição do consumo energético já pode compensar a despesa relativa à mistura morna, se a redução for da ordem de $50 \%$. Caso contrário, a economia de energia pode não compensar sozinha os gastos com a mistura morna, mas o custo deve cair no futuro próximo com a popularização das tecnologias e com a superação contínua dos preços dos combustíveis sobre a inflação. Neste caso, as misturas mornas poderão se tornar mais econômicas levando-se em conta somente a questão da redução do consumo de energia, sem contar os demais ganhos.

Além disso, Kristjánsdóttir et al. (2007) também verificaram que, caso seja incluído material fresado na mistura morna, o custo de produção pode ser ainda menor, em relação a uma mistura convencional, devido ao reaproveitamento de material e à diminuição da quantidade de agregados virgens. Nesta avaliação, enquanto uma mistura morna com $50 \%$ de reciclados e $50 \%$ de material virgem custaria o equivalente a $\cup \$ 45,63$ por tonelada, o gasto com uma mistura tradicional 
com $100 \%$ de agregados virgens seria de U\$ 60,25 (significando uma economia de cerca de $24 \%$ ).

\subsection{ALGUNS ESTUDOS BRASILEIROS COM MISTURAS ASFÁLTICAS MORNAS E SEMIMORNAS}

Seguindo a tendência mundial, no Brasil também já é possível observar pesquisas relativas ao comportamento de misturas mornas preparadas sob diferentes tecnologias. Sousa Filho (2006), da Universidade Federal do Ceará, estudou as propriedades mecânicas de misturas mornas produzidas com um tipo de zeólita, em comparação com misturas convencionais $\left(165,168\right.$ e $\left.170^{\circ} \mathrm{C}\right)$, variandose o tipo de asfalto (CAP 50-70, CAP 30-45 e asfalto modificado por SBS), a temperatura de usinagem e compactação (redução de 20 e $30^{\circ} \mathrm{C}$ em relação à mistura a quente) e o teor de material zeolítico (0 a 1\%). Os resultados mostraram que não houve comprometimento dos parâmetros mecânicos das misturas mornas analisadas, verificados por meio de ensaios de resistência à tração e módulo de resiliência, comparativamente com as misturas de referência.

Rhode et al. (2008), da Universidade Federal do Rio Grande do Sul, apresentaram uma pesquisa realizada com uma mistura semimorna tipo $\mathrm{EBE}^{\circledR}$ $\left(100^{\circ} \mathrm{C}\right)$, com diferentes teores de água injetada na mistura (5, 8 e 10\%) e CAP 5070, confrontando suas propriedades mecânicas com uma mistura convencional. Os resultados mostraram que os parâmetros de resistência à tração, módulo de resiliência, desgaste Cantabro e resistência ao dano por umidade induzida se mostraram muito similares ao da mistura a quente $\left(160^{\circ} \mathrm{C}\right)$. Ademais, estes pesquisadores também avaliaram uma mistura morna com zeólitas $\left(110^{\circ} \mathrm{C}\right)$, conforme relatado em LAPAV/UFRGS e Concepa (2008), e observaram a mesma tendência de resultados. Comparando-se as misturas $E_{B E}{ }^{\circledR}$ e com zeólitas, os valores nos ensaios de resistência à tração foram iguais, enquanto o resultado de módulo de resiliência foi mais favorável na mistura com zeólitas (quase $1.000 \mathrm{MPa}$ maior).

Otto (2009), da Universidade Federal de Santa Catarina, divulgou um estudo de fadiga e de módulo complexo realizado com uma mistura morna preparada com zeólitas $\left(135^{\circ} \mathrm{C}\right)$, em comparação com uma mistura de referência $\left(155^{\circ} \mathrm{C}\right)$, ambas 
com CAP 50-70. De modo geral, a mistura morna mostrou um comportamento à fadiga inferior ao da mistura convencional, embora seus parâmetros de módulo complexo tenham sido relativamente superiores em temperaturas abaixo de $30^{\circ} \mathrm{C}$.

Já Fritzen et al. (2009), da Coordenação dos Programas de Pós-Graduação de Engenharia da Universidade Federal do Rio de Janeiro (COPPE-UFRJ), apresentaram uma pesquisa que envolvia dois trechos experimentais com mistura morna, um sem aditivo (compactação a $115^{\circ} \mathrm{C}$ ) e outro com aditivo A-SAT da Petrobras (compactação a $106^{\circ} \mathrm{C}$ ), comparativamente com uma mistura a quente (compactação a $145^{\circ} \mathrm{C}$ ), cujas obras ocorreram na Cidade Universitária do Rio de Janeiro e foram finalizadas no final de 2008. Nesta ocasião, foi empregado um simulador de tráfego tipo Heavy Vehicle Simulator (HVS) e, embora o segmento de mistura morna com aditivo tenha sido executado em um local que levou os pesquisadores a finalizarem o teste antes do esperado (pois se descobriu posteriormente que a estrutura subjacente continha uma placa rígida antiga deteriorada), o resultado deste trecho naquele momento foi considerado satisfatório, diferentemente do segmento de mistura morna sem aditivo, que mostrou comportamento inferior ao da mistura de referência.

Além disso, este grupo de pesquisas da COPPE-UFRJ também iniciou em 2010 um outro estudo que contemplará a execução de um trecho experimental de mistura morna, desta vez na BR-040 (sob concessão da Concer). Nesta pesquisa será avaliado o desempenho de um trecho dimensionado pelo método mecanísticoempírico SisPav, em comparação com uma mistura convencional, cujas dosagens serão realizadas pelo método SUPERPAVE. Em laboratório, serão conduzidos ensaios para a verificação de propriedades mecânicas, como fadiga por carga repetida e deformação permanente em simulador de tráfego LPC. Adicionalmente, ainda será feita uma tentativa de definir curvas de desempenho. Cabe mencionar que este projeto faz parte da pesquisa relacionada ao novo método de dimensionamento de pavimentos que está em desenvolvimento, em uma parceria da Petrobras e da Rede Temática de Asfalto (MOTTA et al., 2010).

Cavalcanti (2010), que também estudou na COPPE-UFRJ, verificou em laboratório o comportamento mecânico de misturas mornas com Rediset $^{\mathrm{TM}} \mathrm{WMX}$ (compactadas a 110,120 e $130^{\circ} \mathrm{C}$ ), em comparação com uma mistura em temperatura convencional (compactada a $150^{\circ} \mathrm{C}$ ), todas preparadas com um ligante convencional de penetração 30-45. As dosagens foram realizadas pelos métodos 
Marshall e SUPERPAVE, sendo que no Marshall os teores de ligante encontrados para as misturas mornas (5,1 a 5,5\%) foram bastante próximos ao da mistura de referência (5,3\%) e na dosagem SUPERPAVE a oscilação aumentou ligeiramente, mas ainda não de maneira significativa (com teores de 4,6 a 4,7\% nas mornas e $4,9 \%$ na mistura convencional). No geral, os resultados de resistência à tração se mostraram muito similares entre as misturas estudadas, enquanto que os valores de módulo de resiliência já foram inferiores para as misturas mornas Marshall compactadas a 110 e $120^{\circ} \mathrm{C}$. 


\section{ESTUDO LABORATORIAL}

\subsection{MATERIAIS}

Nesta etapa da pesquisa foram realizados ensaios com três tipos de misturas asfálticas mornas preparadas com aditivo surfactante, denominadas WMA1, WMA2 e WMA3, comparando-se os resultados obtidos com os de suas respectivas misturas a quente, chamadas aqui de HMA1, HMA2 e $\mathrm{HMA}^{10}$. Cabe mencionar que as únicas variáveis entre uma mistura morna e sua mistura de referência são o uso do aditivo surfactante e a redução das temperaturas de usinagem e compactação.

Os três tipos de misturas asfálticas diferem-se entre si no que se refere ao ligante e à origem/granulometria dos agregados; com as misturas 1 e 2 foram utilizados asfaltos convencionais CAP 50-70 e CAP 30-45, respectivamente, além de graduação contínua. Já as misturas 3 foram elaboradas com asfalto-borracha e granulometria semidescontínua. Os concretos asfálticos 1 e 2 têm características de materiais usualmente empregados na pavimentação brasileira, enquanto as misturas 3 (quente e morna) envolvem materiais com características diferentes, mas cujo uso vem sendo difundido no setor. $\mathrm{O}$ asfalto-borracha tem tido forte apelo ambiental por empregar um grande volume de pneus inservíveis, onde a borracha ainda confere melhorias para as misturas asfálticas, como aumento da flexibilidade, por exemplo. Já a graduação gap-graded também vem sendo introduzida no Brasil, para garantir melhor textura superficial do pavimento e, por consequência, maior segurança ao motorista, apresentando características de macrotextura aberta ou rugosa e volume de vazios não elevado (BERNUCCl et al., 2008).

Conforme mencionado no capítulo 1, houve mudança do aditivo após alguns ensaios com a primeira mistura morna avaliada, mas para um produto também surfactante líquido. A Tabela 4 apresenta as misturas asfálticas estudadas.

\footnotetext{
${ }^{10}$ A nomenclatura utilizada nesta pesquisa se baseia naquela usualmente empregada no âmbito internacional para misturas mornas (WMA - Warm Mix Asphalt) e para misturas a quente (HMA - Hot Mix Asphalt).
} 
Tabela 4 - Misturas asfálticas estudadas

\begin{tabular}{|c|c|c|c|c|c|}
\hline $\begin{array}{l}\text { Mistura } \\
\text { asfáltica }\end{array}$ & $\begin{array}{l}\text { Aditivo para } \\
\text { mistura morna }\end{array}$ & $\begin{array}{l}\text { Ligante } \\
\text { asfáltico }\end{array}$ & $\begin{array}{l}\text { Origem dos } \\
\text { agregados } \\
\text { (Pedreira) }\end{array}$ & $\begin{array}{l}\text { Distribuição } \\
\text { granulométrica }\end{array}$ & $\begin{array}{c}\mathrm{TMN}^{*} \text { dos } \\
\text { agregados } \\
\text { [mm] }\end{array}$ \\
\hline WMA1 & Cecabase $\mathrm{RT}^{\circledR}$ & \multirow{2}{*}{ CAP 50-70 } & \multirow{2}{*}{ Sta. Isabel } & \multirow{2}{*}{$\begin{array}{c}\text { Contínua } \\
\text { faixa C DNIT }\end{array}$} & \multirow{2}{*}{$\begin{array}{c}12,5 \\
(1 / 2 ")\end{array}$} \\
\hline HMA1 & --- & & & & \\
\hline WMA2 & Gemul XT14 & \multirow{2}{*}{ CAP $30-45$} & \multirow{2}{*}{$\begin{array}{l}\text { Serveng } \\
\text { Barueri }\end{array}$} & \multirow{2}{*}{$\begin{array}{c}\text { Contínua } \\
\text { faixa C DNIT }\end{array}$} & \multirow{2}{*}{$\begin{array}{l}12,5 \\
(1 / 2 ")\end{array}$} \\
\hline HMA2 & --- & & & & \\
\hline WMA3 & Gemul XT14 & \multirow{2}{*}{$\begin{array}{l}\text { asfalto- } \\
\text { borracha }\end{array}$} & \multirow{2}{*}{ Basalto 6} & \multirow{2}{*}{$\begin{array}{l}\text { Semidescontínua faixa } \\
\text { Caltrans gap-graded }\end{array}$} & \multirow{2}{*}{$\begin{array}{l}9,5 \\
(3 / 8 ")\end{array}$} \\
\hline HMA3 & --- & & & & \\
\hline
\end{tabular}

* TMN = tamanho máximo nominal

\subsubsection{Agregados}

\subsubsection{WMA1 e HMA1 (Pedreira Santa Isabel)}

Os agregados utilizados para as misturas asfálticas denominadas WMA1 e HMA1 eram procedentes da Pedreira Santa Isabel, localizada na cidade de mesmo nome, na Grande São Paulo. Os materiais pétreos, de origem granito/gnaisse, estavam separados em quatro frações, a saber: brita $1 / 2$, pedrisco, areia artificial e pó-de-pedra. Além disso, também foi fornecida cal hidratada do tipo $\mathrm{CH}-\mathrm{I}$.

Os ensaios de caracterização dos agregados foram realizados no laboratório do CPR/CCR, cujos resultados, especificações utilizadas e limites exigidos são apresentados na Tabela 5. 
Tabela 5 - Caracterização dos agregados - Pedreira Santa Isabel

\begin{tabular}{|c|c|c|c|c|}
\hline Parâmetro & Norma & Material & Resultado & $\begin{array}{c}\text { Limites } \\
\text { (especificação) }\end{array}$ \\
\hline \multirow{6}{*}{$\begin{array}{c}\text { Massa } \\
\text { específica } \\
\text { real } \\
{\left[\mathrm{g} / \mathrm{cm}^{3}\right]}\end{array}$} & \multirow{6}{*}{$\begin{array}{l}\text { AASHTO } \\
\text { T84/T85 }\end{array}$} & brita $1 / 2$ & 2,803 & \multirow{6}{*}{ - } \\
\hline & & pedrisco & 2,804 & \\
\hline & & areia artificial & 2,834 & \\
\hline & & pó-de-pedra & 2,804 & \\
\hline & & cal CH-I & 2,450 & \\
\hline & & mistura & 2,808 & \\
\hline \multirow{6}{*}{$\begin{array}{c}\text { Massa } \\
\text { específica } \\
\text { aparente } \\
{\left[\mathrm{g} / \mathrm{cm}^{3}\right]}\end{array}$} & \multirow{6}{*}{$\begin{array}{l}\text { AASHTO } \\
\text { T84/T85 }\end{array}$} & brita 1/2 & 2,752 & \multirow{6}{*}{ - } \\
\hline & & pedrisco & 2,724 & \\
\hline & & areia artificial & 2,820 & \\
\hline & & pó-de-pedra & 2,724 & \\
\hline & & $\mathrm{cal} \mathrm{CH-I}$ & 2,450 & \\
\hline & & mistura & 2,758 & \\
\hline \multirow{6}{*}{$\begin{array}{c}\text { Massa } \\
\text { específica } \\
\text { efetiva } \\
{\left[\mathrm{g} / \mathrm{cm}^{3}\right]}\end{array}$} & \multirow{6}{*}{$\begin{array}{l}\text { AASHTO } \\
\text { T209 }\end{array}$} & brita $1 / 2$ & 2,783 & \\
\hline & & pedrisco & 2,772 & \\
\hline & & areia artificial & 2,829 & \\
\hline & & pó-de-pedra & 2,772 & \\
\hline & & cal CH-I & 2,450 & \\
\hline & & mistura & 2,788 & \\
\hline \multirow{2}{*}{$\begin{array}{l}\text { Índice } \\
\text { de forma }\end{array}$} & \multirow{2}{*}{ NBR 7809} & brita $1 / 2$ & 2,7 & \multirow{2}{*}{$\begin{array}{c}<3 \\
(\text { NBR 7211) }\end{array}$} \\
\hline & & pedrisco & 2,7 & \\
\hline \multirow{2}{*}{$\begin{array}{c}\text { Lamelares } \\
{[\%]}\end{array}$} & \multirow{2}{*}{ NBR 7809} & brita $1 / 2$ & 2,0 & \multirow{2}{*}{$\begin{array}{l}<10 \% \text { em } 1: 5 \\
\text { (SUPERPAVE) }\end{array}$} \\
\hline & & pedrisco & 1,0 & \\
\hline
\end{tabular}

O CPR/CCR ainda realizou a análise granulométrica dos agregados, por meio de peneiramento, empregando as especificações AASHTO T27-06 e AASHTO T1105. A Tabela 6 indica a distribuição granulométrica dos agregados e a composição da mistura final.

Tabela 6 - Distribuição granulométrica dos agregados e da mistura final para as misturas asfálticas HMA1 e WMA1- Pedreira Santa Isabel

\begin{tabular}{ccccccc}
\hline Peneira & $\begin{array}{c}\text { Brita 1/2 } \\
{[\%]}\end{array}$ & $\begin{array}{c}\text { Pedrisco } \\
{[\%]}\end{array}$ & $\begin{array}{c}\text { Areia } \\
\text { artificial } \\
{[\%]}\end{array}$ & $\begin{array}{c}\text { Pó-de- } \\
\text { pedra } \\
{[\%]}\end{array}$ & $\begin{array}{c}\text { Cal } \\
\text { CH-I } \\
{[\%]}\end{array}$ & $\begin{array}{c}\text { Mistura } \\
{[\%]}\end{array}$ \\
\hline $1 "(25,4 \mathrm{~mm})$ & 100,0 & 100,0 & 100,0 & 100,0 & 100,0 & 100,0 \\
\hline $3 / 4 "(19,1 \mathrm{~mm})$ & 100,0 & 100,0 & 100,0 & 100,0 & 100,0 & 100,0 \\
\hline $1 / 2^{\prime \prime}(12,7 \mathrm{~mm})$ & 83,5 & 100,0 & 100,0 & 100,0 & 100,0 & 95,9 \\
\hline $3 / 8 "(9,52 \mathrm{~mm})$ & 22,6 & 97,9 & 100,0 & 100,0 & 100,0 & 80,0 \\
\hline $4(4,75 \mathrm{~mm})$ & 1,8 & 18,9 & 97,2 & 92,2 & 100,0 & 49,4 \\
\hline $10(2,0 \mathrm{~mm})$ & 1,1 & 4,1 & 68,1 & 17,2 & 100,0 & 27,5 \\
\hline $40(0,42 \mathrm{~mm})$ & 1,0 & 3,0 & 45,5 & 5,8 & 98,0 & 18,4 \\
\hline $80(0,18 \mathrm{~mm})$ & 0,9 & 2,5 & 32,5 & 4,6 & 98,0 & 13,8 \\
\hline $200(0,08 \mathrm{~mm})$ & 0,7 & 1,6 & 17,4 & 3,0 & 98,0 & 8,1 \\
\hline
\end{tabular}


Para a composição da curva granulométrica foram empregados $25 \%$ de brita $1 / 2,30 \%$ de pedrisco, 33,5\% de pó-de-pedra, $10 \%$ de areia artificial e 1,5\% de cal $\mathrm{CH}-\mathrm{I}$ (mistura seca). A curva obtida se enquadra na Faixa C do DNIT (DNIT ES031/06), caracterizando-se por uma distribuição contínua bem-graduada com tamanho máximo nominal dos agregados de 12,5 mm (Figura 24).

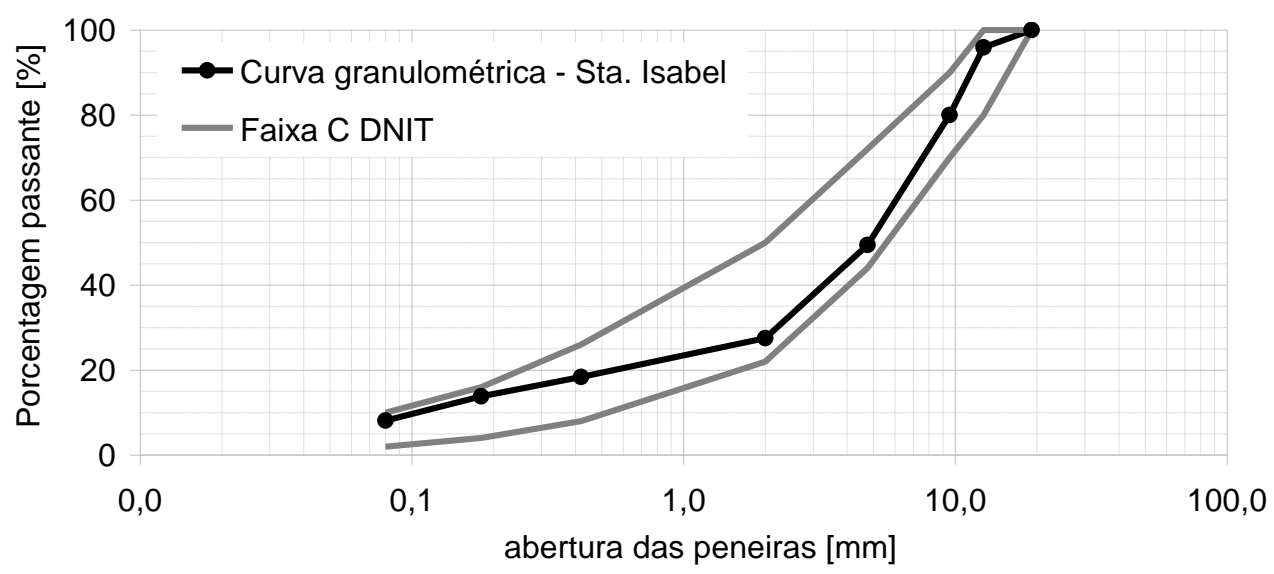

Figura 24 - Curva granulométrica - Agregados Pedreira Santa Isabel

\subsubsection{WMA2 e HMA2 (Pedreira Serveng Barueri)}

Os agregados utilizados para as misturas asfálticas denominadas WMA2 e HMA2 eram procedentes da Pedreira Serveng Barueri, localizada na cidade de Barueri, na Grande São Paulo. Os materiais pétreos, de origem granito/gnaisse, estavam separados em três frações, a saber: brita 1, pedrisco e pó-de-pedra. Além disso, também foi fornecida cal hidratada do tipo $\mathrm{CH}-\mathrm{I}$.

Os ensaios de caracterização dos agregados foram realizados no laboratório do CPR/CCR, cujos resultados e especificações utilizadas são apresentados na Tabela 7. 
Tabela 7 - Caracterização dos agregados - Pedreira Serveng Barueri

\begin{tabular}{|c|c|c|c|}
\hline Parâmetro & Norma & Material & Resultado \\
\hline \multirow{5}{*}{$\begin{array}{c}\text { Massa } \\
\text { específica } \\
\text { real } \\
{\left[\mathrm{g} / \mathrm{cm}^{3}\right]}\end{array}$} & \multirow{5}{*}{$\begin{array}{c}\text { AASHTO } \\
\text { T84/T85 }\end{array}$} & brita 1 & 2,705 \\
\hline & & pedrisco & 2,722 \\
\hline & & pó-de-pedra & 2,720 \\
\hline & & cal CH-I & 2,450 \\
\hline & & mistura & 2,714 \\
\hline \multirow{5}{*}{$\begin{array}{c}\text { Massa } \\
\text { específica } \\
\text { aparente } \\
{\left[\mathrm{g} / \mathrm{cm}^{3}\right]}\end{array}$} & \multirow{5}{*}{$\begin{array}{c}\text { AASHTO } \\
\text { T84/T85 }\end{array}$} & brita 1 & 2,676 \\
\hline & & pedrisco & 2,674 \\
\hline & & pó-de-pedra & 2,665 \\
\hline & & cal $\mathrm{CH}-\mathrm{I}$ & 2,450 \\
\hline & & mistura & 2,667 \\
\hline \multirow{5}{*}{$\begin{array}{c}\text { Massa } \\
\text { específica } \\
\text { efetiva } \\
{\left[\mathrm{g} / \mathrm{cm}^{3}\right]}\end{array}$} & \multirow{5}{*}{$\begin{array}{c}\text { AASHTO } \\
\text { T209 }\end{array}$} & brita 1 & 2,687 \\
\hline & & pedrisco & 2,692 \\
\hline & & pó-de-pedra & 2,685 \\
\hline & & cal CH-I & 2,450 \\
\hline & & mistura & 2,685 \\
\hline
\end{tabular}

O CPR/CCR ainda realizou a análise granulométrica dos agregados, por meio de peneiramento, empregando as especificações AASHTO T27-06 e AASHTO T1105. A Tabela 8 indica a distribuição granulométrica dos agregados e a composição da mistura final.

Tabela 8 - Distribuição granulométrica dos agregados e da mistura final para as misturas asfálticas HMA2 e WMA2- Pedreira Serveng Barueri

\begin{tabular}{cccccc}
\hline Peneira & $\begin{array}{c}\text { Brita 1 } \\
{[\%]}\end{array}$ & $\begin{array}{c}\text { Pedrisco } \\
{[\%]}\end{array}$ & $\begin{array}{c}\text { Pó-de-pedra } \\
{[\%]}\end{array}$ & $\begin{array}{c}\text { Cal CH-I } \\
{[\%]}\end{array}$ & $\begin{array}{c}\text { Mistura } \\
{[\%]}\end{array}$ \\
\hline $1 "(25,4 \mathrm{~mm})$ & 100,0 & 100,0 & 100,0 & 100,0 & 100,0 \\
\hline $3 / 4 "(19,1 \mathrm{~mm})$ & 100,0 & 100,0 & 100,0 & 100,0 & 100,0 \\
\hline $1 / 2 "(12,7 \mathrm{~mm})$ & 49,6 & 100,0 & 100,0 & 100,0 & 92,9 \\
\hline $3 / 8 "(9,52 \mathrm{~mm})$ & 16,0 & 98,9 & 100,0 & 100,0 & 87,7 \\
\hline $4(4,75 \mathrm{~mm})$ & 2,5 & 14,1 & 98,4 & 100,0 & 47,1 \\
\hline $10(2,0 \mathrm{~mm})$ & 2,0 & 3,5 & 70,0 & 100,0 & 31,0 \\
\hline $40(0,42 \mathrm{~mm})$ & 1,8 & 1,9 & 33,7 & 98,0 & 15,9 \\
\hline $80(0,18 \mathrm{~mm})$ & 1,6 & 1,5 & 20,4 & 98,0 & 10,4 \\
\hline $200(0,08 \mathrm{~mm})$ & 1,3 & 1,1 & 11,3 & 98,0 & 6,5 \\
\hline
\end{tabular}

Para a composição da curva granulométrica foram empregados $14 \%$ de brita 1, 45\% de pedrisco, 39,5\% de pó-de-pedra e 1,5\% de cal $\mathrm{CH}-\mathrm{I}$ (mistura seca). A curva obtida se enquadra na Faixa C do DNIT (DNIT ES031/06), apresenta distribuição contínua e possui tamanho máximo nominal dos agregados de $12,5 \mathrm{~mm}$ (Figura 25). 


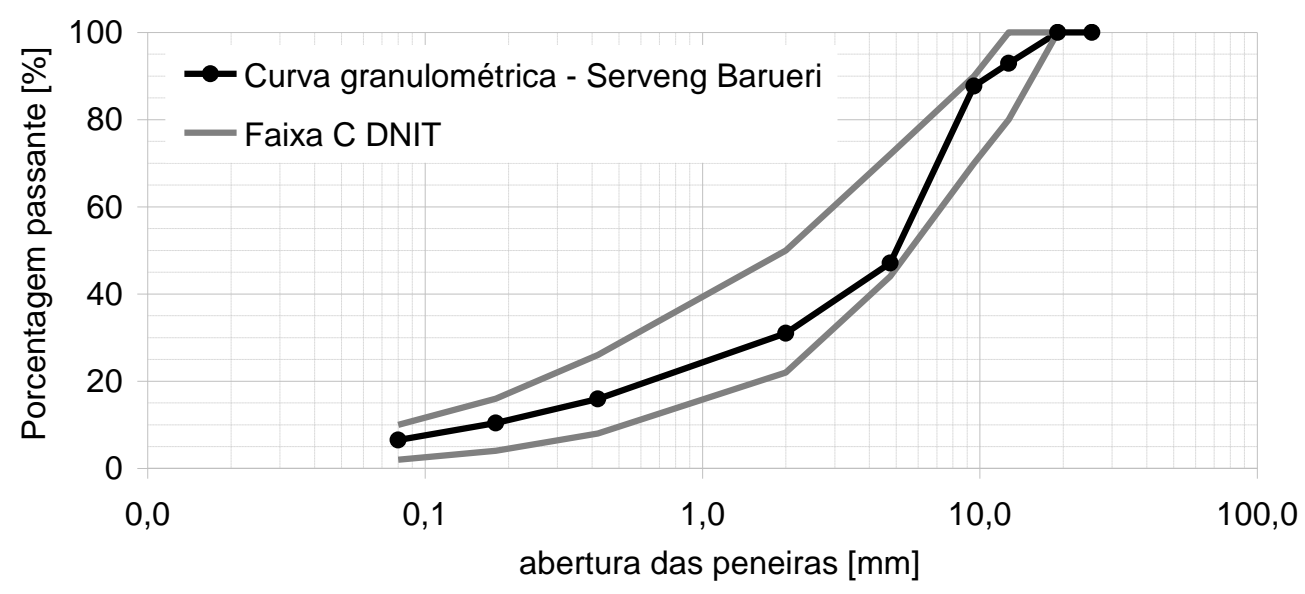

Figura 25 - Curva granulométrica - Agregados Pedreira Serveng Barueri

\subsubsection{WMA3 e HMA3 (Pedreira Basalto 6)}

Os agregados utilizados para as misturas asfálticas denominadas WMA3 e HMA3 eram procedentes da Pedreira Basalto 6, localizada na cidade de Campinas, no interior de São Paulo. Os materiais pétreos, de origem granito/gnaisse, estavam separados em duas frações, a saber: pedrisco e pó-de-pedra. Além disso, também foi fornecida cal hidratada do tipo $\mathrm{CH}-\mathrm{I}$.

Os ensaios de caracterização dos agregados foram realizados no laboratório da Basalto, pertencente ao Grupo Estrutural, cujos resultados e especificações utilizadas são apresentados na Tabela 9.

Tabela 9 - Caracterização dos agregados - Pedreira Basalto 6

\begin{tabular}{|c|c|c|c|}
\hline Parâmetro & Norma & Material & Resultado \\
\hline \multirow{4}{*}{$\begin{array}{c}\text { Massa } \\
\text { específica } \\
\text { real } \\
{\left[\mathrm{g} / \mathrm{cm}^{3}\right]}\end{array}$} & \multirow{4}{*}{$\begin{array}{c}\text { AASHTO } \\
\text { T84/T85 }\end{array}$} & pedrisco & 2,726 \\
\hline & & pó-de-pedra & 2,734 \\
\hline & & cal CH-I & 2,468 \\
\hline & & mistura & 2,724 \\
\hline \multirow{4}{*}{$\begin{array}{c}\text { Massa } \\
\text { específica } \\
\text { aparente } \\
{\left[\mathrm{g} / \mathrm{cm}^{3}\right]}\end{array}$} & \multirow{4}{*}{$\begin{array}{c}\text { AASHTO } \\
\text { T84/T85 }\end{array}$} & pedrisco & 2,677 \\
\hline & & pó-de-pedra & 2,665 \\
\hline & & cal CH-I & 2,468 \\
\hline & & mistura & 2,670 \\
\hline
\end{tabular}

A Basalto/Estrutural ainda realizou a análise granulométrica dos agregados, por meio de peneiramento, empregando as especificações AASHTO T27-06 e 
AASHTO T11-05. A Tabela 10 indica a distribuição granulométrica dos agregados e a composição da mistura final.

Tabela 10 - Distribuição granulométrica dos agregados e da mistura final para as misturas asfálticas HMA3 e WMA3 - Pedreira Basalto 6

\begin{tabular}{ccccc}
\hline Peneira & $\begin{array}{c}\text { Pedrisco } \\
{[\%]}\end{array}$ & $\begin{array}{c}\text { Pó-de-pedra } \\
{[\%]}\end{array}$ & $\begin{array}{c}\text { Cal CH-I } \\
{[\%]}\end{array}$ & $\begin{array}{c}\text { Mistura } \\
{[\%]}\end{array}$ \\
\hline $1 / 2 "(12,7 \mathrm{~mm})$ & 100,0 & 100,0 & 100,0 & 100,0 \\
\hline $3 / 8 "(9,52 \mathrm{~mm})$ & 95,3 & 100,0 & 100,0 & 96,9 \\
\hline $4(4,75 \mathrm{~mm})$ & 6,5 & 96,1 & 100,0 & 37,0 \\
\hline $8(2,4 \mathrm{~mm})$ & 0,6 & 67,7 & 100,0 & 23,9 \\
\hline $16(1,2 \mathrm{~mm})$ & 0,6 & 50,8 & 100,0 & 18,4 \\
\hline $30(0,60 \mathrm{~mm})$ & 0,6 & 32,2 & 100,0 & 12,4 \\
\hline $50(0,30 \mathrm{~mm})$ & 0,6 & 25,2 & 100,0 & 10,1 \\
\hline $100(0,15 \mathrm{~mm})$ & 0,5 & 17,7 & 98,0 & 7,6 \\
\hline $200(0,08 \mathrm{~mm})$ & 0,5 & 10,8 & 94,5 & 5,3 \\
\hline
\end{tabular}

Para a composição da curva granulométrica foram empregados $66,0 \%$ de pedrisco, 32,5\% de pó-de-pedra e 1,5\% de cal $\mathrm{CH}-\mathrm{I}$ (mistura seca). A curva obtida se enquadra na faixa gap-graded do Caltrans (Departamento de Transportes do Estado da Califórnia dos Estados Unidos), apresenta distribuição semidescontínua e possui tamanho máximo nominal dos agregados de 9,5 mm (Figura 26).

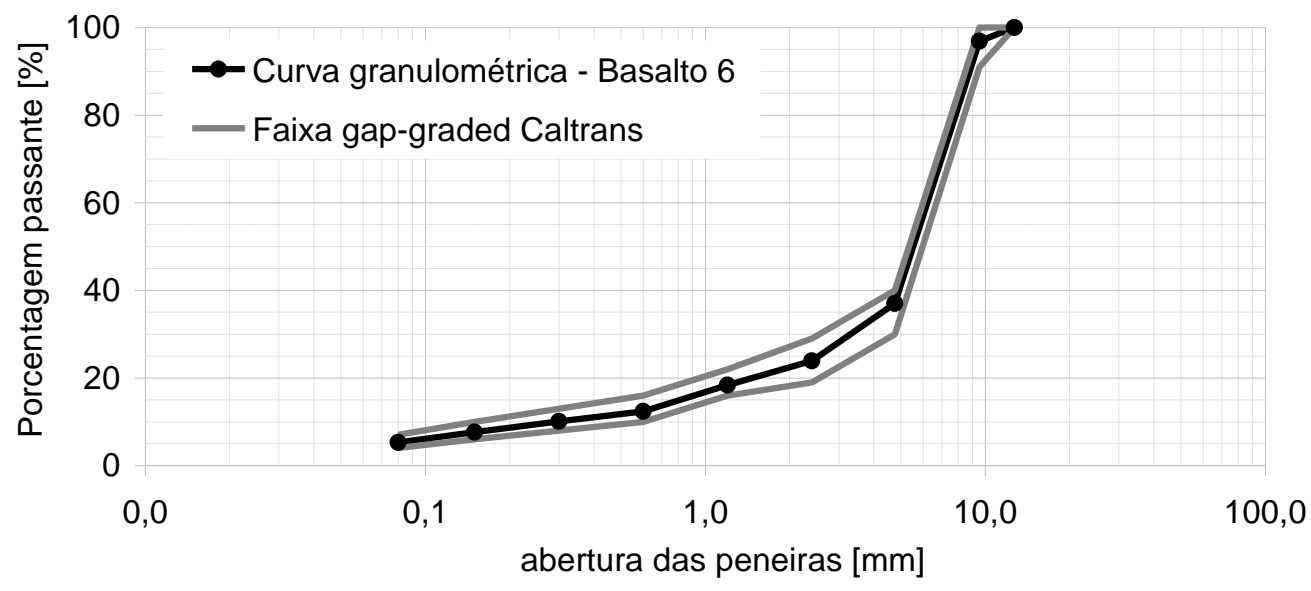

Figura 26 - Curva granulométrica - Agregados Pedreira Basalto 6 


\subsubsection{Comparativo: Curvas granulométricas}

Para melhor visualização, a Figura 27 apresenta as três curvas granulométricas deste estudo, reunidas em um único gráfico.

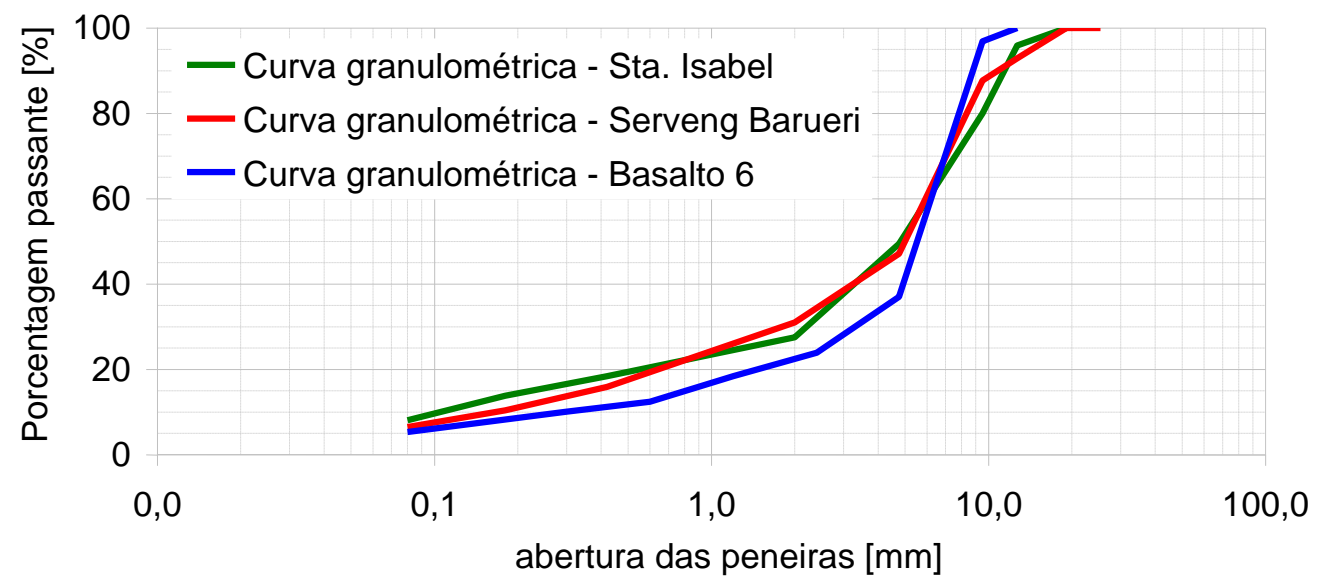

Figura 27 - Curvas granulométricas utilizadas na presente pesquisa

\subsubsection{Ligante asfáltico}

\subsubsection{WMA1 e HMA1 (CAP 50-70)}

O ligante utilizado para as misturas asfálticas denominadas WMA1 e HMA1 se tratava de um asfalto convencional, classificado por penetração como CAP 50-70, procedente da refinaria REVAP/Petrobras (São José dos Campos - SP).

Os ensaios de caracterização deste ligante foram realizados no laboratório do CPR/CCR, cujos resultados, especificações utilizadas e limites exigidos são apresentados na Tabela 11. 
Tabela 11 - Caracterização do ligante asfáltico CAP 50-70 para as misturas asfálticas HMA1 e WMA1

\begin{tabular}{cccc}
\hline Parâmetro & Norma & Resultado & $\begin{array}{c}\text { Limites } \\
\text { ANP }(2005)\end{array}$ \\
\hline $\begin{array}{c}\text { Penetração } \\
{[0,1 \mathrm{~mm}]}\end{array}$ & NBR 6576 & 52 & $50-70$ \\
\hline $\begin{array}{c}\text { Ponto de amolecimento } \\
{\left[{ }^{\circ} \mathrm{C}\right]}\end{array}$ & NBR 6560 & 51 & mínimo 46 \\
\hline $\begin{array}{c}\text { Viscosidade Saybolt-Furol* } \\
{[\mathrm{sSF}]}\end{array}$ & NBR 14950 & $\begin{array}{c}185\left(135^{\circ} \mathrm{C}\right) \\
-88\left(150^{\circ} \mathrm{C}\right)\end{array}$ & mínimo 141 \\
\hline $\begin{array}{c}\text { Densidade } \\
\text { relativa }\end{array}$ & AASHTO T228 & $\left.1,0177^{\circ} \mathrm{C}\right)$ & 30 a 150 \\
\hline
\end{tabular}

* $1 \mathrm{sSF}$ (segundo Saybolt-Furol) $=2 \mathrm{cP}$ (centipoise)

\subsubsection{WMA2 e HMA2 (CAP 30-45)}

O ligante utilizado para as misturas asfálticas denominadas WMA2 e HMA2 também se tratava de um asfalto convencional, mas classificado por penetração como CAP 30-45 (maior consistência), procedente da refinaria REPLAN/Petrobras (Paulínia-SP).

Os ensaios de caracterização deste ligante foram realizados no laboratório do CPR/CCR, cujos resultados, especificações utilizadas e limites exigidos são apresentados na Tabela 12.

Tabela 12 - Caracterização do ligante asfáltico CAP 30-45 para as misturas asfálticas HMA2 e WMA2

\begin{tabular}{cccc}
\hline Parâmetro & Norma & Resultado & $\begin{array}{c}\text { Limites } \\
\text { ANP }(2005)\end{array}$ \\
\hline $\begin{array}{c}\text { Penetração } \\
{[0,1 \mathrm{~mm}]}\end{array}$ & NBR 6576 & 30 & $30-45$ \\
\hline $\begin{array}{c}\text { Ponto de amolecimento } \\
{\left[{ }^{\circ} \mathrm{C}\right]}\end{array}$ & NBR 6560 & 54 & mínimo 52 \\
\hline $\begin{array}{c}\text { Viscosidade Brookfield } \\
{[\mathrm{CP}]}\end{array}$ & ASTM D4402 & $\begin{array}{c}483\left(135^{\circ} \mathrm{C}\right) \\
-\frac{255\left(150^{\circ} \mathrm{C}\right)}{}\end{array}$ & $\begin{array}{c}\text { mínimo } 141 \\
\text { mínimo } 50\end{array}$ \\
\hline $\begin{array}{c}\text { Densidade } \\
\text { relativa }\end{array}$ & AASHTO T228 & 1,050 & - \\
\hline
\end{tabular}

\subsubsection{WMA3 e HMA3 (asfalto-borracha)}

O ligante utilizado para as misturas asfálticas denominadas WMA3 e HMA3 se tratava de um asfalto modificado por borracha de pneu moído, tipo terminal blending, comercialmente denominado Ecoflex A (tipo AB22, com 20\% de borracha), 
fornecido pela Greca Asfaltos (Guarulhos - Grande São Paulo). A empresa realizou os ensaios de caracterização deste ligante, cujos resultados, especificações utilizadas e limites exigidos estão indicados na Tabela 13.

Tabela 13 - Caracterização do asfalto-borracha para as misturas asfálticas HMA3 e WMA3

\begin{tabular}{cccc}
\hline Parâmetro & Norma & Resultado & $\begin{array}{c}\text { Limites } \\
\text { ANP (2005) }\end{array}$ \\
\hline $\begin{array}{c}\text { Penetração } \\
{[0,1 \mathrm{~mm}]}\end{array}$ & NBR 6576 & 49 & $30-70$ \\
\hline $\begin{array}{c}\text { Ponto de amolecimento } \\
{\left[{ }^{\circ} \mathrm{C}\right]}\end{array}$ & NBR 6560 & 62 & mínimo 55 \\
\hline $\begin{array}{c}\text { Viscosidade Brookfield } \\
{[\mathrm{cP}]}\end{array}$ & NBR 15529 & $\begin{array}{c}2675 \\
\left(175^{\circ} \mathrm{C}\right)\end{array}$ & $2200-4000$ \\
\hline $\begin{array}{c}\text { Recuperação elástica } \\
{[\%]}\end{array}$ & NLT 329/91 & 78 & mínimo 55 \\
\hline $\begin{array}{c}\text { Densidade } \\
\text { relativa }\end{array}$ & NBR 6296 & 1,031 & - \\
\hline
\end{tabular}

\subsubsection{Comparativo: Consistência dos ligantes asfálticos}

Para melhor visualização, a Figura 28 apresenta as principais características de consistência dos ligantes asfálticos deste estudo, reunidas em um único gráfico.

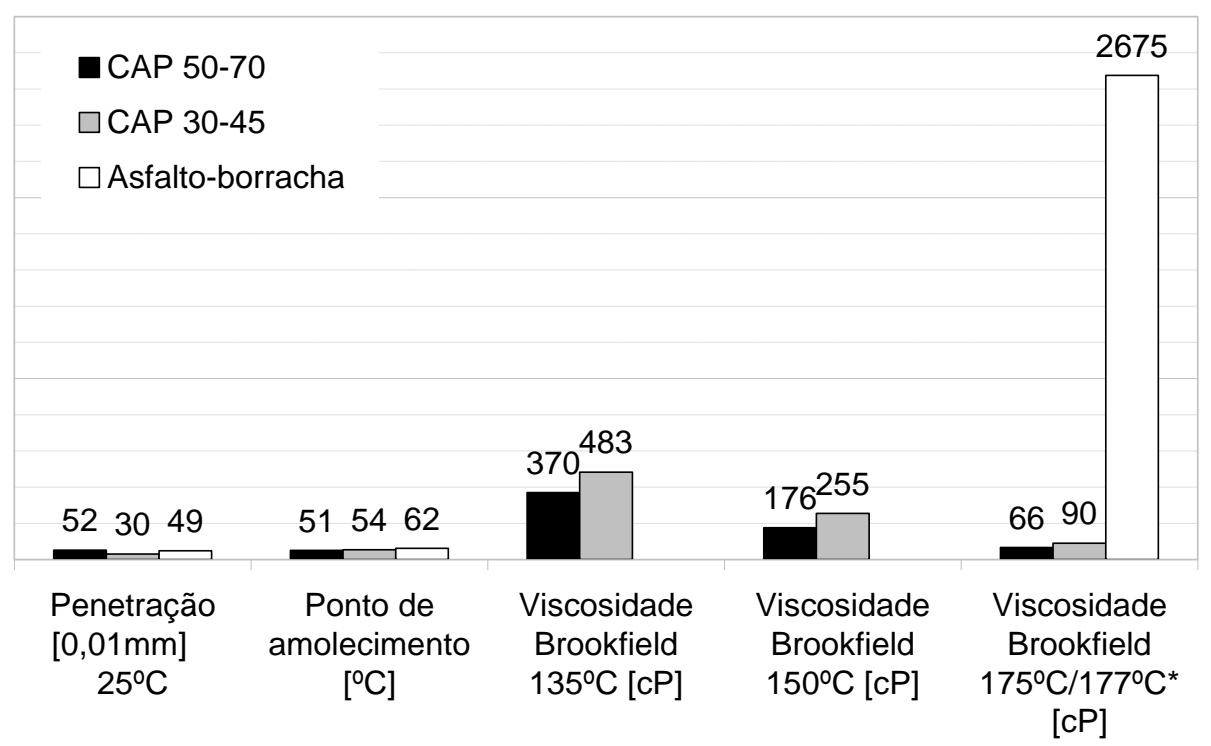

* O asfalto-borracha é ensaiado a $175^{\circ} \mathrm{C}$, enquanto o CAP 50-70 e o CAP $30-45$ o são a $177^{\circ} \mathrm{C}$ Obs: Os valores de viscosidade do CAP 50-70 foram obtidos em viscosímetro Saybolt-Furol [sSF] e convertidos para unidade compatível com viscosímetro Brookfield, ou centipoise [cP] (1 sSF = $2 \mathrm{cP}$ )

Figura 28 - Características de consistência dos ligantes asfálticos da presente pesquisa 


\subsubsection{Aditivo para mistura morna e consistência do ligante asfáltico com o produto}

Esta pesquisa foi iniciada com o aditivo Cecabase $\mathrm{RT}^{\circledR}$, sendo este depois substituído por outro surfactante, o Gemul XT14, conforme explicado anteriormente. O Cecabase $\mathrm{RT}^{\circledR}$ foi usado com a WMA1, enquanto o Gemul XT14 foi utilizado para preparar a WMA2 e a WMA3. A WMA1 e a WMA2 receberam 0,3\% de aditivo em laboratório, ao passo que a WMA3 recebeu $0,4 \%$ de produto, ainda no fornecedor de asfalto.

A incorporação do aditivo em laboratório era realizada pouco antes do processo de usinagem, após a etapa de aquecimento do ligante. Resumidamente, depois do asfalto ser aquecido à temperatura requerida para a usinagem, o aditivo introduzido e misturado por um período de $15 \mathrm{~min}$, sob um banho térmico para manutenção da temperatura, cuja agitação era realizada por uma hélice acoplada a um equipamento automático (Figura 29).

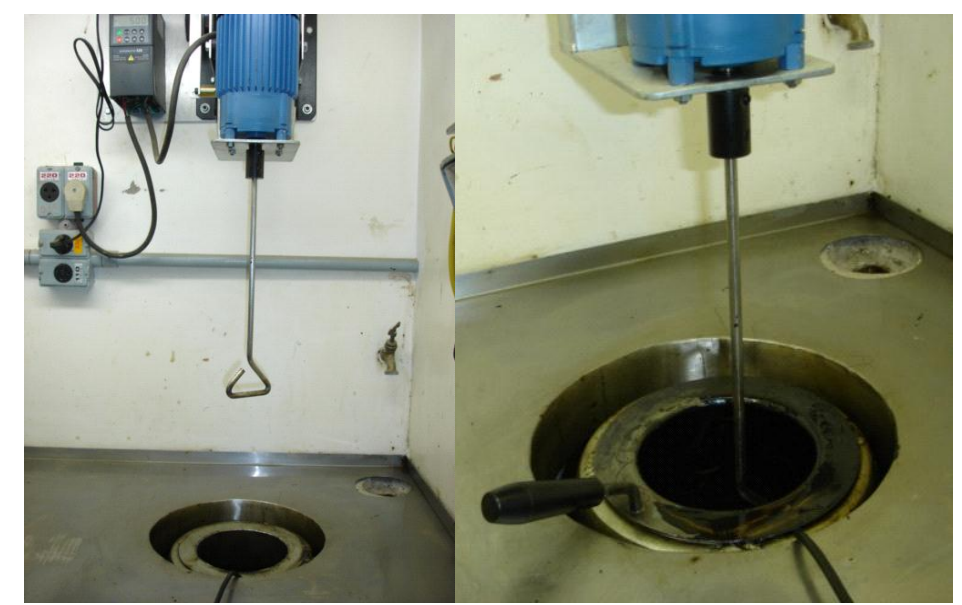

Figura 29 - Mistura de aditivo ao ligante asfáltico - Detalhe do equipamento do LTP/EPUSP

Como relatado no item 2.2.3.1, a literatura menciona que os aditivos surfactantes não alteram propriedades de consistência dos asfaltos, como penetração, ponto de amolecimento e viscosidade. Nesta pesquisa, procurou-se também confirmar tal característica destes produtos, a partir da realização de alguns destes ensaios com o CAP 50-70 e com o CAP 30-45 misturados aos surfactantes, comparando os resultados com aqueles dos asfaltos puros (indicados na Tabela 11 e na Tabela 12). Os valores são apresentados na Tabela 14 e, de fato, pode-se dizer 
que não houve variação de consistência dos ligantes com a incorporação dos aditivos.

Tabela 14 - Consistência dos CAPs 50-70 e 30-45 com e sem surfactante

\begin{tabular}{|c|c|c|c|c|c|}
\hline \multicolumn{2}{|c|}{ Ensaio } & $\begin{array}{c}\text { CAP 50-70 } \\
+ \\
\text { Cecabase RT }^{\circledR}\end{array}$ & CAP 50-70 & $\begin{array}{c}\text { CAP } 30-45 \\
+ \\
\text { Gemul XT14 }\end{array}$ & CAP $30-45$ \\
\hline \multicolumn{2}{|c|}{$\begin{array}{c}\text { Penetração } \\
{[0,1 \mathrm{~mm}]}\end{array}$} & NT & 52 & 33 & 30 \\
\hline \multicolumn{2}{|c|}{$\begin{array}{c}\text { Ponto de amolecimento } \\
{\left[{ }^{\circ} \mathrm{C}\right]}\end{array}$} & NT & 51 & 53 & 54 \\
\hline \multirow{3}{*}{$\begin{array}{l}\text { Viscosidade } \\
\text { [CP] }\end{array}$} & $135^{\circ} \mathrm{C}$ & $370^{*}$ & $370^{* *}$ & $495^{*}$ & $483^{*}$ \\
\hline & $150^{\circ} \mathrm{C}$ & $167^{*}$ & $176^{\star *}$ & $241^{*}$ & $255^{*}$ \\
\hline & $177^{\circ} \mathrm{C}$ & $49^{*}$ & $66^{\star \star}$ & $85^{*}$ & $90^{*}$ \\
\hline
\end{tabular}

NT = Não testado

* Viscosidade Brookfield

** Viscosidade Saybolt-Furol [sSF] convertida em centipoise [cP]

\subsection{TEMPERATURAS DE USINAGEM E COMPACTAÇÃO}

As temperaturas de usinagem e compactação das misturas a quente foram definidas da maneira usual, ou seja, a partir de ensaios realizados com os ligantes em viscosímetros, seguidos de plotagem de gráfico viscosidade $x$ temperatura (ASTM D2493-01). Os gráficos obtidos com o CAP 50-70 e com o CAP 30-45 são apresentados na Figura 30 e na Figura 31, respectivamente.

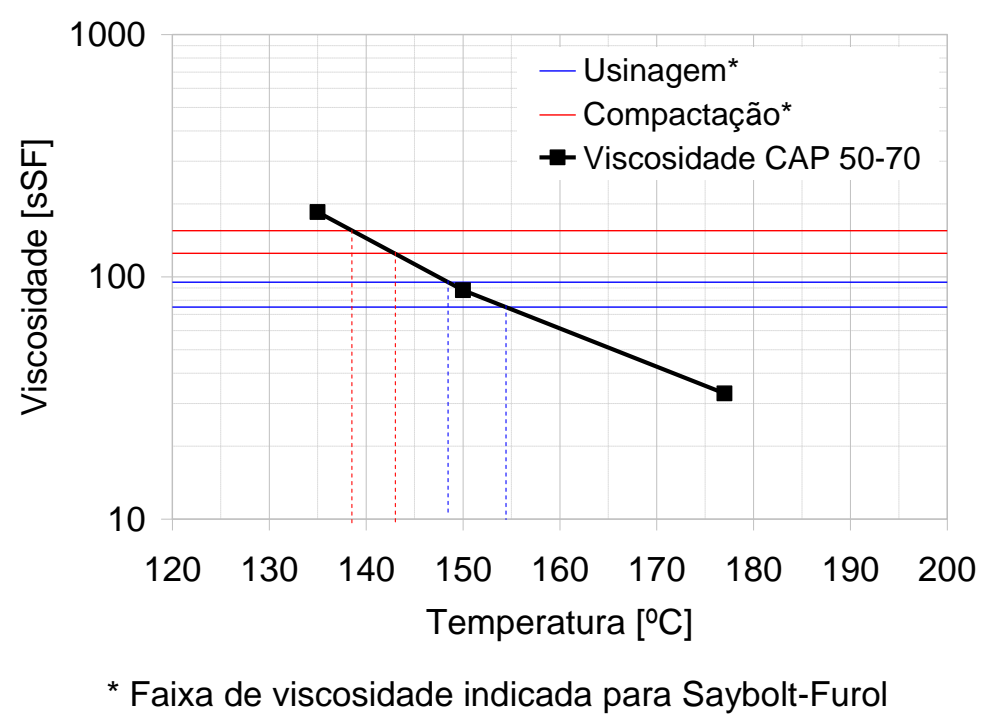

Figura 30 - Curva de viscosidade do CAP 50-70 (Saybolt-Furol) 


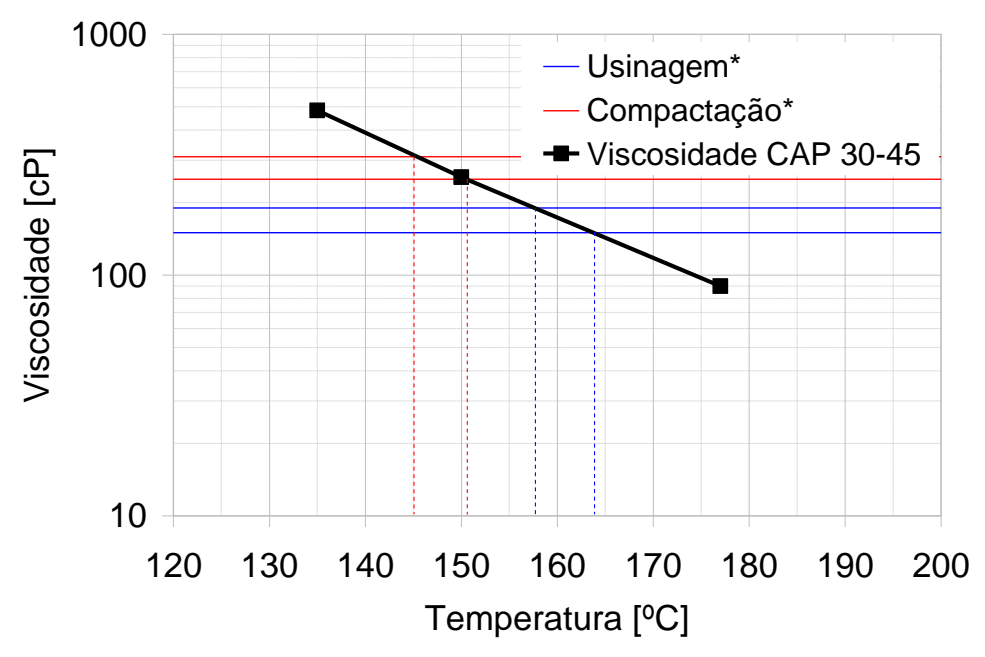

* Faixa de viscosidade indicada para viscosímetro rotacional

Figura 31 - Curva de viscosidade do CAP 30-45 (Brookfield)

No caso da HMA3 o ensaio com o asfalto-borracha foi feito no próprio fornecedor de asfalto, que então indicou as temperaturas de usinagem e compactação (apresentadas logo adiante na Tabela 15).

As temperaturas de trabalho das misturas mornas foram então estabelecidas, a partir das temperaturas de usinagem e compactação das misturas a quente. Como os asfaltos misturados aos aditivos para mistura morna desta pesquisa apresentaram características de consistência similares às do ligante puro (item anterior), no caso das misturas mornas optou-se por uma redução de temperatura de cerca de 25 a $35^{\circ} \mathrm{C}$ em relação à mistura convencional, por meio da diminuição da temperatura dos agregados, mantendo-se a temperatura do ligante asfáltico. A Tabela 15 indica as temperaturas de usinagem e de compactação definidas para cada mistura asfáltica estudada.

Tabela 15 - Temperaturas de usinagem e compactação

\begin{tabular}{|c|c|c|c|c|c|c|}
\hline $\begin{array}{l}\text { Mistura } \\
\text { asfáltica }\end{array}$ & $\begin{array}{l}\text { Temp. do } \\
\text { ligante } \\
{\left[{ }^{\circ} \mathrm{C}\right]}\end{array}$ & $\begin{array}{c}\text { Temp.dos } \\
\text { agregados } \\
{\left[{ }^{\circ} \mathrm{C}\right]}\end{array}$ & $\begin{array}{c}\text { Temp. } \\
\text { final de } \\
\text { usinagem } \\
{\left[{ }^{\circ} \mathrm{C}\right]}\end{array}$ & $\begin{array}{c}\text { Diferença } \\
\text { de temp. } \\
\text { usinagem } \\
{\left[{ }^{\circ} \mathrm{C}\right]}\end{array}$ & $\begin{array}{c}\text { Temp. } \\
\text { final de } \\
\text { compactação } \\
{\left[{ }^{\circ} \mathrm{C}\right]}\end{array}$ & $\begin{array}{c}\text { Diferença } \\
\text { de temp. } \\
\text { compactação } \\
{\left[{ }^{\circ} \mathrm{C}\right]}\end{array}$ \\
\hline HMA1 & 160 & 170 & 150 & \multirow{2}{*}{35} & 140 & \multirow{2}{*}{30} \\
\hline WMA1 & 160 & 115 & 115 & & 110 & \\
\hline HMA2 & 160 & 170 & 160 & \multirow{2}{*}{25} & 150 & \multirow{2}{*}{25} \\
\hline WMA2 & 160 & 135 & 135 & & 125 & \\
\hline HMA3 & 175 & 180 & 180 & \multirow{2}{*}{35} & 175 & \multirow{2}{*}{25} \\
\hline WMA3 & 175 & 150 & 145 & & 140 & \\
\hline
\end{tabular}


Particularmente no caso da WMA1, tais níveis de temperaturas de usinagem e de compactação pareciam ser significativamente baixos, mas González-León et al. (2009), por exemplo, apresentam estudos com Cecabase $\mathrm{RT}^{\oplus}$ em que as misturas mornas puderam ser compactadas em cerca de 90 a $115^{\circ} \mathrm{C}$ (com asfaltos convencionais), diferentemente de Ferreira (2009), que utilizou temperaturas da ordem de 120 a $130^{\circ} \mathrm{C}$ na compactação de misturas mornas deste tipo.

Por outro lado, no caso da WMA2 e da WMA3, decidiu-se arbitrariamente que a redução da temperatura de compactação seria da ordem de $25^{\circ} \mathrm{C}$, temendo-se que uma diminuição maior pudesse interferir significativamente nas propriedades das misturas estudadas.

\subsection{USINAGEM EM LABORATÓRIO}

O processo de usinagem no LTP/EPUSP era realizado em uma misturadora dotada de um tacho (com capacidade para usinar cerca de $15 \mathrm{~kg}$ de mistura asfáltica por vez), de um sistema de pás giratórias automáticas e de aquecimento por chama, conforme apresentado na Figura 32. Cabe mencionar que o LTP/EPUSP adota como procedimento usual a manutenção das misturas asfálticas em estufa por duas horas após a usinagem, na temperatura que deverá ocorrer a compactação do material.

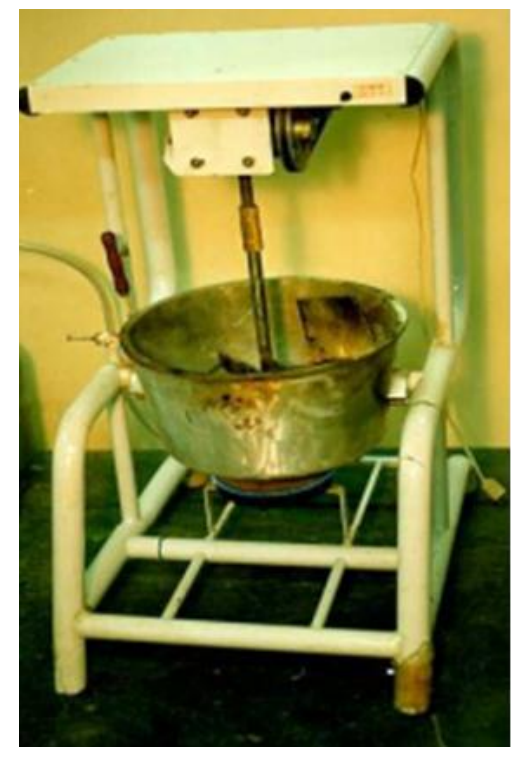

Figura 32 - Misturadora para usinagem de misturas asfálticas no LTP/EPUSP Foto: Edson de Moura 


\subsection{DOSAGEM / PARÂMETROS VOLUMÉTRICOS}

As dosagens das misturas a quente foram realizadas por método Marshall (DNER ME043/95 e NBR 12891). Para tanto, foram moldados CPs com compactação em 75 golpes por face. Os ensaios de dosagem da HMA1 e HMA2 foram conduzidos no laboratório do CPR/CCR (compactação automática), enquanto que os da HMA3 foram feitos no laboratório da Basalto/Estrutural (compactação manual). Com os resultados dos testes, foram então calculados os seguintes parâmetros volumétricos: massa específica aparente (MEA) da mistura compactada; massa específica máxima teórica (MEMT); volume de vazios (VV); vazios do agregado mineral (VAM) e relação betume $x$ vazios (RBV). Cabe mencionar que a escolha do teor de projeto se deu a partir do critério de $4 \%$ de vazios para as misturas do tipo HMA1 e HMA2 e de 5\% de vazios para a mistura HMA3.

Para as misturas mornas foram adotados os mesmos teores de ligante e as mesmas composições granulométricas indicados nos projetos de dosagem de suas respectivas misturas a quente, para verificar se o comportamento de ambas seria similar sob a mesma configuração de materiais.

\subsubsection{HMA1}

Os ensaios de dosagem da HMA1 foram realizados com três CPs Marshall por teor de ligante (teores 4,0 a 6,0\%, em intervalos de 0,5\%). A Figura 33 apresenta os resultados da dosagem Marshall e a Tabela 16 indica os valores para $o$ teor definido como sendo de projeto (denominado de "teor ótimo" por alguns técnicos). 

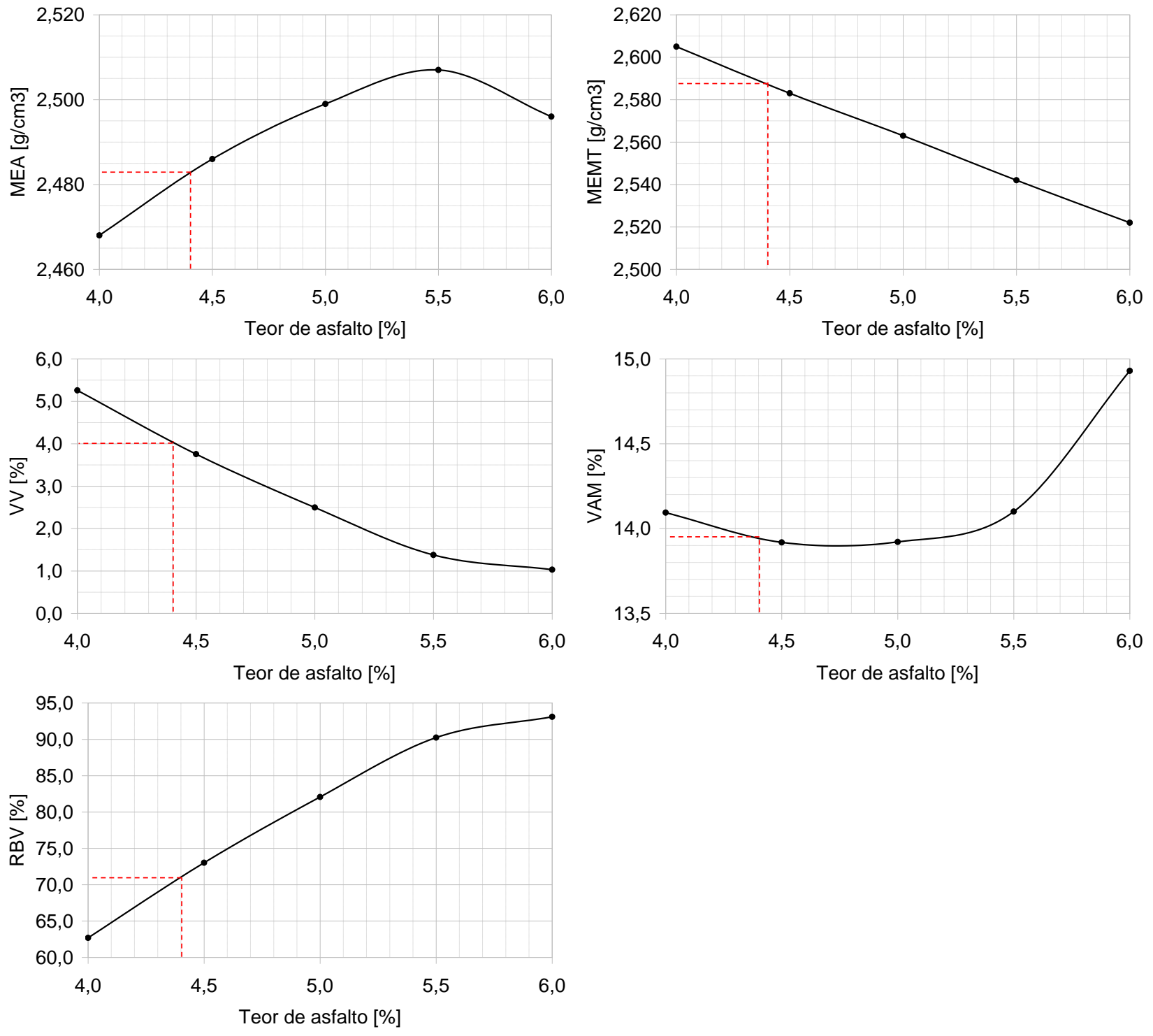

Figura 33 - Parâmetros volumétricos obtidos na dosagem Marshall da HMA1

Tabela 16 - Parâmetros volumétricos do teor de projeto ("ótimo") da HMA1

\begin{tabular}{clcc}
\hline Parâmetro & Norma & Resultado & $\begin{array}{c}\text { Limites } \\
\text { (especificação) }\end{array}$ \\
\hline $\begin{array}{c}\mathrm{MEA} \\
{\left[\mathrm{g} / \mathrm{cm}^{3}\right]}\end{array}$ & AASHTO T166 & 2,484 & - \\
\hline $\begin{array}{c}\mathrm{MEMT} \\
{\left[\mathrm{g} / \mathrm{cm}^{3}\right]}\end{array}$ & Asphalt Institute & 2,588 & - \\
\hline $\begin{array}{c}\mathrm{VV} \\
{[\%]}\end{array}$ & Asphalt Institute & 4,0 & $\begin{array}{c}\text { entre 3 e 5 } \\
\text { (Asphalt Institute) }\end{array}$ \\
\hline $\begin{array}{c}\text { VAM } \\
{[\%]}\end{array}$ & Asphalt Institute & 13,9 & $\begin{array}{c}\text { mínimo 14,0 } \\
\text { (Asphalt Institute) }\end{array}$ \\
\hline $\begin{array}{c}\text { RBV } \\
{[\%]}\end{array}$ & Asphalt Institute 65 e 75 \\
(Asphalt Institute)
\end{tabular}


Observa-se que o valor de VAM da mistura asfáltica com o teor de projeto escolhido se mostrou ligeiramente abaixo do limite mínimo estabelecido pelo Asphalt Institute e, dentro deste contexto, vale mencionar que valores muito baixos de VAM podem levar as misturas asfálticas a ter problemas de durabilidade em pista, como citam Brown et al. (2009).

Segundo Bernucci et al. (2008), em misturas asfálticas contínuas densas a faixa de teor de ligante de projeto normalmente fica entre 4,5 a 6,0\%, dependendo da forma dos agregados, da massa específica destes materiais pétreos, da viscosidade e tipo de ligante, podendo haver variações em torno destes valores. Com isto, nota-se que a HMA1 está na porção mais "seca" da faixa de teores de asfalto indicada por aqueles autores, entendendo-se que se trata de uma mistura com baixo teor de ligante, podendo ser considerada como "pobre" em asfalto.

\subsubsection{HMA2}

Os ensaios de dosagem da HMA2 foram realizados com três CPs Marshall por teor de ligante (teores 3,5 a 5,5\%, em intervalos de 0,5\%). A Figura 34 apresenta os resultados na dosagem Marshall e a Tabela 17 indica os valores para o teor definido como sendo de projeto ("ótimo"). 

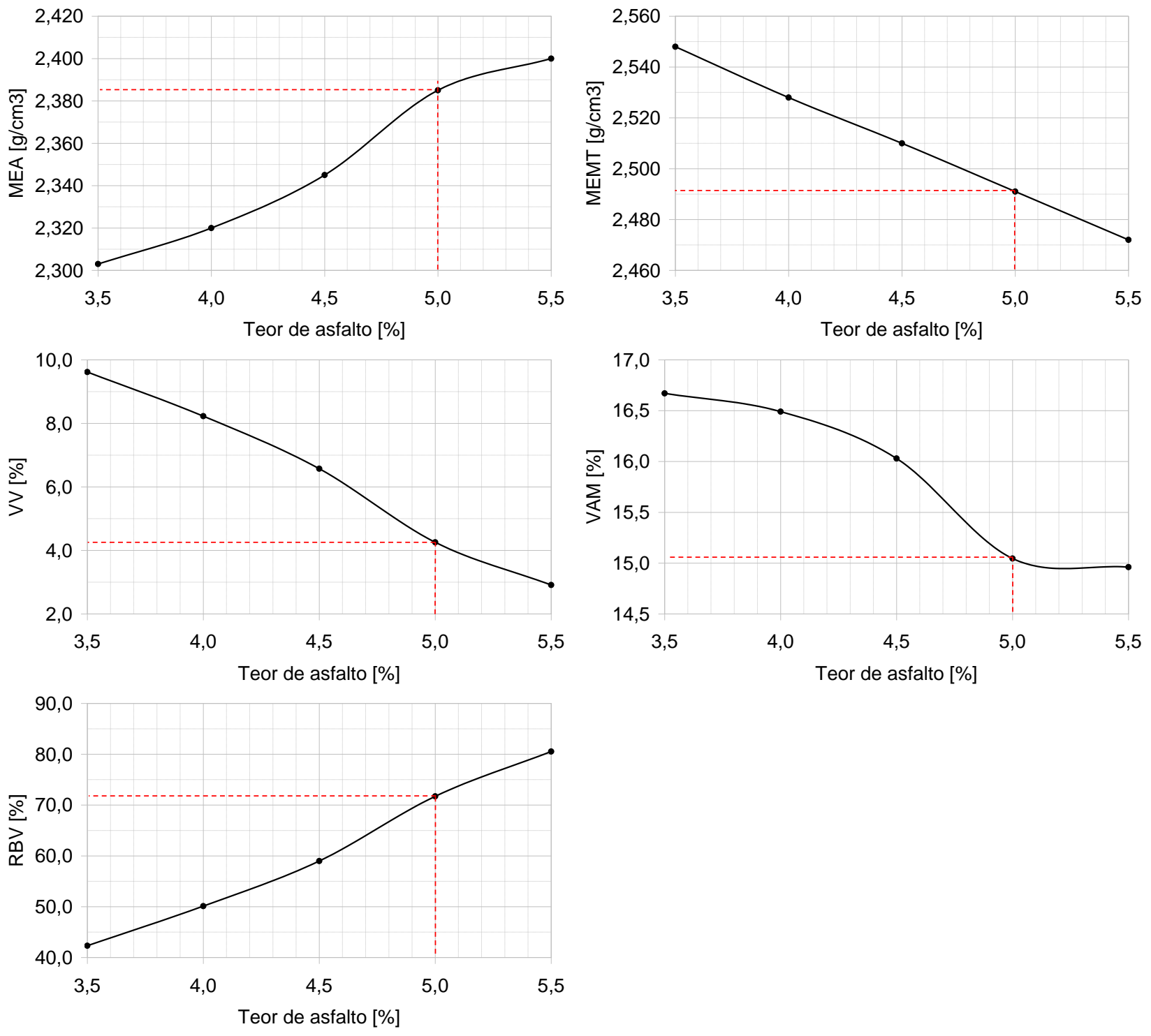

Figura 34 - Parâmetros volumétricos obtidos na dosagem Marshall da HMA2

Tabela 17 - Parâmetros volumétricos do teor de projeto ("ótimo") da HMA2

\begin{tabular}{|c|c|c|c|}
\hline Parâmetro & Norma & Resultado & $\begin{array}{c}\text { Limites } \\
\text { (especificação) }\end{array}$ \\
\hline $\begin{array}{c}\mathrm{MEA} \\
{\left[\mathrm{g} / \mathrm{cm}^{3}\right]}\end{array}$ & AASHTO T166 & 2,385 & 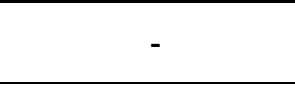 \\
\hline $\begin{array}{l}\mathrm{MEMT} \\
{\left[\mathrm{g} / \mathrm{cm}^{3}\right]}\end{array}$ & Asphalt Institute & 2,491 & - \\
\hline $\begin{array}{l}\mathrm{VV} \\
{[\%]}\end{array}$ & Asphalt Institute & 4,2 & $\begin{array}{c}\text { entre } 3 \text { e } 5 \\
\text { (Asphalt Institute) }\end{array}$ \\
\hline $\begin{array}{l}\text { VAM } \\
{[\%]}\end{array}$ & Asphalt Institute & 15,1 & $\begin{array}{c}\text { mínimo } 14,0 \\
\text { (Asphalt Institute) }\end{array}$ \\
\hline $\begin{array}{c}\text { RBV } \\
{[\%]} \\
\end{array}$ & Asphalt Institute & 71,8 & $\begin{array}{c}\text { entre } 65 \text { e } 75 \\
\text { (Asphalt Institute) }\end{array}$ \\
\hline \multicolumn{2}{|c|}{$\begin{array}{c}\text { Teor de ligante de projeto ("ótimo") } \\
{[\%]}\end{array}$} & 5,0 & \\
\hline
\end{tabular}




\subsubsection{HMA3}

Os ensaios de dosagem da HMA3 foram realizados com três CPs Marshall por teor de ligante (teores 5,0 a 7,0\%, em intervalos de 0,5\%). A Figura 35 apresenta os resultados na dosagem Marshall e a Tabela 18 indica os valores para o teor definido como sendo de projeto ("ótimo").
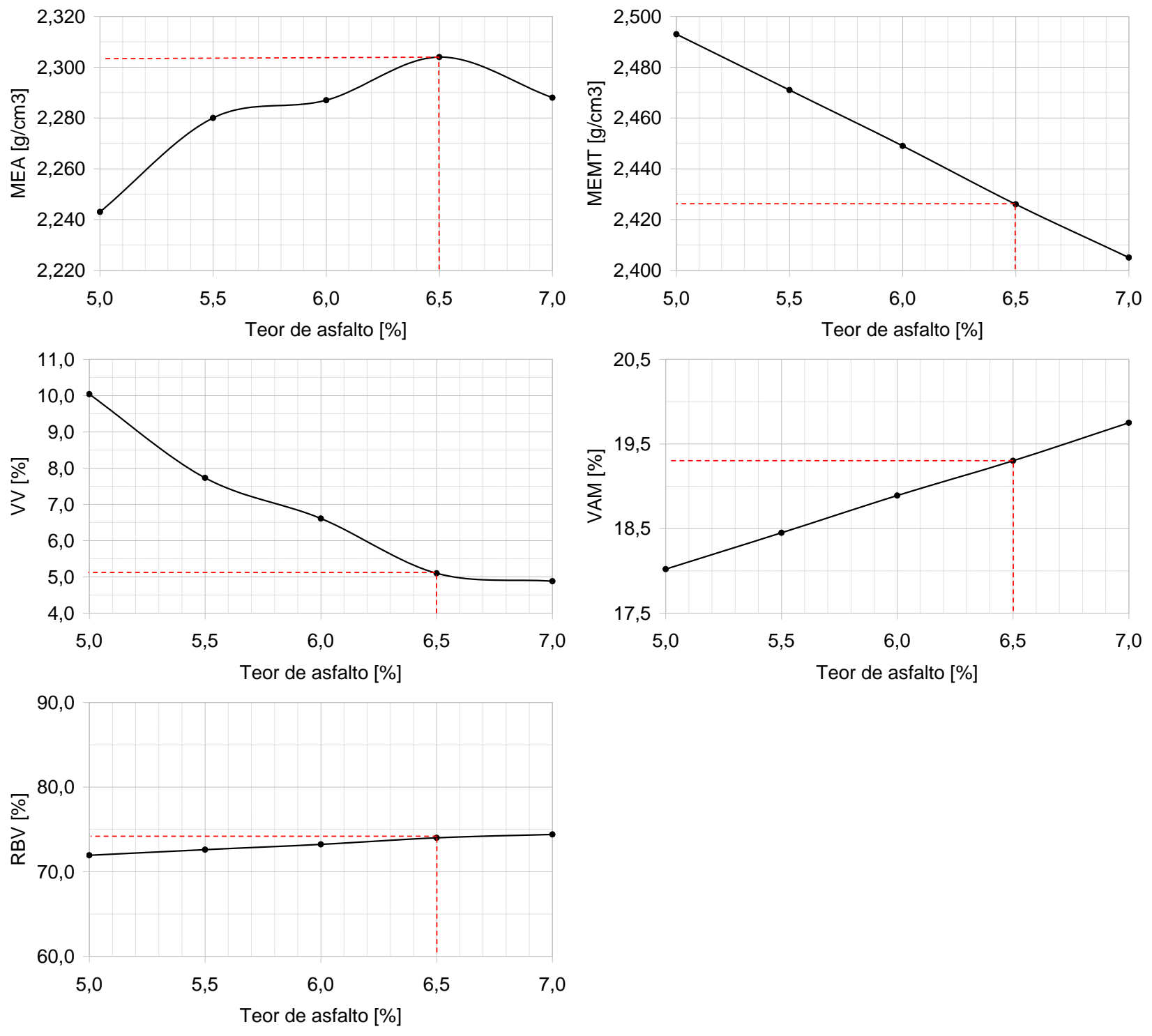

Figura 35 - Parâmetros volumétricos obtidos na dosagem Marshall da HMA3 
Tabela 18 - Parâmetros volumétricos do teor de projeto ("ótimo") da HMA3

\begin{tabular}{cccc}
\hline Parâmetro & Norma & Resultado & $\begin{array}{c}\text { Limites } \\
\text { (especificação) }\end{array}$ \\
\hline $\begin{array}{c}\text { MEA } \\
{\left[\mathrm{g} / \mathrm{cm}^{3}\right]}\end{array}$ & AASHTO T166 & 2,304 & - \\
\hline $\begin{array}{c}\text { MEMT } \\
{\left[\mathrm{g} / \mathrm{cm}^{3}\right]}\end{array}$ & AASHTO T209 & 2,427 & - \\
\hline $\begin{array}{c}\mathrm{V} V \\
{[\%]}\end{array}$ & AASHTO T166 & 5,1 & $\begin{array}{c}\text { entre 4 e 6 } \\
\text { (DNIT ES112) }\end{array}$ \\
\hline $\begin{array}{c}\text { VAM } \\
{[\%]}\end{array}$ & AASHTO T166 & 19,3 & $\begin{array}{c}\text { mínimo 16,0 } \\
\text { (DNIT ES112) }\end{array}$ \\
\hline $\begin{array}{c}\text { RBV } \\
{[\%]}\end{array}$ & AASHTO T166 & 73,8 & $\begin{array}{c}\text { entre 65 e 78 } \\
\text { (DNIT ES112) }\end{array}$ \\
\hline Teor de ligante de projeto ("ótimo") & 6,5 & \\
{$[\%]$} & &
\end{tabular}

\subsubsection{Comparativo: Dosagem / Parâmetros volumétricos}

Para melhor visualização, a Figura 36 apresenta, reunidos em único gráfico, os parâmetros volumétricos no teor de projeto das misturas asfálticas a quente da presente pesquisa.

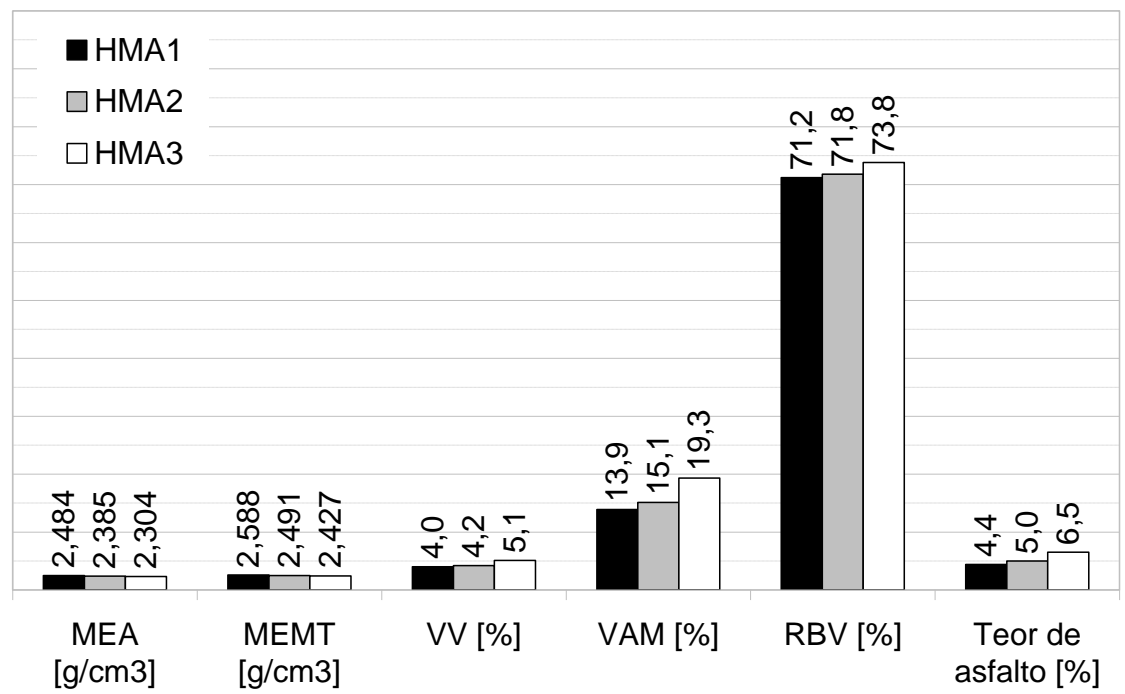

Figura 36 - Parâmetros volumétricos das misturas a quente no teor de projeto 


\subsection{ENSAIOS DE PROPRIEDADES MECÂNICAS E TESTES COMPLEMENTARES}

\subsubsection{Compactação}

Segundo Bernucci et al. (2009), para que a compactação de uma mistura asfáltica ocorra de maneira eficiente é preciso atentar para um aspecto fundamental que é a temperatura adequada deste material no momento da densificação, pois se a temperatura for muito baixa o ligante se torna plástico e pegajoso, dificultando a compressão da mistura e a obtenção de um estado mais denso. Tendo-se em vista que a produção e a compactação de misturas mornas ocorrem em temperaturas mais baixas que o usual, este é um importante parâmetro a ser verificado.

O VV de uma mistura asfáltica provavelmente é o fator mais importante que afeta o desempenho de um pavimento ao longo de sua vida de serviço (BROWN et al., 2009), pois tem relação com algumas características requeridas quanto à textura e à durabilidade (resistência à água, fadiga e deformação permanente) da camada asfáltica (DELORME et al., 2007). Dentro deste contexto, um maior volume de vazios pode levar as misturas asfálticas a ter maior deformação e menor resistência (HUBER e DECKER, 1995).

A densificação foi avaliada em laboratório por meio da determinação da massa específica aparente, ou densidade específica, e posterior cálculo do VV por pesagem hidrostática (AASHTO T166-07) de CPs das misturas asfálticas compactadas em compactador Marshall, em mesa compactadora e em prensa de cisalhamento giratório. Assim, quanto maior a porcentagem de vazios, sob uma determinada energia pré-fixada, maior seria a dificuldade de densificação.

A compactação Marshall dos primeiros CPs da WMA1 indicou que estas pareciam ser ligeiramente mais difíceis de densificar do que a HMA1. Assim, tendose em mente que um acréscimo da quantidade de ligante pudesse melhorar a lubrificação (e, por consequência, a compactação) e que no Brasil existe uma faixa de tolerância da quantidade de asfalto adicionada a uma mistura em usina ( $\pm 0,3 \%)$, alguns ensaios de compactação também foram realizados com misturas mornas em que houve aumento do teor de ligante em relação ao de projeto, dentro e fora da faixa aceitável em usina. Assim, além da mistura no teor de projeto, a WMA1 foi preparada com $+0,3 \%$ e $+0,6 \%$ de asfalto (WMA1 TP+0,3\% e WMA1 TP+0,6\%) e, para comparação, a WMA2 também foi testada com $+0,2 \%$ e com $+0,4 \%$ de ligante 
(WMA2 TP+0,2\% e WMA2 TP+0,4\%). Todavia, como o aumento da quantidade de asfalto pode gerar problemas de deformação permanente, mesmo dentro do admissível em usinas (BERNUCCl et al., 2008), optou-se também nesta pesquisa por realizar ensaios de afundamento de trilha de roda de tais misturas mais ricas em ligante.

\subsubsection{Marshall}

As normas do DNIT ES031/06 e ES112/09 determinam limites mínimos e máximos de porcentagem de vazios que misturas asfálticas densas convencionais e gap-graded com asfalto-borracha, respectivamente, devam apresentar após a compactação Marshall (DNER ME043/95). Para os concretos asfálticos, o VV indicado para camada de rolamento é entre 3 a $5 \%$, enquanto na semidescontínua com borracha este é entre 4 a $6 \%$.

Para esta pesquisa foram preparados CPs em compactador Marshall automático, com a moldagem feita com 75 golpes por face. Após esfriamento e desmoldagem, estes CPs foram então submetidos à pesagem hidrostática, permitindo que houvesse o cálculo da MEA e do VV (AASHTO T166-07), onde o valor da MEMT foi obtido por ensaio RICE (AASHTO T209-99).

\subsubsection{Mesa compactadora}

Nesta pesquisa avaliou-se também a densificação ou habilidade de compactação das misturas asfálticas em mesa compactadora francesa, em que a densificação é feita por rolagem (como em campo), diferentemente do sistema Marshall, em que a compactação é feita por impacto. Para tanto, foram moldados CPs em formato de placas em mesa compactadora modelo LPC (Figura 37), seguindo as recomendações da norma europeia EN 12697-33 (2003a). 


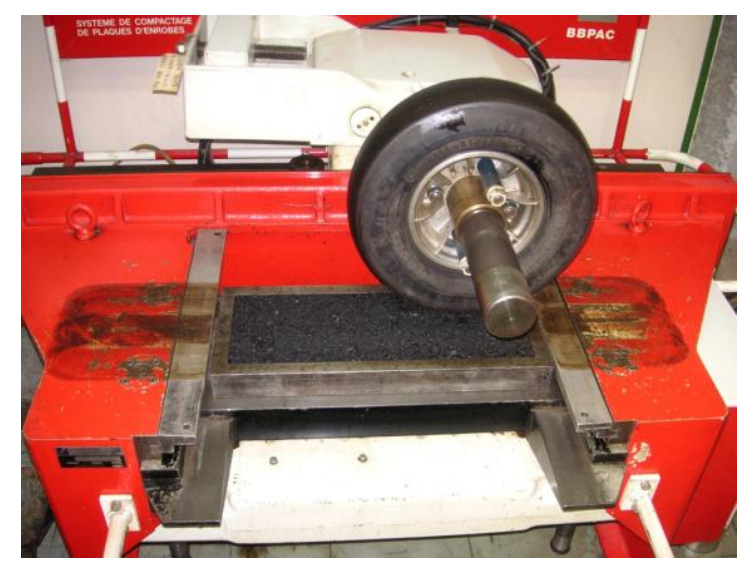

Figura 37 - Compactação na mesa compactadora francesa do LTP/EPUSP

Neste sistema, a compactação da mistura asfáltica se dá por rolagem, através de uma sequência de passagens de um pneu padronizado com pressão variando entre 0,1 e 0,6 MPa, e carga no eixo de 1 a $5 \mathrm{kN}$.

Para melhor comparação de dimensões, a Figura 38 ilustra a diferença de tamanho de um CP moldado em mesa compactadora (e já testado posteriormente em simulador de tráfego) e outro em compactador Marshall.

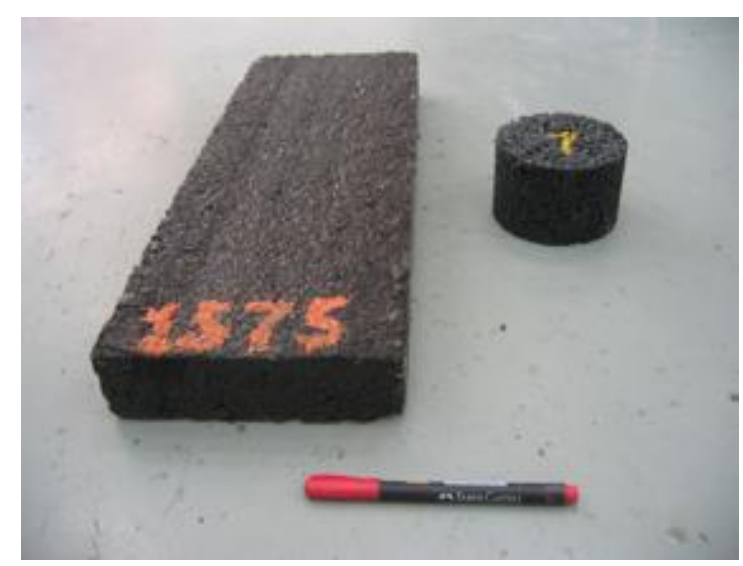

Figura 38 - Corpo de prova moldado em mesa compactadora (e já testado) e em Marshall à esquerda e à direita, respectivamente

O VV das placas foram determinados por pesagem hidrostática (AASHTO T166-07). Cabe mencionar que as bordas de cada placa foram eliminadas, a fim de se obter uma amostra mais homogênea e evitando eventuais efeitos de borda, sendo utilizada somente a parte central da placa, como mostra a Figura 39. 


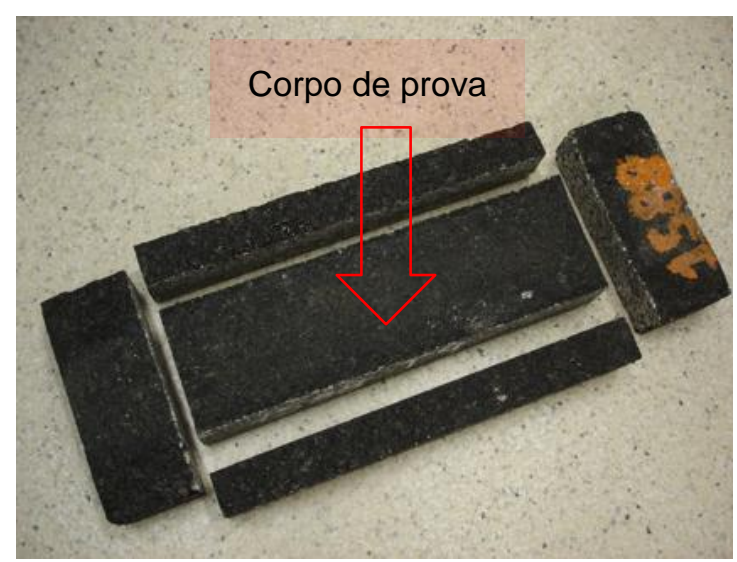

Figura 39 - Exemplar de corpo de prova para verificação da compactação em mesa compactadora

$\mathrm{Na}$ França têm-se especificações relativas aos volumes de vazios na compactação de diferentes tipos de mistura asfáltica em mesa compactadora. Podese dizer que as graduações francesas que mais se aproximam daquelas das misturas asfálticas estudadas na presente pesquisa são a BBSG (Béton Bitumineux Semi-Grenu), que se trata de uma mistura contínua densa, e a BBTM (Béton Bitumineux Très Mince), que se refere a uma mistura semidescontínua delgada (DELORME et al., 2007). A Figura 40 apresenta curvas típicas destas granulometrias, em comparação com o concreto asfáltico - faixa C DNIT - e com o gap-graded 3/8" - faixa do Caltrans - utilizados nesta pesquisa (valores médios).

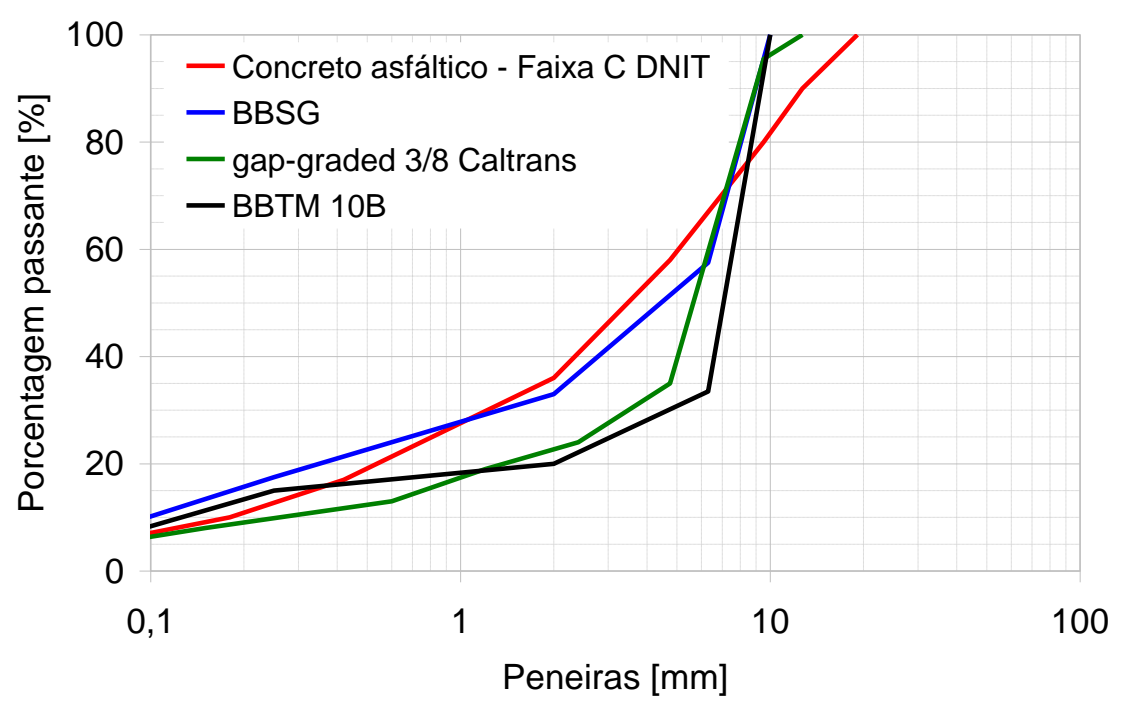

Figura 40 - Curvas granulométricas típicas BBSG, BBTM 10B, faixa C DNIT e gap-graded 3/8" Caltrans

Nas normas francesa e europeia (NF P 98-130, 1999a e EN 13108-2, 2006), as misturas asfálticas BBSG 3 0/14 devem apresentar VV entre 5 a $8 \%$ em placas 
de $10 \mathrm{~cm}$ de espessura, enquanto as misturas BBTM 10B devem conter um VV de 9 a $16 \%$ em placas com $5 \mathrm{~cm}$ de espessura. Entretanto, como mencionado anteriormente, o confronto de resultados desta pesquisa com os limites de tais especificações deve ser encarado como uma aproximação.

\subsubsection{Prensa de cisalhamento giratório}

Em muitos locais, desde a década de 90, os compactadores giratórios vêm substituindo os equipamentos Marshall, como método de compactação, para fins de dosagem de misturas asfálticas. A principal diferença entre ambos é a forma de compactação, onde enquanto que no Marshall ocorre por impacto, nos giratórios é realizada por amassamento (em giros), vencendo a resistência ao cisalhamento do esqueleto pétreo para alteração da posição das partículas e redução dos vazios com ar da mistura asfáltica.

Nesta pesquisa a habilidade de compactação também foi observada por meio de ensaios em prensa de cisalhamento giratório francesa (presse à cisaillement giratoire - PCG), segundo a especificação NF P 98-252 (1999b), cujo equipamento está ilustrado na Figura 41.

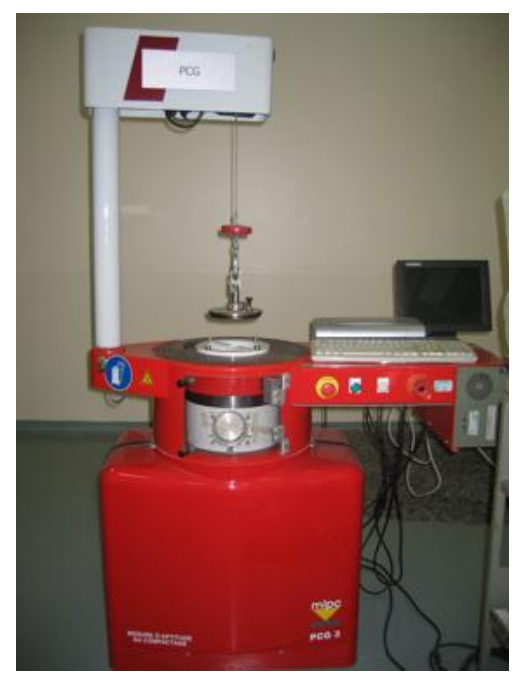

Figura 41 - Compactador giratório, modelo PCG francesa, do LTP/EPUSP

Para cada tipo de mistura asfáltica são moldados três CPs, onde cada um possui $15 \mathrm{~cm}$ de diâmetro e cerca de $15 \mathrm{~cm}$ altura, com massa de pouco mais de 
6 kg. A Figura 42 mostra a diferença de dimensões de um CP moldado na PCG e outro no Marshall.

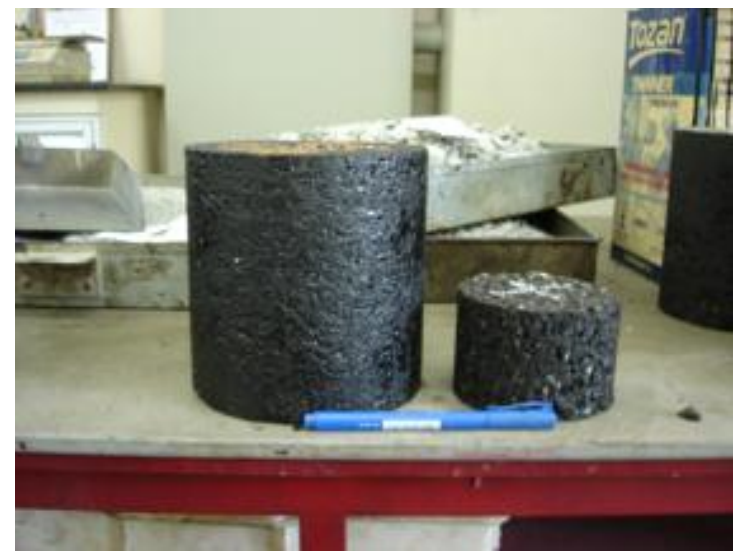

Figura 42 - Corpo de prova moldado em PCG e em equipamento Marshall à esquerda e à direita, respectivamente

Dentro do programa de ensaios de dosagem de misturas asfálticas na França prevê-se que, na PCG, as misturas BBSG 3 0/14 devem apresentar um VV entre 4 e 9\% aos 80 giros (NF P 98-130, 1999a), enquanto as misturas BBTM 10B devam conter um VV entre 18 e 25\% aos 25 giros (EN 13108-2, 2006). Entretanto, diferentemente do método de dosagem francês, a especificação SUPERPAVE dos Estados Unidos contempla a correção da MEA obtida na prensa, por meio da realização de teste complementar para medida deste parâmetro (por pesagem hidrostática, por exemplo) para a determinação do VV em equipamento giratório. Isto porque o cálculo da MEA através deste tipo de equipamento assume que o CP tem uma superfície lisa (o que não representa a realidade), e as irregularidades superficiais fazem com que o volume calculado do CP seja menor do que na condição de superfície lisa. Dentro deste contexto, deve-se fazer o cálculo do fator de correção, que é tido como a razão entre a MEA medida pela AASHTO T166-07, ASTM D1188-07 ou D2726-10 e a MEA indicada no compactador giratório (SUPERPAVE, 2001).

Como a presente pesquisa considera o VV corrigido, segundo apontado na especificação SUPERPAVE, por meio de pesagem hidrostática do CP após 200 giros, não é possível comparar aqui os resultados obtidos com as especificações francesa de BBSG e de BBTM, que não prevêem tal correção. 


\subsubsection{Resistência à tração}

A resistência à tração $(R T)$ é um parâmetro muito utilizado no Brasil para a caracterização de misturas asfálticas, tendo sido adotado desde 1972 para tal finalidade. Nesta pesquisa, a RT foi avaliada por meio de ensaio de carregamento estático por compressão diametral, segundo as recomendações da norma NBR 15087 , a $25^{\circ} \mathrm{C}$.

Segundo a especificação do DNIT ES031/06, a RT de concretos asfálticos destinados à camada de rolamento ou de binder $\left(a 25^{\circ} \mathrm{C}\right)$ deve ser de no mínimo 0,65 MPa. Já na norma do DNIT ES112/09, as misturas asfálticas gap-graded com asfalto-borracha devem apresentar uma RT mínima de 0,50 MPa, no caso de este material ser aplicado como camada de rolamento.

Bernucci et al. (2008) mencionam que misturas asfálticas a quente recémmoldadas, ou logo após a construção em pista, geralmente apresentam valores típicos de RT entre 0,5 e 2,0 MPa, podendo haver variações nos casos em que as misturas são do tipo drenante ou têm consistência mais dura, por exemplo. Além disso, à medida que as misturas asfálticas envelhecem em pista, a RT aumenta, o que não necessariamente representa uma vantagem, uma vez que isto pode significar uma perda de flexibilidade, com aumento do módulo de resiliência.

A Figura 43 ilustra o ensaio de RT sendo realizado com uma das misturas asfálticas deste estudo.
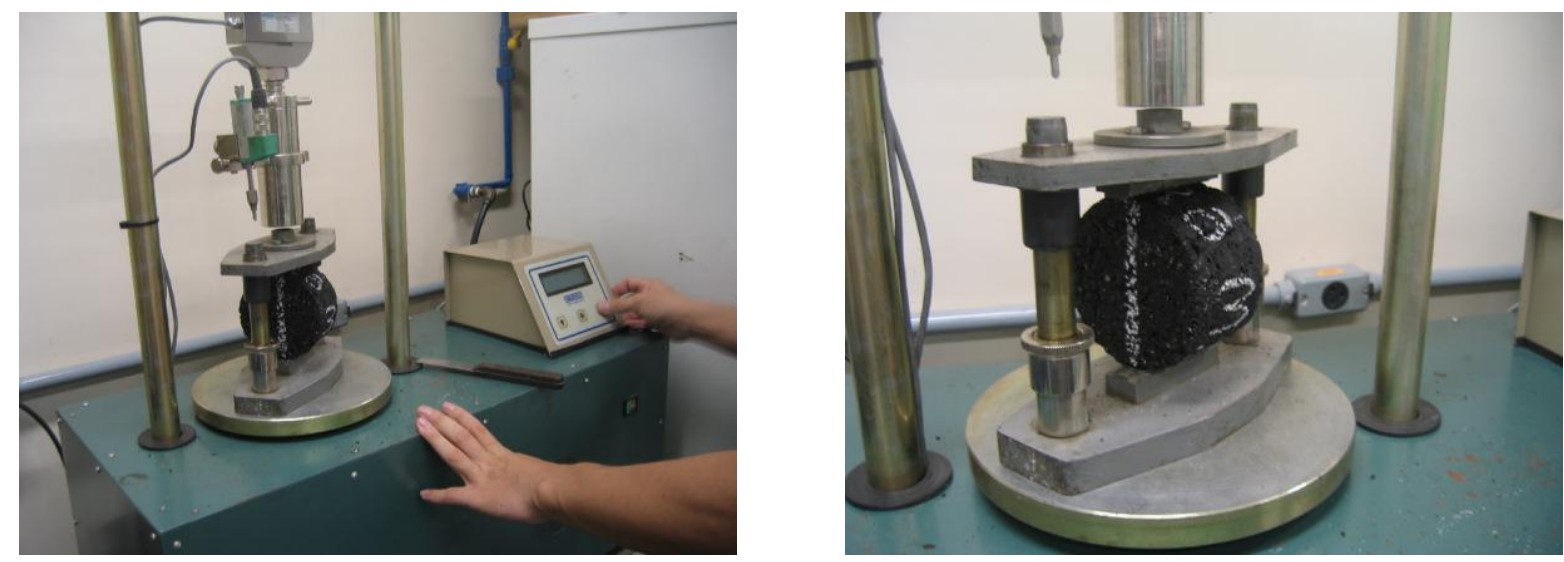

Figura 43 - Ensaio de resistência à tração por compressão diametral no LTP/EPUSP 


\subsubsection{Módulo de resiliência}

De acordo com o Asphalt Institute (2007), o módulo de um material é usado para calcular a deformação esperada quando da aplicação de uma determinada carga, seja cisalhante, dinâmica ou resiliente. No caso do módulo de resiliência (MR), o resultado de ensaio é empregado como dado de entrada no cálculo de espessuras de camadas (sistema elástico) e de coeficientes estruturais de projetos de dimensionamento de pavimentos.

Nesta pesquisa foram realizados ensaios de MR segundo as recomendações da norma DNER ME133/94. Os testes foram feitos em prensa universal, por meio de carregamento cíclico indireto (com cerca de $15 \%$ da carga máxima de ruptura) a $25^{\circ} \mathrm{C}$, sendo a aplicação de carga executada à frequência de $1 \mathrm{~Hz}$ e as leituras dos deslocamentos obtidas a partir de um LVDT (Linear Variable Differential Transducers). A Figura 44 ilustra a prensa quando da execução de ensaio de MR.
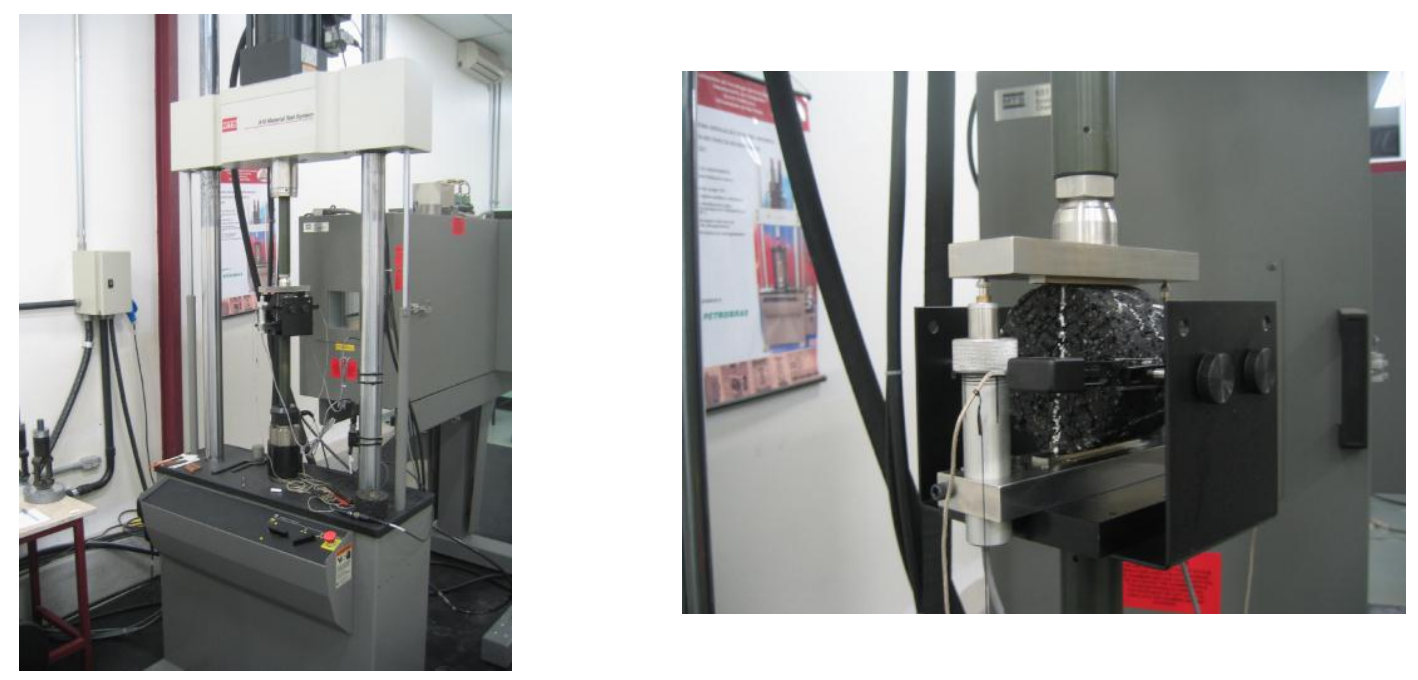

Figura 44 - Ensaio de módulo de resiliência no LTP/EPUSP

Embora as especificações brasileiras de concretos asfálticos, como a DNIT ES031/06 e a DNIT ES112/09, não estabeleçam limites de valores de MR (nem tampouco mencionem tal ensaio), este parâmetro é empregado especialmente em estudos que contemplem o comportamento estrutural de pavimentos.

Segundo Bernucci et al. (2008), o MR de misturas asfálticas a quente pode variar em função de alguns fatores como tipo de mistura, faixa granulométrica, ligante asfáltico, propriedades volumétricas, energia de compactação, temperatura de compactação, temperatura de ensaio, dentre outros. Porém, em geral, os valores 
típicos de MR são da ordem de 2.000 a $8.000 \mathrm{MPa}$ a $25^{\circ} \mathrm{C}$, sendo que as misturas com asfaltos de consistência dura apresentam os valores mais elevados. Ademais, o MR varia ao longo do tempo devido ao envelhecimento do ligante, por este sofrer um enrijecimento e transferir esta característica para o revestimento asfáltico.

\subsubsection{Deformação permanente}

De acordo com Brown et al. (2009), os revestimentos asfálticos estão sujeitos a sofrerem afundamentos com o tráfego devido à redução dos seus vazios. Uma camada asfáltica de rolamento com cerca de $10 \mathrm{~cm}$ de espessura e com vazios iniciais da ordem de 7 a $8 \%$, por exemplo, deve afundar aproximadamente $3 \mathrm{~mm}$ ao passar para 4 a $5 \%$ de vazios após dois a três anos de sua construção. Este afundamento é considerado insignificante, porém se for de maior magnitude significa que é excessivo. Além disso, a deformação permanente nestas camadas também pode ocorrer devido à fluência da mistura asfáltica ou ruptura por cisalhamento (BERNUCCl et al., 2008; BROWN et al., 2009).

Nesta pesquisa, o potencial para deformação permanente das misturas asfálticas estudadas foi verificado por meio de ensaio em simulador de tráfego francês modelo LPC, com CPs em forma de placas de $5 \mathrm{~cm}$ de espessura $\times 18 \mathrm{~cm}$ de largura $\times 50 \mathrm{~cm}$ de comprimento, moldadas conforme descrito no item 3.5.1.2.

$\mathrm{Na}$ França, os concretos asfálticos densos BBSG, por exemplo, são aplicados em pista normalmente em espessuras de camada maiores que $5 \mathrm{~cm}$, deste modo, as especificações de ensaios deste tipo de mistura no simulador de tráfego requerem que a espessura de placa testada seja de $10 \mathrm{~cm}$. Já a mistura semidescontínua BBTM é aplicada pelos franceses em espessuras delgadas e, assim, o ensaio no simulador é feito com placas de $5 \mathrm{~cm}$. No Brasil, onde os revestimentos geralmente são delgados, mesmo os de granulometria contínua, o LTP/EPUSP executa os testes no simulador francês geralmente em placas de $5 \mathrm{~cm}$ de espessura, desde que o equipamento foi instalado na década de 90 .

Após moldagem e cura de dois dias, as placas eram submetidas à simulação de tráfego também em equipamento francês modelo LPC (Figura 45), seguindo a especificação EN 12697-22 (2003b). Este aparato é composto de um eixo com pneu sob pressão e carga reguláveis, normalizadas respectivamente em 6 bar e $5.000 \mathrm{~N}$. 
O pneu rola em contato direto sobre a placa em ciclos (cada um correspondente a uma ida e uma volta, a uma frequência de $1 \mathrm{~Hz}$ ), gerando afundamentos progressivos que vão sendo lidos, em determinados intervalos, até 30.000 ciclos (Figura 46). Cabe mencionar que, a fim de impor a condição mais desfavorável e acelerar a obtenção dos resultados, o ensaio é realizado a $60^{\circ} \mathrm{C}$.

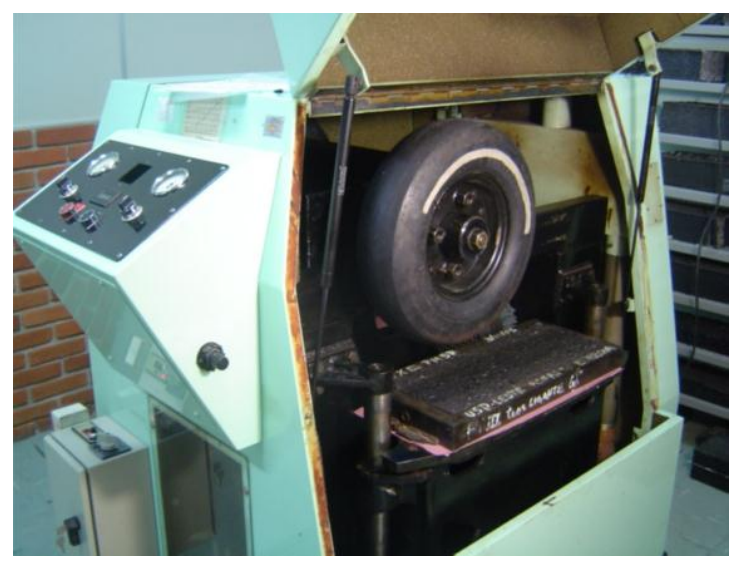

Figura 45 - Simulador de tráfego francês do LTP/EPUSP

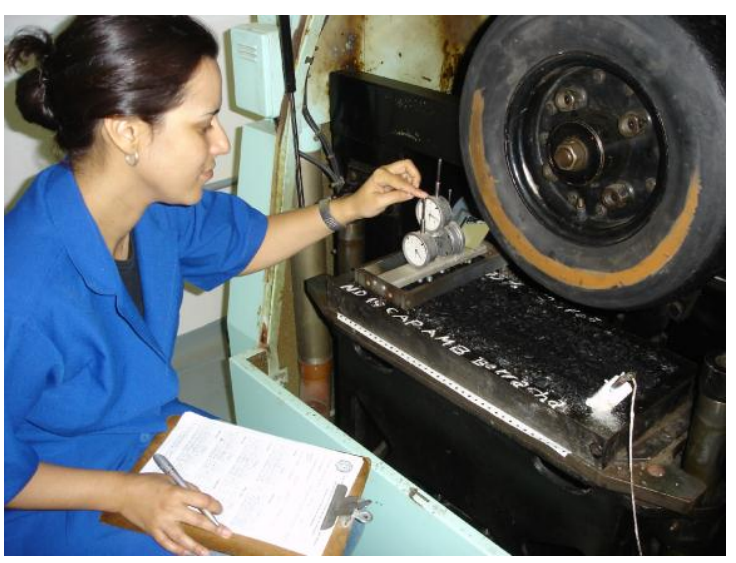

Figura 46 - Leitura de deformações permanentes no simulador de tráfego

Segundo as especificações francesa e europeia (NF P 98-130, 1999a e EN 13108-2, 2006), o afundamento em trilha de roda de misturas BBSG 3 0/14 sujeitas a tráfego pesado deve ser de no máximo 5\% após 30.000 ciclos (placas de $10 \mathrm{~cm}$ ), enquanto a de misturas BBTM 10B não deve ultrapassar $15 \%$ após 3.000 ciclos (placas de $5 \mathrm{~cm}$ ). No Brasil se tem procurado estabelecer valores máximos em torno de $5 \%$ aos 30.000 ciclos devido às condições prevalecentes no país, já que o clima é desfavorável quanto à deformação permanente, sendo este limite utilizado a partir de 1994 no LTP/EPUSP, desde os primeiros testes com este simulador no país.

Usualmente, o ensaio no simulador francês deve ser feito com um par de placas iguais, cujo resultado de afundamento corresponde a uma média ou regressão dos valores obtidos com ambas. Entretanto, em alguns casos desta pesquisa só foi possível realizar o ensaio com uma placa, devido ao montante reduzido de material disponível, tendo-se em vista que a confecção de uma placa requer o uso de cerca de $11 \mathrm{~kg}$ de massa asfáltica (enquanto com este material seria possível preparar cerca de oito a nove CPs do tipo Marshall, por exemplo). 


\subsubsection{Dano por umidade induzida}

O dano por umidade induzida é um importante parâmetro a ser verificado em estudos com misturas mornas e semimornas, já que podem estar mais sujeitas ao efeito stripping, devido à secagem menos efetiva dos agregados.

Nesta pesquisa, o efeito da água nas misturas asfálticas foi avaliado por meio da norma AASHTO T283-07, também chamado de método de Lottman modificado, embora existam também as especificações da ASTM D4867-09 e da brasileira NBR 15617. A diferença principal entre elas é que a AASHTO considera um tempo de envelhecimento da mistura asfáltica em estufa de 16 horas a $60^{\circ} \mathrm{C}$, antes da cura usual de uma a duas horas a $135^{\circ} \mathrm{C}$, empregada pela ASTM e pela NBR.

Neste trabalho foram utilizados CPs Marshall compactados até um VV de 7\% $( \pm 1 \%)$, sendo que se optou pela situação de maior severidade neste teste, com congelamento das amostras submetidas ao condicionamento à água, após saturação parcial dos vazios. A Figura 47 ilustra, resumidamente, as etapas do ensaio de dano por umidade induzida.

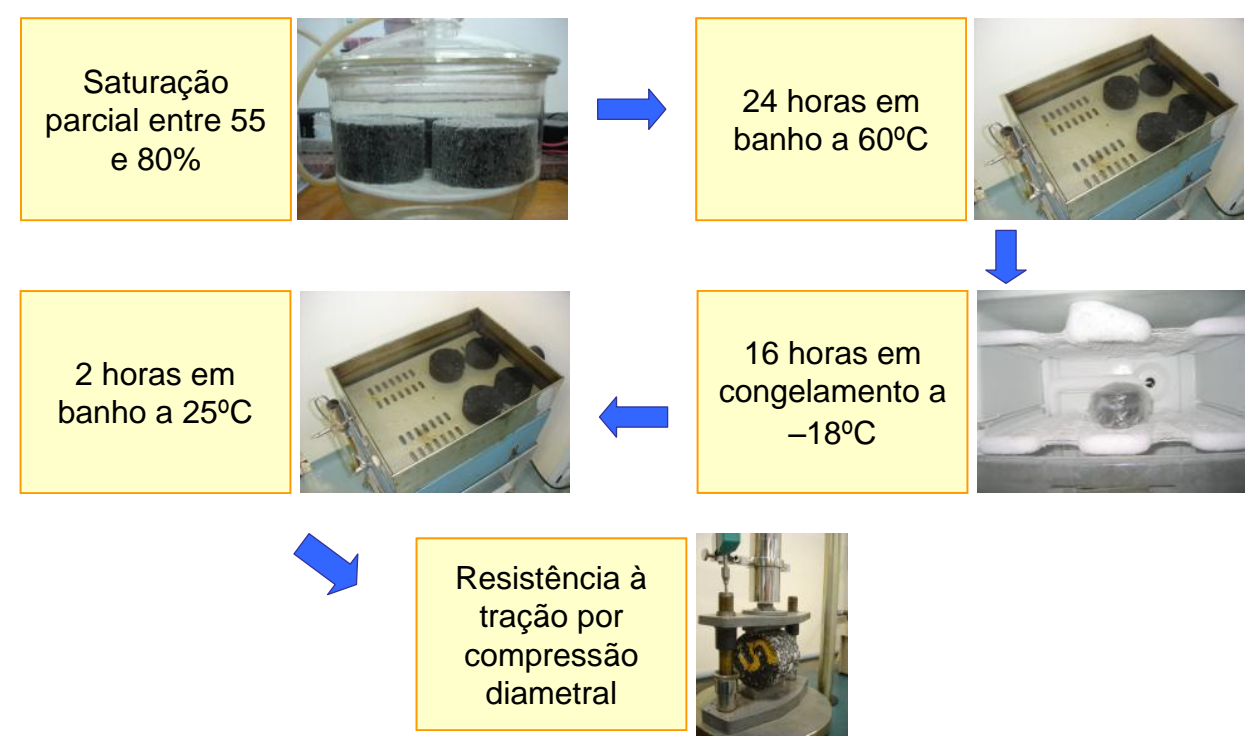

Figura 47 - Etapas do ensaio de dano por umidade induzida (da esquerda para a direita, corpos de prova submetidos a vácuo para saturação parcial, banho térmico, congelamento e resistência à tração)

As normas do DNIT ES031/06 e ES112/09 determinam que a resistência mínima retida à tração após a exposição à água, realizada pela NBR 15617, deve ser de no mínimo 0,7 (ou seja, a perda máxima de resistência deve ser de 30\% após o condicionamento, em relação ao valor de referência). 


\subsubsection{Resumo esquemático dos ensaios de propriedades mecânicas e testes complementares}

A Figura 48 apresenta um resumo esquemático dos ensaios de propriedades mecânicas e testes complementares que foram realizados nesta pesquisa.

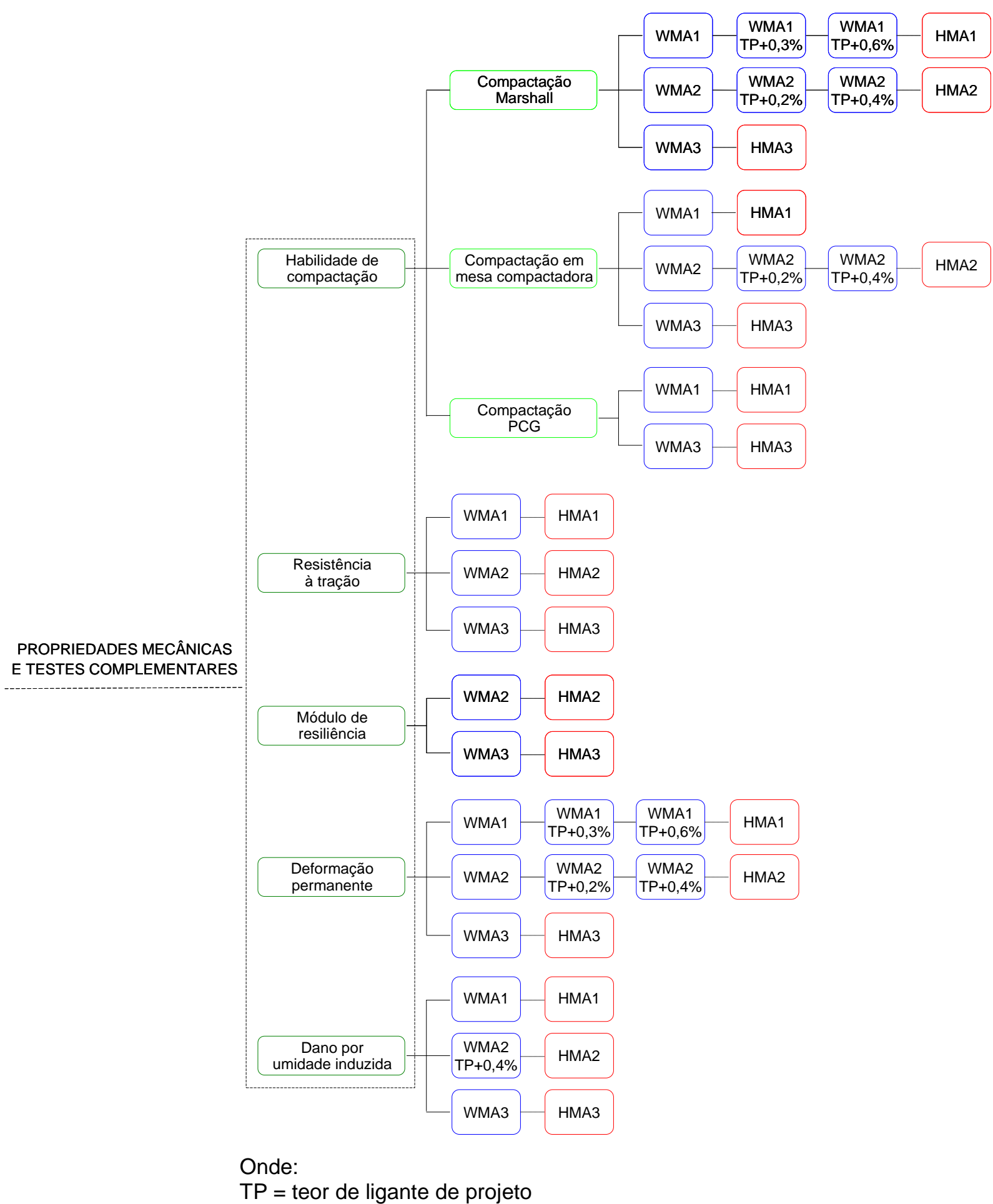

Figura 48 - Resumo esquemático dos ensaios de propriedades mecânicas e testes complementares 
Cabe mencionar que a WMA2 foi testada somente no teor de ligante $\mathrm{TP}+0,4 \%$, pois esta foi a quantidade de asfalto indicada no projeto de dosagem para o trecho experimental da Rodovia Presidente Dutra.

\subsection{RESULTADOS}

\subsubsection{Compactação}

\subsubsection{Marshall}

O ensaio para determinação da habilidade de compactação em compactador Marshall foi realizado conforme descrito no item 3.5.1.1. A Figura 49 apresenta os valores médios de VV no teste Marshall, as temperaturas de usinagem/compactação, o desvio padrão (DP) e o número de CPs ensaiados. Em seguida, têm-se os resultados da análise de variância na Tabela 19. 


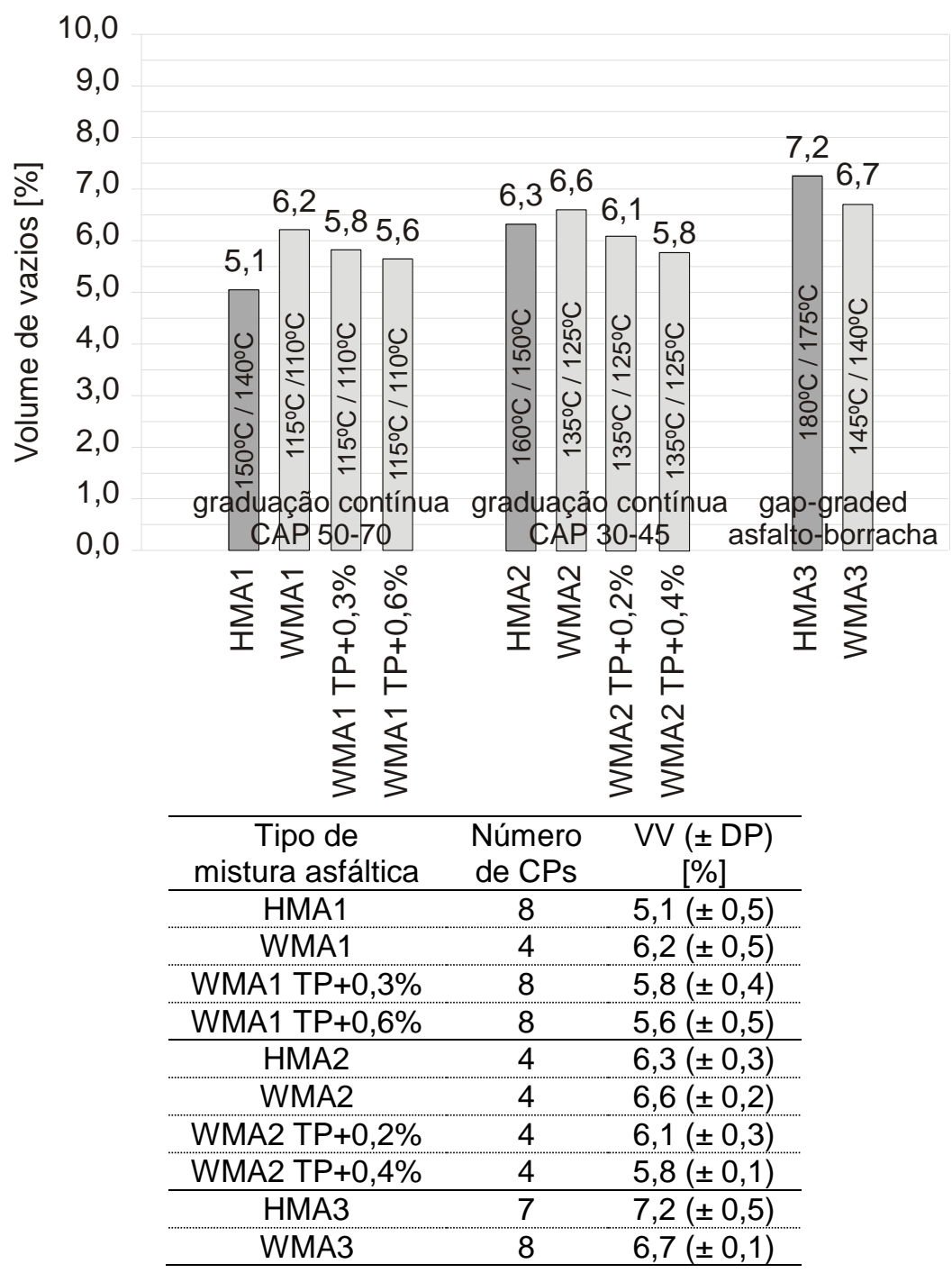

Figura 49 - Resultados da compactação em compactador Marshall

Tabela 19 - Análise de variância da compactação Marshall

\begin{tabular}{cccc}
\hline Tipo de mistura asfáltica & HMA1 & HMA2 & HMA3 \\
\hline WMA1 & ED & -- & -- \\
WMA1 TP+0,3\% & ED & -- & -- \\
WMA1 TP+0,6\% & ED & -- & -- \\
\hline WMA2 & -- & El & -- \\
\hline WMA2 TP+0,2\% & -- & El & -- \\
\hline WMA2 TP+0,4\% & -- & ED & -- \\
\hline WMA3 & -- & -- & ED \\
\hline
\end{tabular}

Nota-se que a WMA1 apresentou maior dificuldade de compactação que a HMA1, mesmo quando houve incremento do teor de ligante até acima do aceitável em usinas no Brasil. Na verdade, a adição de maior quantidade de asfalto na WMA1 (WMA1 TP+0,3\% e WMA1 TP+0,6\%) melhorou um pouco a densificação, mas não o suficiente para que a compactação da WMA1 fosse considerada estatisticamente igual à da HMA1. 
Acredita-se que as temperaturas de usinagem e de compactação da WMA1 tenham sido muito baixas em relação à HMA1 (diferença de 30 a $35^{\circ} \mathrm{C}$ ), e uma pequena elevação de tais temperaturas (em cerca de $5^{\circ} \mathrm{C}$ ) talvez já permitisse que a densificação fosse sensivelmente aumentada, visto que a WMA2 pôde ser compactada do mesmo modo que a HMA2 com uma diferença de $25^{\circ} \mathrm{C}$ entre ambas.

Além disso, entende-se que o teor de ligante da HMA1 (4,4\%) seja extremamente baixo e, quando este fator foi associado à grande redução de temperatura da WMA1, a dificuldade de compactação ficou muito evidente.

Já a WMA2 mostrou VV médio estatisticamente igual ao da HMA2, o que demonstra habilidades de compactação Marshall similares. Com o incremento do teor de ligante na WMA2 $(+0,2 \%)$, ainda dentro do que é aceitável em usinas no Brasil, verifica-se que a densificação não sofreu alteração significativa. Entretanto, quando se extrapolou tal porcentagem $(+0,4 \%)$, o VV diminuiu de maneira significativa, indicando lubrificação excessiva da mistura asfáltica. Tal demasia de ligante poderia então ser evidenciada no ensaio de deformação permanente, já que este parâmetro sofre grande influência da quantidade de asfalto na mistura.

Por fim, na situação das misturas 3 , o VV médio de ambas foi considerado estatisticamente diferente, com a WMA3 apresentando uma habilidade de compactação ligeiramente maior que a HMA3. Entretanto, entende-se que o VV de ambas seja similar, havendo tal diferença estatística devido ao fato da WMA3 ter tido uma variabilidade muito pequena em torno de sua média.

Embora não tenha sido avaliada a WMA3 com maior teor de asfalto, os resultados permitem ainda concluir que tais misturas apresentariam menor VV e, portanto, sua densificação seria ainda maior que a da HMA3, mas a questão do afundamento em trilha de roda poderia ficar comprometida.

\subsubsection{Mesa compactadora}

O ensaio para determinação da habilidade de compactação em mesa compactadora foi realizado conforme descrito no item 3.5.1.2, sendo os resultados apresentados na Figura 50. Cabe mencionar que, devido ao volume significativo de 
material necessário para a preparação de placas neste equipamento, foi moldado somente um CP de cada mistura asfáltica para tal finalidade.

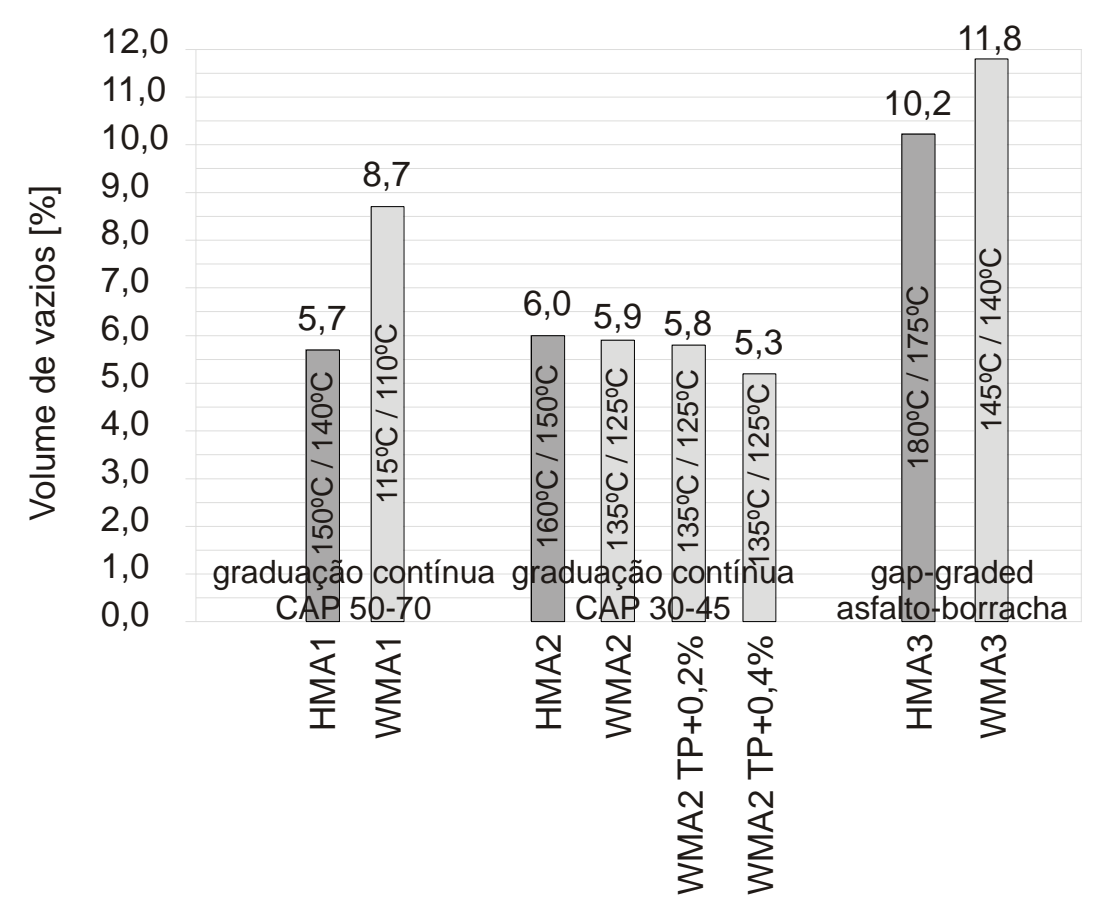

Figura 50 - Resultados da compactação em mesa compactadora

Observa-se que, seguindo a tendência do item anterior (Marshall), a WMA1 apresentou maior dificuldade de compactação que a HMA1 no sistema de rolagem. Nota-se que a temperatura de compactação indicada em González-León et al. (2009) é baixa $\left(110^{\circ} \mathrm{C}\right)$, em que a maior viscosidade do ligante impede que a compactação por rolagem ocorra com eficiência. Já no Marshall, o impacto promove maiores pressão e capacidade de densificar, mesmo com o ligante mais viscoso. Além disso, novamente há a percepção que a quantidade de ligante $(4,4 \%)$ também é baixa.

Por outro lado, no caso da WMA2 pode-se considerar que a densificação ocorreu do mesmo modo que com a HMA2, situação similar de quando houve um leve aumento do teor de ligante, dentro do aceitável em usinas no Brasil (WMA2 TP+0,2\%). Já quando o incremento da quantidade de asfalto ficou acima do tolerável, a densificação por compactação aumentou, mas o potencial à deformação permanente poderia também se elevar significativamente.

Estes resultados mostram a necessidade de se aumentar a temperatura de compactação de 110 para $125^{\circ} \mathrm{C}$ (WMA1 para WMA2) nas misturas mornas com asfalto convencional e aditivos surfactantes. A viscosidade do ligante, neste caso da 
WMA2, possibilitou maiores lubrificação entre partículas e possibilidade de densificação.

Já as misturas semidescontínuas gap-graded com asfalto-borracha, WMA3 e HMA3, se mostraram igualmente mais difíceis de compactar por rolagem do que aquelas densas. Tal fato também foi constatado em uma pesquisa laboratorial realizada por Dantas Neto et al. (2006), onde os autores empregaram maior energia de compactação para conseguir densificar as misturas gap-graded com asfalto modificado no sistema de rolagem, em comparação com uma mistura contínua. Porém, como será comentado no item 4.2.4.5, ao final desta pesquisa notou-se que misturas com granulometrias que apresentem descontinuidade devem ser compactadas por rolagem em temperaturas mais baixas que aquelas usualmente recomendadas, para que a densificação ocorra de maneira eficiente e, com isto, o VV destas misturas deve ser efetivamente menor.

Por fim, tomando-se o VV recomendado nas especificações francesas de moldagem em mesa compactadora, para as misturas BBSG 3 0/14 (entre 5 e 8\%) e BBTM 10B (entre 9 a 16\%), nota-se que somente a WMA1 ficou fora de tais limites, evidenciando sua deficiência de ligante e de temperatura na compactação.

\subsubsection{Prensa de cisalhamento giratório}

O ensaio de compactação em prensa de cisalhamento giratório (PCG) foi realizado conforme descrito no item 3.5.1.3. A partir dos dados volumétricos indicados pelo equipamento, e da pesagem hidrostática dos CPs moldados (AASHTO T166-07), foi possível corrigir o VV e plotar a curva média VV x Giros, indicada na Figura 51. Cabe mencionar que as misturas 2 não foram testadas devido à inoperabilidade do equipamento na época dos ensaios. 


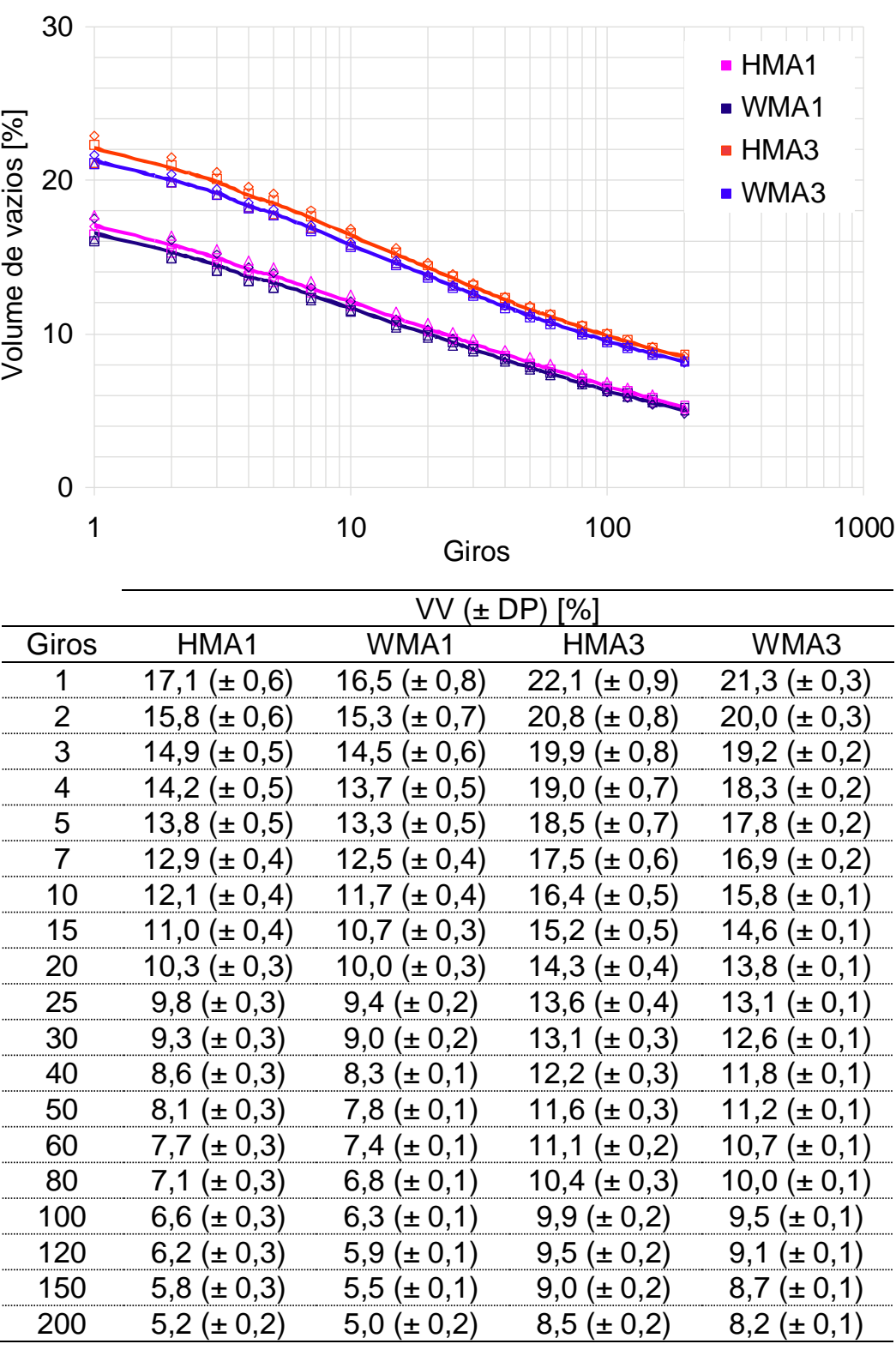

Figura 51 - Evolução da compactação na prensa de cisalhamento giratório

Nota-se que praticamente não houve variação do nível de compactação com a redução de temperatura, tanto entre a HMA1 e a WMA1, quanto entre a HMA3 e a WMA3. O fato é que a PCG é sensível à composição granulométrica (incluindo os aspectos relativos à quantidade de finos e à angularidade do esqueleto mineral) e também ao teor de ligante (DELORME et al., 2007), mas não consegue evidenciar diferenças relativas à mudança de temperatura em uma mistura asfáltica.

Maillard-Nunes et al. (2009) fizeram um estudo laboratorial com misturas mornas (tecnologia de aditivo surfactante), comparando seu comportamento à compactação com o das misturas em temperatura convencional, e notaram que a PCG não mostrou o efeito da redução de temperatura na compacidade (ou na 
habilidade de densificar) das misturas asfálticas, enquanto o compactador Marshall foi capaz de fazê-lo.

De modo semelhante, Huner e Brown (2001) estudaram o efeito da variação de temperatura nas propriedades volumétricas de misturas asfálticas em compactador giratório e não observaram diferenças significativas quando a temperatura foi diminuída ou aumentada em $14^{\circ} \mathrm{C}$ em relação àquela indicada para a compactação.

\subsubsection{Comparativo: Compactação}

Para melhor visualização de como são as tendências em cada tipo de ensaio de compactação realizado com as misturas estudadas, a Figura 52 apresenta em um único gráfico os valores médios obtidos com compactação Marshall, em mesa compactadora e em PCG (após 200 giros, ao final do ensaio).

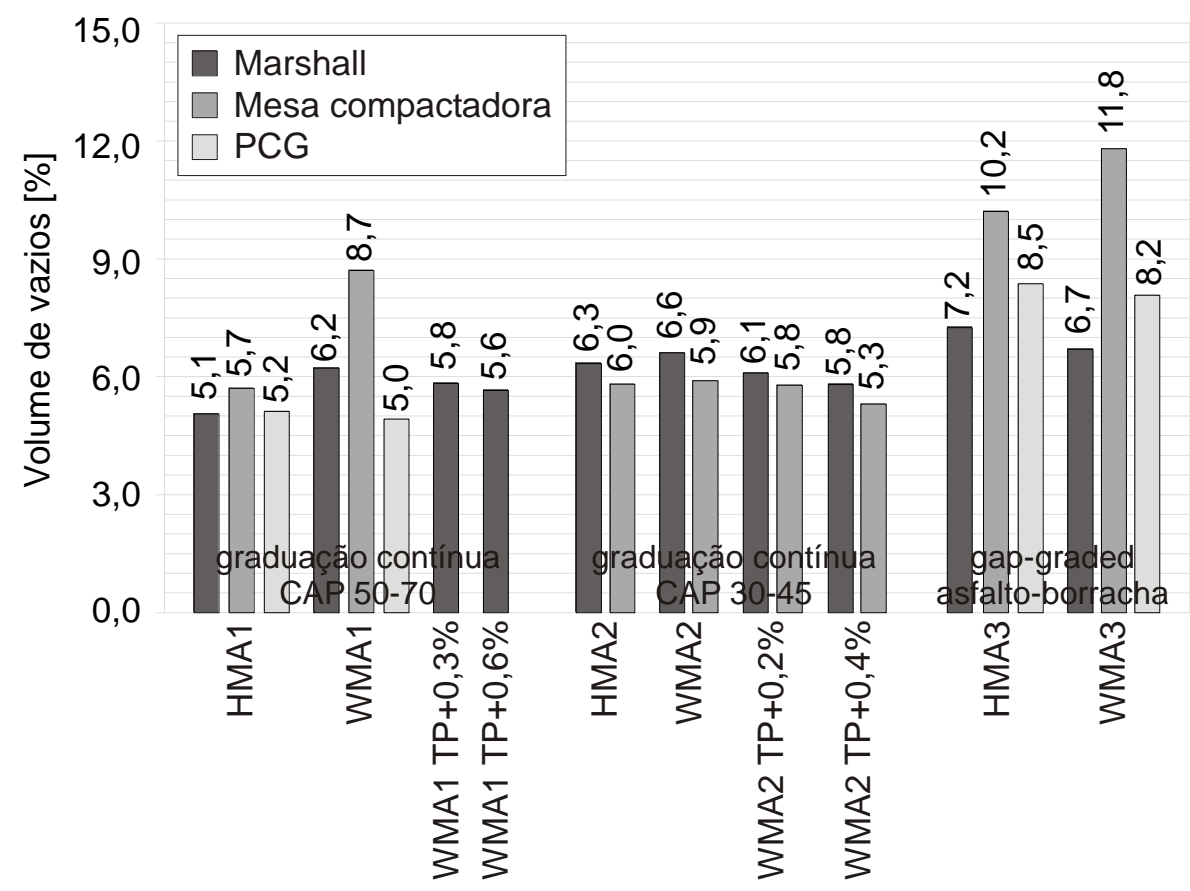

Figura 52 - Resumo de resultados de compactação em equipamentos Marshall, mesa compactadora e prensa de cisalhamento giratório

No caso das misturas 1, verifica-se que a densificação Marshall (por impacto) parece ser mais enérgica, impondo menores valores de $V V$ do que na compactação em mesa compactadora e em PCG, mesmo estas misturas tendo sido consideradas 
com baixa quantidade de asfalto, o que ficou evidenciado no ensaio da PCG. Particularmente na situação da WMA1, o processo de rolagem mostrou a dificuldade de densificação desta mistura não só pela falta de ligante, mas também pela temperatura significativamente baixa de compactação.

Já na situação das misturas 2, a densificação feita pelo método Marshall e pela mesa compactadora não apresentou diferenças expressivas entre si, devendose considerar neste caso que o teor de asfalto e a temperatura de compactação tenham sido considerados adequados às misturas mornas deste tipo.

Por fim, o processo de densificação das misturas 3 mostrou-se particularmente mais difícil nas situações de rolagem e de prensa giratória que no ensaio Marshall, acreditando-se que isto se deva ao tipo de granulometria (semidescontínua) somada à viscosidade do ligante empregado em tais níveis elevados de temperatura. Como já comentado anteriormente, alguns testes recentes no LTP/EPUSP com misturas asfálticas deste tipo têm demonstrado que a sua compactação por rolagem em mesa compactadora deve ser realizada em temperaturas mais baixas para ser mais eficiente e apresentar menor VV.

\subsubsection{Resistência à tração}

O ensaio para determinação da RT foi realizado conforme descrito no item 3.5.2. A Figura 53 apresenta os valores médios de RT, bem como o VV médio dos CPs testados. Em seguida, a Tabela 20 e a Tabela 21 apontam, respectivamente, os resultados da análise de variância da RT e do VV. 


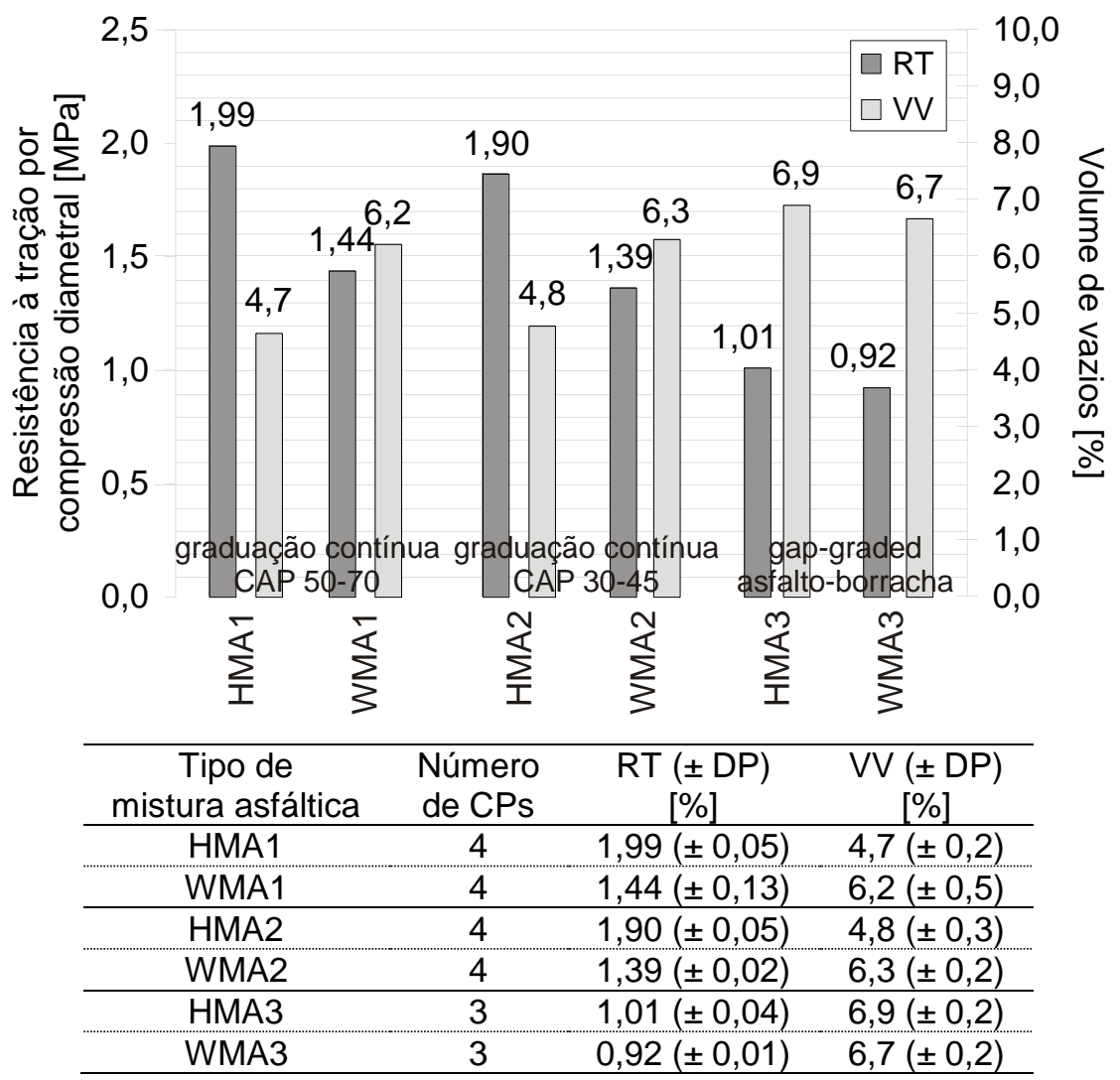

Figura 53 - Resultados de resistência à tração

Tabela 20 - Análise de variância da resistência à tração

\begin{tabular}{cccc}
\hline Tipo de mistura asfáltica & HMA1 & HMA2 & HMA3 \\
\hline WMA1 & ED & -- & -- \\
\hline WMA2 & -- & ED & -- \\
\hline WMA3 & -- & -- & El \\
\hline
\end{tabular}

Tabela 21 - Análise de variância do volume de vazios na resistência à tração

\begin{tabular}{cccc}
\hline Tipo de mistura asfáltica & HMA1 & HMA2 & HMA3 \\
\hline WMA1 & ED & -- & -- \\
\hline WMA2 & -- & ED & -- \\
\hline WMA3 & -- & -- & El \\
\hline
\end{tabular}

Nota-se que a WMA1 apresentou menor RT que a HMA1, devido ao seu maior VV, decorrente da condição de baixo teor de ligante e de grande redução de temperatura de usinagem e compactação.

Já no caso da HMA2 e da WMA2, acredita-se que houve algum problema de variação de temperatura durante a preparação dos corpos de prova para o ensaio, que ocasionou tal diferença de VV e levou a HMA2 a apresentar maior valor de RT que a WMA2. 
$\mathrm{Na}$ situação da WMA3, observa-se que sua RT foi considerada estatisticamente igual à da $\mathrm{HMA} 3$, em uma condição de vazios também iguais.

De qualquer maneira, confrontando-se os resultados obtidos com os limites especificados pelo DNIT, em que as misturas 1 e 2 deveriam atingir pelo menos 0,65 $\mathrm{MPa}$ e a mistura 3 no mínimo 0,50 MPa, conclui-se que todas as misturas mornas atenderam tais especificações, mesmo a WMA1 e a WMA2 que apresentaram uma RT significativamente mais baixa que a HMA1 e a HMA2, respectivamente.

Por fim, cabe mencionar que se esperava que as misturas asfálticas com CAP 30-45 mostrassem uma RT mais alta que aquela com CAP 50-70, devido à maior consistência do ligante. Todavia, o comportamento foi muito semelhante, acreditando-se que isto se deva ao fato de que este CAP 50-70 possua penetração, ponto de amolecimento e viscosidade próximos do limite mínimo na especificação brasileira para que fosse considerado um CAP 30-45 (como mostrado anteriormente na Tabela 11).

\subsubsection{Módulo de resiliência}

O ensaio para determinação do MR foi realizado conforme descrito no item 3.5.3. A Figura 54 apresenta os valores médios de MR, bem como o VV médio dos CPs testados. Em seguida, a Tabela 22 e a Tabela 23 apontam, respectivamente, os resultados da análise de variância do MR e do VV. 


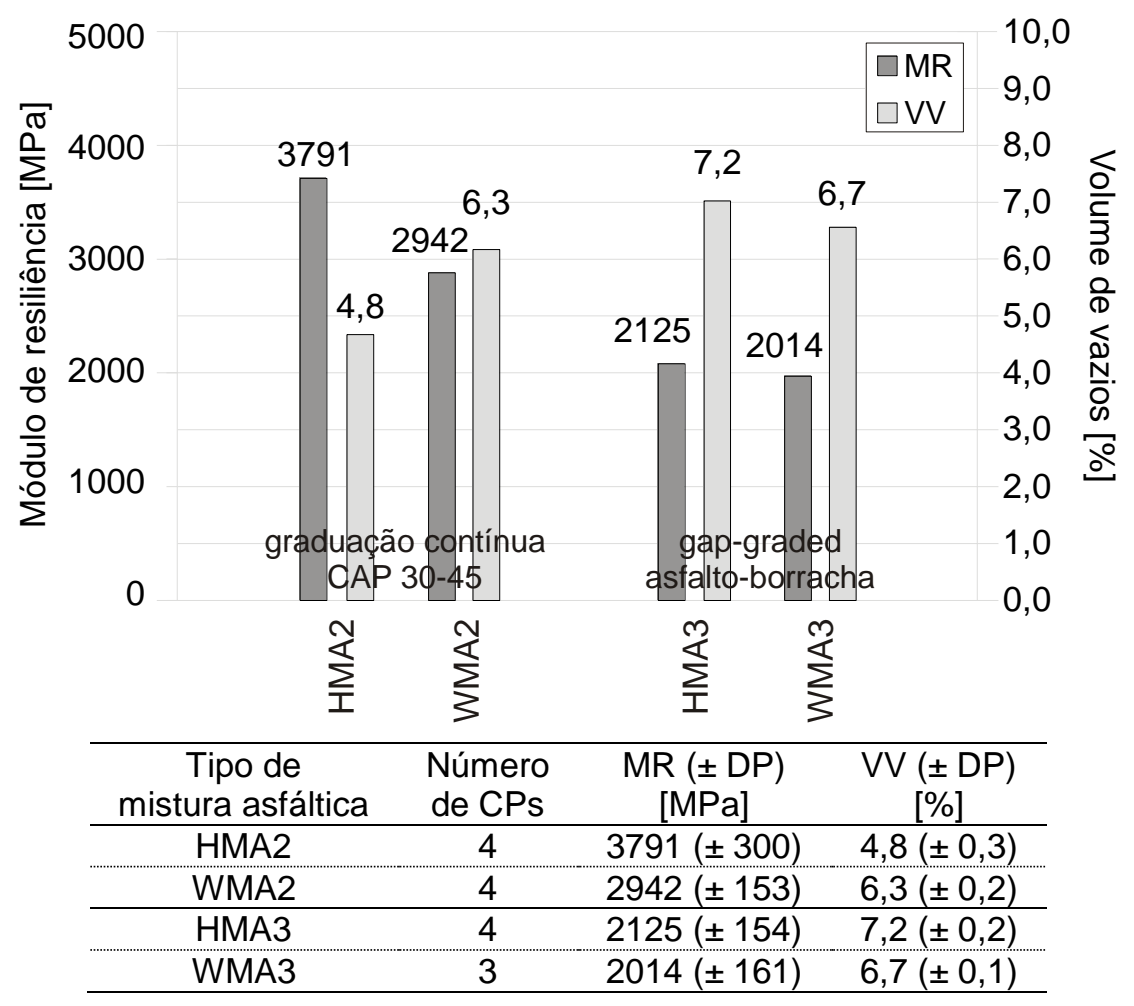

Figura 54 - Resultados de módulo de resiliência

Tabela 22 - Análise de variância do módulo de resiliência

\begin{tabular}{ccc}
\hline Tipo de mistura asfáltica & HMA2 & HMA3 \\
\hline WMA2 & ED & -- \\
\hline WMA3 & -- & El \\
\hline
\end{tabular}

Tabela 23 - Análise de variância do volume de vazios no módulo de resiliência

\begin{tabular}{ccc}
\hline Tipo de mistura asfáltica & HMA2 & HMA3 \\
\hline WMA2 & ED & -- \\
\hline WMA3 & -- & ED \\
\hline
\end{tabular}

Conforme já comentado no item anterior sobre RT, deve ter ocorrido algum problema de variação de temperatura na preparação dos corpos de prova da HMA2 e da WMA2, levando a valores de VV muito diferentes. Com isto, o resultado de MR da WMA2 se mostrou significativamente inferior ao da mistura de referência, mas isto se deve à grande diferença de VV.

Já no caso da WMA3, o MR foi considerado estatisticamente igual ao da HMA3, embora os valores de VV fossem estatisticamente diferentes. Assim, do mesmo modo que foi comentado no item 3.5.1.1, ainda que os vazios não tenham sido tidos como iguais, entende-se que tal diferença seja pequena, não tendo influência significativa na propriedade mecânica de MR. 
Além disso, verifica-se ainda que o $M R$ entre as misturas convencionais e misturas mornas seguiu a mesma tendência da RT, com maior diferença entre as misturas 2 e menor variação entre as misturas 3. A propósito, Bernucci et al. (2008) mencionam que há uma boa correlação entre módulo de resiliência e resistência à tração dentro de cada "família" de misturas asfálticas (considerando composição granulométrica e tipo de ligante), cuja relação inclusive permanece constante com o passar do tempo (com o envelhecimento).

De qualquer modo, os resultados de MR encontrados nesta pesquisa estão dentre os valores considerados típicos por Bernucci et al. (2008), usualmente entre 2.000 e $8.000 \mathrm{MPa}$ (onde os maiores MR corresponderiam a misturas com asfaltos extremamente duros).

Um aspecto importante a se notar é que as misturas 3 alcançaram menores valores de MR que as misturas 2, mas isto não significa que seu comportamento seja inferior. Em geral, observam-se valores mais baixos de MR quando há o uso de ligantes modificados (com borracha, por exemplo), pois estes materiais conferem elasticidade à mistura asfáltica, que por sua vez "deforma-se" mais quando recebe a aplicação de carga (neste caso a $25^{\circ} \mathrm{C}$ ).

\subsubsection{Deformação permanente}

O ensaio de deformação permanente foi realizado segundo descrito no item 3.5.4. Como cada placa requer um volume significativo de material, foram moldados um a dois CPs em cada situação. A Figura 55 apresenta a evolução da deformação permanente, em forma de porcentagem de afundamento em trilha de roda, entre 100 e 30.000 ciclos de cada mistura estudada, sendo que nos casos em haviam dois CPs o valor representa a média de ambos. 


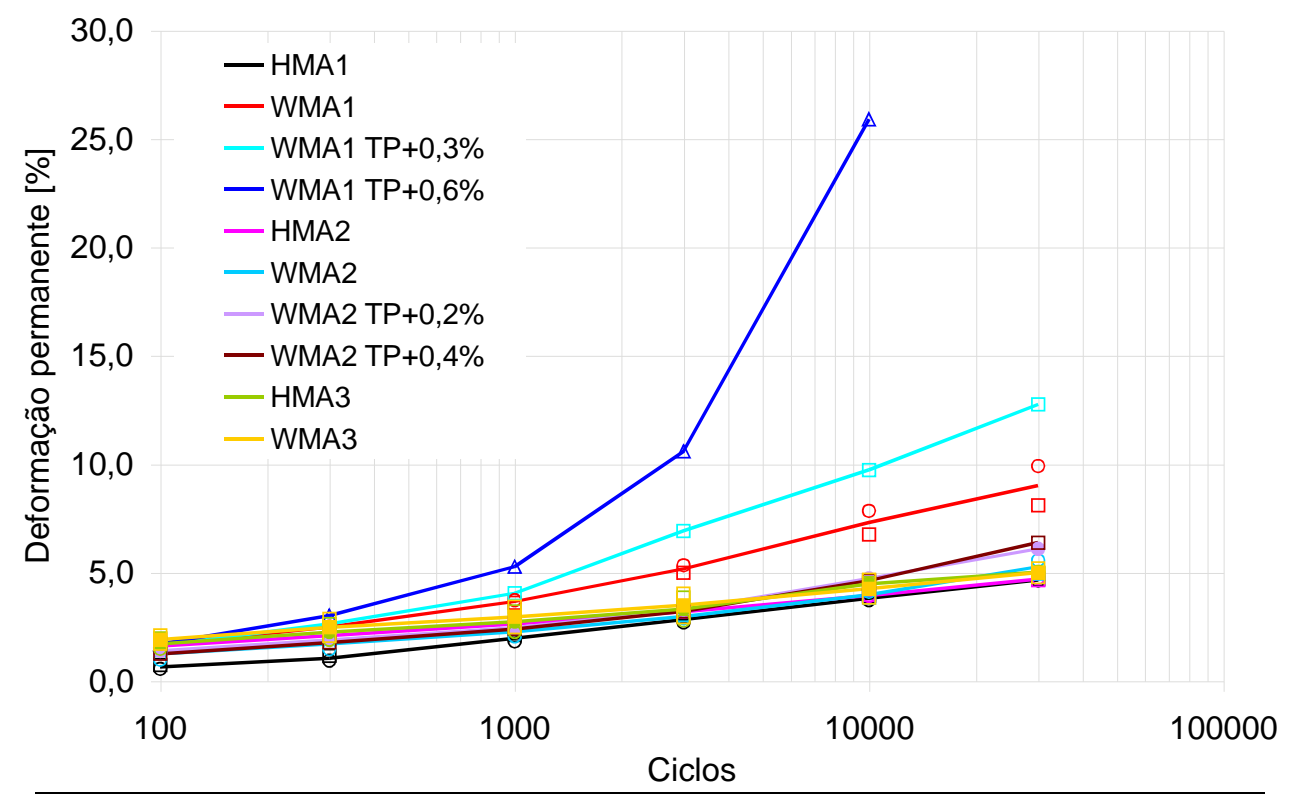

\begin{tabular}{|c|c|c|c|c|c|c|c|}
\hline \multirow{3}{*}{$\begin{array}{c}\text { Tipo de } \\
\text { mistura asfáltica }\end{array}$} & \multirow{3}{*}{$\begin{array}{l}\text { Número } \\
\text { de CPs }\end{array}$} & \multicolumn{6}{|c|}{ Ciclos } \\
\hline & & 100 & 300 & 1000 & 3000 & 10000 & 30000 \\
\hline & & \multicolumn{6}{|c|}{ Afundamento em trilha de roda [\%] } \\
\hline HMA1 & 2 & 0,6 & 1,0 & 2,0 & 2,8 & 3,8 & 4,7 \\
\hline WMA1 & 2 & 1,7 & 2,5 & 3,7 & 5,2 & 7,3 & 9,0 \\
\hline WMA1 TP+0,3\% & 1 & 1,6 & 2,6 & 4,0 & 6,9 & 9,7 & 12,8 \\
\hline WMA1 TP+0,6\% & 1 & 1,7 & 3,0 & 5,3 & 10,6 & 25,9 & * \\
\hline HMA2 & 2 & 1,6 & 2,1 & 2,6 & 3,2 & 3,9 & 4,7 \\
\hline WMA2 & 2 & 1,3 & 1,7 & 2,3 & 3,0 & 4,0 & 5,3 \\
\hline WMA2 TP+0,2\% & 1 & 1,4 & 1,9 & 2,4 & 3,3 & 4,7 & 6,1 \\
\hline WMA2 TP+0,4\% & 1 & 1,3 & 1,8 & 2,4 & 3,2 & 4,6 & 6,4 \\
\hline HMA3 & 2 & 1,7 & 2,3 & 2,7 & 3,3 & 4,5 & 5,0 \\
\hline WMA3 & 2 & 1,9 & 2,5 & 3,0 & 3,5 & 4,3 & 5,0 \\
\hline
\end{tabular}

* O ensaio foi interrompido aos 10.000 ciclos, pois a deformação permanente já havia ocorrido em demasia

Figura 55 - Resultados de deformação permanente em trilha de roda

É possível observar que, no teor de projeto, a WMA1 foi muito suscetível à deformação permanente, pois sofreu quase o dobro de afundamento em relação à HMA1. Acredita-se que isto se deva ao baixo teor de ligante de projeto $(4,4 \%)$, associado à grande redução de temperatura de usinagem e compactação, levando a WMA1 a um processo de pós-compactação durante o ensaio (provavelmente ainda favorecido pela condição de teste a $60^{\circ} \mathrm{C}$ ).

Já a WMA2 apresentou deformação ligeiramente maior que a HMA2, cuja diferença não foi tão notável como no caso da WMA1, já que o aumento de afundamento da WMA2 em relação à HMA2 foi somente de $0,6 \%$. Neste caso, podese considerar que ambas tiveram comportamento similar à deformação permanente. 
Por fim, a WMA3 apresentou comportamento muito semelhante ao da HMA3, onde, inclusive, os valores de deformação permanente final foram exatamente iguais.

Observa-se ainda que com o incremento da consistência do ligante (CAP 5070 < CAP 30-45 < asfalto-borracha), também há uma elevação da quantidade de asfalto requerida no projeto das misturas $(4,4 \%<5,0 \%<6,5 \%)$, mas não do potencial à deformação permanente.

Tendo-se em vista que as especificações francesas e europeias recomendam que o afundamento de misturas BBSG 3 0/14 (para tráfego pesado) deva ser até 5\% após 30.000 ciclos (caso das misturas 1 e 2), e de misturas BBTM 10B deva ser inferior a $15 \%$ após 3.000 ciclos (caso das misturas 3 ) no simulador, observa-se que a WMA1 se situou expressivamente fora do limite francês, a WMA2 o ultrapassou ligeiramente, enquanto a WMA3 atendeu a norma europeia.

$\mathrm{Na}$ verdade, como no Brasil tem-se aconselhado que a deformação permanente máxima fique em torno de $5 \%$, devido às condições severas de tráfego e de temperatura, tanto a WMA2 quanto a WMA3 tiveram afundamentos em trilha de roda considerados aceitáveis após os 30.000 ciclos, perante tal recomendação.

No item 3.5.1, mencionou-se que as misturas 1 e 2 foram preparadas com teores de ligante acima daquele de projeto para observar se isto melhoraria a compactação, mas que esta ação poderia levar a um aumento do potencial à deformação permanente, devendo este aspecto ser verificado. Dentro deste contexto, notou-se que o acréscimo da quantidade de ligante acima do tolerável em usina teve impacto muito negativo no caso da WMA1 (com seu afundamento chegando a níveis muito elevados e o ensaio tendo que ser finalizado antes dos 30.000 ciclos), diferentemente da situação da WMA2 em que o potencial à deformação permanente também aumentou, mas não de modo tão significativo. De qualquer maneira, o uso de mistura morna com quantidade de ligante igual ao teor de projeto da mistura a quente se mostrou ser o mais adequado.

\subsubsection{Dano por umidade induzida}

O ensaio de dano por umidade induzida foi realizado segundo descrito no item 3.5.5 e a Tabela 24 apresenta os resultados médios obtidos, bem como o 
número de CPs empregados em cada caso (metade na situação de condicionamento à água e a outra metade como referência). Em seguida, têm-se os resultados de análise de variância dos parâmetros de RT e VV na Tabela 25.

Tabela 24 - Resultados do ensaio de dano por umidade induzida

\begin{tabular}{|c|c|c|c|c|c|c|}
\hline & HMA1 & WMA1 & HMA2 & $\begin{array}{c}\text { WMA2 } \\
\text { TP+0,4\%* }\end{array}$ & HMA3 & WMA3 \\
\hline Número de CPs & 10 & 6 & 8 & 8 & 8 & 6 \\
\hline RTnc ( \pm DP) [MPa] & $1,60( \pm 0,19)$ & $1,54( \pm 0,04)$ & $1,65( \pm 0,03)$ & $1,18( \pm 0,14)$ & $1,15( \pm 0,04)$ & $1,00( \pm 0,06)$ \\
\hline $\operatorname{VVnc}( \pm \mathrm{DP})[\%]$ & $6,4( \pm 0,2)$ & $6,2( \pm 0,1)$ & $6,4( \pm 0,2)$ & $6,9( \pm 0,6)$ & $7,6( \pm 0,1)$ & $7,7(0)$ \\
\hline RTc $( \pm$ DP $)[\mathrm{MPa}]$ & $0,99( \pm 0,18)$ & $1,05( \pm 0,03)$ & $1,49( \pm 0,08)$ & $1,05( \pm 0,04)$ & $1,01( \pm 0,04)$ & $0,82( \pm 0,05)$ \\
\hline VVc $( \pm \mathrm{DP})[\%]$ & $7,5( \pm 0,5)$ & $6,4( \pm 0,1)$ & $6,9( \pm 0,3)$ & $6,5( \pm 0,3)$ & $7,7( \pm 0,1)$ & $7,9(0)$ \\
\hline RRT & 0,62 & 0,69 & 0,90 & 0,89 & 0,88 & 0,82 \\
\hline
\end{tabular}

* Conforme mencionado anteriormente, a mistura morna 2 foi testada somente no teor de ligante que foi indicado no projeto de dosagem do trecho experimental da Rodovia Presidente Dutra (item 4.1.2)

Onde:

$\mathrm{RTnc}=$ Resistência à tração média dos CPs não condicionados à água;

$V V n c=$ Volume de vazios dos CPs não condicionados à água;

$\mathrm{RTC}=$ Resistência à tração média dos CPs condicionados à água;

$\mathrm{VVc}=$ Volume de vazios dos CPs condicionados à água;

$\mathrm{RRT}=$ Resistência retida à tração.

Tabela 25 - Análise de variância da resistência à tração e volume de vazios no ensaio de dano por umidade induzida

\begin{tabular}{|c|c|c|c|c|c|c|c|c|c|c|c|c|c|}
\hline \multirow{2}{*}{$\begin{array}{l}\text { Tipo de } \\
\text { mistura } \\
\text { asfáltica }\end{array}$} & \multirow[b]{2}{*}{ Parâm. } & \multicolumn{4}{|c|}{ HMA1 } & \multicolumn{4}{|c|}{ HMA2 } & \multicolumn{4}{|c|}{ HMA3 } \\
\hline & & RTnc & VVnc & RTc & VVc & RTnc & VVnc & RTc & VVc & RTnc & VVnc & RTc & VVc \\
\hline \multirow{4}{*}{ WMA1 } & RTnc & $\mathrm{EI}$ & -- & -- & -- & -- & -- & $\overline{--}$ & $\overline{--}$ & $\overline{--}$ & -- & $\overline{--}$ & -- \\
\hline & VVnc & -- & $\mathrm{El}$ & -- & -- & -- & -- & -- & -- & -- & -- & -- & -- \\
\hline & RTc & -- & -- & $\mathrm{EI}$ & -- & -- & -- & -- & -- & -- & -- & -- & -- \\
\hline & VVc & -- & - & -- & ED & -- & -- & - & -- & -- & -- & -- & -- \\
\hline \multirow{4}{*}{$\begin{array}{c}\text { WMA2 } \\
\text { TP+0,4\% }\end{array}$} & RTnc & -- & -- & -- & -- & ED & -- & -- & -- & -- & -- & -- & -- \\
\hline & VVnc & -- & -- & -- & -- & -- & $\mathrm{El}$ & -- & -- & -- & -- & -- & -- \\
\hline & RTc & -- & -- & -- & -- & -- & -- & ED & -- & -- & -- & -- & -- \\
\hline & $V_{V c}$ & -- & -- & -- & -- & -- & -- & -- & $\mathrm{El}$ & -- & -- & -- & -- \\
\hline \multirow{4}{*}{ WMA3 } & RTnc & -- & -- & -- & -- & -- & -- & -- & -- & ED & -- & -- & -- \\
\hline & VVnc & -- & -- & -- & -- & -- & -- & -- & -- & -- & ED & -- & -- \\
\hline & $\mathrm{RTc}$ & -- & -- & -- & -- & -- & -- & -- & -- & -- & -- & ED & -- \\
\hline & VVc & -- & -- & -- & -- & -- & -- & -- & -- & -- & -- & -- & ED \\
\hline
\end{tabular}

Um fato interessante observado é que mesmo com a maior porcentagem de vazios exigida para este ensaio, todas as misturas apresentaram valores médios de RT bastante acima dos limites mínimos exigidos nas normas DNIT ES031/06 e ES112/09, respectivamente 0,65 MPa (caso das misturas 1 e 2) e 0,50 MPa (caso das misturas 3). 
Considerando-se que a RRT mínima requerida pelas normas DNIT ES031/06 e ES112/09 é 0,7, verifica-se que somente a HMA1 não atendeu tal exigência, embora contivesse $1,5 \%$ de cal (que age como melhorador de adesividade). $O$ fato é que a HMA1 era uma mistura que vinha sendo pesquisada em nível laboratorial e, caso houvesse a intenção de empregá-la em pista, procurar-se-ia fazer alterações relativas à quantidade de cal (aumento desta), buscando melhorar a adesividade.

No geral, pode-se dizer que as misturas mornas tiveram boa resistência ao dano por umidade induzida, dentro do recomendável, além de terem apresentado comportamento semelhante à de suas misturas a quente de referência (exceto WMA1, cuja resistência foi ligeiramente maior que a da HMA1). 


\section{TRECHOS EXPERIMENTAIS}

\subsection{TRECHO EXPERIMENTAL COM MISTURA MORNA NA RODOVIA PRESIDENTE DUTRA}

O primeiro trecho experimental com mistura morna acompanhado nesta pesquisa foi realizado na Rodovia Presidente Dutra. Esta é a principal rodovia do país, e liga as regiões metropolitanas de São Paulo e Rio de Janeiro em uma extensão de 402 quilômetros. Foi inaugurada em janeiro de 1951, com apenas uma pista e duas faixas de rolamento e, até meados da década de 60 , possuía uma grande capacidade de escoamento do tráfego, mas com o aumento da frota nacional e do volume de transporte de cargas ficou saturada com menos de 15 anos de uso. Em decorrência disto, entre 1965 e 1967 a Dutra foi duplicada e recebeu melhoramentos nas décadas seguintes, e em 1996 passou a ter sua operação concedida à concessionária NovaDutra ${ }^{11}$.

O trecho experimental em questão foi inserido dentro de uma programação de intervenções que vêm sendo realizadas pela concessionária, tendo sido executado no km 225, na altura da cidade de Guarulhos (Grande São Paulo), distante cerca de $17 \mathrm{~km}$ do centro da cidade São Paulo (Figura 56). A mistura morna foi aplicada na pista expressa sul (sentido São Paulo), na faixa 1 (veículos leves). Cabe mencionar que esta foi a primeira intervenção naquele local, desde que a concessionária assumiu a operação da rodovia (segundo informações da NovaDutra).

\footnotetext{
${ }^{11}$ Informações disponíveis em <http://www.novadutra.com.br>. Acesso em 18 mar. 2010.
} 


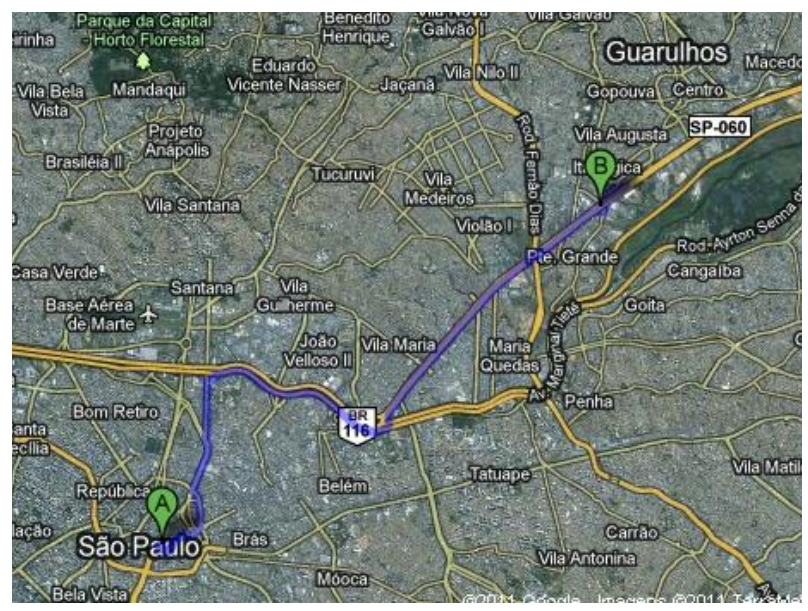

Figura 56 - Localização do trecho experimental na Rodovia Presidente Dutra em Guarulhos, em relação a São Paulo retirado de www.maps.google.com

Segundo informações da concessionária, o pavimento onde foi aplicado o segmento de mistura morna possui uma camada asfáltica de $20 \mathrm{~cm}$ e uma sub-base de $35 \mathrm{~cm}$ e, à época do projeto de restauração, estava submetido a um Volume Diário Médio (VDM) de veículos comerciais de 5.094, com número N (10 anos) de $1,65 \times 10^{8}$, classificando esta rodovia como sendo de tráfego muito pesado.

\subsubsection{Condição inicial do pavimento}

Antes da execução do trecho experimental, a concessionária NovaDutra realizou levantamentos das condições superficiais, estruturais e funcionais do pavimento.

\subsubsection{Defeitos}

No local onde seria executado o trecho experimental, o levantamento de defeitos de superfície apontou basicamente a existência de trincas longitudinais e transversais longas na faixa $1^{12}$ (fissuras), em uma extensão de quase $650 \mathrm{~m}$, totalizando uma área de $2250 \mathrm{~m}^{2}$, entre os $\mathrm{km} 225+250$ e $225+900$. A Figura 57 ilustra em forma de croqui a área de concentração das trincas na faixa 1, bem como a posição de drenos transversais e a existência de uma obra de arte no local.

\footnotetext{
${ }^{12}$ Os defeitos referentes à faixa 2 não são apresentados aqui, já que não correspondem ao local de aplicação da mistura morna.
} 


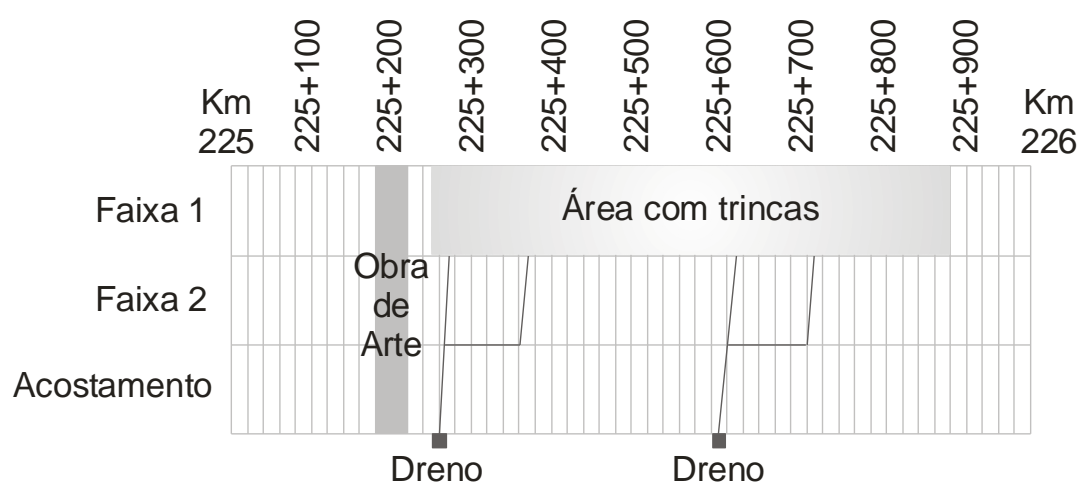

Figura 57 - Croqui da região onde seria executado o trecho experimental na Rodovia Presidente Dutra

\subsubsection{Deflexões}

Já a avaliação da condição estrutural foi feita com base no levantamento de deflexões com o equipamento Falling Weight Deflectometer (FWD) - ilustrado na Figura 58 - com carga de 4,1 t aplicada no $D_{0}$. Os resultados são apresentados na Figura 59, onde observa-se que, no geral, as deflexões eram baixas, mas haviam alguns pontos com valores próximos ao da deflexão máxima admissível calculada $\left(41,3 \times 10^{-2} \mathrm{~mm}\right)$. Cabe salientar que os maiores picos se encontram justamente nos locais onde têm-se os drenos (indicados na Figura 57).

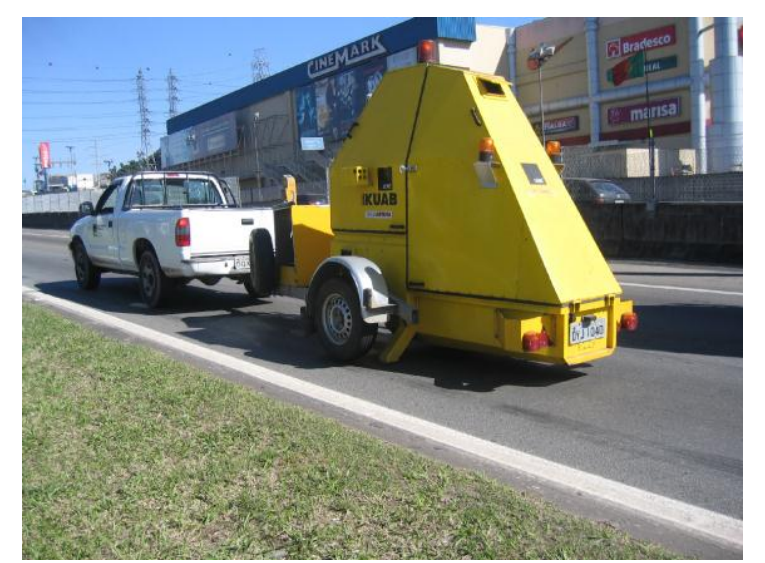

Figura 58 - Levantamento de deflexões com FWD 


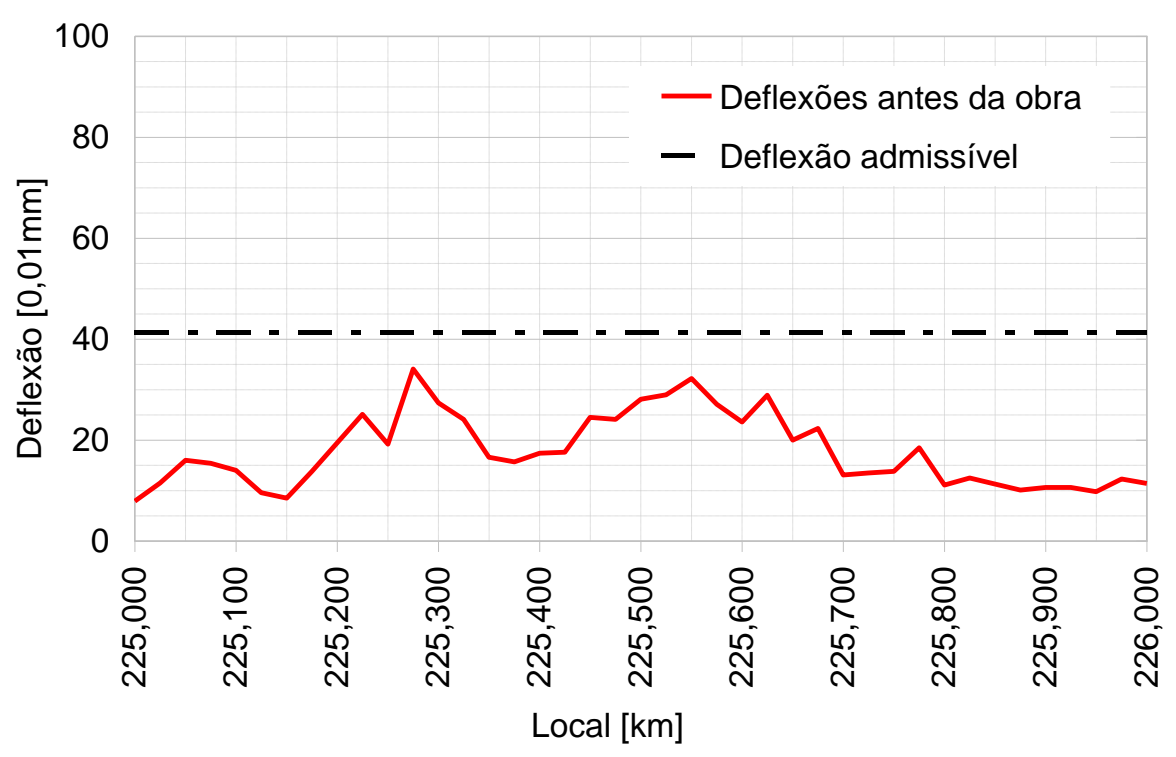

Figura 59 - Resultados de deflexões com FWD antes da obra

De acordo com Bernucci et al. (2007), a ordem de grandeza das deflexões dos pavimentos asfálticos varia muito com as características da estrutura, o tipo de revestimento, o nível de trincamento, as condições climáticas etc., mas como valor típico poder-se-ia indicar de 30 a $50 \times 10^{-2} \mathrm{~mm}$ para um pavimento com revestimento de concreto asfáltico e base granular em boa condição estrutural. Considerando-se então estes números, verifica-se que as deflexões na Rodovia Presidente Dutra são de fato baixas.

\subsubsection{Irregularidade longitudinal}

Por fim, a condição funcional foi determinada com perfilômetro laser ilustrado na Figura 60 - para determinação da irregularidade longitudinal através dos índices QI (Quociente de Irregularidade) e IRI (International Roughness Index). 


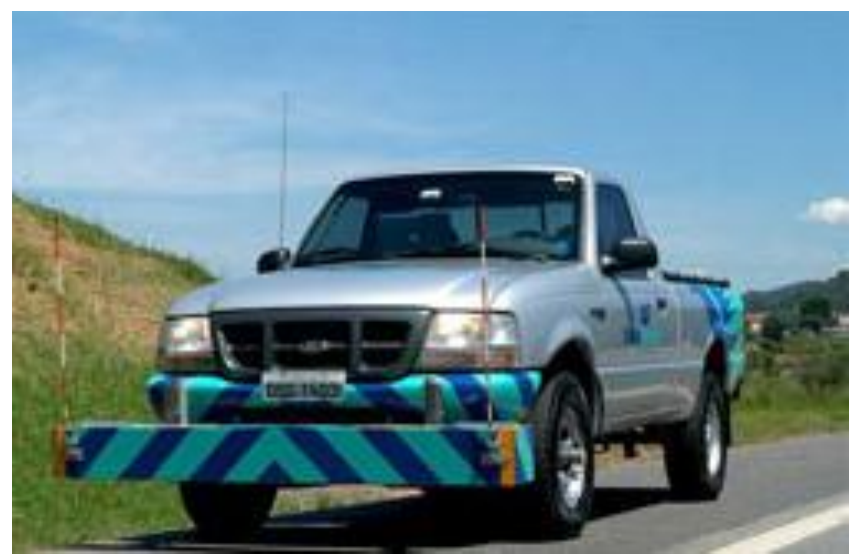

Figura 60 - Levantamento de irregularidade com perfilômetro laser retirado de www.dynatest.com.br

O Manual de Restauração de Pavimentos Asfálticos do DNIT (2006) classifica a condição do pavimento conforme o valor de tais índices de irregularidade, segundo apontado na Tabela 31, sendo estes os indicadores usualmente empregados por órgãos de fiscalização como a ANTT e a ARTESP (Agência de Transporte do Estado de São Paulo).

Tabela 26 - Classificação da irregularidade longitudinal em função do QI e do IRI

\begin{tabular}{ccc}
\hline Conceito & \multicolumn{2}{c}{ Irregularidade } \\
& QI [cont/km] & IRI [m/km] \\
\hline Excelente & 13 a 25 & 1 a 1,9 \\
\hline Bom & 25 a 35 & 1,9 a 2,7 \\
\hline Regular & 35 a 45 & 2,7 a 3,5 \\
\hline Ruim & 45 a 60 & 3,5 a 4,6 \\
\hline Péssimo & $>60$ & $>4,6$
\end{tabular}

Para esta pesquisa os levantamentos foram feitos a cada $100 \mathrm{~m}$, com o veículo operando a cerca de $100 \mathrm{~km} / \mathrm{h}$. Os resultados são indicados na Figura 61, juntamente com os valores recomendáveis apontados na Tabela 26. Nota-se que grande parte do segmento apresentava irregularidade elevada, com pontos acima dos níveis de QI e IRI aceitáveis. 


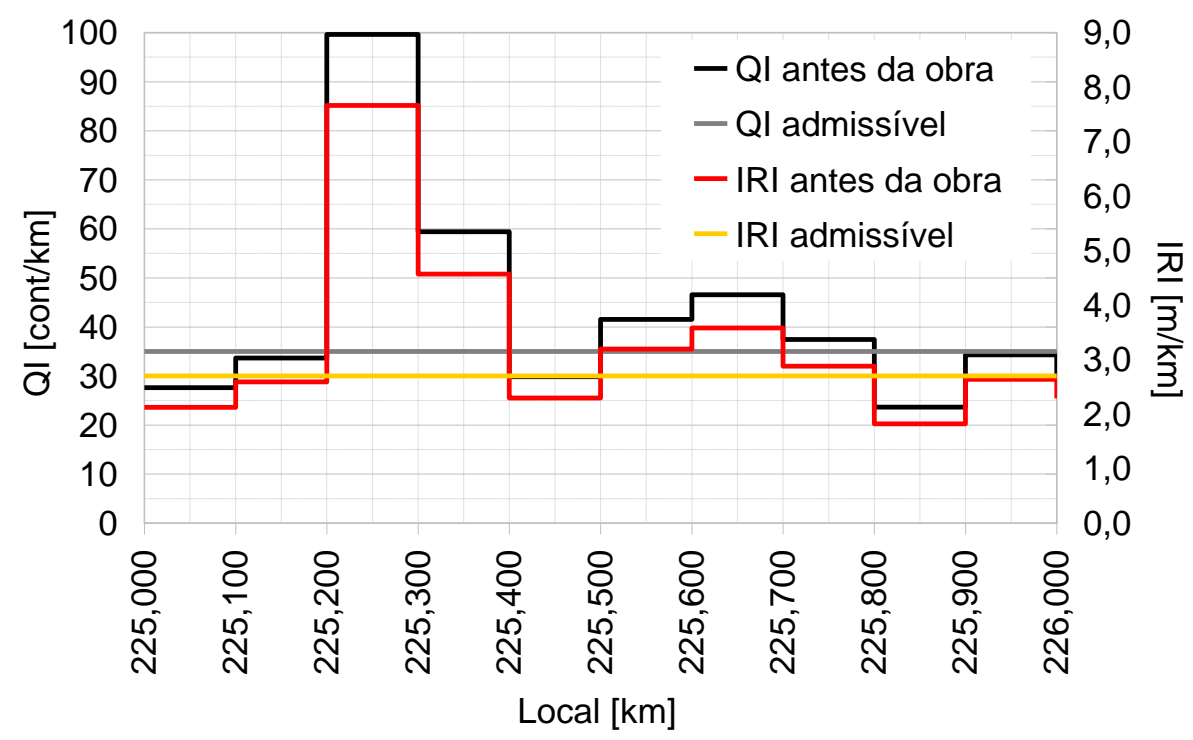

Figura 61 - Resultados de QI e IRI antes da obra

Por conta dos resultados obtidos nos levantamentos de defeitos de superfície e de condições funcionais, foi indicada uma intervenção no trecho em questão, com fresagem de $6 \mathrm{~cm}$ e recomposição com mistura asfáltica, entre o km 225+250 e o 225+900. Dentro deste projeto, a pavimentação com mistura morna seria realizada entre o km 225+250 e o $225+600$.

\subsubsection{Projeto da mistura morna}

A princípio, a mistura morna indicada para aplicação no segmento-teste da Rodovia Presidente Dutra seria a WMA2. Entretanto, em se tratando de uma primeira experiência e receando-se dificuldades de compactação em campo por falta de lubrificação, apontou-se a WMA2 TP+0,4\% como a mistura morna a ser empregada no trecho experimental.

De maneira resumida, a Tabela 27 apresenta o traço e as temperaturas indicados à usina de asfalto, para o preparo da mistura morna. Além disso, recomendou-se que o Gemul XT14 fosse introduzido no tanque de ligante e mantido sob agitação até o momento de uso do asfalto. 
Tabela 27 - Traço e temperaturas indicados para a produção da mistura morna do trecho experimental da Rodovia Presidente Dutra

\begin{tabular}{|c|c|c|c|c|c|c|c|}
\hline \multicolumn{2}{|c|}{ Ligante asfáltico CAP 30-45 } & \multicolumn{6}{|c|}{ Teor em peso adicionado: $5,4 \%$} \\
\hline \multirow{4}{*}{$\begin{array}{c}\text { Agregados } \\
{[\%]}\end{array}$} & Brita 1 & \multicolumn{6}{|c|}{14,0} \\
\hline & Pedrisco & \multicolumn{6}{|c|}{45,0} \\
\hline & Pó-de-pedra & \multicolumn{6}{|c|}{39,5} \\
\hline & $\mathrm{Cal} \mathrm{CH}-\mathrm{I}$ & \multicolumn{6}{|c|}{1,5} \\
\hline \multicolumn{2}{|c|}{ Aditivo Gemul XT14 } & \multicolumn{6}{|c|}{ Teor em peso de asfalto: $0,3 \%$} \\
\hline \multirow{4}{*}{$\begin{array}{c}\text { Temperatura } \\
{\left[{ }^{\circ} \mathrm{C}\right]}\end{array}$} & Ligante & \multirow{4}{*}{ } & 156 & \multirow{4}{*}{ 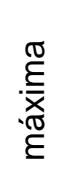 } & 163 & \multirow{4}{*}{$\begin{array}{l}\stackrel{\frac{\pi}{\sigma}}{0} \\
\stackrel{\oplus}{\varepsilon}\end{array}$} & 159 \\
\hline & Agregados & & 131 & & 138 & & 134 \\
\hline & Usinagem & & 131 & & 138 & & 134 \\
\hline & Compactação & & 120 & & 125 & & 122 \\
\hline
\end{tabular}

\subsubsection{Produção em usina e aplicação da mistura morna em pista}

A obra do trecho experimental foi feita durante a madrugada do dia 12 de novembro de 2009 (as obras na Rodovia Presidente Dutra são sempre noturnas, devido ao seu tráfego muito elevado), após uma fresagem de $6 \mathrm{~cm}$, seguindo do $\mathrm{km}$ $225+250$ até o 225+600 e totalizando pouco mais de $300 \mathrm{~m}$ naquela noite.

A mistura morna foi preparada na usina de asfalto da Serveng Barueri (que é do tipo gravimétrica), tendo sido executada do mesmo modo que uma mistura convencional, com exceção da temperatura. A usinagem pôde ser efetuada a $135^{\circ} \mathrm{C}$ e, ao final, os agregados aparentavam estar bem envolvidos pelo ligante.

Para a pista foram expedidos oito caminhões de massa asfáltica morna e, além disso, uma parte do material usinado foi enviada ao LTP/EPUSP para ensaios posteriores.

Da Figura 62 à Figura 64 têm-se algumas fotos da execução do trecho experimental com a mistura morna na Rodovia Presidente Dutra. Cabe mencionar que a temperatura do material no momento da compactação era de $120^{\circ} \mathrm{C}$ e a temperatura ambiente era de cerca de 15 a $20^{\circ} \mathrm{C}$ em pista. 


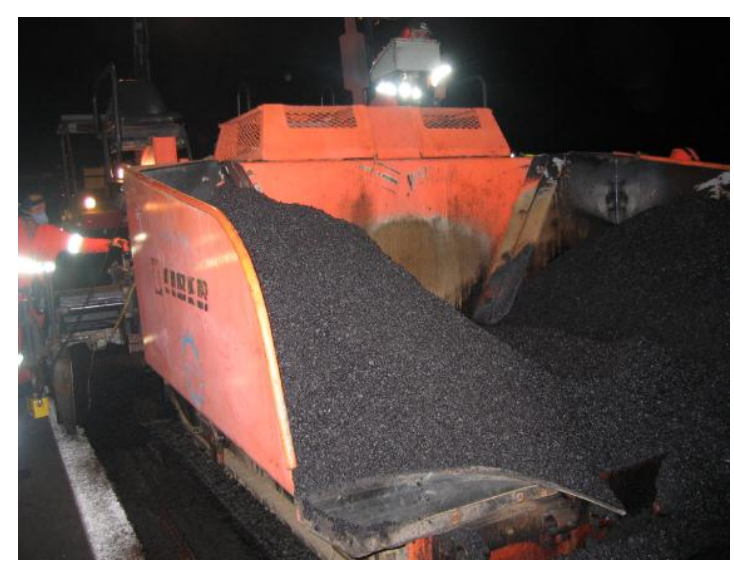

Figura 62 - Aspecto da mistura morna na vibroacabadora
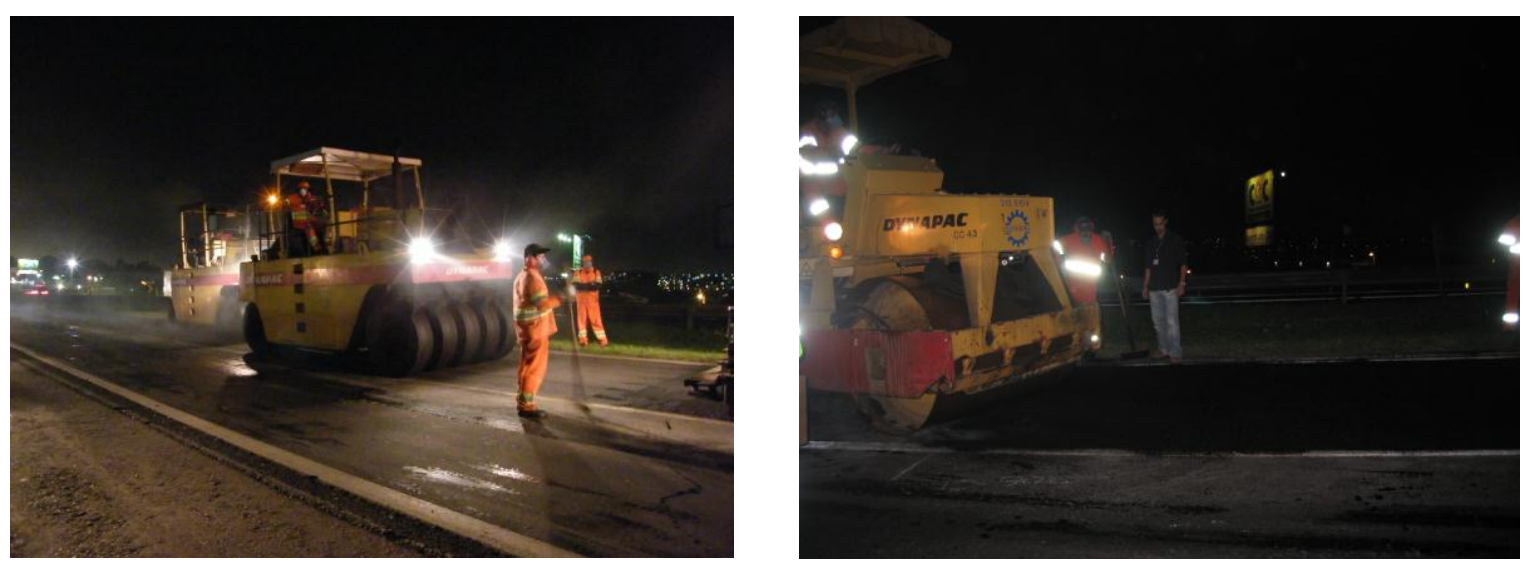

Figura 64 - Detalhes da compactação com rolos de pneus e metálico

Entretanto, após serem executados cerca de $70 \mathrm{~m}$ do trecho experimental com êxito, ocorreu um problema na vibroacabadora que levou à interrupção dos trabalhos. O serviço foi retomado alguns minutos depois, mas o problema persistiu e a obra passou a ser feita de maneira intermitente. Com isto, aproximadamente a partir do km $225+320$, a massa asfáltica começou a apresentar segregação devido a queda de temperatura, como mostra a Figura 65, seguindo com dificuldade até o km $225+600$. 


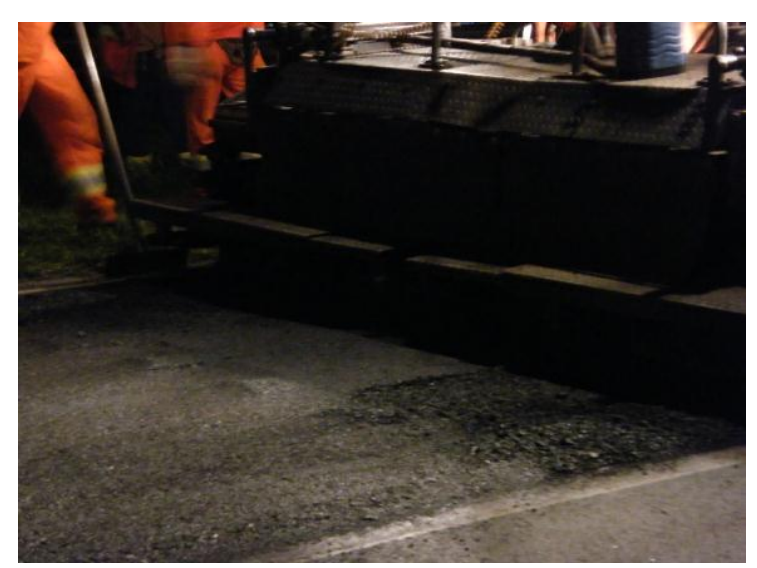

Figura 65 - Detalhe da segregação da massa asfáltica durante o lançamento em pista

\subsubsection{Controle tecnológico de compactação e espessura}

A concessionária NovaDutra forneceu os dados do controle de compactação e espessura, obtidos a partir de quatro CPs extraídos de pista logo após a obra. Como o teor de ligante na mistura morna de usina era de 5,2\%, no cálculo do VV foi considerada uma massa específica máxima teórica de $2,484 \mathrm{~g} / \mathrm{cm}^{3}$, segundo verificado no projeto da mistura (Figura 34) e confirmado após ensaio RICE (AASHTO T209-99) realizado no LTP/EPUSP. Os resultados são apresentados na Tabela 28.

Tabela 28 - Controle de compactação e espessura após a obra do trecho experimental na Rodovia Presidente Dutra

\begin{tabular}{cccc}
\hline Ponto & $\begin{array}{c}\text { Grau de compactação } \\
{[\%]}\end{array}$ & $\begin{array}{c}\text { Volume de vazios } \\
{[\%]}\end{array}$ & $\begin{array}{c}\text { Espessura } \\
{[\mathrm{cm}]}\end{array}$ \\
\hline 1 & 100,8 & 3,2 & 6,9 \\
\hline 2 & 98,1 & 5,8 & 6,0 \\
\hline 3 & 99,6 & 4,4 & 7,0 \\
\hline 4 & 100,5 & 3,5 & 7,0 \\
\hline \hline Média & 99,7 & 4,2 & 6,7 \\
\hline Desvio padrão & 1,2 & 1,2 & 0,5 \\
\hline
\end{tabular}

Com relação ao grau de compactação, a norma DNIT ES031/06 determina que este deve se situar entre 97 e 101\%. Com isto, nota-se que a mistura morna alcançou tal objetivo. Já segundo as especificações de projeto, o VV deveria se situar entre 2,5 e $7,5 \%$, enquanto a camada deveria ter uma espessura acima de $5,7 \mathrm{~cm}(95 \%$ de $6 \mathrm{~cm})$. Deste modo, verifica-se que a mistura morna atendeu tais limites, levando o trecho a ser aprovado por compactação e espessura. 


\subsubsection{Ensaios laboratoriais de propriedades mecânicas e testes complementares com a mistura morna de usina}

A Figura 66 aponta um resumo esquemático dos ensaios de propriedades mecânicas e testes complementares com a mistura morna proveniente de usina, empregada no trecho experimental na Rodovia Presidente Dutra.

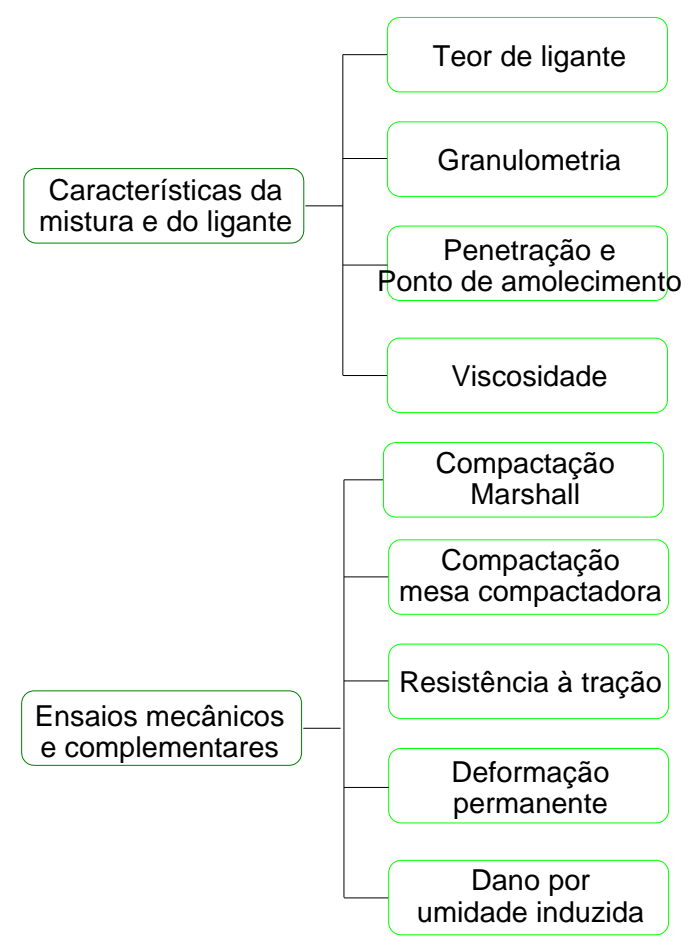

Figura 66 - Resumo dos ensaios dos ensaios de propriedades mecânicas e testes complementares com a mistura morna de usina empregada no trecho experimental na Rodovia Presidente Dutra

Para a moldagem de CPs em laboratório com a mistura morna de usina foi necessário reaquecê-la. Para tanto, empregou-se a temperatura de $120^{\circ} \mathrm{C}$, uma vez que esta foi a temperatura de compactação verificada em pista. Entretanto, entendese que isto pode ter elevado ainda mais o nível de envelhecimento da mistura asfáltica, para além daquele já sofrido em usina, o que poderia aumentar a rigidez do material e influenciar nas características mecânicas. Sebaaly et al. (2004), por exemplo, que estudaram misturas asfálticas de usina reaquecidas e compactadas em laboratório, em comparação com CPs extraídos de pista logo após a construção, concluíram que o reaquecimento em laboratório levou a um certo envelhecimento das misturas vindas de usina, em relação aos CPs de campo. 
Nos próximos itens são apresentados os resultados obtidos nos ensaios com a mistura morna de usina e, sempre que possível, também há a indicação dos valores encontrados com as misturas preparadas em laboratório, para fins de comparação.

\subsubsection{Características dos materiais da mistura morna de usina e de seu ligante asfáltico}

Uma amostra da mistura morna proveniente de usina, dividida em três partes, foi submetida à extração e recuperação de ligante e de agregados pelo método Abson (ASTM D1856-95). Tal ensaio foi realizado no laboratório da empresa Imperpav Projetos e Consultoria Ltda.

Foram então verificados o teor de ligante e a granulometria, sendo os resultados comparados com a indicação de projeto. De modo complementar, foram ainda avaliadas as características de consistência do asfalto recuperado, por meio de testes de penetração, ponto de amolecimento e viscosidade, confrontando-se os valores obtidos com os do asfalto virgem utilizado em laboratório, para se observar o impacto da temperatura de usinagem no envelhecimento do ligante. Infelizmente, como no caso deste trecho experimental não há um segmento em temperatura convencional, não é possível comparar os resultados de consistência do asfalto extraído da mistura morna com o que seria obtido com o de uma mistura a quente.

\section{$\underline{\text { Teor de ligante }}$}

A análise do teor de ligante das três amostras de mistura morna preparadas em usina indicaram um valor médio de 5,2\% ( $\pm 0,2 \%)$. Considerando-se que a quantidade de asfalto indicada para a preparação da mistura morna foi de $5,4 \%$ e que existe uma tolerância de usina de $\pm 0,3 \%$ (variando então entre 5,1 e 5,7\%), concluiu-se que o valor médio encontrado se enquadra dentro do aceitável. Com base neste resultado, a mistura morna de campo se aproxima das configurações de materiais da WMA2 TP+0,2\% estudada em laboratório. 


\section{Granulometria}

A Figura 67 apresenta a curva granulométrica obtida por peneiramento do material recuperado, onde é possível observar que há bastante similaridade com aquela de projeto.

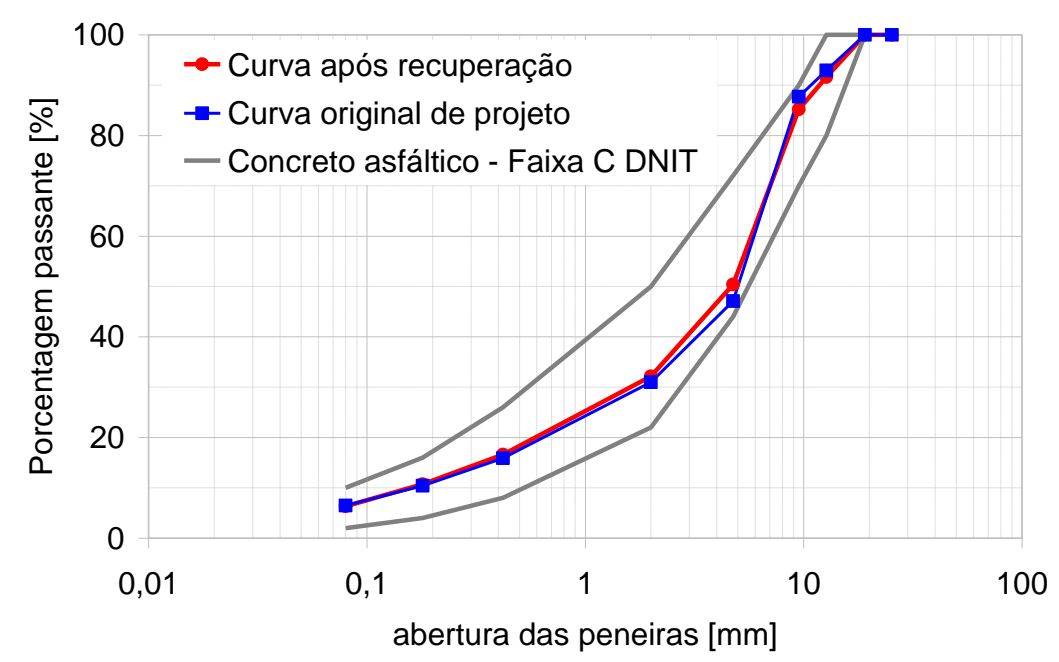

Figura 67 - Curva granulométrica após extração do ligante e recuperação

\section{$\underline{\text { Penetração e Ponto de amolecimento }}$}

A Figura 68 apresenta os valores de penetração e ponto de amolecimento encontrados com o ligante recuperado da mistura morna de usina, em comparação com o asfalto virgem utilizado em laboratório, tanto puro quanto misturado ao aditivo. Estes ensaios foram realizados segundo as especificações NBR 6576 (penetração) e NBR 6560 (ponto de amolecimento), como forma de verificar o envelhecimento sofrido pelo ligante na usinagem. 


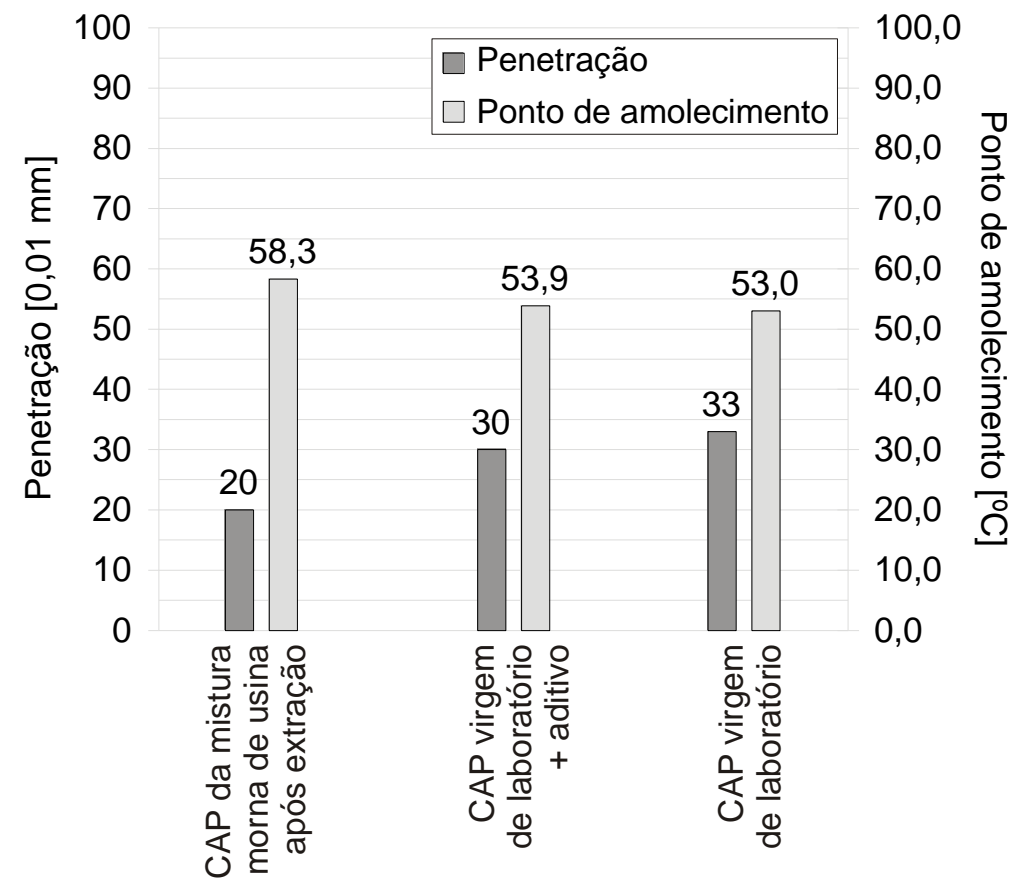

Figura 68 - Penetração e Ponto de amolecimento médios do asfalto extraído e recuperado, em comparação com o ligante virgem com e sem aditivo

Embora não se tenha o valor de um ligante pertencente a uma mistura a quente para a referência, observa-se que o asfalto extraído e recuperado apresentou penetração significativamente mais baixa que a do material virgem utilizado em laboratório, tanto com quanto sem aditivo. Do mesmo modo, o ponto de amolecimento também foi alterado, aumentando em relação aos ligantes virgens, possivelmente em decorrência do envelhecimento pela usinagem.

A variação da consistência do asfalto devido ao envelhecimento na usinagem pode ser simulada em laboratório em ensaio de RTFOT (Rolling Thin Film Oven Test ou estufa de filme fino rotativo, segundo ASTM D2872-04). Dentro deste contexto, a ANP (2005), determina que, para o CAP 30-45, a penetração retida mínima (razão entre a penetração após RTFOT e antes do ensaio) deve ser de $60 \%$ e o aumento máximo do ponto de amolecimento deve de $8^{\circ} \mathrm{C}$ após o teste RTFOT. Assim, levando-se em conta que este teste tem boa correlação com o envelhecimento em usina, e que o material avaliado passou por este processo, verifica-se que a mistura morna de usina sofreu variação dentro do que seria aceitável (penetração retida de $61 \%$ e aumento do ponto de amolecimento de cerca de $4^{\circ} \mathrm{C}$ ). 


\section{Viscosidade}

$O$ ensaio de viscosidade foi realizado em viscosímetro rotacional Brookfield, segundo a norma ASTM 4402-06. A Figura 69 apresenta os valores médios de viscosidade encontrados com o ligante recuperado da mistura morna de usina, em comparação com o asfalto virgem utilizado em laboratório, tanto puro quanto misturado ao aditivo. Mais uma vez observa-se que houve aumento da consistência do ligante proveniente da mistura morna de usina, corroborando com a hipótese de envelhecimento.

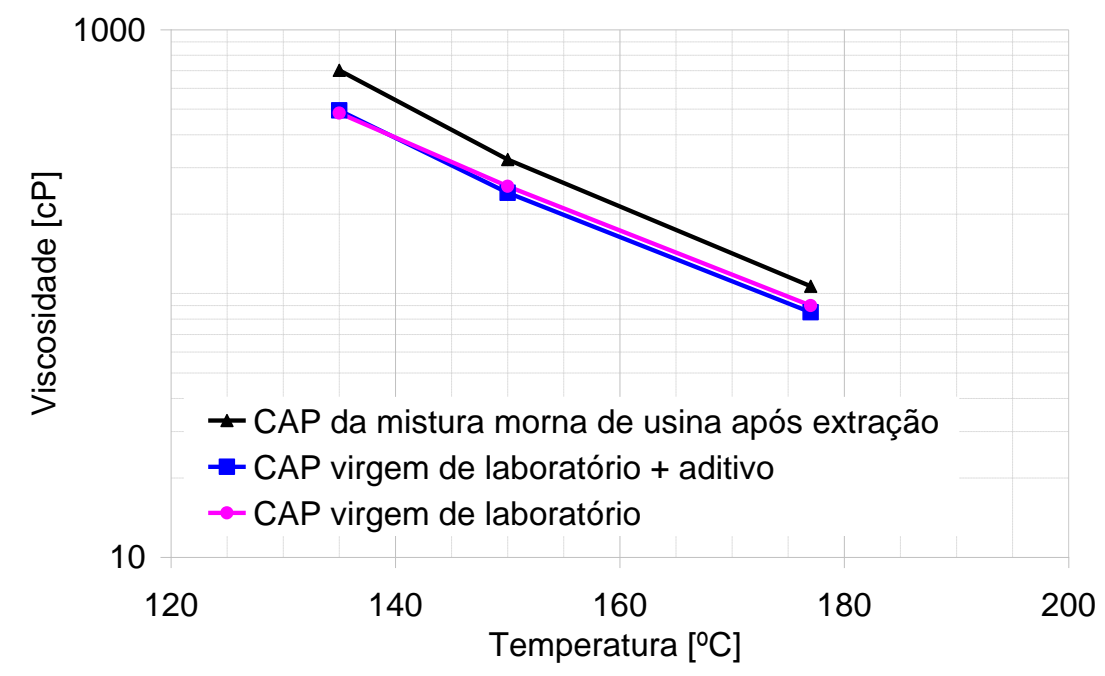

Figura 69 - Viscosidade média do asfalto extraído e recuperado, em comparação com o ligante virgem com e sem aditivo

\subsubsection{Compactação da mistura morna de usina}

\subsection{Marshall}

A compactação Marshall foi realizada segundo descrito no item 3.5.1.1. O resultado do VV médio é apresentado na Figura 70 (juntamente com os valores dos CPs extraídos de pista por ocasião do controle tecnológico e das misturas de laboratório). 


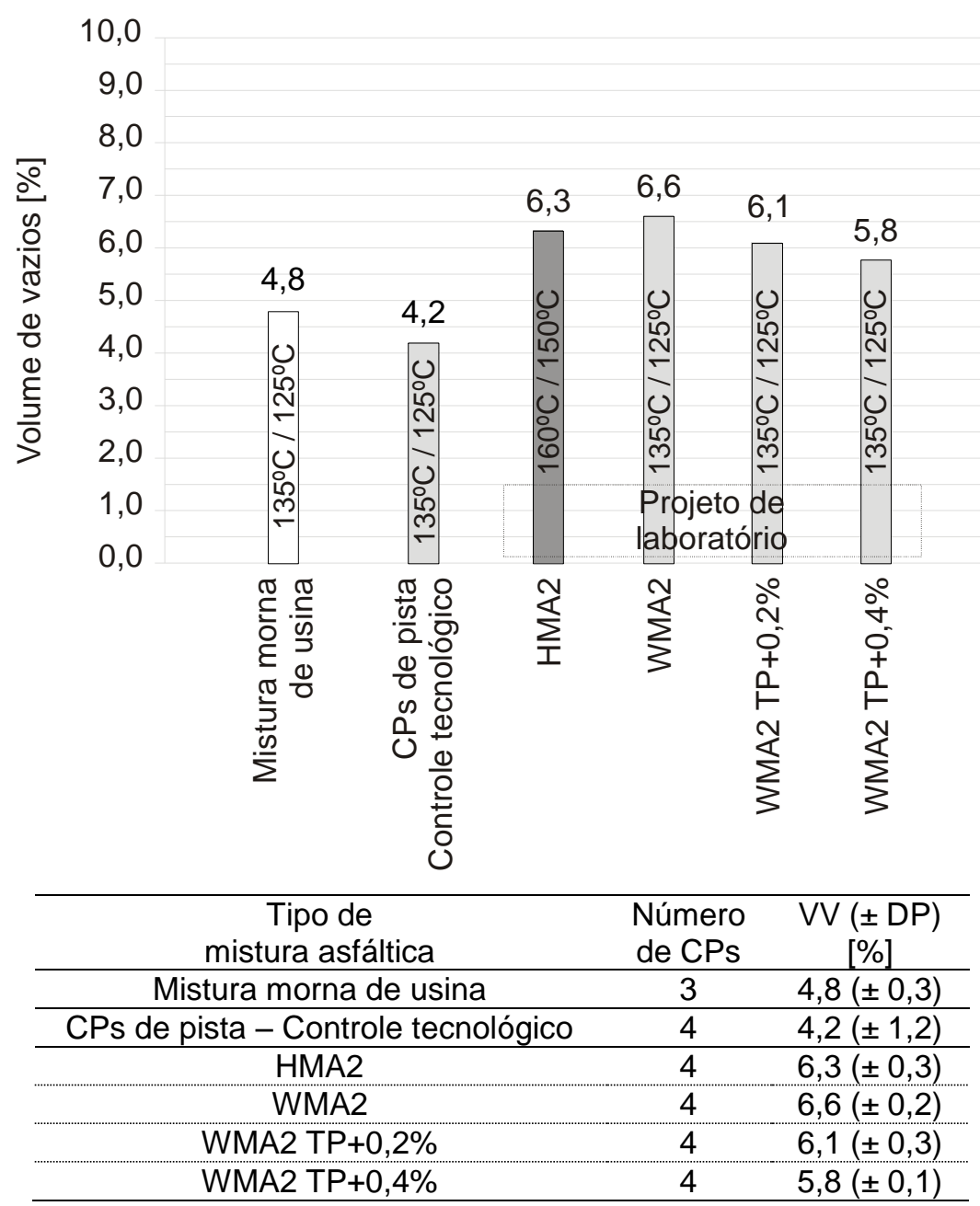

Figura 70 - Compactação da mistura morna de usina no compactador Marshall, em comparação com o volume de vazios de corpos de prova de pista e com as misturas de laboratório

De modo complementar, foi realizada uma análise de variância dos volumes de vazios da mistura morna de usina (compactação Marshall) e dos CPs extraídos de pista (compactação de campo) e o resultado mostrou que os valores são estatisticamente iguais.

Ao se comparar a mistura de usina com a WMA2 TP $+0,2 \%$ de laboratório (composição semelhante), nota-se que houve diferença significativa de VV, demonstrando que o processo de usinagem e o reaquecimento podem ter causado tal variação, ou ainda uma eventual mudança das características do ligante empregado.

Confrontando-se o resultado da habilidade de compactação Marshall da mistura morna de usina com os limites estabelecidos pela norma DNIT ES112/06 (VV entre 3 e $5 \%$ para camada de rolamento), conclui-se que a mesma enquadrouse na especificação. 


\subsection{Mesa compactadora}

A compactação em mesa compactadora foi realizada conforme descrito no item 3.5.1.2, moldando-se uma placa com a mistura morna de usina. Em seguida, tal placa teve as bordas eliminadas e foi submetida à pesagem hidrostática (AASHTO T166-07). A Figura 71 apresenta o resultado encontrado (juntamente com aqueles das misturas de laboratório).

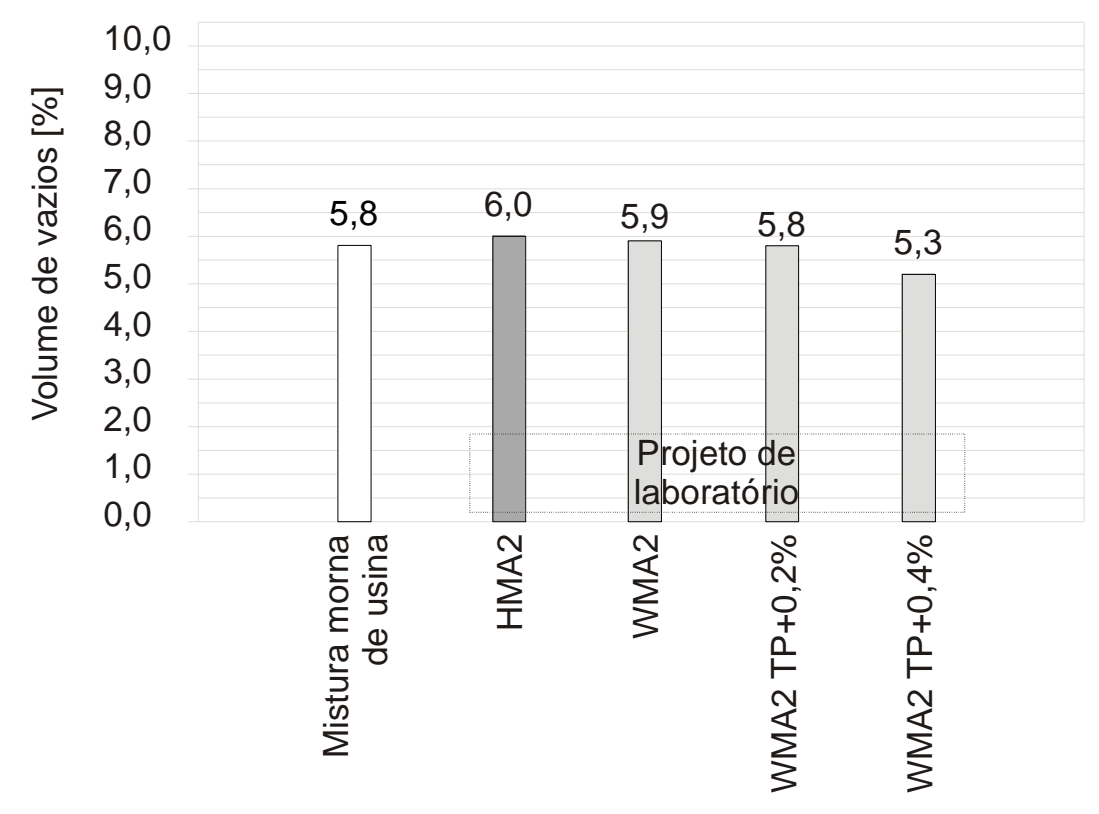

Figura 71 - Compactação da mistura morna de usina em mesa compactadora francesa, em comparação com as misturas de laboratório

Neste caso verifica-se que a mistura morna de usina apresentou o mesmo comportamento à compactação por rolagem que a mistura de laboratório (que continha a mesma configuração de materiais, WMA2 TP+0,2\%), além de atender a especificação francesa relativa ao VV de misturas tipo BBSG 3 0/14, que limita tal parâmetro de 5 a $8 \%$.

\subsubsection{Resistência à tração da mistura morna de usina}

O ensaio para determinação da RT foi realizado conforme descrito no item 3.5.2. A Figura 72 apresenta os valores médios de RT, bem como os de VV médio dos CPs testados (juntamente com os resultados das misturas de laboratório). 


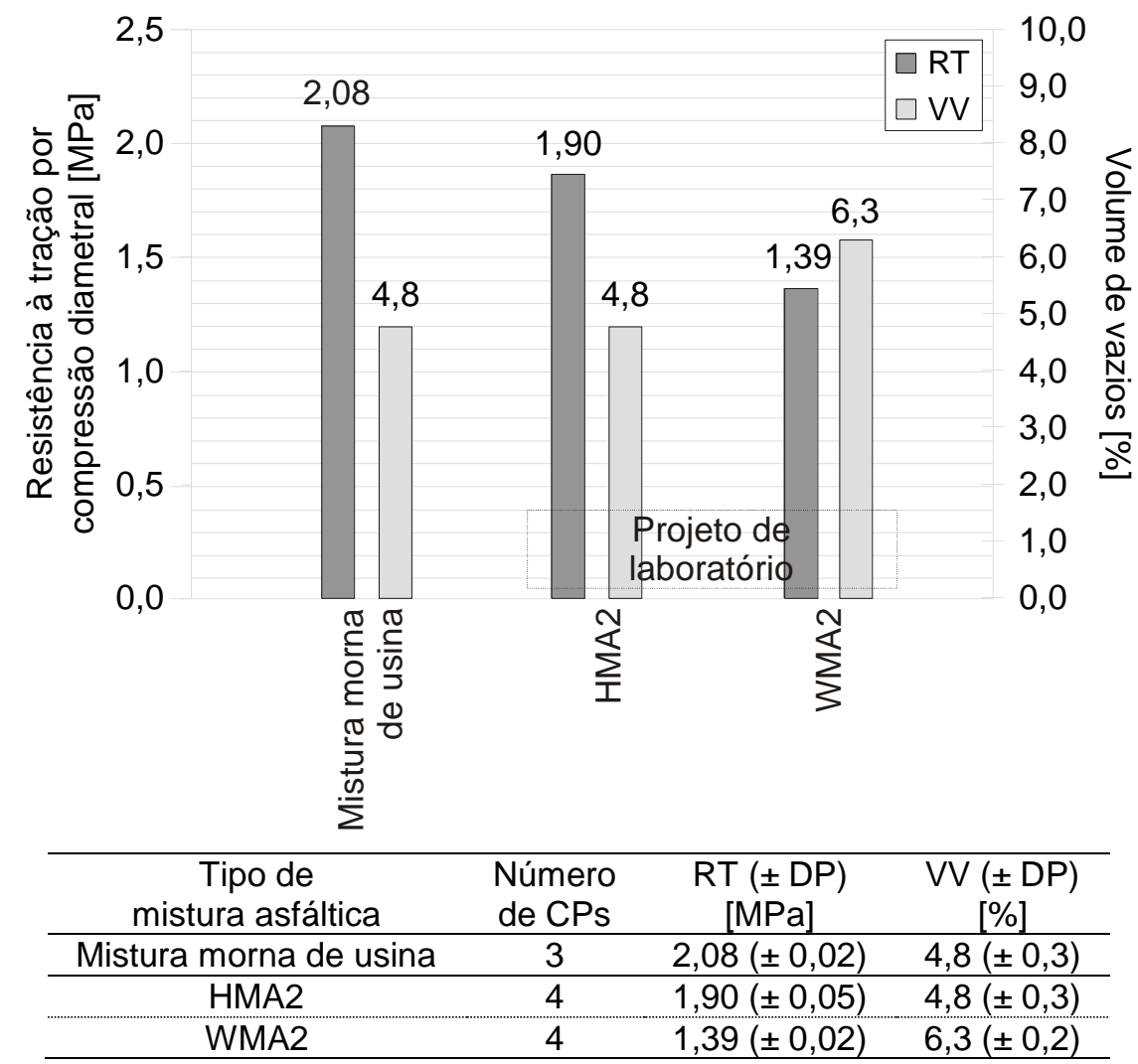

Figura 72 - Resistência à tração da mistura morna de usina, em comparação com as misturas de laboratório

Foram realizadas análises de variância de $\mathrm{RT}$ e de VV entre a mistura morna de usina e aquelas de laboratório. Os resultados indicaram que o material de campo se mostrou similar à HMA2 e estatisticamente diferente à WMA2, onde o VV mais elevado desta última e um possível envelhecimento no processo de reaquecimento podem ter sido responsáveis pela diferença de comportamento com o material de pista.

Por fim, considerando-se que a norma DNIT ES031/06 determina que a mistura asfáltica deve apresentar uma RT de pelo menos 0,65 MPa (para camada de rolamento), verifica-se que a mistura morna de usina atendeu a especificação.

\subsubsection{Deformação permanente da mistura morna de usina}

Um par de placas foi moldado, segundo exposto no item 3.5.1.2, para o ensaio de deformação permanente em simulador de tráfego, conforme descrito no item 3.5.4. O resultado médio da evolução do afundamento em trilha de roda é apresentado na Figura 73 (juntamente com o obtido com as misturas de laboratório). 


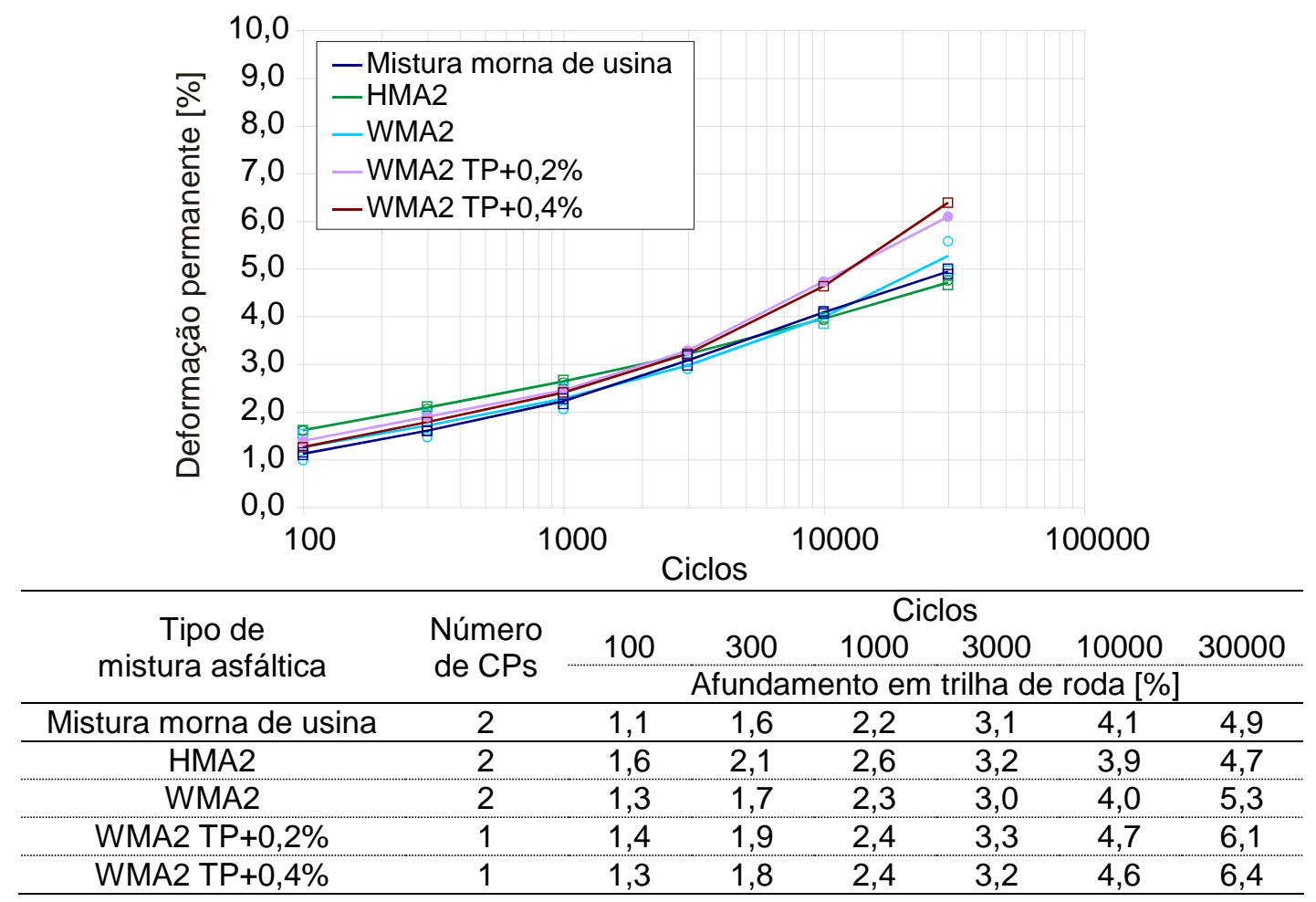

Figura 73 - Deformação permanente em trilha de roda da mistura morna de usina, em comparação com as misturas de laboratório

Nota-se que a mistura morna de usina apresentou menores afundamentos que a WMA2 TP+0,2\% (composição semelhante), cuja diferença pode ter sido causada por envelhecimento devido ao reaquecimento do material de usina.

Em relação à especificação francesa de BBSG 3 0/14 (NF P 98-130, 1999a) e à recomendação indicada pelo LTP/EPUSP, a mistura morna de usina satisfaz o limite aconselhável de afundamento em trilha de roda para tráfego pesado (caso da Rodovia Presidente Dutra), que é de 5\%.

\subsubsection{Dano por umidade induzida da mistura morna de usina}

O ensaio de dano por umidade induzida foi realizado segundo descrito no item 3.5.5 e a Tabela 29 apresenta os resultados médios obtidos, bem como o número de CPs empregados (metade na situação de condicionamento à água e a outra metade como referência). Além disso, têm-se ainda os valores obtidos com as misturas de laboratório, para fins de comparação. Em seguida, são indicados os resultados de análise de variância dos parâmetros de RT e VV na Tabela 30. 
Tabela 29 - Resultados do ensaio de dano por umidade induzida da mistura morna usina, em comparação com as misturas de laboratório

\begin{tabular}{cccc} 
& $\begin{array}{c}\text { Mistura morna } \\
\text { de usina }\end{array}$ & HMA2 & WMA2 TP $+0,4 \%$ \\
\hline Quantidade de CPs & 6 & 8 & 8 \\
\hline RTnc $( \pm$ DP) $[\mathrm{MPa}]$ & $1,78( \pm 0,07)$ & $1,65( \pm 0,03)$ & $1,18( \pm 0,14)$ \\
\hline VVnc $( \pm$ DP) $[\%]$ & $7,0( \pm 0,3)$ & $6,4( \pm 0,2)$ & $6,9( \pm 0,6)$ \\
\hline RTc $( \pm$ DP) $[\mathrm{MPa}]$ & $1,63( \pm 0,13)$ & $1,49( \pm 0,08)$ & $1,05( \pm 0,04)$ \\
\hline VVc $( \pm$ DP) $[\%]$ & $6,4( \pm 0,3)$ & $6,9( \pm 0,3)$ & $6,5( \pm 0,3)$ \\
\hline RRT & 0,92 & 0,90 & 0,89 \\
\hline
\end{tabular}

Tabela 30 - Análise de variância da resistência à tração e volume de vazios da mistura morna de usina, em comparação com as misturas de laboratório, para o ensaio de dano por umidade induzida

\begin{tabular}{|c|c|c|c|c|c|}
\hline \multirow{2}{*}{$\begin{array}{l}\text { Tipo de } \\
\text { mistura } \\
\text { asfáltica }\end{array}$} & & \multicolumn{4}{|c|}{ Mistura morna de usina } \\
\hline & Parâmetro & RTnc & VVnc & RTc & VVc \\
\hline \multirow{4}{*}{ HMA2 } & RTnc & ED & -- & -- & -- \\
\hline & VVnc & -- & ED & -- & -- \\
\hline & RTc & -- & -- & El & -- \\
\hline & VVc & -- & -- & -- & ED \\
\hline \multirow{4}{*}{$\begin{array}{c}\text { WMA2 } \\
\text { TP }+0,4 \%\end{array}$} & RTnc & ED & -- & -- & -- \\
\hline & VVnc & -- & El & -- & -- \\
\hline & RTc & -- & -- & ED & -- \\
\hline & VVc & -- & -- & -- & $\mathrm{El}$ \\
\hline
\end{tabular}

Nota-se que a RRT da mistura de usina apresentou resultado satisfatório perante a norma DNIT ES031/06 (acima de 0,7), além de ter mostrado valor muito semelhante ao das misturas de laboratório. Com isto, concluiu-se que o aditivo se mostrou eficiente na manutenção da resistência ao dano por umidade induzida, além de não ter sofrido degradação com o processo de usinagem.

\subsubsection{Verificação de volume de vazios e ensaios de propriedades mecânicas com corpos de prova extraídos de pista}

Após a execução do trecho experimental na Rodovia Presidente Dutra foram feitas extrações de CPs com sonda rotativa (Figura 74) para a realização de ensaios posteriores. Tais retiradas foram feitas após um mês (dezembro/2009) e depois de onze meses (outubro/2010) da execução da obra, nos pontos do pavimento indicados na Figura 75 (note-se que também estão incluídos os locais relativos aos 
CPs extraídos por ocasião do controle tecnológico, em novembro/2009). No total foram extraídos $22 \mathrm{CPs}$ no trecho experimental de mistura morna.
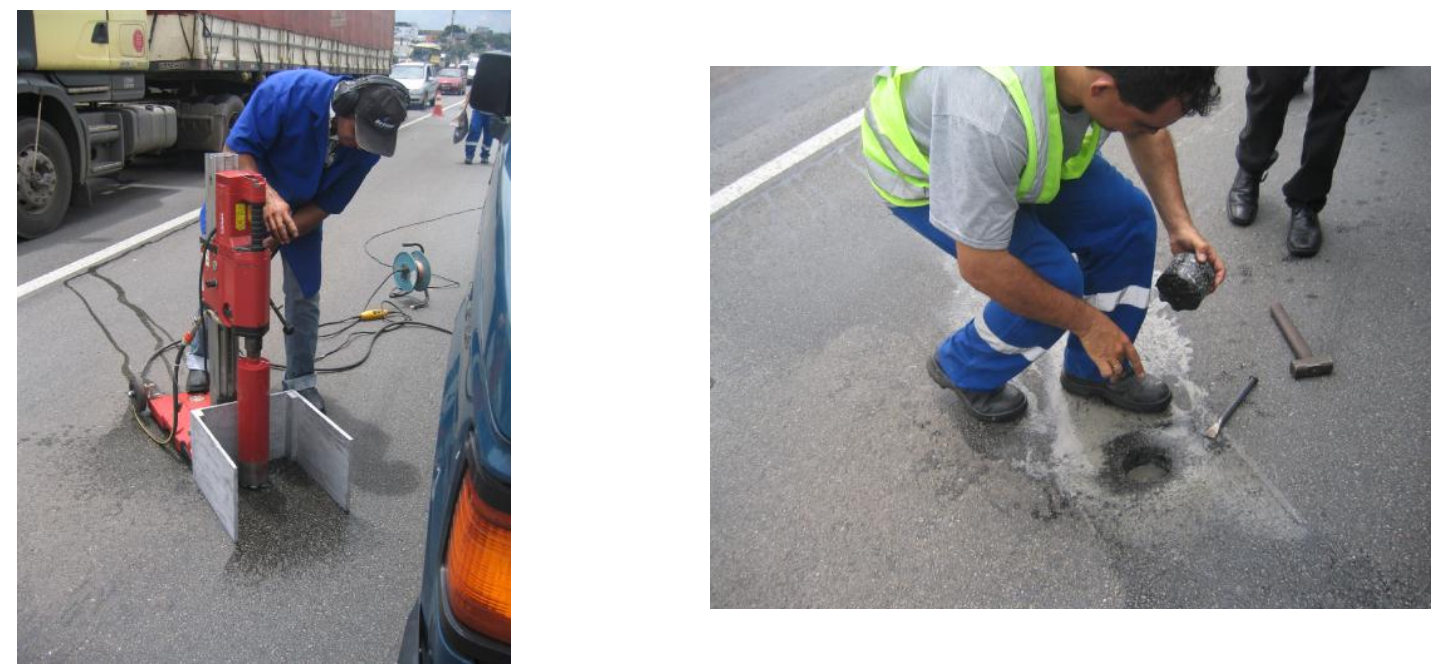

Figura 74 - Extração de corpos de prova com sonda rotativa na Rodovia Presidente Dutra

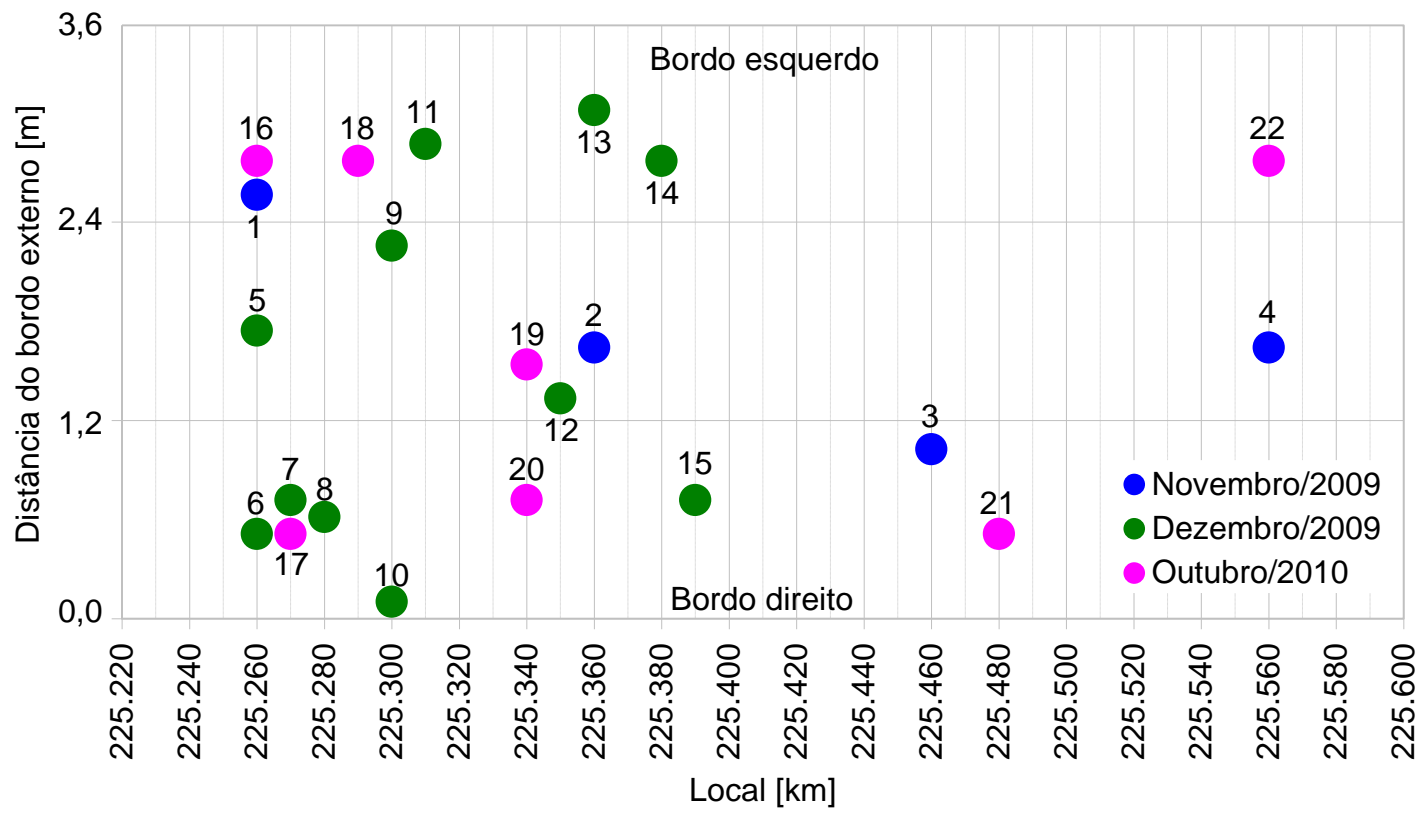

Figura 75 - Pontos de retirada de corpos de prova na Rodovia Presidente Dutra após a execução do trecho experimental

A Figura 76 aponta um resumo esquemático dos ensaios realizados em laboratório com os CPs extraídos de pista. Em seguida, nos próximos itens, são apresentados os resultados obtidos nestes testes onde, sempre que possível, 
também há a indicação dos valores encontrados com a mistura de usina, além daquelas de laboratório, para fins de comparação.

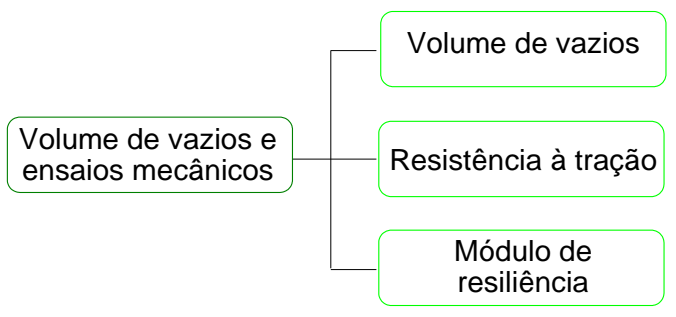

Figura 76 - Resumo dos ensaios laboratoriais com corpos de prova extraídos do trecho experimental na Rodovia Presidente Dutra

\subsubsection{Volume de vazios}

O VV dos CPs extraídos em pista foi determinado por pesagem hidrostática, conforme descrito no item 3.5.1.1. A Figura 77 apresenta os resultados de VV médio das amostras retiradas em três ocasiões: no controle tecnológico logo após a obra (novembro/2009), depois de um mês (dezembro/2009) e após onze meses (outubro/2010) da execução do trecho experimental. 


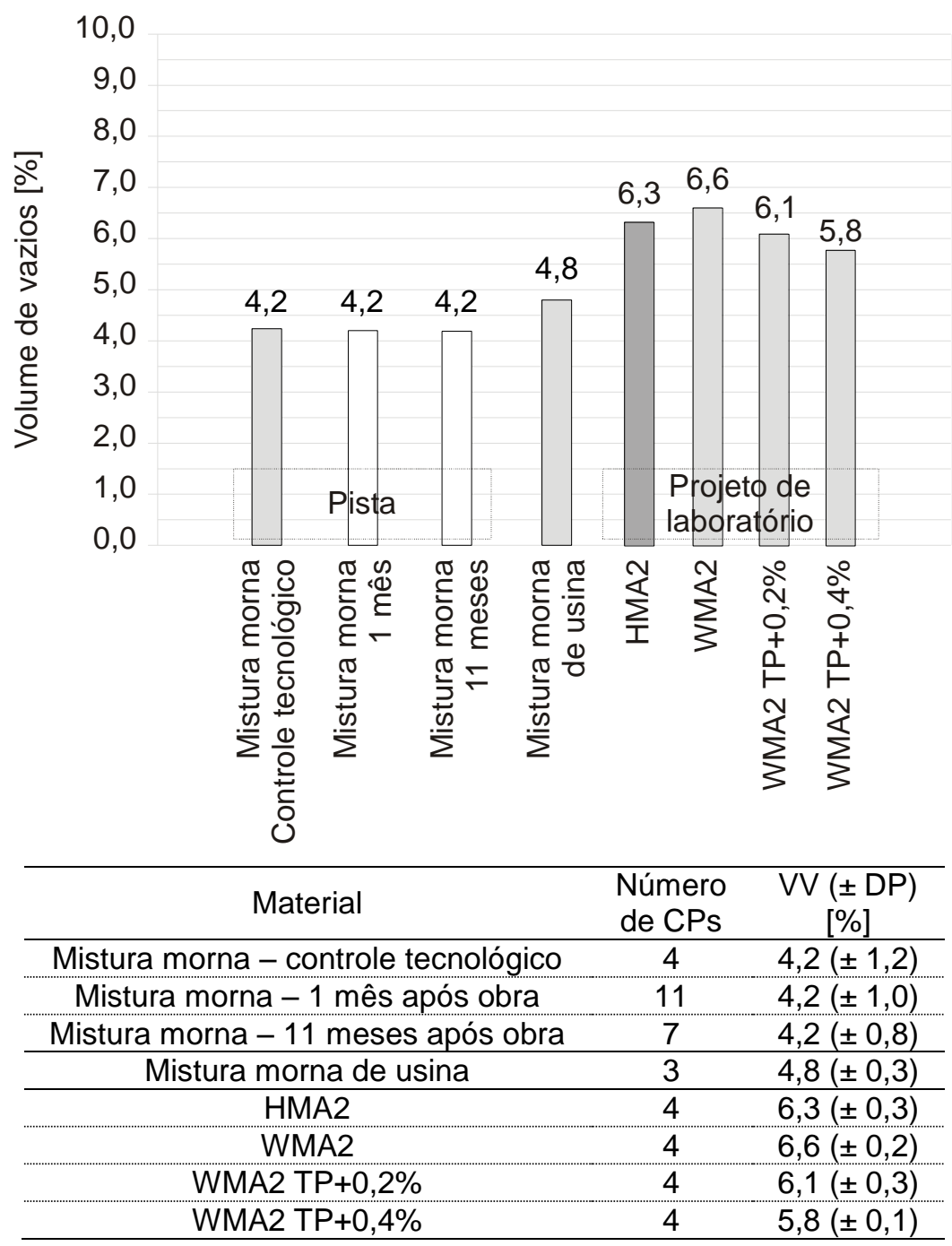

Figura 77 - Volume de vazios de corpos de prova extraídos do trecho experimental, em comparação com a mistura morna de usina e com as misturas de laboratório

Nota-se que a mistura morna no trecho experimental não sofreu alteração do VV médio no primeiro ano após a construção, apesar de haver uma certa variabilidade de resultados. Como a maior parte dos CPs broqueados se concentrava na área de trilha de roda, a manutenção do VV leva a crer que não houve formação de deformação permanente nestes locais.

\subsubsection{Resistência à tração}

O ensaio de RT com os CPs extraídos de pista foi realizado segundo descrito no item 3.5.2. Os resultados médios de RT e de VV são apresentados na Figura 78 (juntamente com valores das misturas de laboratório). 


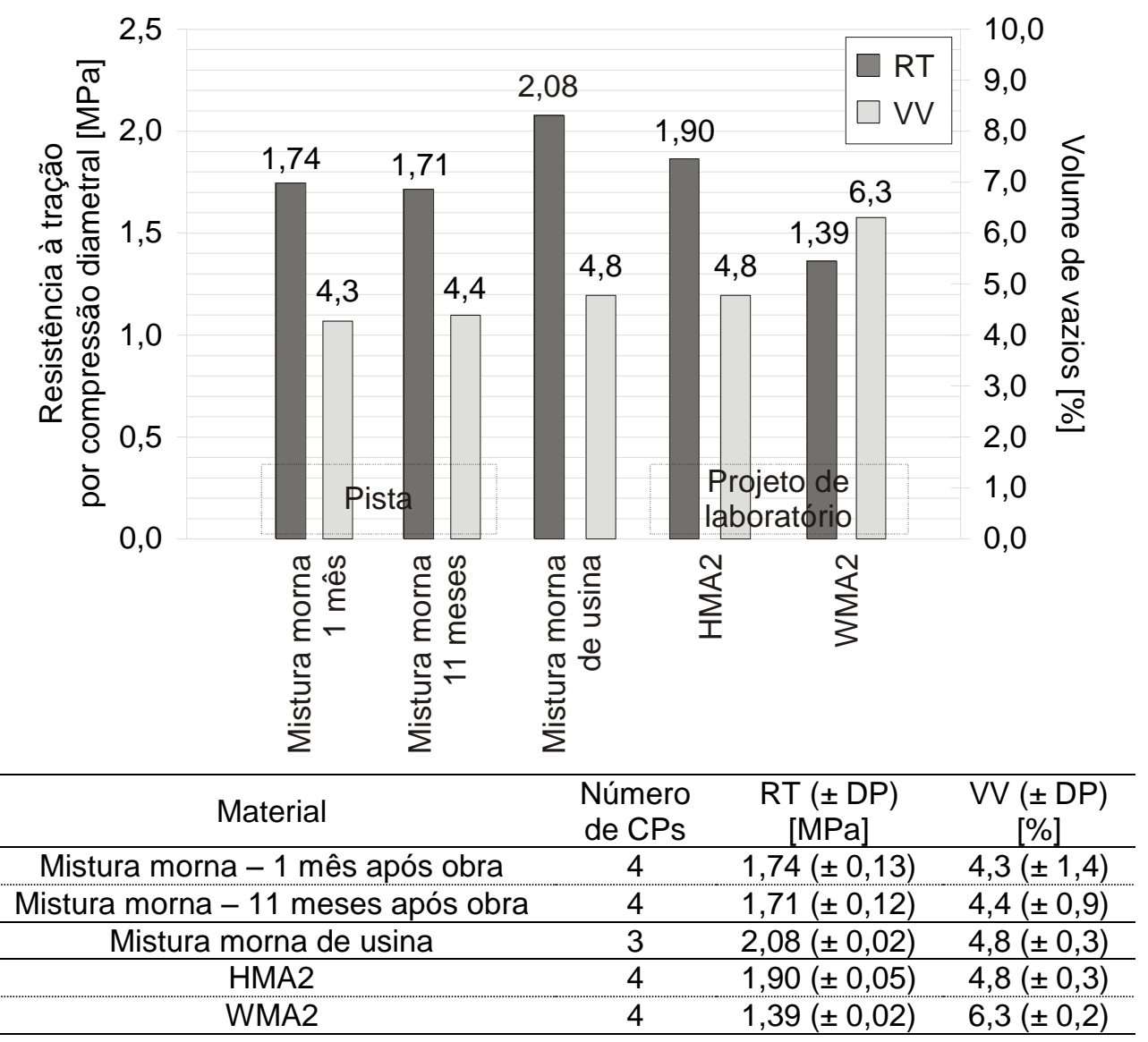

Figura 78 - Resistência à tração de corpos de prova extraídos do trecho experimental, em comparação com a mistura morna de usina e com as misturas de laboratório

A análise de variância dos valores de RT e de VV do grupo de CPs que foi extraído após um mês e daquele que foi retirado após onze meses mostrou que os resultados são estatisticamente iguais para ambos os parâmetros. Deste modo, concluiu-se que, do mesmo modo que no item anterior (VV), a RT se manteve em um mesmo patamar após quase um ano da execução do trecho experimental.

\subsubsection{Módulo de resiliência}

O ensaio de MR foi realizado segundo procedimento descrito no item 3.5.3, com CPs extraídos após um mês da obra do trecho experimental. Os resultados médios de MR e VV são apresentados na Figura 79 (juntamente com aqueles das misturas de laboratório). 


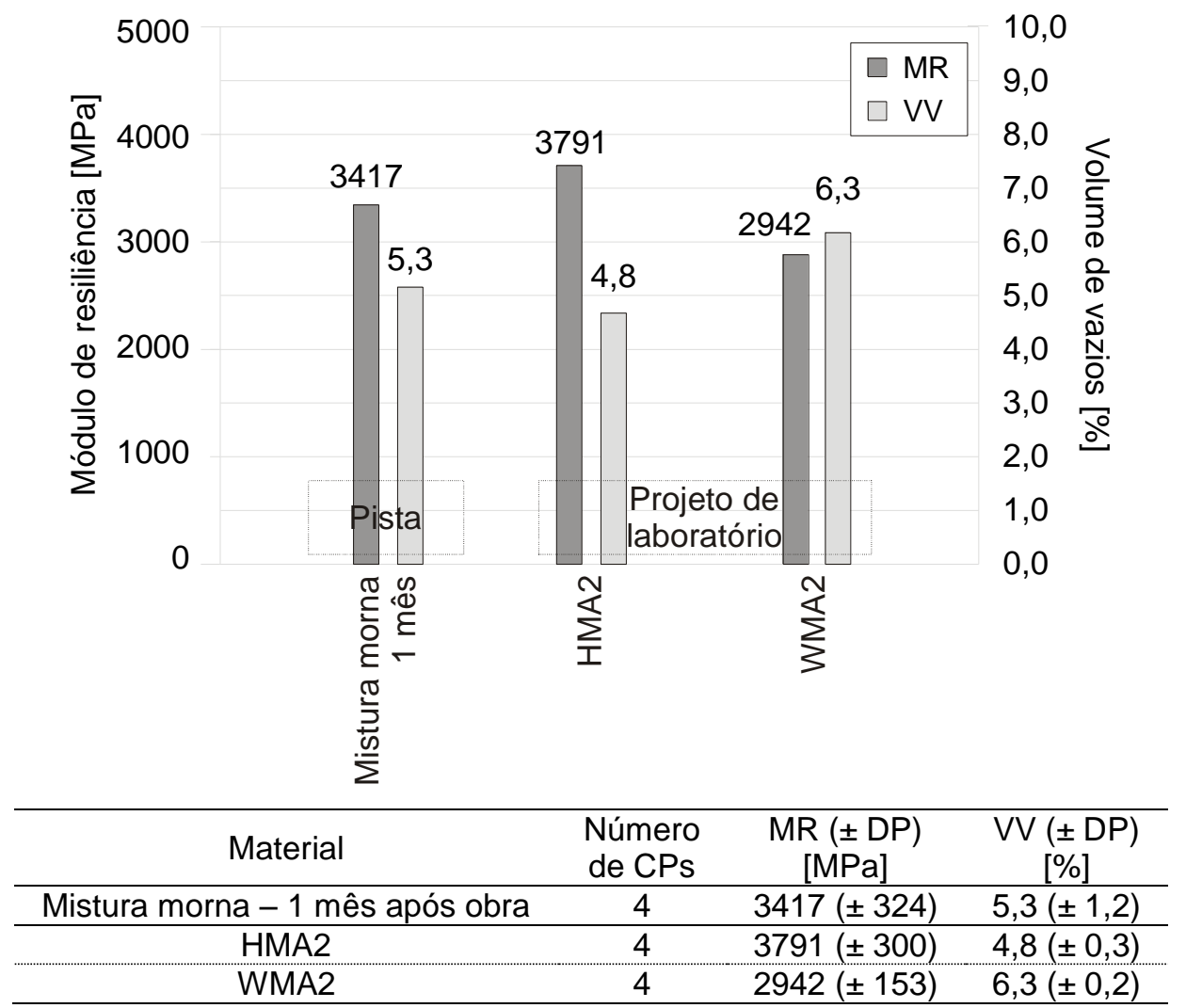

Figura 79 - Módulo de resiliência de corpos de prova extraídos do trecho experimental, em comparação com as misturas de laboratório

Foram realizadas análises de variância de $\mathrm{MR}$ e de $\mathrm{VV}$ dos CPs de pista em relação às misturas de laboratório. Os resultados indicaram que o material de campo se mostrou estatisticamente igual à HMA2 e ligeiramente diferente à WMA2, mas isto se deve à diferença de VV das misturas de laboratório, que provavelmente foi ocasionada por variações de temperatura durante a moldagem, conforme já mencionado anteriormente no item 3.5.3.

\subsubsection{Ensaios em pista}

Após três meses da execução do trecho experimental (fevereiro/2010), foram feitos ensaios em pista para observar as condições superficiais do revestimento asfáltico em termos de textura, com mancha de areia e pêndulo britânico. Nesta mesma ocasião, também foi feito um levantamento da situação estrutural daquele pavimento, por meio de deflexões em viga Benkelman. 
Depois de oito meses da obra (julho/2010), foi feita uma nova visita ao segmento-teste e nesta oportunidade foram novamente levantados os valores de deflexões, desta vez não só com viga Benkelman, mas também com FWD.

Cabe mencionar que em ambas ocasiões se verificou que 0 trecho experimental não possuía defeitos e nem trilha de roda visíveis.

A Figura 80 apresenta um resumo esquemático dos ensaios realizados em pista, para determinação das condições de textura, irregularidade e deflexões.

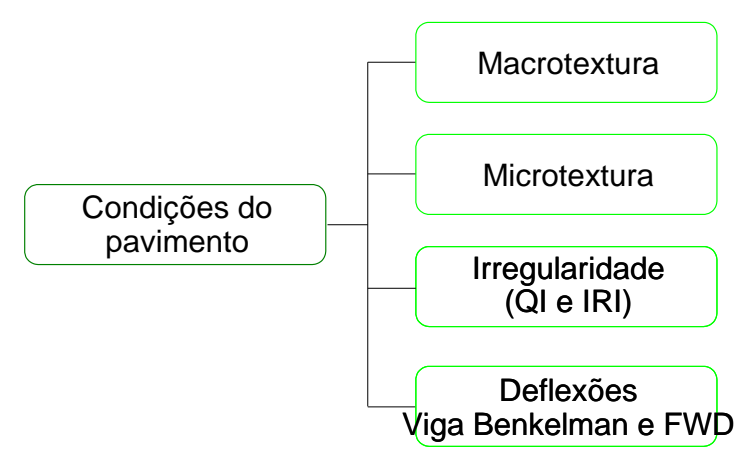

Figura 80 - Resumo dos ensaios em pista no trecho experimental da Rodovia Presidente Dutra

\subsubsection{Macro e microtextura}

Para verificação da macro e microtextura do pavimento da Rodovia Presidente Dutra foram realizados ensaios de mancha de areia (ASTM E965-06) e de pêndulo britânico (ASTM E303-08), conforme ilustrado na Figura 81.
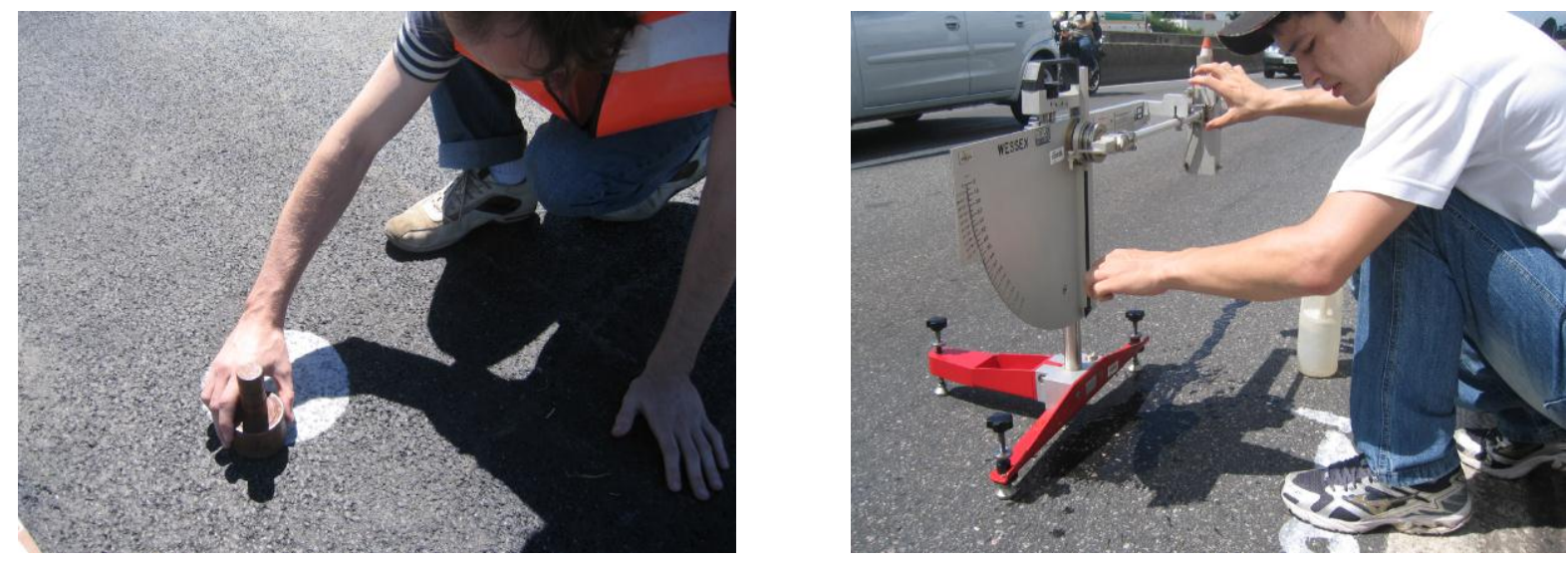

Figura 81 - Levantamento de macrotextura e microtextura com mancha de areia e pêndulo britânico 
A Tabela 31 indica a classificação da macrotextura em função da altura média de mancha de areia (HS), enquanto a Tabela 32 apresenta a classificação segundo o valor de resistência à derrapagem (VRD) pelo pêndulo britânico, conforme apresentado em Bernucci et al. (2008).

Tabela 31 - Classificação da macrotextura em função da altura de mancha de areia

\begin{tabular}{cc}
\hline Classe & $\begin{array}{c}\mathrm{HS} \\
{[\mathrm{mm}]}\end{array}$ \\
\hline Muito fina ou muito fechada & $\mathrm{HS} \leq 0,20$ \\
\hline Fina ou fechada & $0,20<\mathrm{HS} \leq 0,40$ \\
\hline Média & $0,40<\mathrm{HS} \leq 0,80$ \\
\hline Grosseira ou aberta & $0,80<\mathrm{HS} \leq 1,20$ \\
\hline Muito grosseira ou muito aberta & $\mathrm{HS}>1,20$ \\
\hline
\end{tabular}

Tabela 32 - Classificação da microtextura em função do valor de resistência à derrapagem por pêndulo britânico

\begin{tabular}{cc}
\hline Classe & $\begin{array}{c}\text { VRD } \\
{[\mathrm{mm}]}\end{array}$ \\
\hline Perigosa & $<25$ \\
\hline Muito lisa & $25 \leq \mathrm{VRD} \leq 31$ \\
\hline Lisa & $32 \leq \mathrm{VRD} \leq 39$ \\
\hline Insuficientemente rugosa & $40 \leq \mathrm{VRD} \leq 46$ \\
\hline Medianamente rugosa & $47 \leq \mathrm{VRD} \leq 54$ \\
\hline Rugosa & $55 \leq \mathrm{VRD} \leq 75$ \\
\hline Muito rugosa & VRD $>75$ \\
\hline
\end{tabular}

Ainda segundo Bernucci et al. (2008), tem-se recomendado que a macrotextura de pavimentos asfálticos se situe entre $0,6 \mathrm{~mm}$ e $1,2 \mathrm{~mm}$ de altura média de mancha de areia, enquanto que o VRD mínimo recomendado é de 47, a fim de garantir ao menos uma microtextura medianamente rugosa.

Nesta pesquisa os levantamentos foram feitos a cada $20 \mathrm{~m}$, da estaca $225+200$ (ainda no revestimento antigo) à $225+320$ (já no trecho experimental de mistura morna), com os ensaios de mancha de areia e com pêndulo britânico sendo sempre feitos próximos um ao outro. Os resultados são apresentados respectivamente na Figura 82 e na Figura 83. 


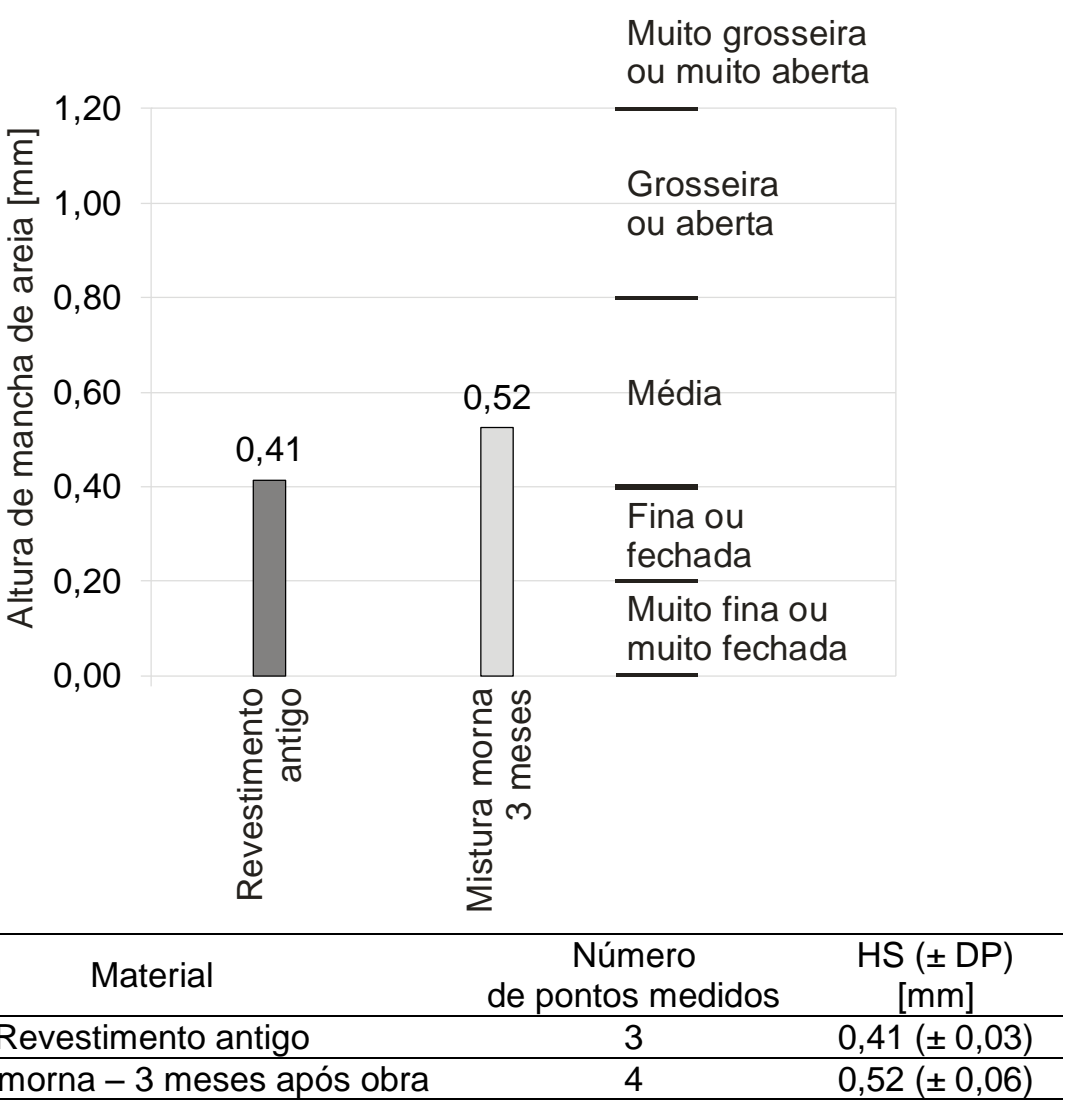

Figura 82 - Altura de mancha de areia após três meses da execução do trecho experimental

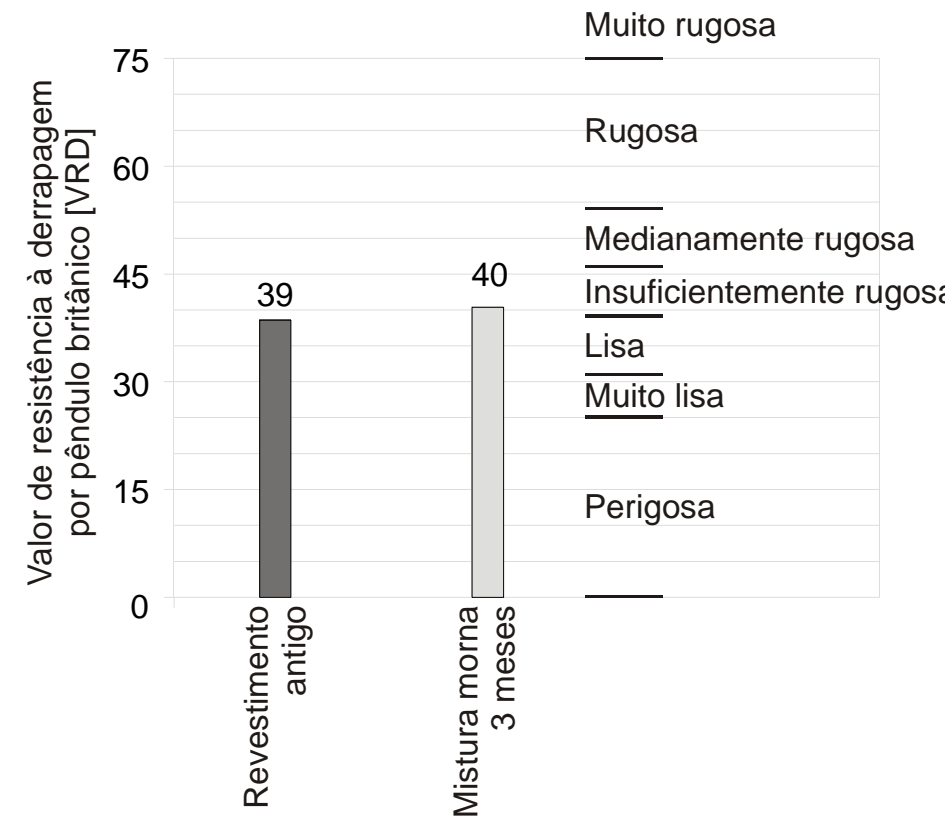

\begin{tabular}{ccc}
\hline Material & $\begin{array}{c}\text { Número } \\
\text { de pontos medidos }\end{array}$ & VRD ( \pm DP $)$ \\
\hline Revestimento antigo & 3 & $39( \pm 4)$ \\
\hline Mistura morna -3 meses após obra & 4 & $40( \pm 6)$ \\
\hline
\end{tabular}

Figura 83 - Valor de resistência à derrapagem por pêndulo britânico após três meses da execução do trecho experimental 
Nota-se que a macro e a microtextura da camada de rolamento com mistura morna foi classificada, no geral, como média, o que decorre da graduação densa usada, não havendo relação com o tipo de asfalto empregado. Neste caso, o uso de uma granulometria com alguma descontinuidade teria sido benéfico neste sentido, aumentando a rugosidade do pavimento e, por consequência, a aderência.

\subsubsection{Irregularidade longitudinal}

Após sete meses da execução do trecho experimental, fez-se um levantamento da condição funcional do pavimento com perfilômetro laser, para a determinação da irregularidade longitudinal pelos índices QI e IRI. As leituras foram feitas a cada $100 \mathrm{~m}$, com o veículo operando em cerca de $100 \mathrm{~km} / \mathrm{h}$. Os resultados estão indicados na Figura 84, juntamente com os valores obtidos antes da obra e os admissíveis recomendados pelo Manual de Restauração de Pavimentos Asfálticos do DNIT (2006).

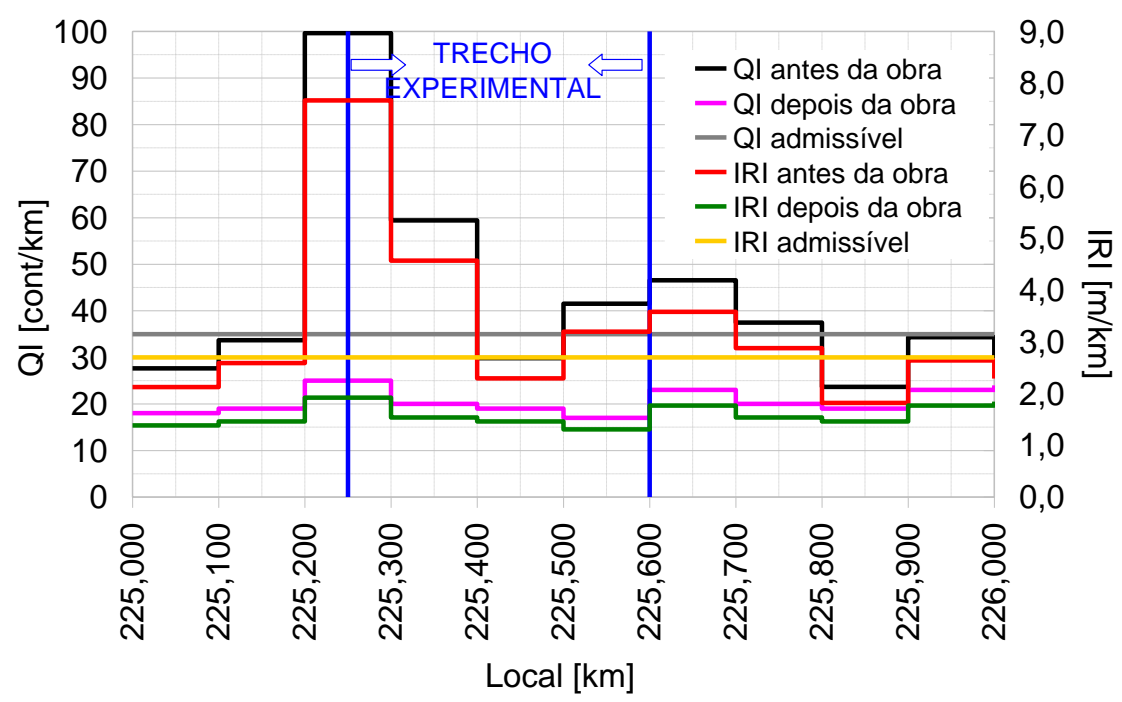

Figura 84 - Resultado de QI e IRI antes e após sete meses da execução do trecho experimental

Observa-se que o novo revestimento trouxe melhoria das condições de irregularidade, que apresentava pontos bastante acima do recomendável antes da obra, tanto de QI quanto de IRI. 


\subsubsection{Deflexões}

O levantamento de deflexões foi realizado por viga Benkelman eletrônica (Figura 85), alternando-se o ponto de leitura entre trilhas esquerda e direita da pista. A Figura 86 apresenta os resultados após três meses e depois de oito meses da execução do trecho experimental. Cabe mencionar que ambos levantamentos foram feitos com o mesmo equipamento e com a mesma equipe.

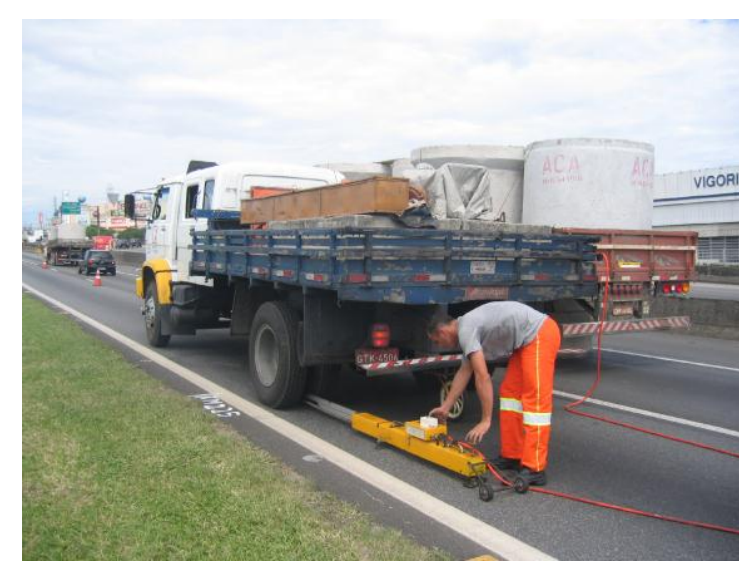

Figura 85 - Levantamento de deflexões com viga Benkelman no trecho experimental

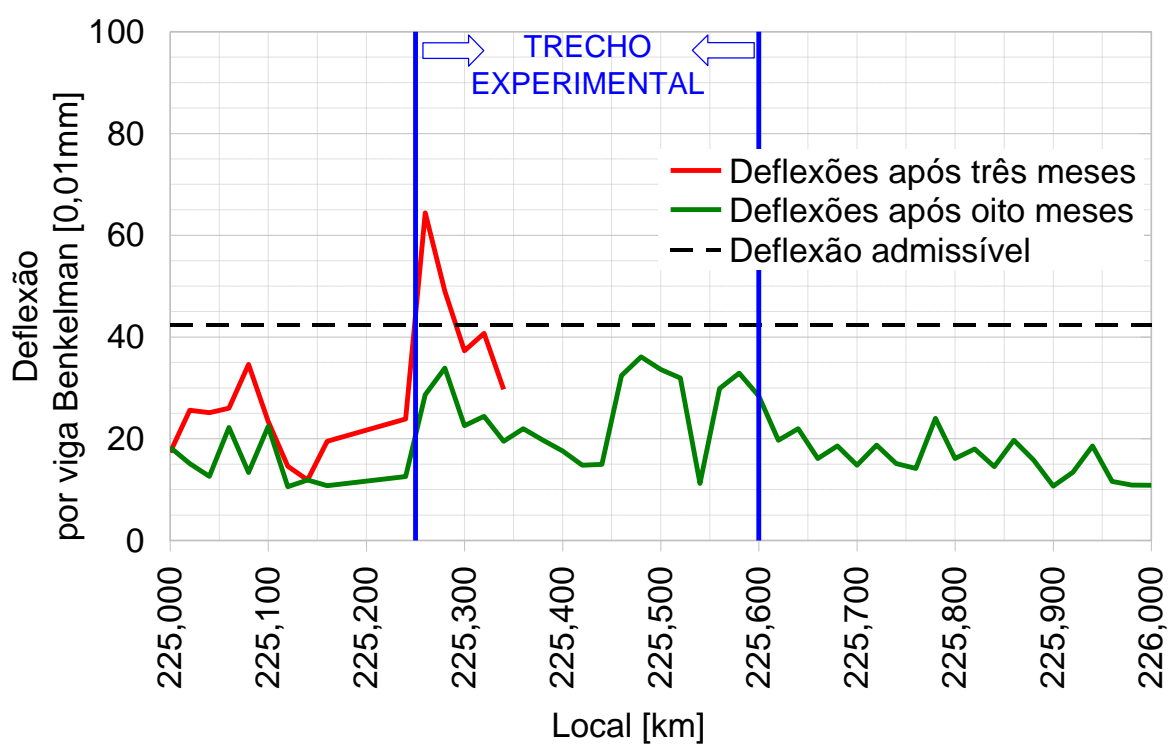

Figura 86 - Resultado de levantamento de deflexões com viga Benkelman após três meses e depois de oito meses da execução do trecho experimental

Nota-se que dentre as deflexões medidas pouco tempo depois da obra (fevereiro/2010), havia um ponto com valor acima do admissível, mas isto estava relacionado com a localização de um dreno transversal naquela estaca, conforme 
mencionado pela equipe que operou a viga Benkelman, o que coincide com a indicação da Figura 57.

O novo levantamento com viga Benkelman após oito meses da obra (julho/2010) apontou deflexões mais baixas, mesmo com o revestimento antigo, o que pode estar relacionado com imprecisão de resultados. De qualquer modo, os valores se situaram abaixo da deflexão admissível.

Nesta mesma ocasião, depois de oito meses da execução do trecho experimental, fez-se também um novo levantamento de deflexões com FWD, mas em dois níveis de carregamento, sendo 4,1 t e 6,5 t, cujo resultado é apontado na Figura 87 , juntamente com os valores obtidos antes da obra. Cabe mencionar que normalmente este teste é feito com carga de 4,1 t, por corresponder ao semieixo padrão no Brasil que é de 8,2 t, mas também se obteve, de maneira complementar, os resultados referentes a um carregamento de 6,5 t (semieixo utilizado na França, por exemplo).

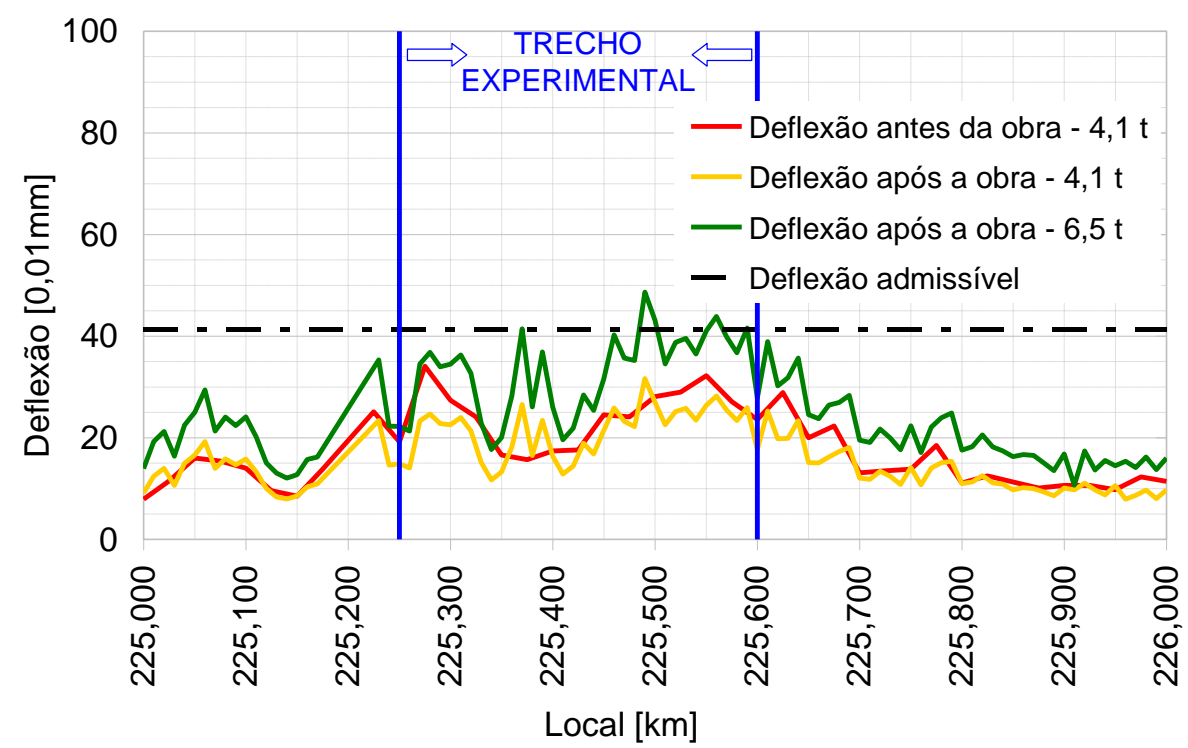

Figura 87 - Resultado de levantamento de deflexões com viga Benkelman antes e após oito meses da execução do trecho experimental

Verifica-se que as deflexões no $D_{0}$ antes e após a obra, no mesmo nível de carregamento $(4,1 \mathrm{t})$, mostraram um perfil de certa forma semelhante, demonstrando que não houve variação significativa deste parâmetro com a aplicação da mistura morna.

Mesmo quando o carregamento foi elevado a $6,5 \mathrm{t}$, grande parte das deflexões ainda se mostrou dentro do aceitável, onde os pontos acima do admissível 
neste nível mais elevado de carregamento se situavam em locais com a existência de drenos transversais.

\subsection{TRECHO EXPERIMENTAL COM MISTURAS MORNA E A QUENTE NA RODOVIA DOS BANDEIRANTES}

O segundo trecho experimental com mistura morna acompanhado nesta pesquisa foi realizado na Rodovia dos Bandeirantes. Esta é uma das principais rodovias do Estado de São Paulo e liga a capital a municípios do interior em uma extensão de 160 quilômetros.

A Rodovia dos Bandeirantes foi inaugurada em outubro de 1978, sendo então prolongada no final da década de 90 . A princípio, foi concebida para fazer a ligação entre as cidades de São Paulo e Campinas, como forma de desafogar o tráfego da Rodovia Anhanguera, que já se encontrava saturada. A primeira etapa de obra foi realizada pela Desenvolvimento Rodoviário S.A. (Dersa), sob um prazo que foi considerado recorde (26 meses). Já em 1998, o Grupo CCR assumiu a concessão do sistema Anhanguera-Bandeirantes e, por meio da AutoBAn, iniciou o prolongamento da Rodovia dos Bandeirantes até o município de Cordeirópolis, que foi entregue no final do ano 2001. Atualmente, a rodovia possui duas pistas de quatro faixas de tráfego cada uma de São Paulo a Jundiaí, de três faixas até o trevo de Santa Bárbara d'Oeste e de duas faixas após esse trevo, além de 174 obras de arte (entre viadutos, pontes e passagens inferiores e superiores) ${ }^{13}$.

Como a AutoBAn tinha um projeto de efetuar o recapeamento da Rodovia dos Bandeirantes no ano de 2011 com uma mistura asfáltica de graduação gap-graded e asfalto-borracha, a concessionária se programou para, em meados de 2010, executar um segmento-teste com $3 \mathrm{~cm}$ de espessura, ao longo de cerca de $7 \mathrm{~km}$, em três faixas de rolamento. Dentro deste contexto, houve a oportunidade de se fazer um trecho de cerca de $400 \mathrm{~m}$ em tal segmento, com a mesma mistura asfáltica, porém em temperatura morna. Desta maneira, com a mistura a quente sendo aplicada de modo contíguo à mistura morna, foi possível comparar a execução e o comportamento de ambas em usina e em pista. A Figura 88 apresenta um croqui

\footnotetext{
${ }^{13}$ Informações disponíveis em <www.autoban.com.br>. Acesso em 04 abr 2011.
} 
simplificado dos segmentos experimentais de mistura morna e a quente na Rodovia dos Bandeirantes que foram acompanhados na presente pesquisa.

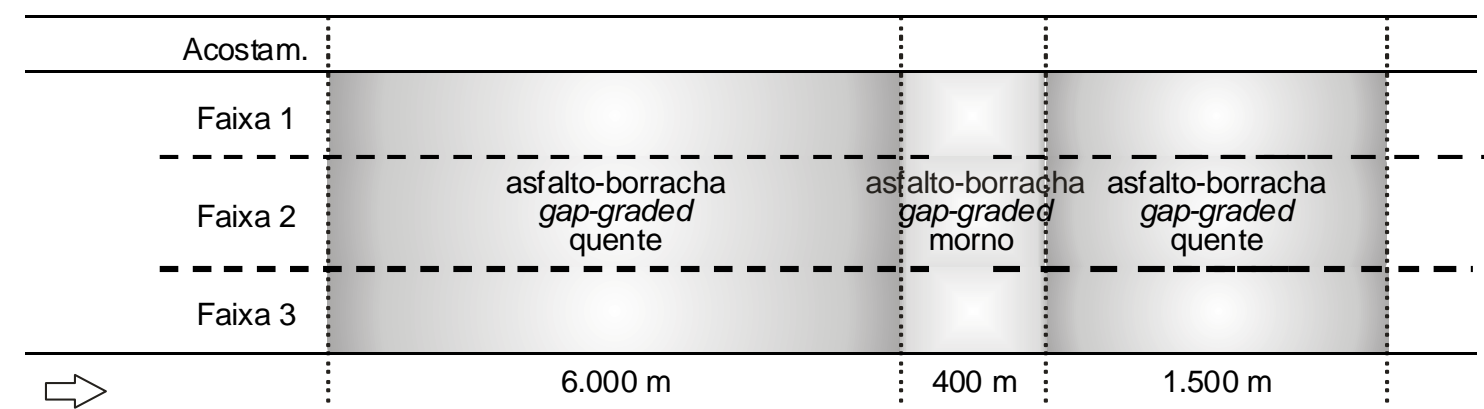

São Paulo

Figura 88 - Croqui dos trechos experimentais acompanhados nesta pesquisa na Rodovia dos Bandeirantes (distâncias aproximadas)

Toda a obra seria então executada na Rodovia dos Bandeirantes, pista sul (sentido São Paulo), na altura da cidade de Campinas (interior de São Paulo), que fica distante cerca de $80 \mathrm{~km}$ do centro da capital (Figura 89).

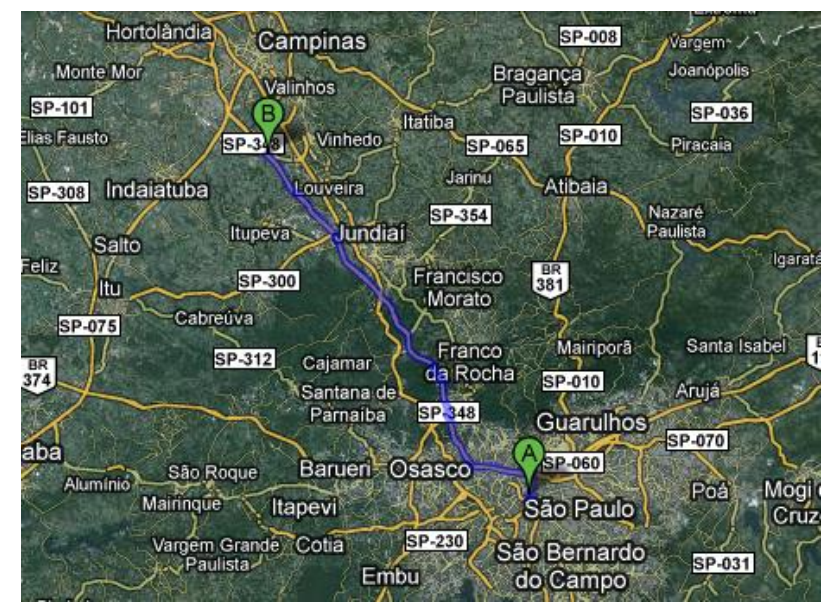

Figura 89 - Localização do trecho experimental na Rodovia dos Bandeirantes em Campinas, em relação a São Paulo

retirado de www.maps.google.com

Segundo informações da Secretaria de Logística e Transportes do Departamento de Estradas de Rodagem do Estado de São Paulo, o Volume Diário Médio (VDM) em 2009 na região próxima à localização do trecho experimental foi de 8.157 veículos comerciais e de 22.109 veículos de passeio ${ }^{14}$.

\footnotetext{
${ }^{14}$ Informação disponível em <http://www.der.sp.gov.br>. Acesso em: 04 abr. 2011.
} 


\subsubsection{Projetos das misturas a quente e morna}

As misturas asfálticas a quente e morna que seriam utilizadas na obra da Rodovia dos Bandeirantes correspondem, respectivamente, à HMA3 e à WMA3 estudadas em laboratório, constituídas basicamente de agregados com graduação gap-graded 3/8" (Caltrans) e com asfalto-borracha tipo AB-22 (20\% de borracha). De modo resumido, a Tabela 33 aponta o traço e as temperaturas indicados para as situações de campo com ambas as misturas asfálticas.

Tabela 33 - Traço e temperaturas indicados para a produção e aplicação das misturas asfálticas dos trechos experimentais da Rodovia dos Bandeirantes

\begin{tabular}{cccc} 
& & $\begin{array}{c}\text { Mistura } \\
\text { a quente }\end{array}$ & $\begin{array}{c}\text { Mistura } \\
\text { morna }\end{array}$ \\
\hline \multirow{2}{c}{ Ligante asfáltico } & $6,5 \%$ asfalto-borracha* & $\begin{array}{c}6,5 \% \text { asfalto-borracha } \\
\text { com 0,4\% de Gemul XT14** }\end{array}$ \\
\hline \multirow{2}{*}{$\begin{array}{c}\text { Agregados } \\
{[\%]}\end{array}$} & Pedrisco & 66 & 66 \\
\cline { 2 - 4 } & Pó-de-pedra & 32,5 & 32,5 \\
\hline \multirow{2}{*}{$\begin{array}{c}\text { Temperatura } \\
{\left[{ }^{\circ} \mathrm{C}\right]}\end{array}$} & Cal CH-I & 1,5 & 1,5 \\
\cline { 2 - 4 } & Ligante & $175-180$ & $175-180$ \\
\cline { 2 - 4 } & Usinados & $180-185$ & $145-150$ \\
\cline { 2 - 4 } & Compactação & $175-180$ & $150-145$ \\
\hline
\end{tabular}

* Asfalto-borracha comercializado pelo fornecedor de asfalto sob a denominação Ecoflex $A$

** Asfalto-borracha com aditivo para mistura morna comercializado pelo fornecedor de asfalto sob a denominação Ecoflex A com G-WMIX

A incorporação do Gemul XT14 ao ligante foi feita no fornecedor de asfalto, sendo o produto adicionado na carreta antes da saída para a usina, conforme ilustrado na Figura 90. Neste caso, a agitação do veículo ao longo do trajeto já iniciaria o processo de mistura do aditivo com o ligante, antes do descarregamento no tanque de asfalto da usina. 

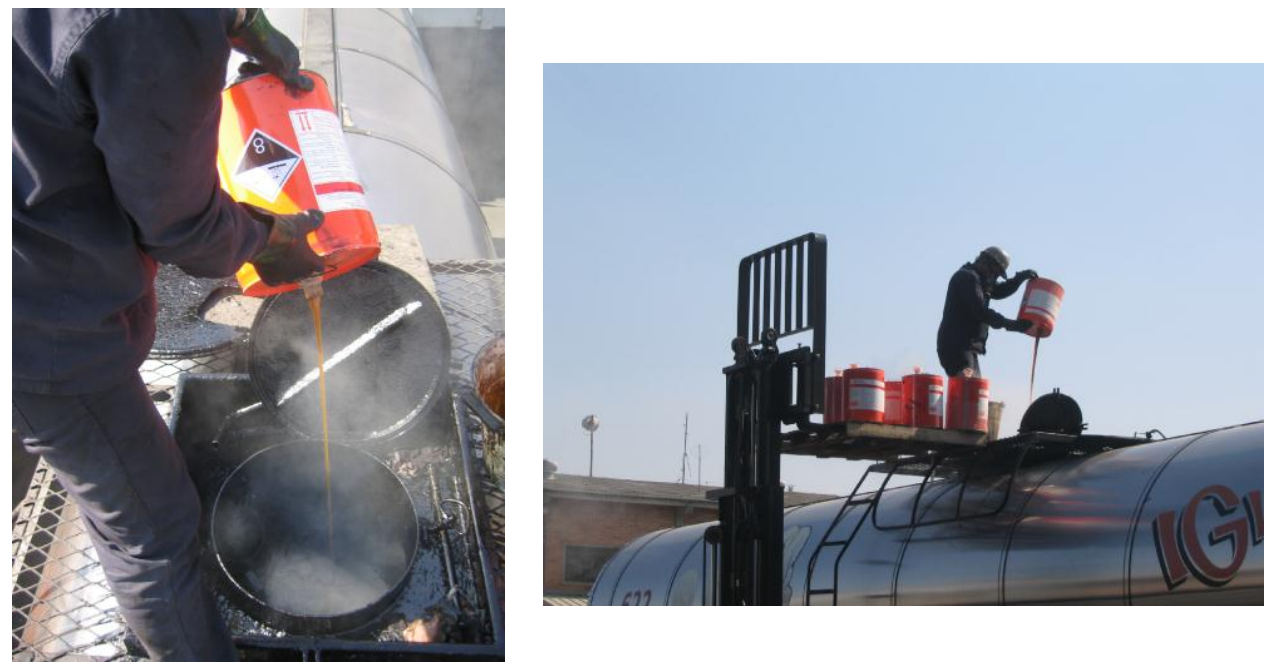

Figura 90 - Incorporação do aditivo para mistura morna à carreta de asfalto

\subsubsection{Produção em usina e aplicação das misturas a quente e morna em pista}

A usina de asfalto responsável por produzir as misturas asfálticas estava localizada na Pedreira Basalto 6, pertencente ao Grupo Estrutural, sendo do tipo gravimétrica.

O primeiro segmento, constituído de mistura asfáltica a quente, foi iniciado em julho de 2010, a partir do km 85+600, com duração aproximada de três semanas. Em seguida, o trecho com mistura morna foi executado entre o km 79+560 e o $79+170$, entre os dias 24 e 26 de agosto. Por fim, a obra foi finalizada com o uso novamente da mistura a quente até o km 78+140, entre os dias 01 e 02 de setembro.

Para a pavimentação destes segmentos foram produzidas mais de 5.700 toneladas de mistura a quente e cerca de 450 toneladas de mistura morna, segundo as planilhas de controle de usina. Do montante destes materiais, uma parte foi enviada ao LTP/EPUSP para ensaios posteriores.

Além disso, tal controle indicou que as temperaturas verificadas nos caminhões recém-carregados em usina variaram entre 170 e $180^{\circ} \mathrm{C}$ na mistura a quente, e entre 140 e $150^{\circ} \mathrm{C}$ na mistura morna. Particularmente no caso da mistura morna, os agregados aparentavam estar bem envolvidos pelo ligante (Figura 91), mesmo a usinagem tendo sido efetuada em temperaturas desta ordem de grandeza. 


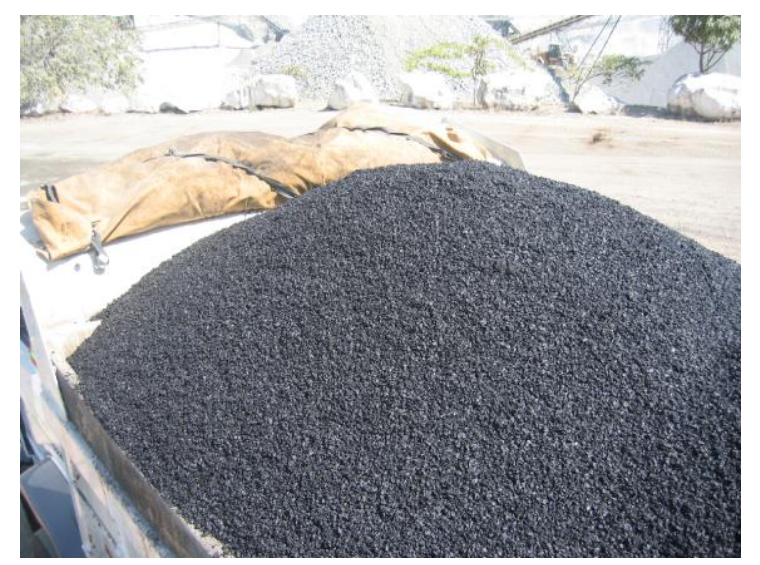

Figura 91 - Aspecto, no caminhão, da mistura morna usinada para o trecho experimental da Rodovia dos Bandeirantes

A Figura 92 e a Figura 93 ilustram, respectivamente, o lançamento e a compactação da mistura morna em pista na Rodovia dos Bandeirantes. Segundo as planilhas de controle de obra, a temperatura na vibroacabadora durante 0 espalhamento do material para a compactação variou entre 155 e $175^{\circ} \mathrm{C}$ na mistura a quente e entre 130 e $145^{\circ} \mathrm{C}$ na mistura morna.

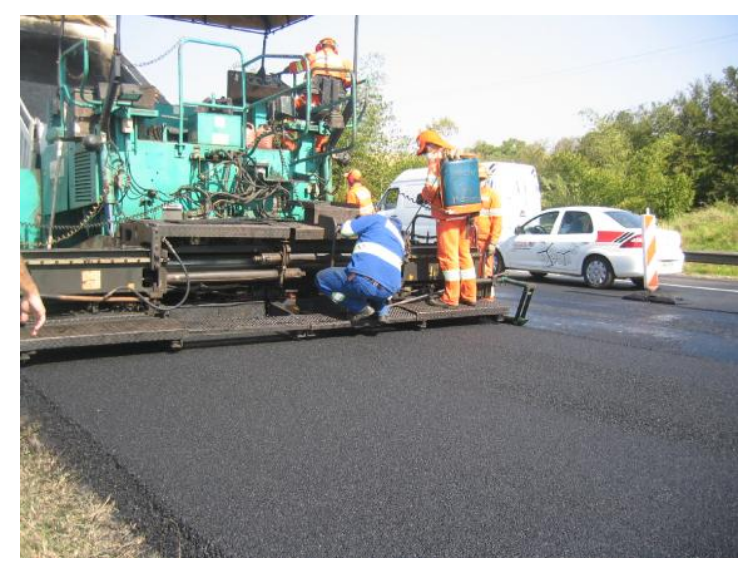

Figura 92 - Espalhamento da mistura morna em pista na Rodovia dos Bandeirantes

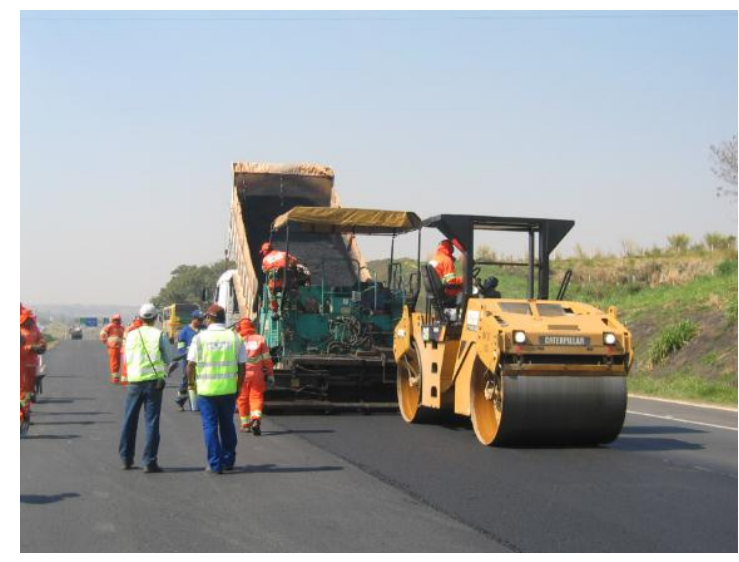

Figura 93 - Compactação da mistura morna em pista na Rodovia dos Bandeirantes 
Por fim, a Figura 94 apresenta o aspecto final do pavimento revestido com a mistura morna.

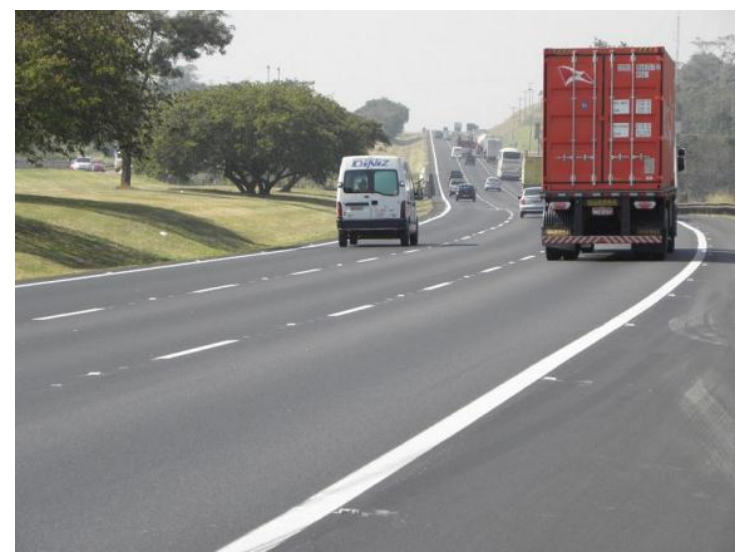

Figura 94 - Trecho experimental de mistura morna já executado na Rodovia dos Bandeirantes Foto: Décio de Souza

\subsubsection{Controle tecnológico de compactação e espessura}

A concessionária AutoBAn forneceu os dados do controle de compactação e espessura obtidos com CPs extraídos de pista, ao longo da execução das obras. Os ensaios de controle de compactação e a verificação da espessura foram realizados no laboratório da Basalto/Estrutural. O nível de compactação foi determinado por VV, através de pesagem hidrostática dos CPs de campo (como descrito no item 3.5.1.1) e determinação da MEMT de cada mistura asfáltica (método RICE, segundo AASHTO T209-99). A Tabela 34 apresenta os resultados médios obtidos.

Tabela 34 - Controle de compactação e espessura dos trechos experimentais na Rodovia dos Bandeirantes

\begin{tabular}{ccccc}
\hline Segmento & $\begin{array}{c}\text { Número } \\
\text { de CPs }\end{array}$ & $\begin{array}{c}\text { Grau de compactação } \\
{[\%]}\end{array}$ & $\begin{array}{c}\text { Volume de vazios } \\
{[\%]}\end{array}$ & $\begin{array}{c}\text { Espessura } \\
{[\mathrm{cm}]}\end{array}$ \\
\hline Mistura a quente & 145 & $98,6( \pm 0,6)$ & $6,1( \pm 0,8)$ & $3,5( \pm 0,5)$ \\
\hline Mistura morna & 16 & $99,2( \pm 0,4)$ & $5,9( \pm 0,5)$ & $3,9( \pm 0,4)$ \\
\hline
\end{tabular}

Com relação ao grau de compactação, a norma DNIT ES112/09 determina que este deve se situar entre 97 e 101\%. Com isto, nota-se que ambas as misturas se enquadraram neste item da especificação. Já segundo as especificações de projeto, o VV deveria se situar abaixo de $7,5 \%$, enquanto a camada deveria ter uma espessura superior a $2,9 \mathrm{~cm}$. Deste modo, constatou-se que ambas as misturas 
atenderam tais limites, levando o trecho a ser aprovado por compactação e espessura.

De modo complementar, foi feita ainda uma análise de variância dos resultados de grau de compactação, volume de vazios e espessura, comparando-se os segmentos de mistura a quente e morna. Os resultados indicaram que o VV de ambas as misturas eram estatisticamente iguais, embora o grau de compactação e a espessura da mistura a quente tenham sido considerados estatisticamente diferentes daqueles da mistura morna.

\subsubsection{Ensaios laboratoriais de propriedades mecânicas e testes complementares com as misturas a quente e morna de usina}

A Figura 95 aponta um resumo esquemático dos ensaios de propriedades mecânicas e testes complementares com as misturas a quente e morna provenientes de usina, que foram empregadas na Rodovia dos Bandeirantes.

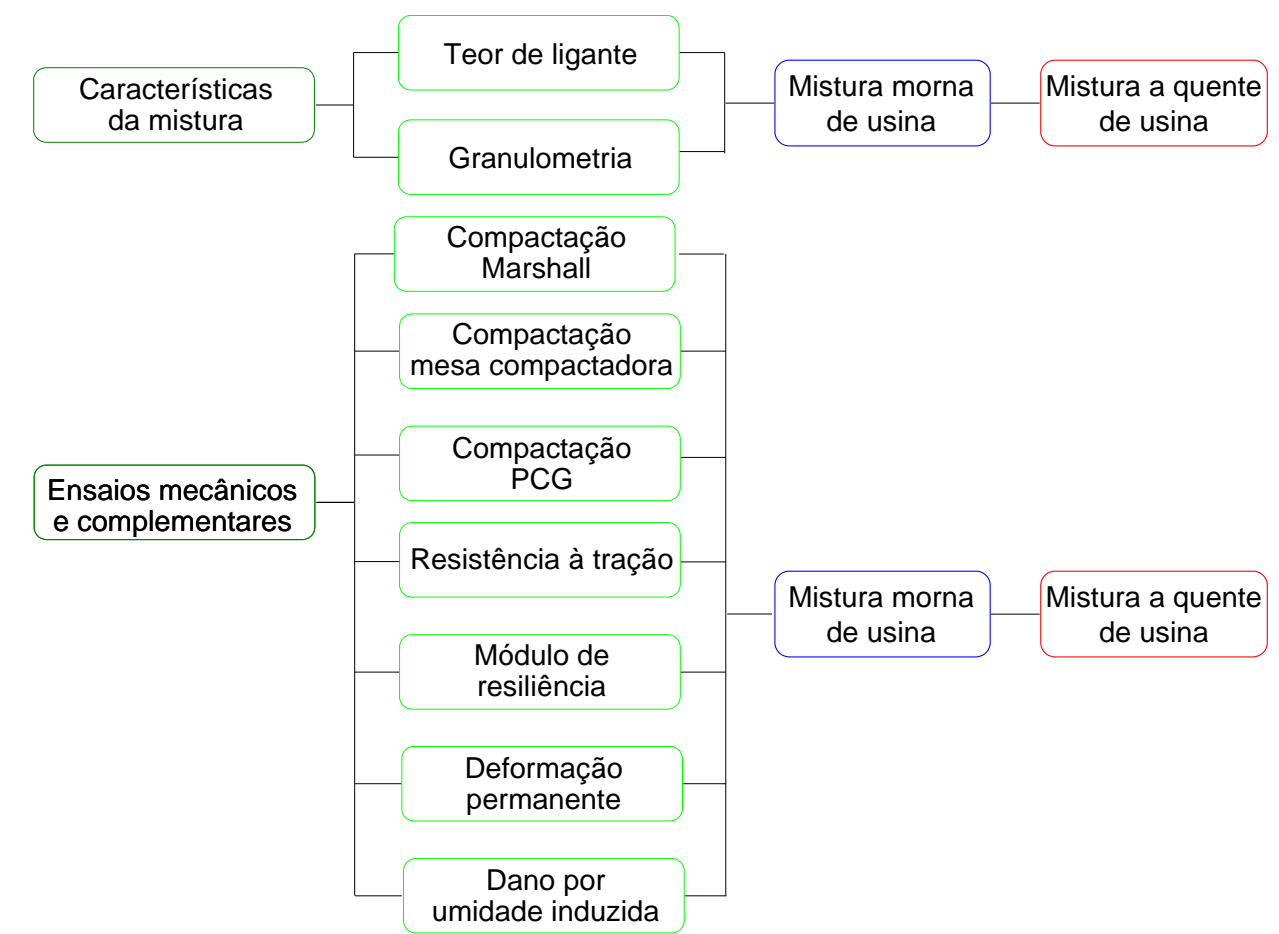

Figura 95 - Resumo dos ensaios dos ensaios de propriedades mecânicas e testes complementares com as misturas a quente e morna de usina empregadas no trecho experimental da Rodovia dos Bandeirantes 
Para a moldagem dos CPs, as misturas a quente e morna foram reaquecidas às temperaturas de $170^{\circ} \mathrm{C}$ e $140^{\circ} \mathrm{C}$, respectivamente (temperaturas utilizadas para a compactação em laboratório e próximas às médias empregadas em campo).

Nos próximos itens são apresentados os resultados obtidos nos ensaios com as misturas a quente e morna de usina e, sempre que possível, também há a indicação dos valores encontrados com as misturas de laboratório, para fins de comparação.

\subsubsection{Características dos materiais das misturas a quente e morna de usina}

Durante as obras da Rodovia dos Bandeirantes, o laboratório da Basalto 6/Estrutural realizou uma série de testes de extração e recuperação do ligante das misturas asfálticas produzidas, a fim de conferir o teor de asfalto e a granulometria de cada amostra, utilizando forno de extração de betume (Figura 96).

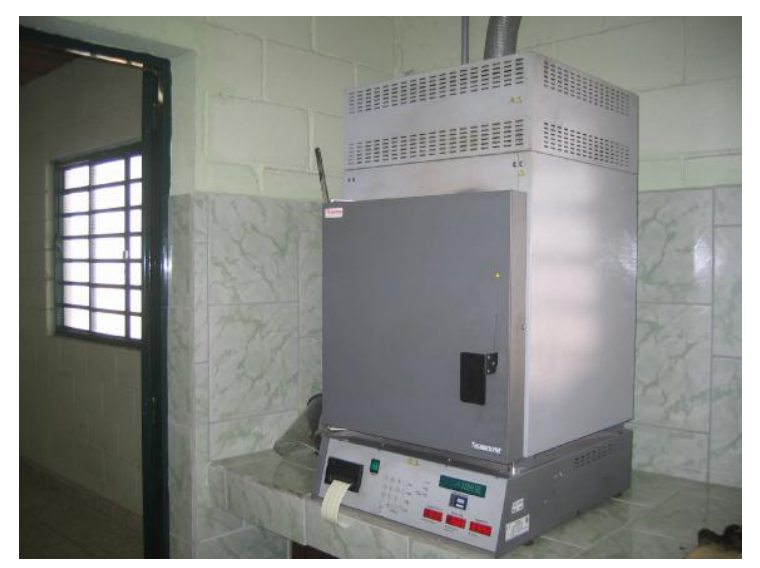

Figura 96 - Forno de extração de betume do laboratório da Basalto 6/Estrutural

Da mesma maneira, as misturas a quente e morna enviadas ao LTP/EPUSP também foram submetidas à extração e recuperação do ligante, porém pelo método Abson (ASTM D1856-95), no laboratório da empresa Imperpav Projetos e Consultoria Ltda (o mesmo que efetuou este teste com o material de usina do primeiro trecho experimental). Neste caso, ainda havia a intenção de realizar ensaios de penetração e ponto de amolecimento com o ligante extraído para verificar a mudança de consistência (penetração e ponto de amolecimento), devido ao envelhecimento na usinagem. Como se tratava de um asfalto-borracha, a 
extração e recuperação do ligante foi mais difícil que a de um asfalto convencional. No mais, após a separação dos componentes das misturas asfálticas, notou-se que pequenas partículas ainda ficaram remanescentes por sobre os agregados recuperados (Figura 97), que se acreditou ser negro de fumo do asfalto. Dentro deste contexto, optou-se por desistir dos ensaios de consistência, pois estes poderiam indicar valores errôneos, devido àquela perda de componentes do ligante avaliado.

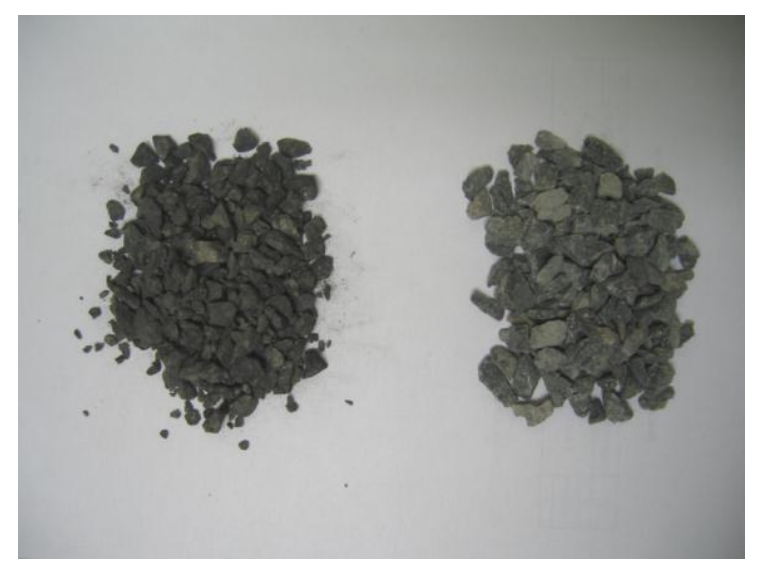

Figura 97 - Aparência dos agregados recuperados pelo método Abson, com partículas aderidas (à esquerda) e dos agregados virgens (à direita)

\section{$\underline{\text { Teor de ligante }}$}

Para a determinação do teor de ligante das misturas asfálticas de usina foram testadas 22 amostras de mistura a quente e 3 amostras de mistura morna no forno de extração de betume do laboratório da Basalto/Estrutural. A quantidade média de asfalto encontrada nas misturas a quente foi de $6,5 \%( \pm 0,2 \%)$, enquanto nas misturas mornas foi de $6,4 \%( \pm 0,1 \%)$.

Já no caso da extração e recuperação pelo método Abson, as amostras de misturas a quente e morna de usina foram divididas cada uma em seis partes para a obtenção do teor de ligante. Os resultados mostraram que a porcentagem média de asfalto na mistura a quente foi de $6,0 \%( \pm 0,2 \%)$, enquanto na mistura morna foi de $6,2 \%( \pm 0,2 \%)$. Deve-se considerar que neste método 0 valor pode estar subestimado em função da perda de componentes do ligante, conforme mencionado anteriormente. 
Considerando-se então que o teor de asfalto indicado para a preparação das misturas asfálticas foi de 6,5\%, sendo aceitável uma variação em usina entre 6,2 a $6,8 \%$ ( $\pm 0,3 \%)$, concluiu-se que os valores médios obtidos pelo forno de extração de betume se enquadraram dentro do tolerável. Já aqueles encontrados pelo método Abson seriam aceitáveis somente no caso da mistura morna, mas no limite mínimo. Deste modo, deve-se atentar para a diferença de resultados em função da metodologia empregada, quando do controle tecnológico do teor de ligante da mistura asfáltica.

\section{Granulometria}

Para a determinação da curva granulométrica das misturas asfálticas preparadas em usina foram testadas 11 amostras de mistura a quente e 3 amostras de mistura morna no laboratório da Basalto/Estrutural. A partir do peneiramento dos agregados recuperados, verificou-se que todas as misturas apresentaram granulometria com enquadramento dentro da faixa de trabalho indicada no projeto. A Figura 98 exemplifica um dos resultados obtidos com cada uma das misturas asfálticas.

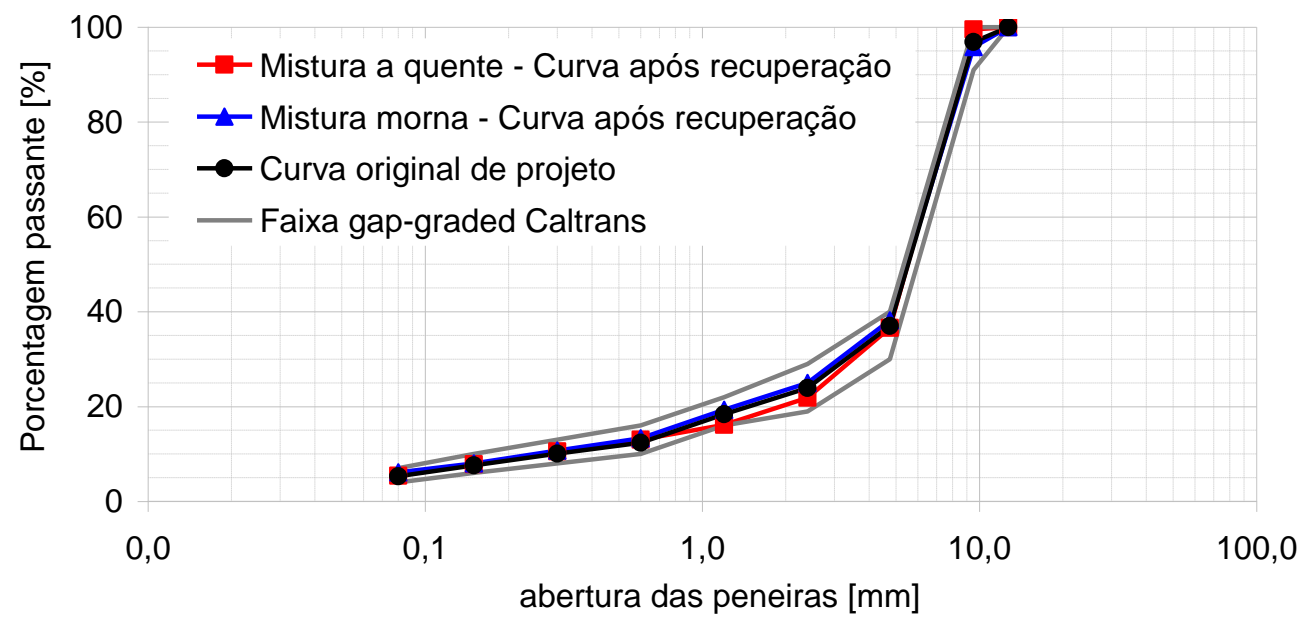

Figura 98 - Curva granulométrica após extração de ligante e recuperação 


\subsection{Marshall}

A compactação Marshall foi realizada segundo descrito no item 3.5.1.1. O resultado do VV médio é apresentado na Figura 99 (juntamente com os valores dos CPs extraídos de pista por ocasião do controle tecnológico e das misturas de laboratório).

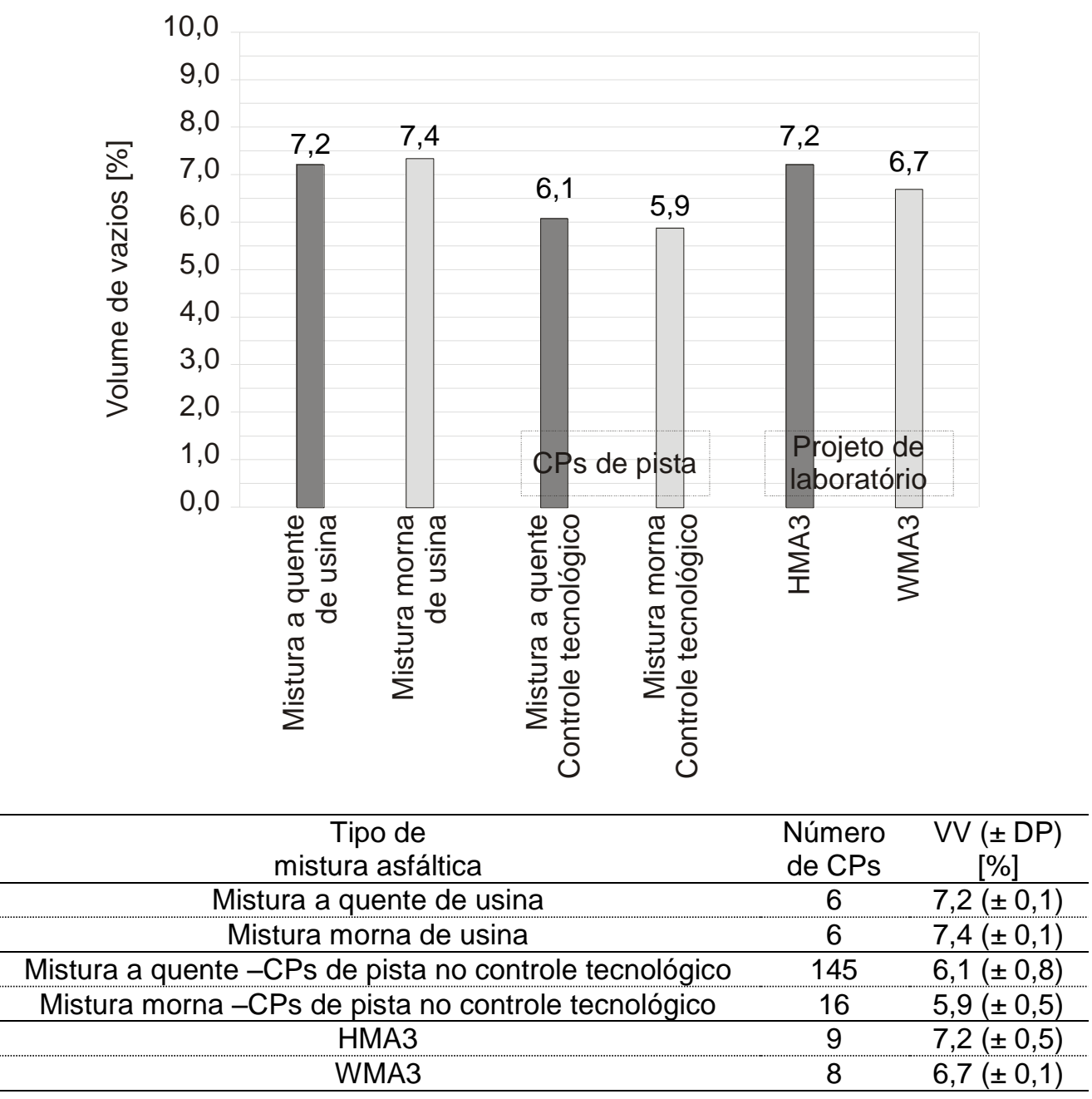

Figura 99 - Compactação Marshall das misturas a quente e morna de usina, em comparação com os corpos de prova extraídos de pista e com as misturas de laboratório

De modo complementar, foram realizadas análises de variância do VV, comparando-se os resultados da mistura a quente com os da mistura morna. Os resultados são apresentados na Tabela 35. 
Tabela 35 - Análise de variância do volume de vazios das misturas a quente e morna relativas aos trechos experimentais da Rodovia dos Bandeirantes

\begin{tabular}{cccc}
\hline Tipo de mistura asfáltica & Mistura a quente de usina & Mistura a quente - CPs pista & HMA3 \\
\hline Mistura morna de usina & ED & -- & -- \\
\hline Mistura morna -CPs pista & -- & ED & -- \\
\hline WMA3 & -- & -- & El \\
\hline
\end{tabular}

Embora apresentando valores muito próximos, as misturas a quente e morna de usina foram consideradas estatisticamente diferentes, devido à pequena variabilidade de VV dentro de cada tipo de mistura asfáltica. Mas pode-se dizer que os valores são semelhantes e que o comportamento destas misturas quanto à compactação Marshall foi análogo.

No mais, as misturas de usina apresentaram VV de mesma ordem de grandeza que o daquelas de laboratório, devendo-se considerar que todas estas misturas asfálticas foram compactadas no mesmo local.

No geral, verificou-se que a compactação destas misturas com graduação semidescontínua com ligante modificado pareceu ser mais difícil que àquelas de graduação densa e asfalto convencional, conforme já comentado no item 3.6.1.

\subsection{Mesa compactadora}

A compactação em mesa compactadora foi realizada conforme descrito no item 3.5.1.2, moldando-se uma placa de cada tipo de mistura asfáltica (a quente e morna) de usina. Em seguida, as placas tiveram as bordas eliminadas e foram submetidas à pesagem hidrostática (AASHTO T166-07). A Figura 100 apresenta o resultado encontrado (juntamente com aqueles das misturas de laboratório). 


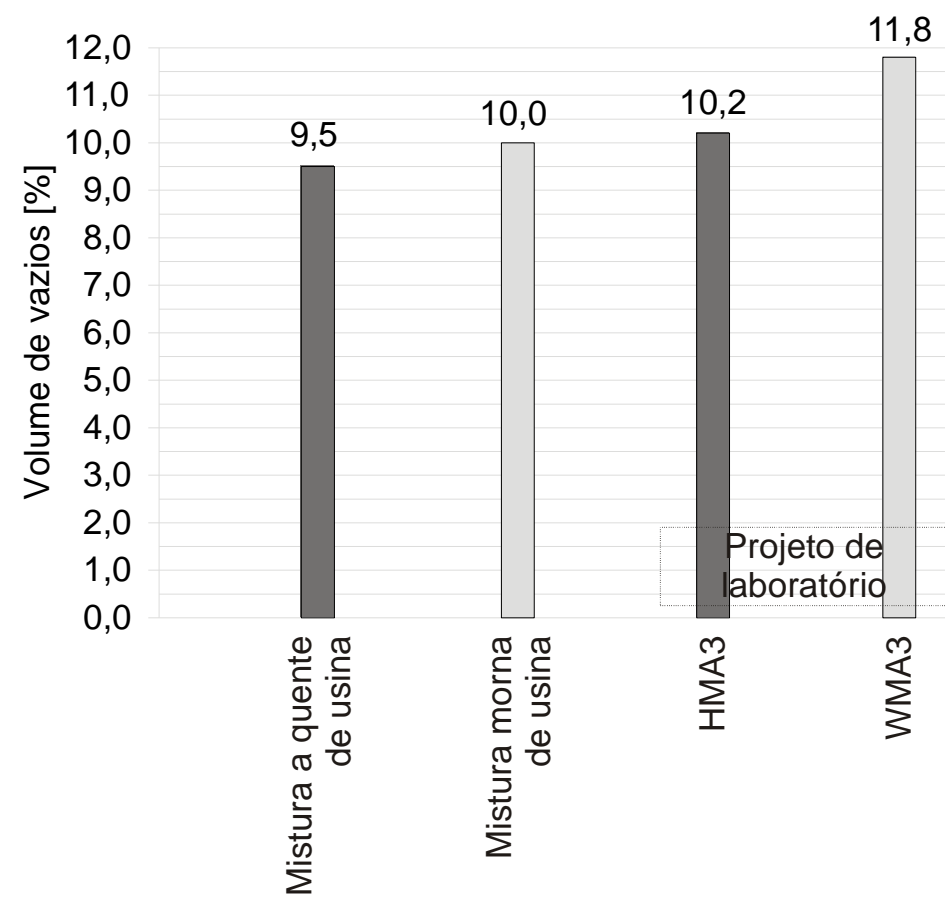

Figura 100 - Compactação em mesa compactadora com as misturas a quente e morna de usina, em comparação com as misturas de laboratório

Seguindo a mesma tendência das misturas de laboratório, as misturas de usina também demonstraram dificuldade de compactação na mesa compactadora, conforme comentado no item 3.6.1.4. Porém, como será mencionado no item 4.2.4.5, este tipo de mistura asfáltica (com descontinuidade na granulometria) requer ser compactada por rolagem em menores temperaturas que aquelas indicadas usualmente, para que a densificação seja eficiente e tais VV sejam menores.

De qualquer modo, de acordo com a norma EN 13108-2/06, as misturas asfálticas BBTM 10B devem conter um VV de 9 a $16 \%$ em placas com $5 \mathrm{~cm}$ de espessura. Fazendo-se então a comparação dos resultados obtidos com a especificação europeia, (ainda que isto seja uma aproximação), verifica-se que os valores encontrados se situaram dentro de tais recomendações.

\subsection{Prensa de cisalhamento giratório}

O ensaio na PCG foi realizado conforme descrito no item 3.5.1.3. A partir dos dados volumétricos indicados pelo equipamento, e da pesagem hidrostática dos CPs moldados (AASHTO T166-07), foi possível corrigir o VV e plotar a curva média VV $x$ Giros, indicada na Figura 101. 


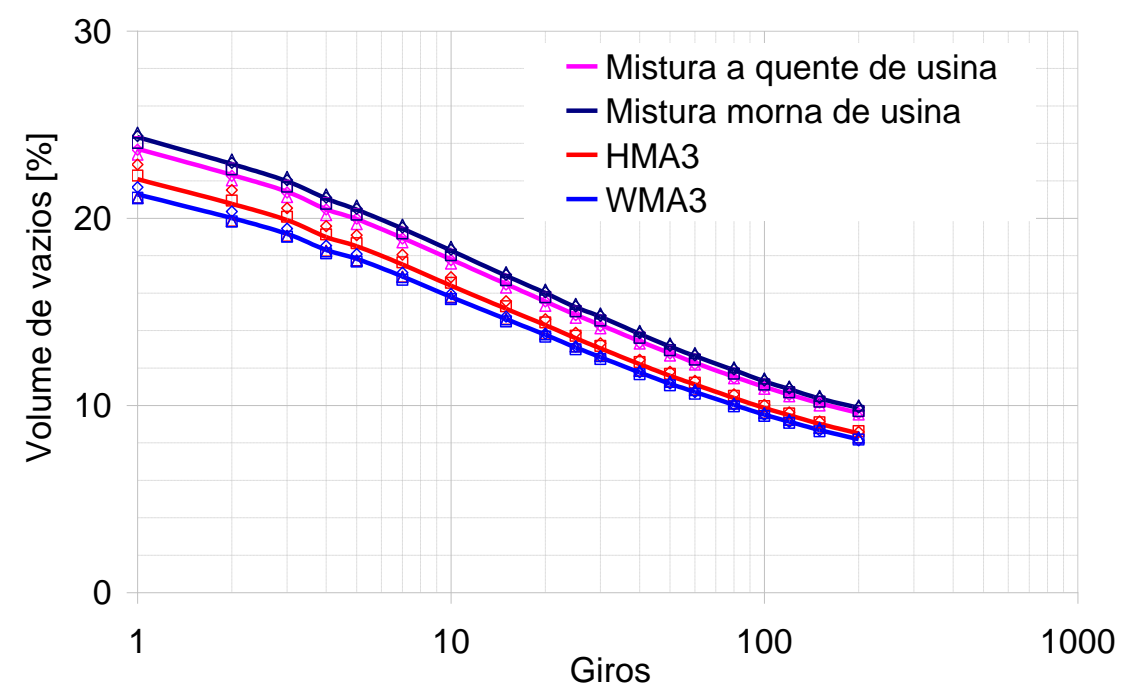

\begin{tabular}{ccccc}
\cline { 2 - 5 } Giros & $\begin{array}{c}\text { Vistura a quente }( \pm \mathrm{DP})[\%] \\
\text { de usina }\end{array}$ & $\begin{array}{c}\text { Mistura morna } \\
\text { de usina }\end{array}$ & HMA3 & WMA3 \\
\hline 1 & $23,7( \pm 0,3)$ & $24,3( \pm 0,3)$ & $22,1( \pm 0,9)$ & $21,3( \pm 0,3)$ \\
\hline 2 & $22,3( \pm 0,3)$ & $22,9( \pm 0,3)$ & $20,8( \pm 0,8)$ & $20,0( \pm 0,3)$ \\
\hline 3 & $21,4( \pm 0,3)$ & $22,0( \pm 0,3)$ & $19,9( \pm 0,8)$ & $19,2( \pm 0,2)$ \\
4 & $20,5( \pm 0,3)$ & $21,1( \pm 0,3)$ & $19,0( \pm 0,7)$ & $18,3( \pm 0,2)$ \\
5 & $20,0( \pm 0,3)$ & $20,5( \pm 0,2)$ & $18,5( \pm 0,7)$ & $17,8( \pm 0,2)$ \\
\hline 7 & $18,9( \pm 0,3)$ & $19,5( \pm 0,2)$ & $17,5( \pm 0,6)$ & $16,9( \pm 0,2)$ \\
10 & $17,8( \pm 0,2)$ & $18,3( \pm 0,2)$ & $16,4( \pm 0,5)$ & $15,8( \pm 0,1)$ \\
15 & $16,5( \pm 0,2)$ & $16,9( \pm 0,2)$ & $15,2( \pm 0,5)$ & $14,6( \pm 0,1)$ \\
\hline 20 & $15,6( \pm 0,2)$ & $16,0( \pm 0,2)$ & $14,3( \pm 0,4)$ & $13,8( \pm 0,1)$ \\
\hline 25 & $14,8( \pm 0,2)$ & $15,2( \pm 0,2)$ & $13,6( \pm 0,4)$ & $13,1( \pm 0,1)$ \\
\hline 30 & $14,3( \pm 0,2)$ & $14,7( \pm 0,2)$ & $13,1( \pm 0,3)$ & $12,6( \pm 0,1)$ \\
\hline 40 & $13,4( \pm 0,2)$ & $13,8( \pm 0,2)$ & $12,2( \pm 0,3)$ & $11,8( \pm 0,1)$ \\
\hline 50 & $12,8( \pm 0,1)$ & $13,1( \pm 0,2)$ & $11,6( \pm 0,3)$ & $11,2( \pm 0,1)$ \\
60 & $12,3( \pm 0,1)$ & $12,6( \pm 0,2)$ & $11,1( \pm 0,2)$ & $10,7( \pm 0,1)$ \\
\hline 0 & $11,5( \pm 0,1)$ & $11,9( \pm 0,2)$ & $10,4( \pm 0,3)$ & $10,0( \pm 0,1)$ \\
\hline 100 & $11,0( \pm 0,1)$ & $11,3( \pm 0,2)$ & $9,9( \pm 0,2)$ & $9,5( \pm 0,1)$ \\
\hline 120 & $10,6( \pm 0,1)$ & $10,9( \pm 0,2)$ & $9,5( \pm 0,2)$ & $9,1( \pm 0,1)$ \\
\hline 150 & $10,1( \pm 0,1)$ & $10,4( \pm 0,2)$ & $9,0( \pm 0,2)$ & $8,7( \pm 0,1)$ \\
\hline 200 & $9,6( \pm 0,1)$ & $9,9( \pm 0,2)$ & $8,5( \pm 0,2)$ & $8,2( \pm 0,1)$ \\
\hline
\end{tabular}

Figura 101 - Evolução da compactação na prensa de cisalhamento giratório das misturas a quente e morna preparadas em usina, em comparação com as misturas de laboratório

Nota-se que as misturas a quente e morna de usina apresentaram comportamento muito similar durante o ensaio na PCG, podendo-se dizer que ambas tiveram a mesma habilidade de compactação neste tipo equipamento. Todavia, deve-se levar em conta que a prensa giratória não tem se mostrado apropriada para diferenciar o comportamento de misturas asfálticas em função da temperatura, conforme comentado por Maillard-Nunes et al. (2009) e Huner e Brown (2001). 
O ensaio para determinação da RT foi realizado conforme descrito no item 3.5.2. A Figura 102 apresenta os valores médios de RT, bem como os de VV médio das misturas a quente e morna de usina (juntamente com os resultados das misturas de laboratório).

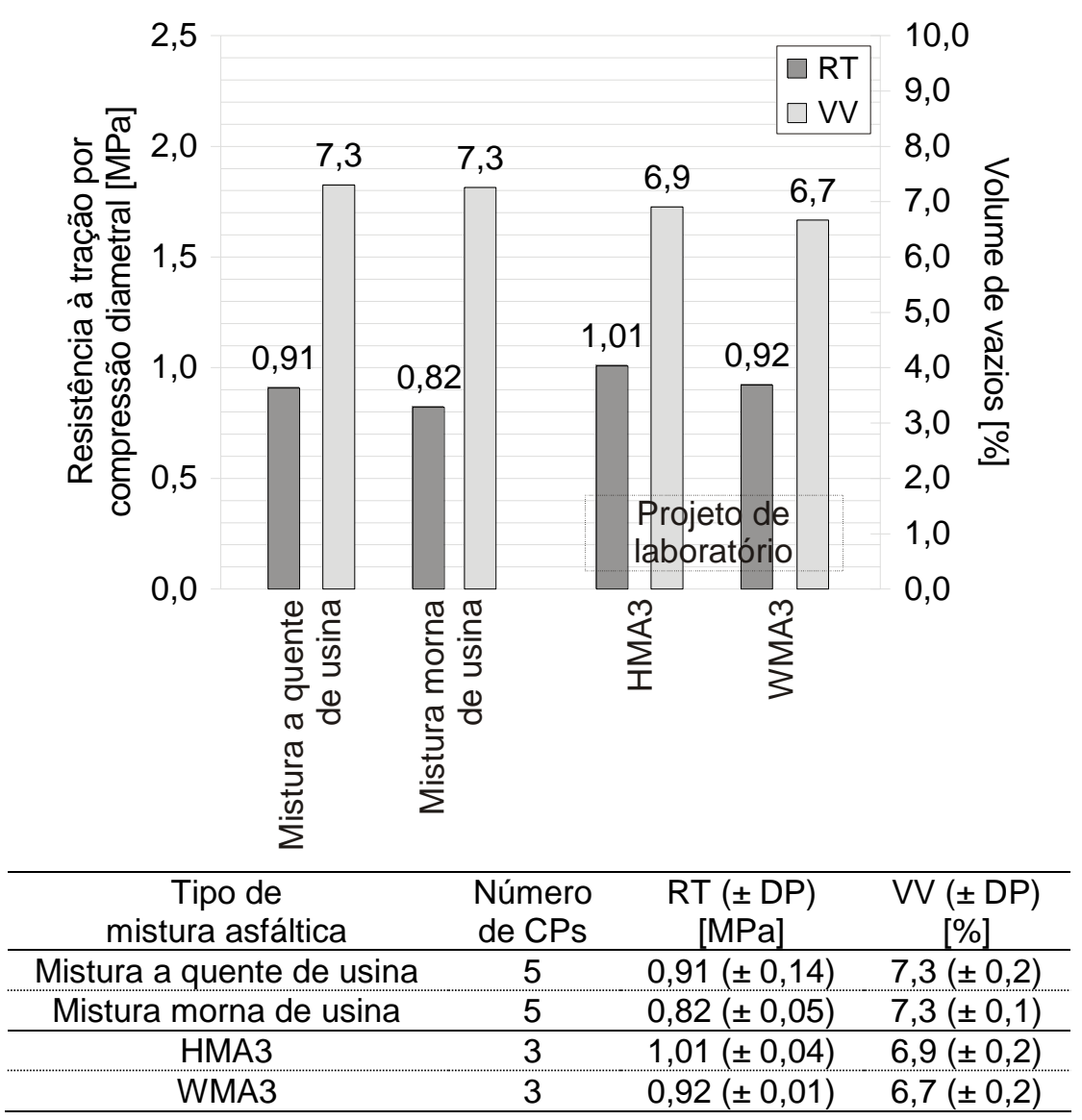

Figura 102 - Resistência à tração das misturas a quente e morna de usina, em comparação com as misturas de laboratório

A análise de variância dos resultados de misturas a quente e morna de usina mostrou que tanto a RT quanto o VV destes materiais são considerados estatisticamente iguais. Ou seja, a mistura morna apresentou comportamento semelhante à RT da mistura a quente, sob mesma condição de VV. No mais, ainda que os valores de usina estejam ligeiramente abaixo daqueles de laboratório, os mesmos podem ser considerados semelhantes, devido à proximidade de resultados. 
Por fim, considerando-se que a norma DNIT ES112/09 determina que a RT mínima de misturas gap-graded com asfalto-borracha deva ser de 0,50 MPa, verificou-se que as misturas de usina se enquadraram nesta especificação.

\subsubsection{Módulo de resiliência das misturas a quente e morna de usina}

O ensaio para determinação do MR foi realizado conforme descrito no item 3.5.3. A Figura 103 apresenta os valores médios de MR, bem como os de VV médio das misturas a quente e morna de usina (juntamente com os resultados das misturas de laboratório).

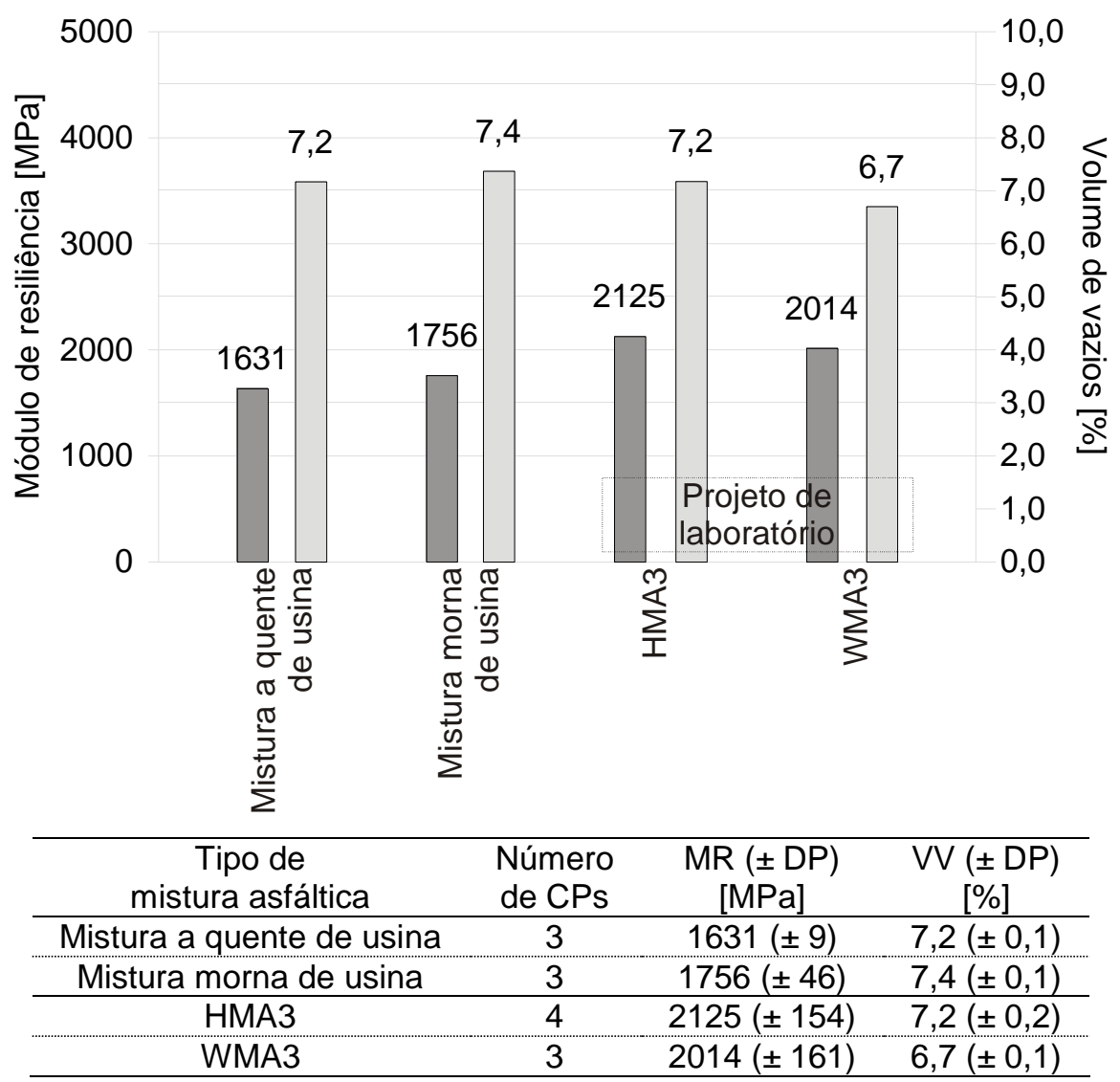

Figura 103 - Módulo de resiliência das misturas a quente e morna de usina, em comparação com as misturas preparadas em laboratório

Considerando-se inicialmente a situação de materiais produzidos em usina, a análise de variância da mistura a quente em relação à morna mostrou que os valores de VV de ambas foram considerados estatisticamente iguais, enquanto os resultados de MR foram tidos como diferentes. Na verdade, nota-se que esta 
diferença é pequena (125 MPa), sabendo-se que a ordem de grandeza do MR de misturas asfálticas é de 2.000 a $8.000 \mathrm{MPa}$ (BERNUCCl et al., 2008), mas como há pouca variabilidade em torno das médias, os valores de MR de ambas as misturas acabam sendo considerados diferentes.

\subsubsection{Deformação permanente das misturas a quente e morna de usina}

Para o ensaio de deformação permanente foi moldada uma placa com cada mistura produzida em usina (a quente e morna), conforme descrito no item 3.5.1.2. Do mesmo modo que foi observado com as misturas de laboratório, houve certa dificuldade de densificação deste tipo de mistura asfáltica por rolagem. Dentro deste contexto, alguns outros testes no LTP/EPUSP também demonstraram que, nestes casos (misturas com descontinuidade), é necessário aguardar até que a temperatura seja reduzida significativamente $\left(30\right.$ a $\left.40^{\circ} \mathrm{C}\right)$, imediatamente antes da compactação, para que esta ocorra de maneira eficiente. Com isto, para esta pesquisa foi ainda moldada uma placa extra com diminuição de temperatura de densificação $\left(45^{\circ} \mathrm{C}\right.$ na mistura a quente e $25^{\circ} \mathrm{C}$ na mistura morna), quando se verificou que, de fato, a habilidade para acomodar as misturas no molde foi maior. Neste caso, haveria impacto positivo na questão da deformação permanente, uma vez que a compactação mais eficiente diminuiria o VV e, por conseqüência, o potencial para a formação de afundamentos.

As placas foram submetidas ao simulador de tráfego, segundo procedimentos relatados no item 3.5.4, onde o resultado médio da evolução do afundamento em trilha de roda é apresentado na Figura 104, juntamente com os valores das misturas de laboratório. 


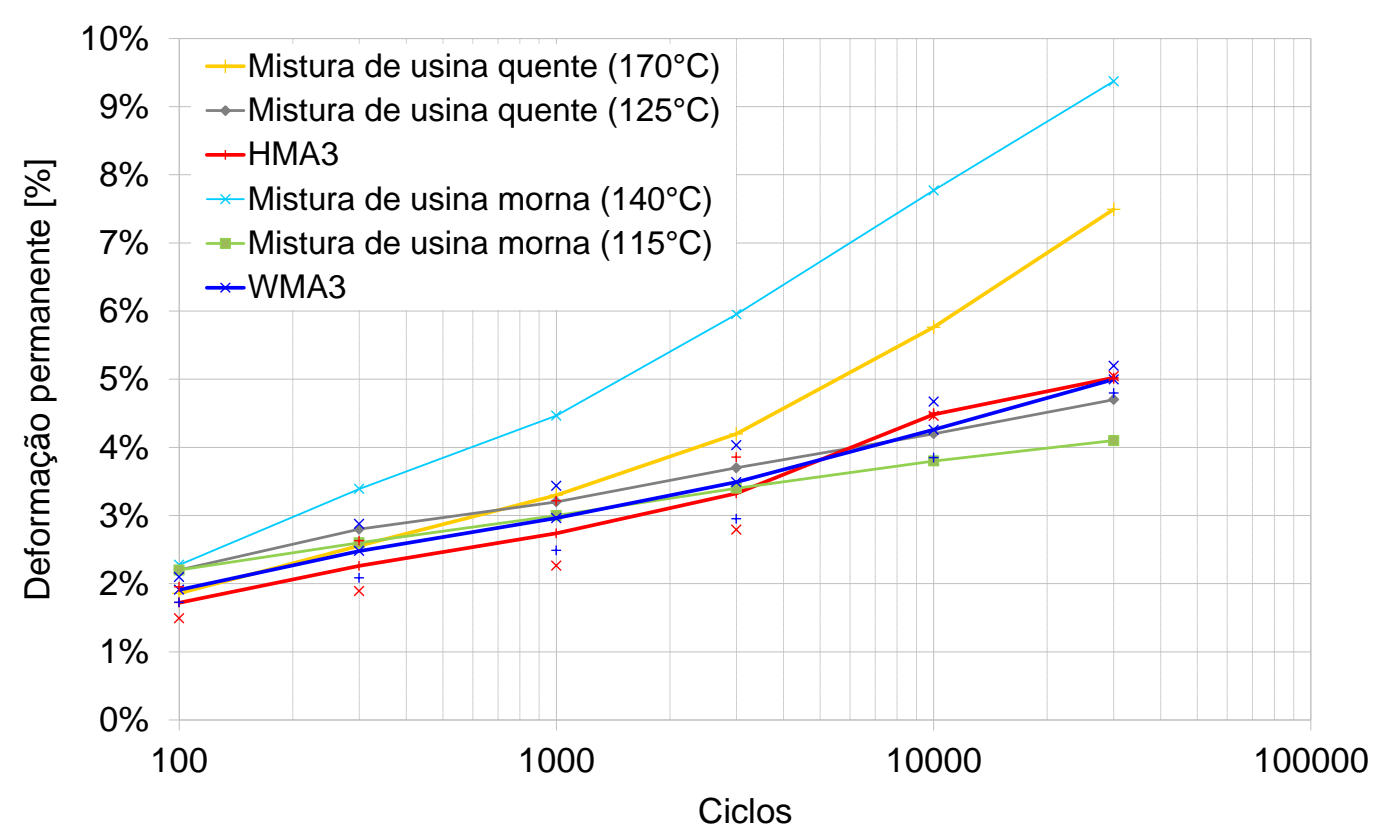

\begin{tabular}{cccccccc}
\hline $\begin{array}{c}\text { Tipo de } \\
\text { mistura asfáltica }\end{array}$ & $\begin{array}{c}\text { Temperatura de } \\
\text { compactação } \\
{\left[\begin{array}{c}\left.{ }^{\circ} \mathrm{C}\right]\end{array}\right.}\end{array}$ & 100 & 300 & 1000 & 3000 & 10000 & 30000 \\
\hline \multirow{2}{*}{ Mistura a quente de usina } & 170 & 1,9 & 2,6 & 3,3 & 4,2 & 5,8 & 7,5 \\
& 125 & 2,2 & 2,8 & 3,2 & 3,7 & 4,2 & 4,7 \\
\hline \multirow{2}{*}{ Mistura morna de usina } & 140 & 2,3 & 3,4 & 4,5 & 6,0 & 7,8 & 9,4 \\
\hline HMA3 & 115 & 2,2 & 2,6 & 3,0 & 3,4 & 3,8 & 4,1 \\
\hline WMA3 & 175 & 1,7 & 2,3 & 2,7 & 3,3 & 4,5 & 5,0 \\
\hline
\end{tabular}

Figura 104 - Deformação permanente em trilha de roda das misturas a quente e morna de usina, em comparação com as misturas de laboratório

Quando a compactação por rolagem das misturas de usina foi realizada em temperatura significativamente mais baixa, a densificação dos materiais foi mais efetiva (levando a menor VV) e o potencial à deformação permanente diminuiu.

A especificação europeia de BBTM 10B (EN 13108-2/06) fixa a deformação permanente máxima deste material em $15 \%$ após 3.000 ciclos no simulador de tráfego, enquanto no LTP/EPUSP tem-se recomendado que o afundamento em trilha de roda neste equipamento não ultrapasse $5 \%$ aos 30.000 ciclos. Considerando-se então tais limites, verifica-se que as misturas de usina os atenderiam na norma europeia (ainda que fosse uma aproximação com as misturas BBTM), mas não na recomendação brasileira, caso fossem compactadas em temperatura usual. Por outro lado, quando a densificação foi realizada em temperaturas mais baixas que aquelas recomendadas, as misturas de usina se tornaram mais resistentes à deformação permanente, atendendo o máximo recomendável no Brasil. 


\subsubsection{Dano por umidade induzida das misturas a quente e morna de usina}

$O$ ensaio de dano por umidade induzida foi realizado com as misturas a quente e morna de usina, segundo descrito no item 3.5.5. A Tabela 36 apresenta os resultados médios obtidos, bem como o número de CPs empregados (metade na situação de condicionamento à água e a outra metade como referência). Além disso, têm-se ainda os valores obtidos com as misturas de laboratório, para fins de comparação. Em seguida, são indicados os resultados de análise de variância dos parâmetros de RT e VV na Tabela 37.

Tabela 36 - Resultados do ensaio de dano por umidade induzida das misturas a quente e morna de

\begin{tabular}{|c|c|c|c|c|}
\hline & \multicolumn{4}{|c|}{ usina } \\
\hline & $\begin{array}{c}\text { Mistura a quente } \\
\text { de usina }\end{array}$ & $\begin{array}{c}\text { Mistura morna } \\
\text { de usina }\end{array}$ & НMA3 & WMA3 \\
\hline Quantidade de CPs & 8 & 6 & 8 & 6 \\
\hline RTnc ( $\pm \mathrm{DP})[\mathrm{MPa}]$ & $1,15( \pm 0,14)$ & $0,98( \pm 0,06)$ & $1,15( \pm 0,04)$ & $1,00( \pm 0,06)$ \\
\hline VVnc ( \pm DP $)[\%]$ & $7,2( \pm 0,1)$ & $7,8( \pm 0,1)$ & $7,6( \pm 0,1)$ & $7,7(0)$ \\
\hline $\mathrm{RTc}( \pm \mathrm{DP})[\mathrm{MPa}]$ & $0,81( \pm 0,08)$ & $0,74( \pm 0,05)$ & $1,01( \pm 0,04)$ & $0,82( \pm 0,05)$ \\
\hline VVc $( \pm \mathrm{DP})[\%]$ & $7,2( \pm 0,1)$ & $8,0(0)$ & $7,7( \pm 0,1)$ & $7,9(0)$ \\
\hline RRT & 0,71 & 0,76 & 0,88 & 0,82 \\
\hline
\end{tabular}

Tabela 37 - Análise de variância da resistência à tração e volume de vazios com misturas a quente e

\begin{tabular}{|c|c|c|c|c|c|c|c|c|c|}
\hline \multirow{2}{*}{$\begin{array}{l}\text { Tipo de } \\
\text { mistura } \\
\text { asfáltica }\end{array}$} & \multirow[b]{2}{*}{ Parâmetro } & \multicolumn{4}{|c|}{$\begin{array}{l}\text { Mistura morna } \\
\text { de usina }\end{array}$} & \multicolumn{4}{|c|}{ HMA3 } \\
\hline & & RTnc & VVnc & RTc & VVc & RTnc & VVnc & RTc & VVc \\
\hline \multirow{4}{*}{$\begin{array}{c}\text { Mistura a quente } \\
\text { de usina }\end{array}$} & RTnc & El & -- & -- & -- & $\mathrm{El}$ & -- & -- & -- \\
\hline & VVnc & -- & ED & -- & -- & -- & ED & -- & -- \\
\hline & RTc & -- & -- & $\mathrm{El}$ & -- & -- & -- & ED & -- \\
\hline & $\mathrm{VVc}$ & -- & -- & -- & ED & -- & -- & -- & ED \\
\hline \multirow{4}{*}{ WMA3 } & RTnc & ED & -- & -- & -- & & & & \\
\hline & VVnc & -- & El & -- & -- & & & & \\
\hline & RTc & -- & -- & ED & -- & & & & \\
\hline & VVc & -- & -- & -- & ED & & & & \\
\hline
\end{tabular}

Verifica-se que a perda de resistência no dano por umidade induzida das misturas a quente e morna de usina foi a mesma. Ademais, ao se considerar o valor mínimo de RRT apontado nas especificações DNIT ES031/06 e ES112/09 (mínimo de 0,7 ), observa-se também que os resultados obtidos com estas misturas atenderam tais normas.

Mais uma vez notou-se a eficiência do aditivo em manter a RRT, condição esta que se manteve após a usinagem, indicando que o produto não sofreu degradação. 


\subsubsection{Ensaios em pista}

\subsubsection{Macro e microtextura}

Logo após a execução do primeiro segmento de mistura a quente (agosto/2010), foram realizados levantamentos de macro e microtextura, respectivamente por testes de mancha de areia (ASTM E965-06) e de pêndulo britânico (ASTM E303-08), como ilustrado anteriormente na Figura 81. Estes testes faziam parte de uma outra pesquisa do LTP/EPUSP e, embora não tenham sido realizados no trecho de mistura morna, acredita-se que a textura superficial seja similar e, por consequência, os resultados também (para fins de ilustração, a Figura 105 mostra a aparência dos segmentos a quente e morno).
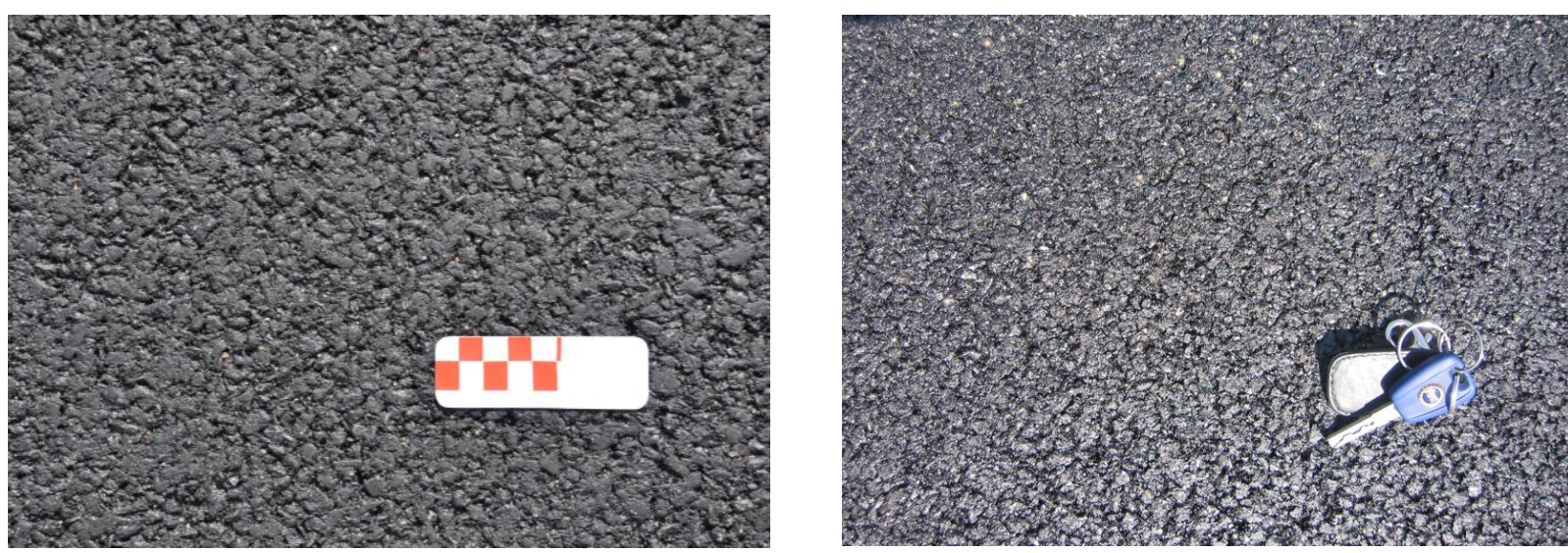

Foto: Assis Villela

Figura 105 - Aparência superficial dos revestimentos asfálticos dos trechos experimentais de mistura a quente e morna logo após a obra

Os levantamentos foram feitos a cada $20 \mathrm{~m}$, da estaca $80+640$ à $80+720$ nas trilhas interna e externa, com os ensaios de mancha de areia e com pêndulo britânico sendo sempre feitos próximos um ao outro. Os resultados são apresentados na Figura 106 e na Figura 107, respectivamente. 


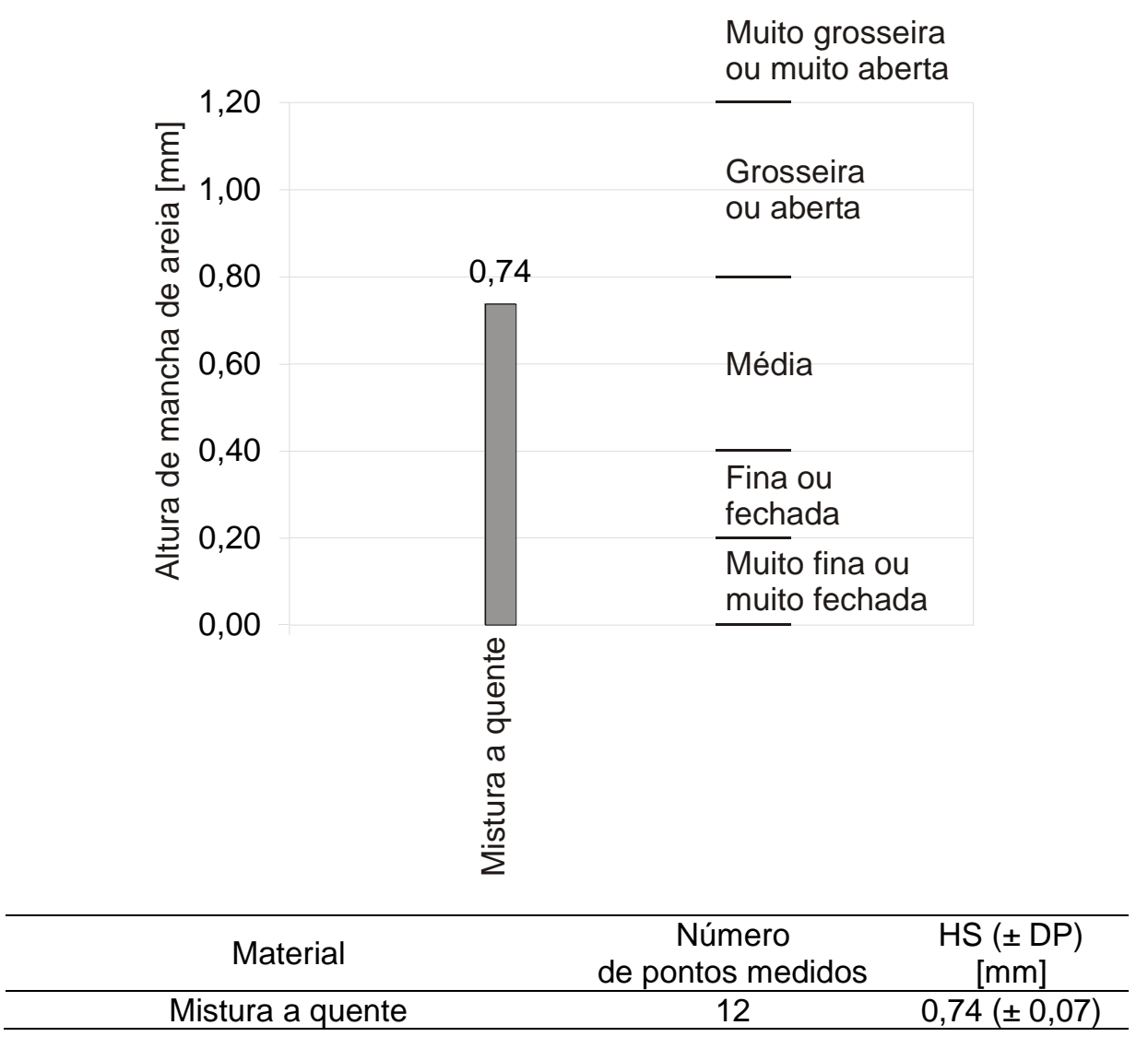

Figura 106 - Altura de mancha de areia no trecho experimental de mistura a quente

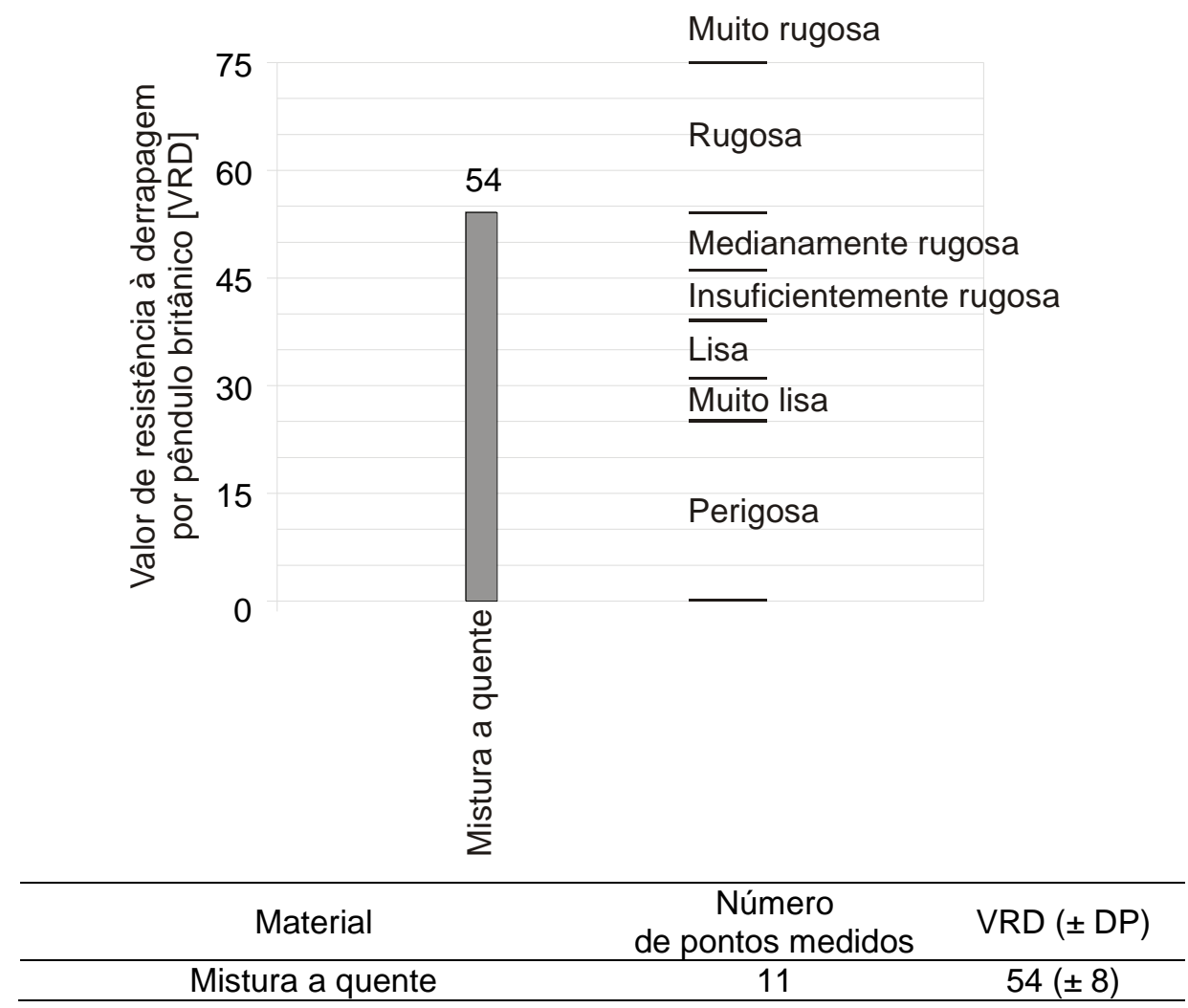

Figura 107 - Valor de resistência à derrapagem por pêndulo britânico no trecho experimental de mistura a quente 
Verifica-se que o revestimento de gap-graded com asfalto-borracha da Rodovia dos Bandeirantes foi classificado como tendo macrotextura média e microtextura medianamente rugosa (ainda que no limite com a classe rugosa).

Como se tem recomendado que a macrotextura de pavimentos asfálticos se situe entre $0,6 \mathrm{~mm}$ e 1,2 $\mathrm{mm}$ de altura média de mancha de areia, enquanto que o VRD mínimo recomendado é de 47 (BERNUCCl et al. 2008), a macro e a microtextura da camada de rolamento com a mistura a quente se enquadrou nestes limites, apresentando boas características relativas à aderência. 


\section{REDUÇÃO DA EMISSÃO DE POLUENTES E DO CONSUMO ENERGÉTICO}

\subsection{REDUÇÃO DA EMISSÃO DE POLUENTES: CONCENTRAÇÃO DE HIDROCARBONETOS POLICÍCLICOS AROMÁTICOS NA PRODUÇÃO E NA APLICAÇÃO DAS MISTURAS ASFÁLTICAS}

Esta pesquisa contemplou a comparação da concentração de hidrocarbonetos policíclicos aromáticos (HPAs) prioritários em particulados totais em suspensão (PTS), relativos a misturas asfálticas morna e a quente. As amostragens destes poluentes foram feitas em diferentes situações: (i) durante o processo de usinagem em laboratório; (ii) no momento do carregamento do caminhão em usina; e (iii) quando do lançamento do material em pista.

A análise é feita de modo simplificado, uma vez que há um número reduzido de amostras e não são considerados outros fatores que podem interferir nos resultados, como os HPAs provenientes da queima de combustível na operação dos equipamentos de campo, por exemplo.

Neste item, os níveis de HPAs em ambas as misturas (a quente e morna) em material particulado foram comparados, por se acreditar que a redução de temperatura das misturas mornas propiciasse a diminuição da formação de HPAs oriundos do material asfáltico. Para a captura destes componentes foi empregada uma bomba de vácuo convencional, com vazão de $34 \mathrm{~L} / \mathrm{min}$ (Figura 108), contendo filtro de fibra de quartzo ${ }^{15} \mathrm{com} 47 \mathrm{~mm}$ de diâmetro, acoplado a um holder (Figura 109).

\footnotetext{
${ }^{15}$ Como parte da preparação dos filtros de fibra de quartzo para a utilização, estes eram previamente aquecidos a $800^{\circ} \mathrm{C}$ por oito horas para a remoção de contaminantes orgânicos (como indicado em Vasconcellos et al., 2010).
} 


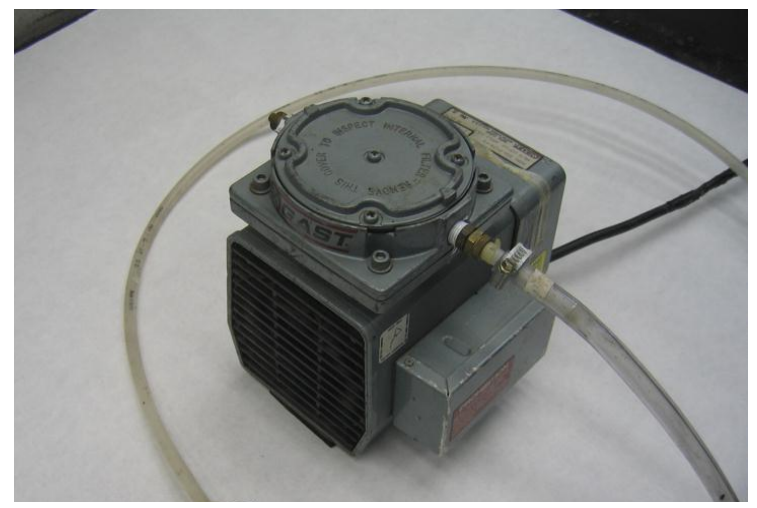

Figura 108 - Bomba de vácuo utilizada no estudo de emissões de material particulado
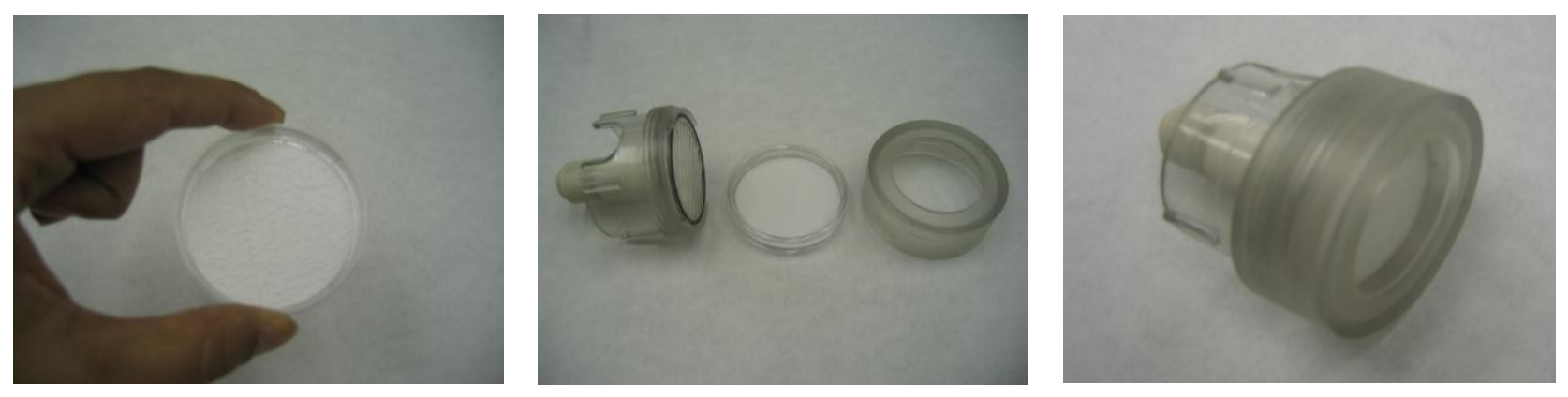

Figura 109 - Filtro de fibra de quartzo e holder empregados no estudo de emissões de material particulado

Após a amostragem, os materiais coletados foram submetidos à extração e à análise dos poluentes por cromatografia no Instituto de Química da USP (IQ/USP). Os HPAs prioritários avaliados foram: Acenafteno (Ace), Fluoreno (Flu), Fenantreno (Phe), Antraceno (Na), Fluoranteno (FI), Pireno (Py), Benzo[a]antraceno (B[a]An), Criseno (Chry), Benzo[b]fluoranteno (B[b]F), Benzo[k]fluoranteno (B[k]F), benzo[a]pireno (B[a]Py), benzo[e]pireno (B[e]Py), dibenzo[a,h]antraceno (DB[a,h]A), benzo[g,h,i]perileno (B[g,h,i]P) e indeno[1,2,3-cd]pireno (IPy).

Vale ressaltar que este capítulo apresenta os resultados obtidos no estudo preliminar, mas trata-se de uma pesquisa em andamento, em que ainda devem ser incluídas outras amostragens para uma análise mais aprofundada. Para os estudos laboratoriais que se encontram em prosseguimento, atualmente o LTP/EPUSP já dispõe de uma misturadora fechada, especialmente projetada para a amostragem de emissões durante a usinagem, onde tal equipamento possui uma saída lateral conectada à tubulação de exaustão para o encaixe do holder (Figura 110). Além disso, foram adquiridos tubos adsorventes para a amostragem simultânea dos compostos orgânicos voláteis (Figura 111), para melhor avaliação dos resultados. Por conseguinte, os dados relativos aos testes em andamento deverão ser publicados em breve. 

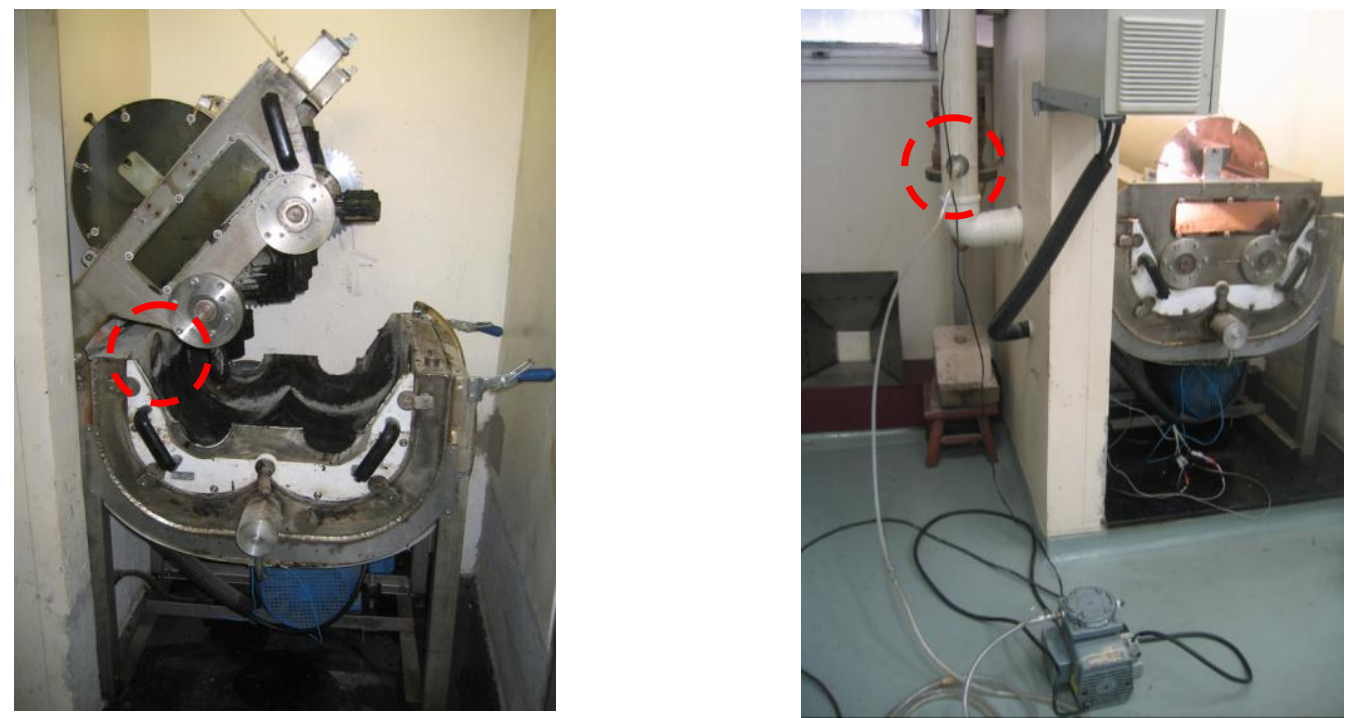

Figura 110 - Misturadora fechada e seu sistema de amostragem de emissões no LTP/EPUSP
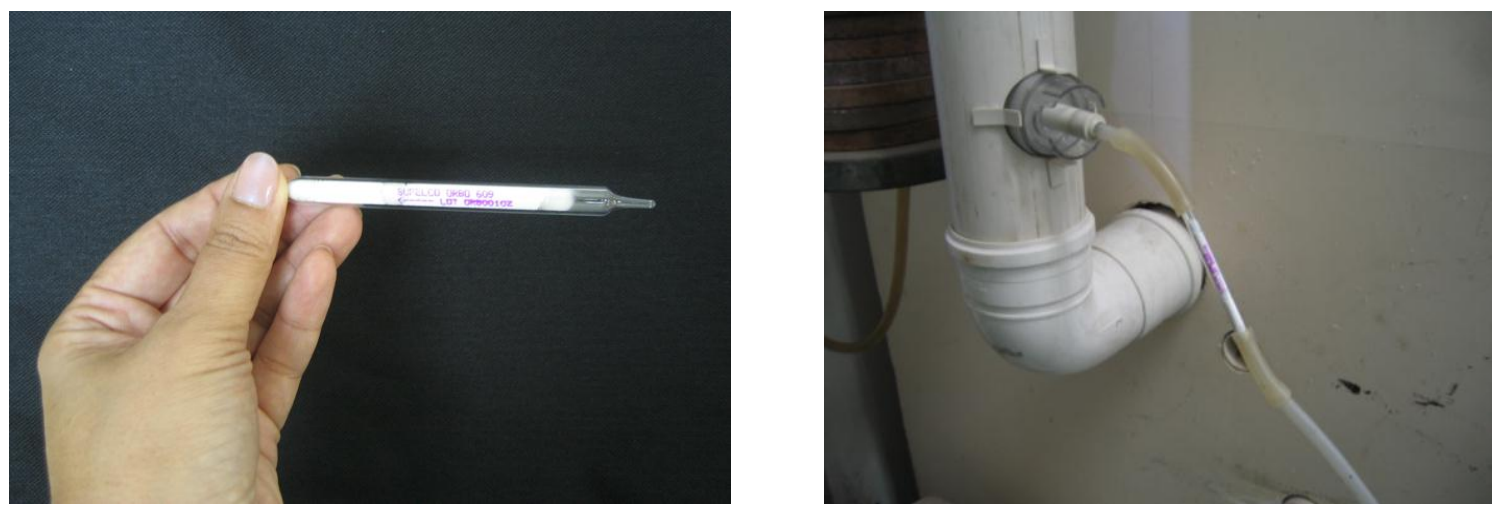

Figura 111 - Tubo adsorvente usado no estudo de emissões de compostos voláteis e sistema simultâneo de amostragem de emissões de voláteis e de material particulado durante usinagem em misturadora fechada do LTP/EPUSP

\subsubsection{Amostragem}

\subsubsection{Laboratório}

A amostragem em laboratório foi realizada no LTP/EPUSP, sendo feita durante o tempo usual de misturamento dos materiais neste laboratório, que é de cinco minutos, com a contagem de tempo sendo iniciada no momento de introdução dos agregados na misturadora. Basicamente, o processo consistia em inserir os agregados na misturadora, revolvê-los por $30 \mathrm{~s}$, incorporar o ligante e misturar todos os materiais ainda por mais $270 \mathrm{~s}$. O holder ficava posicionado $30 \mathrm{~cm}$ acima da 
misturadora (Figura 112) e a bomba de vácuo era mantida ligada durante tal período de cinco minutos.

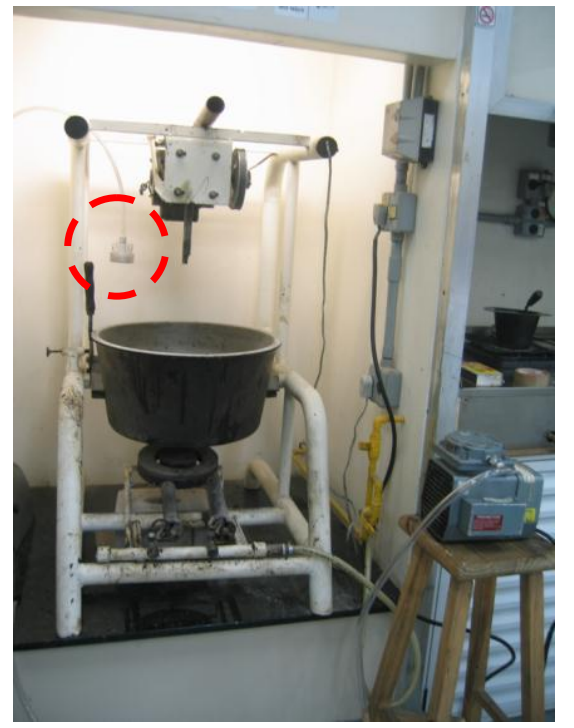

Figura 112 - Aparato para amostragem de emissões de material particulado na misturadora do LTP/EPUSP

\subsubsection{Usina}

A amostragem em usina foi realizada na Basalto 6/Estrutural, na cidade de Campinas (SP), por ocasião da execução do trecho experimental na Rodovia dos Bandeirantes. Para tanto, foram feitas coletas de material particulado logo abaixo do pugmill, com o holder conectado à bomba de vácuo sendo posicionado próximo à caçamba do caminhão recebedor de massa asfáltica (Figura 113). 

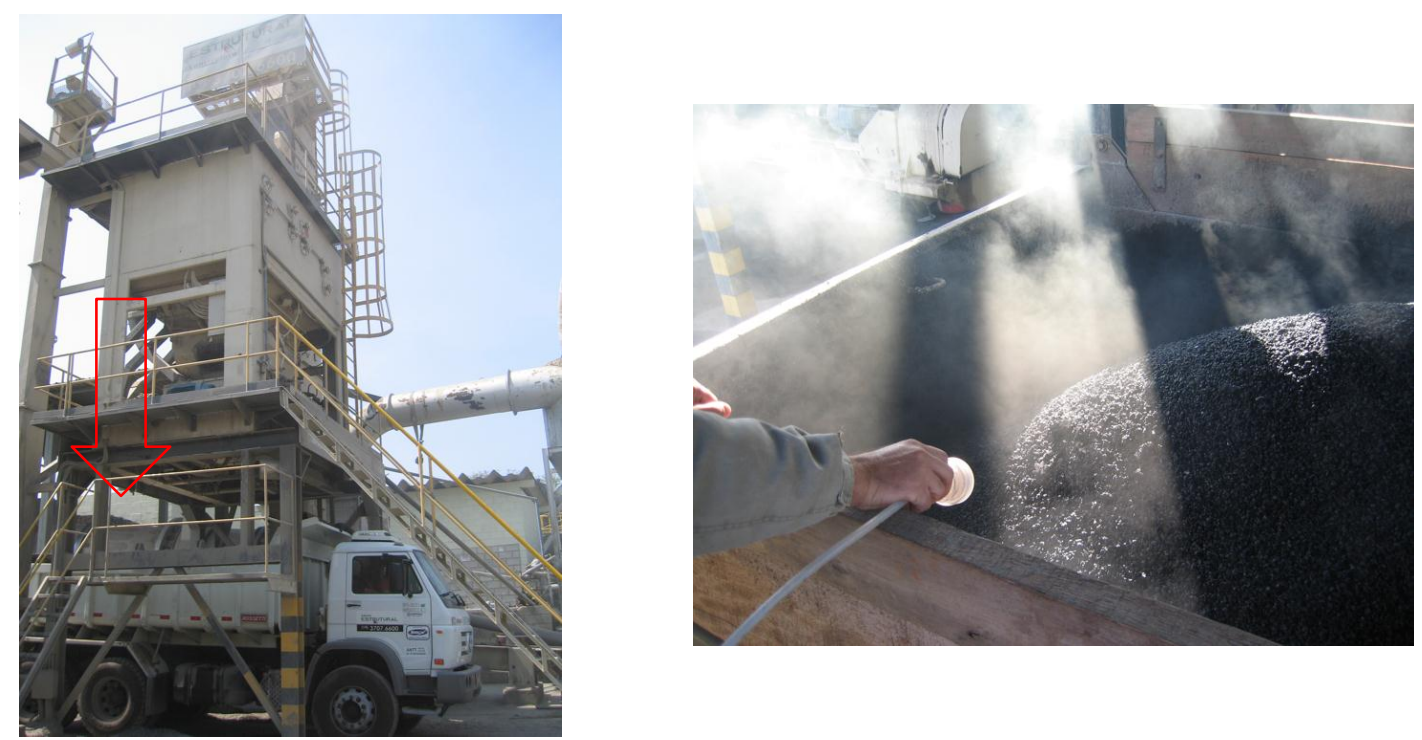

Figura 113 - Amostragem de emissões em usina de asfalto (a foto à esquerda indica o local de amostragem)

Nesta etapa estabeleceu-se um tempo de amostragem de cinco minutos, sendo sua contagem iniciada logo após a abertura do misturador para descarga de uma batelada. A propósito, um aspecto interessante observado diz respeito à visível diferença de fumos asfálticos liberados na abertura do misturador após a batelada entre as duas misturas, a usinada a quente e a morna (Figura 114).
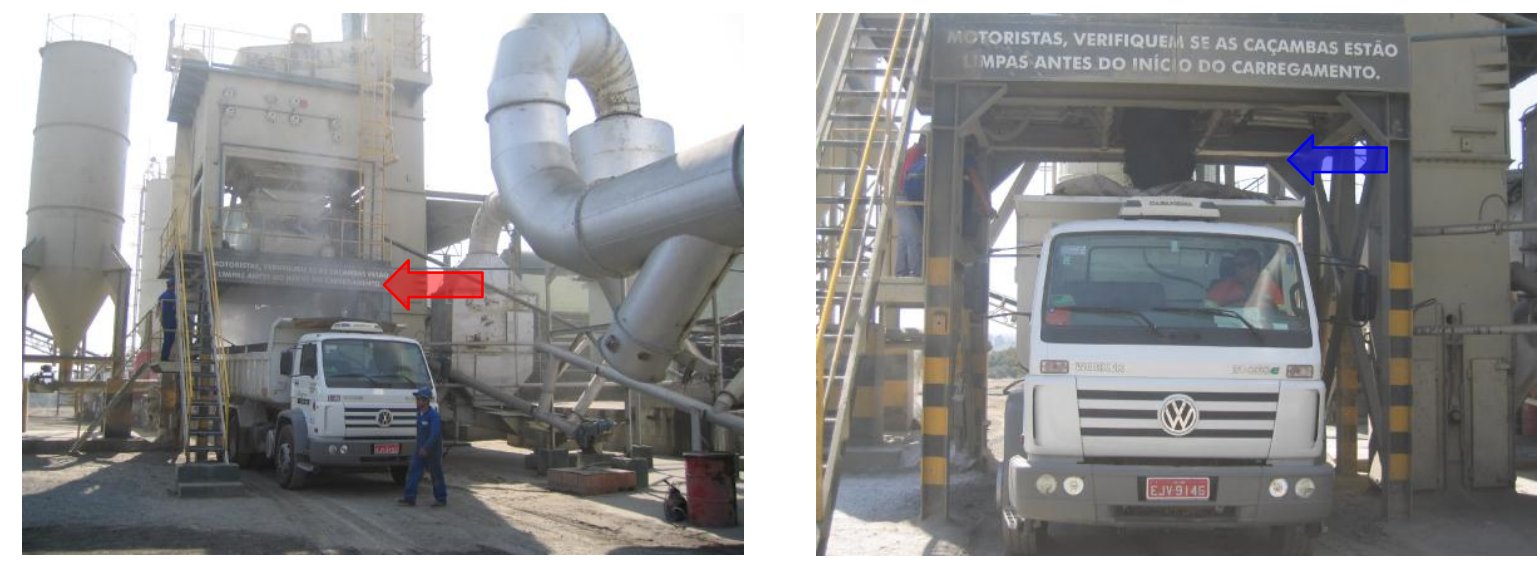

Figura 114 - Diferença de fumos asfálticos liberados pela mistura a quente e pela mistura morna quando da abertura do pugmill à esquerda e à direita, respectivamente

\subsubsection{Pista}

A amostragem em pista foi realizada na Rodovia dos Bandeirantes, durante a execução das obras que incluíam o segundo trecho experimental desta pesquisa. 
Nesta ocasião, foi feita a coleta de material particulado, com o holder conectado à bomba de vácuo sendo posicionado próximo à vibroacabadora (Figura 115).

As amostragens eram iniciadas no momento em que o caminhão descarregava a massa asfáltica na vibroacabadora e tinham duração de cinco minutos.

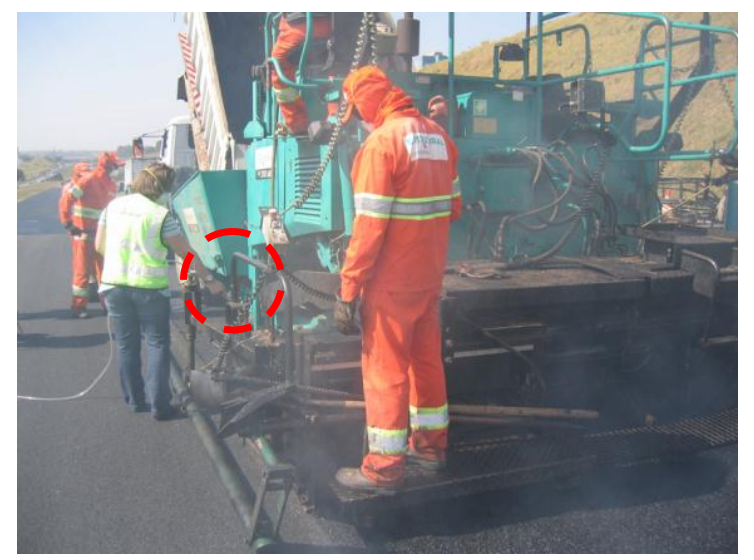

Figura 115 - Amostragem de emissões em pista, durante a execução do trecho experimental da Rodovia dos Bandeirantes

Em pista também foi possível observar o mesmo aspecto verificado em usina quanto à menor liberação de fumos de asfalto pela mistura morna em comparação com a mistura usinada a quente, como ilustrado na Figura 116.
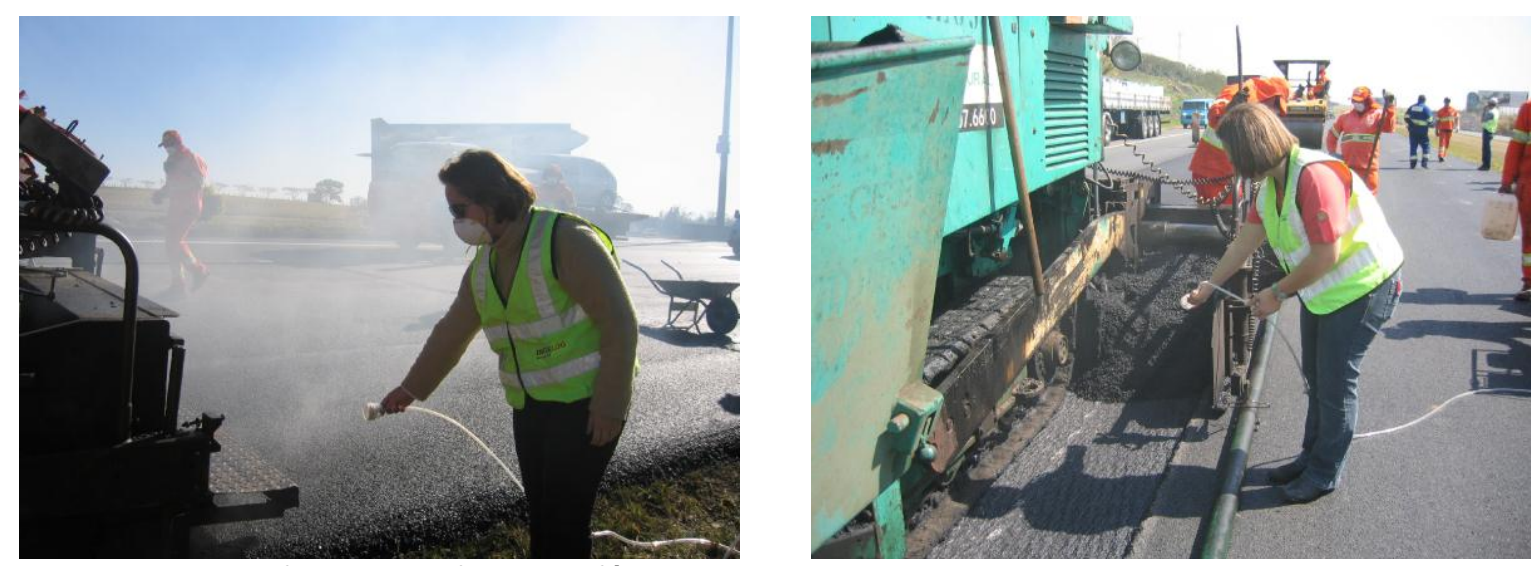

Figura 116 - Diferença de fumos asfálticos liberados pela mistura a quente e pela mistura morna quando da aplicação do material em pista à esquerda e à direita, respectivamente 


\subsubsection{Extração e análise por cromatografia}

No caso das amostras de material particulado, os compostos orgânicos foram extraídos dos filtros em equipamento Soxhlet por $24 \mathrm{~h}$ (60 ciclos), como indicado em Vasconcellos et al. (2010) e em Santos (2010), utilizando $200 \mathrm{~mL}$ de diclorometano como solvente para a extração líquida (Figura 117).

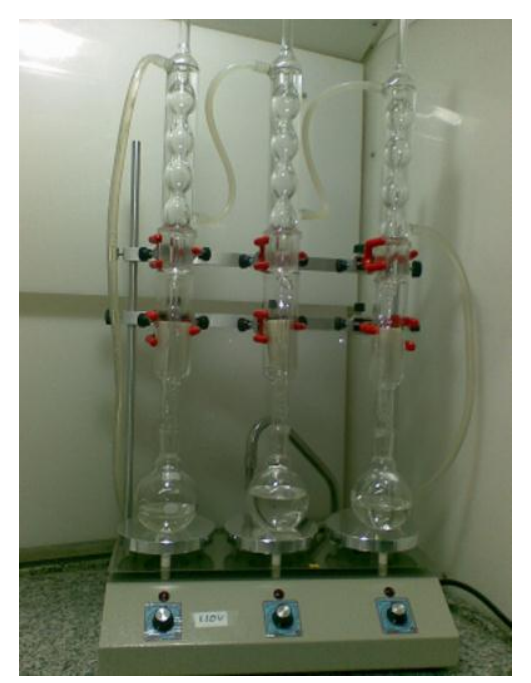

Figura 117 - Extração em equipamento Soxhlet no IQ/USP Foto: Santos (2010)

As amostras extraídas eram então concentradas a $500 \mu \mathrm{L}$ em um evaporador rotativo sob fluxo de $\mathrm{N}_{2}$. O extrato foi dissolvido em uma pequena quantidade de $\mathrm{n}$ hexano e transferido para o topo de uma coluna de vidro $(30 \times 0,7 \mathrm{~cm})$, contendo 2,5 $\mathrm{g}$ de sílica gel, a fim de fracionar as diversas classes de compostos presentes no extrato orgânico (Figura 118), como realizado por Santos (2010) e Vasconcellos et al. (2010). Os HPAs foram coletados por meio da passagem de $15 \mathrm{~mL}$ de tolueno e n-hexano (razão 5,6 / 9,4), sendo este material submetido em seguida à evaporação e secagem. 


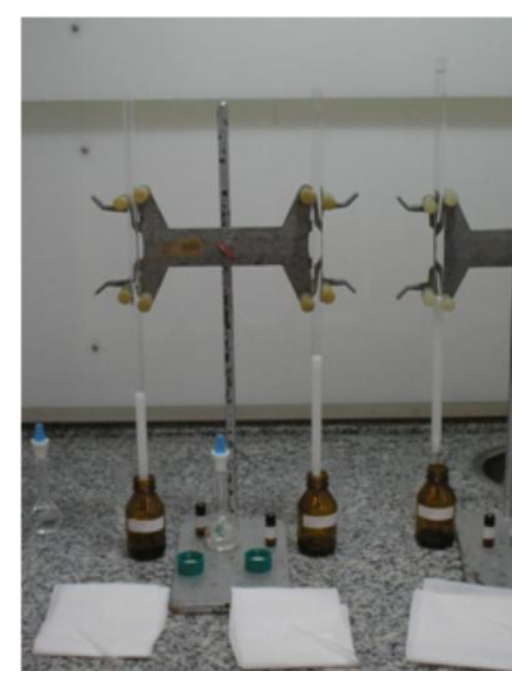

Figura 118 - Fracionamento do extrato orgânico no IQ/USP Foto: Santos (2010)

A análise quantitativa e qualitativa foi feita por meio de um cromatógrafo a gás com detector por ionização em chama (GC-FID, modelo Varian 3800). Para a separação dos compostos foi utilizada uma coluna capilar DB-5 com $30 \mathrm{~m}$ de comprimento, 0,25 mm de diâmetro interno e 0,25 $\mu \mathrm{m}$ de espessura de filme.

As temperaturas usadas no injetor e no detector do cromatógrafo foram $250 \mathrm{e}$ $290^{\circ} \mathrm{C}$, respectivamente. Já a sequência de temperaturas no forno foi: $40^{\circ} \mathrm{C}(1 \mathrm{~min})$; $40-150^{\circ} \mathrm{C}\left(10^{\circ} \mathrm{C} / \mathrm{min}\right) ; 150-290^{\circ} \mathrm{C}\left(5^{\circ} \mathrm{C} / \mathrm{min}\right) ; 290^{\circ} \mathrm{C}(30 \mathrm{~min})$. No mais, foi empregado nitrogênio como gás de arraste, as injeções foram feitas no modo splitless e $o$ volume injetado foi igual a $1 \mu \mathrm{L}$, do mesmo modo realizado por Santos (2010). Cabe mencionar que a análise no cromatógrafo contemplou os HPAs prioritários listados na Figura 18.

\subsubsection{Resumo esquemático das amostragens}

A Figura 119 apresenta um resumo esquemático dos materiais amostrados para a determinação dos HPAs provenientes das emissões asfálticas nesta pesquisa. As misturas WMA2 e HMA2 são concretos asfálticos usinados com CAP 30-45 e as misturas WMA3 e HMA3 são do tipo gap-graded com asfalto-borracha, conforme apresentado nos capítulos 3 e 4 anteriores. 


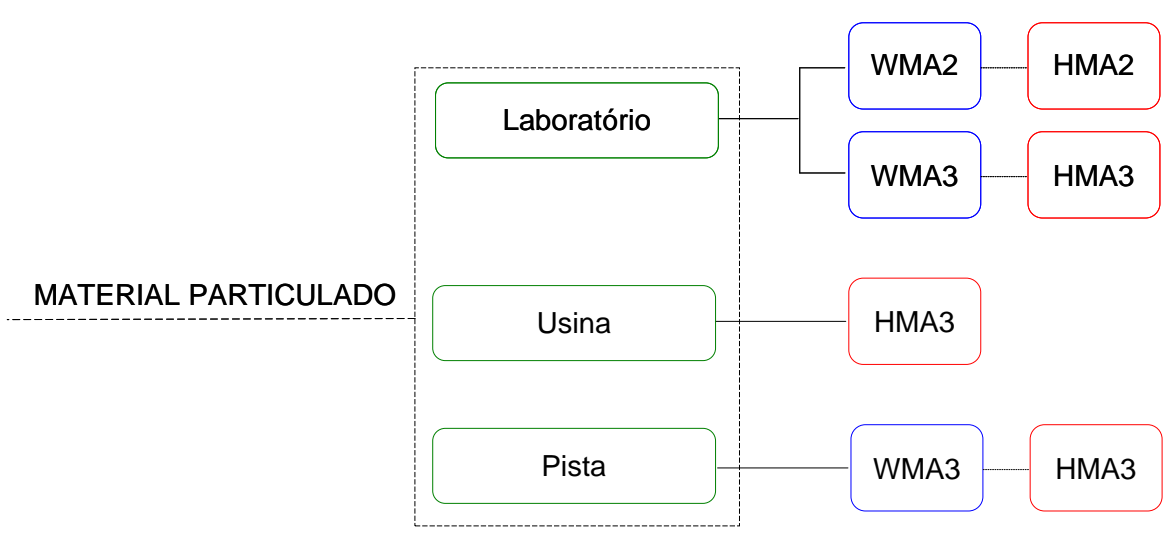

Figura 119 - Resumo esquemático das amostragens realizadas para a determinação dos HPAs em material particulado das emissões asfálticas

\subsubsection{Resultados}

A comparação dos resultados obtidos na presente pesquisa com limites recomendados de exposição ocupacional (como aqueles mencionados no item 2.3) deve ser feita de maneira criteriosa, atentando-se para as formas de amostragem e de análise, além dos tipos de poluentes a que tais limites se referem.

\subsubsection{Laboratório}

Para esta etapa foram usinadas em laboratório duas bateladas de cada tipo de mistura asfáltica a ser avaliada: HMA2 $\left(160^{\circ} \mathrm{C}\right)$, WMA2 $\left(135^{\circ} \mathrm{C}\right), \mathrm{HMA} 3\left(180^{\circ} \mathrm{C}\right)$ e WMA3 $\left(145^{\circ} \mathrm{C}\right)$. Em cada usinagem foram preparados $5 \mathrm{~kg}$ de massa asfáltica, sendo que no caso das misturas 2 foram empregados $250 \mathrm{~g}$ de CAP 30-45 (teor de $5,0 \%$ ) e para as misturas 3 foram utilizados $325 \mathrm{~g}$ de asfalto-borracha (teor de $6,5 \%$ ). Além disso, em cada usinagem foi feita uma amostragem de material particulado e, posteriormente, as duas amostras de cada mistura foram extraídas em conjunto, de forma a se obter maior massa para a análise dos HPAs provenientes das emissões asfálticas. Todo o processo foi realizado, segundo descrito nos itens 5.1.1 (amostragem) e 5.1.2 (extração e análise), e a Figura 120 apresenta os resultados. 


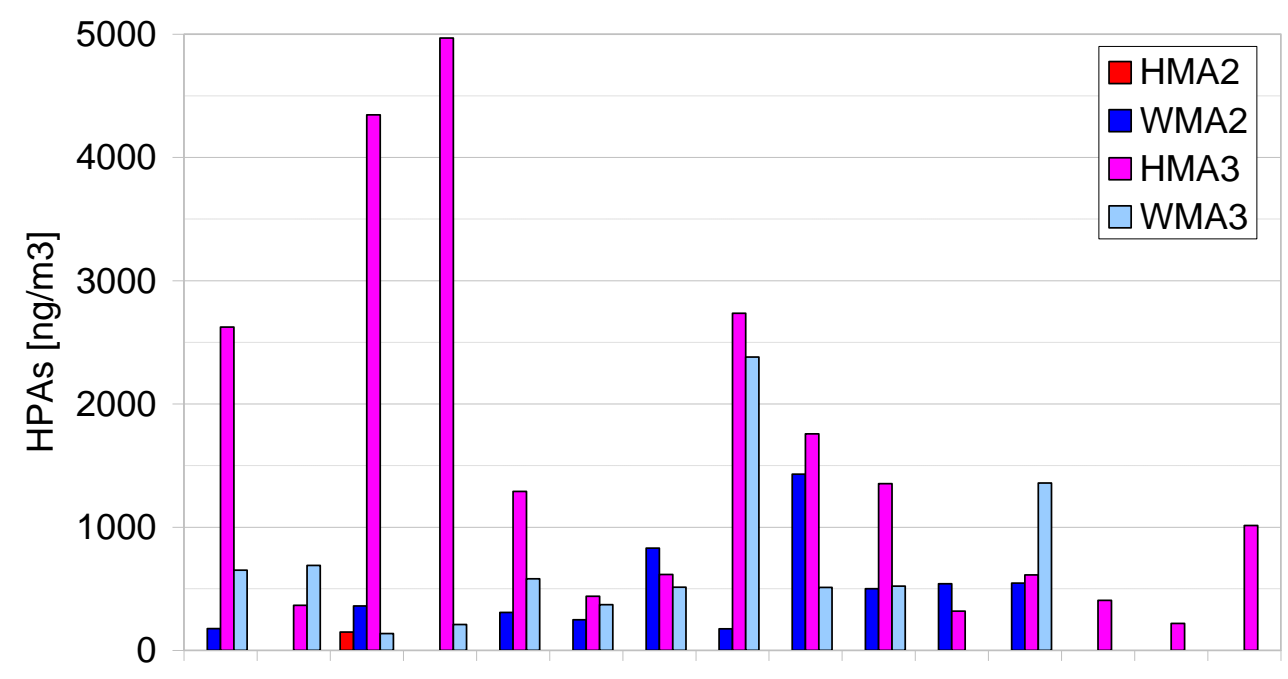

\begin{tabular}{|c|c|c|c|c|c|c|c|}
\hline HPA & $\begin{array}{l}\text { Número } \\
\text { de anéis }\end{array}$ & $\begin{array}{l}\mathrm{HMA2} \\
{\left[\mathrm{ng} / \mathrm{m}^{3}\right]}\end{array}$ & $\begin{array}{l}\text { WMA2 } \\
{\left[\mathrm{ng} / \mathrm{m}^{3}\right]}\end{array}$ & $\begin{array}{c}\text { WMA2 } \\
\text { em relação } \\
\text { a HMA2 } \\
{[\%]}\end{array}$ & $\begin{array}{l}\mathrm{HMA3} \\
{\left[\mathrm{ng} / \mathrm{m}^{3}\right]}\end{array}$ & $\begin{array}{l}\text { WMA3 } \\
{\left[\mathrm{ng} / \mathrm{m}^{3}\right]}\end{array}$ & $\begin{array}{c}\text { WMA3 } \\
\text { em relação } \\
\text { a HMA3 } \\
{[\%]}\end{array}$ \\
\hline Ace & 3 & $\mathrm{ND}$ & 177 & SR & 2624 & 651 & -303 \\
\hline Flu & 3 & ND & ND & ND & 366 & 690 & +89 \\
\hline Phe & 3 & 149 & 361 & +142 & 4345 & 137 & -3073 \\
\hline $\mathrm{Na}$ & 3 & ND & ND & ND & 4968 & 211 & -2256 \\
\hline $\mathrm{FI}$ & 4 & ND & 308 & SR & 1289 & 581 & -122 \\
\hline Py & 4 & ND & 248 & SR & 439 & 371 & -18 \\
\hline $\mathrm{B}[\mathrm{a}] \mathrm{An}$ & 4 & ND & 829 & SR & 616 & 513 & -20 \\
\hline Chry & 4 & ND & 176 & SR & 2735 & 2379 & -15 \\
\hline $\mathrm{B}[\mathrm{b}] \mathrm{F}$ & 5 & ND & 1430 & SR & 1757 & 512 & -243 \\
\hline $\mathrm{B}[\mathrm{k}] \mathrm{F}$ & 5 & ND & 501 & SR & 1352 & 521 & -160 \\
\hline $\mathrm{B}[\mathrm{a}] \mathrm{Py}$ & 5 & ND & 540 & SR & 318 & ND & SR \\
\hline $\mathrm{B}[\mathrm{e}] \mathrm{Py}$ & 5 & ND & 547 & SR & 612 & 1358 & +122 \\
\hline $\mathrm{DB}[\mathrm{a}, \mathrm{h}] \mathrm{A}$ & 5 & ND & ND & ND & 407 & ND & SR \\
\hline $\mathrm{B}[\mathrm{g}, \mathrm{h}, \mathrm{i}] \mathrm{P}$ & 6 & ND & ND & ND & 219 & ND & SR \\
\hline IPy & 6 & ND & ND & ND & 1014 & ND & SR \\
\hline \multicolumn{2}{|c|}{ Total } & 149 & 5117 & & 23061 & 7924 & \\
\hline
\end{tabular}

Onde:

ND = Não Detectável

$\mathrm{SR}=$ Sem Referência

Figura 120 - Concentração de HPAs durante a usinagem das misturas asfálticas no LTP/EPUSP

Nota-se que, no caso da HMA2, só foi possível detectar um tipo de HPA, o Phe (segundo Baird, 1999, o Phe é um HPA que pode se originar em materiais de origem petrolífera), mas o fato de não ter sido possível detectar outros HPAs no material particulado da HMA2 é um indicativo de que houve volatilização de tais compostos orgânicos. Segundo Keshava e Ong (1999), em temperaturas elevadas, como entre 150 e $180^{\circ} \mathrm{C}$, os HPAs volatilizam e tendem a criar um potencial para a exposição por inalação; conforme apresentado na Tabela 2, os HPAs possuem baixa pressão de vapor (entre $1,6 \times 10^{-2} \mathrm{MPa}$ a $25^{\circ} \mathrm{C}$ e $1,4 \times 10^{-8} \mathrm{MPa}$ a $20^{\circ} \mathrm{C}$ ), 
especialmente aqueles com maior número de anéis benzênicos, propiciando sua volatilização com o aumento de temperatura. Um exemplo desta situação foi relatado por Lecomte et al., (2007), que estudaram as emissões de uma mistura a quente, em comparação com uma mistura WAM-Foam ${ }^{\circledR}$ : notou-se que a fração volátil da mistura a quente foi superior a seis vezes àquela da mistura morna.

De qualquer modo, como nesta etapa da pesquisa houve somente a coleta de material particulado, não foi possível confirmar tal fato, o que fomentou a ideia de se utilizar o material adsorvente em testes futuros.

No caso da WMA2, identificou-se a presença de HPAs entre três e cinco anéis, em quantidades variáveis. À exceção do criseno, os maiores níveis encontrados foram verificados do $\mathrm{B}[\mathrm{a}] \mathrm{An}$ ao $\mathrm{B}[\mathrm{e}] \mathrm{Py}$ (de fato, conforme apresentado na Tabela 2, encontra-se HPAs quase que exclusivamente na fase particulada a partir do B[a]An). De acordo com Fernandes et al. (2009), a International Agency for Research on Cancer (IARC) considera os HPAs com 4 a 6 anéis aromáticos altamente mutagênicos e carcinogênicos, e os menores (2 e 3 anéis) muito tóxicos (ainda que menos mutagênicos).

Quando se faz a comparação entre HMA3 e WMA3 nota-se que a mistura a quente gerou todos os compostos prioritários avaliados e ainda indicou as maiores concentrações relativas a todos os HPAs, possivelmente devido à temperatura mais elevada da mistura a quente, com exceção do B[e]Py. De acordo com Osborne e Crosby (1987), o potencial carcinogênico do B[e]Py foi avaliado em uma série de estudos com ratos e alguns resultados foram positivos para a formação de tumores, o que não permite a conclusão de que este composto tenha tal efeito em humanos, mas deve-se tratá-lo como se fosse um carcinogênico. Por outro lado, o IARC não classifica o B[e]Py por carcinogenicidade em humanos (ASTDR, 2008).

Em relação às misturas 2 , as misturas 3 formaram concentrações mais elevadas de HPAs (totais), acreditando-se que tal diferença possa ser decorrente do tipo de ligante empregado em cada caso e da maior temperatura das misturas 3 . Os níveis de temperatura de usinagem dos materiais com CAP 30-45 e asfalto-borracha também são diferentes, e poderiam levar a uma maior emissão de HPAs por parte das misturas a quente. Mas tal argumento só se confirmaria com a análise também das frações voláteis, de forma a se ter uma avaliação mais detalhada.

No Brasil têm-se alguns estudos laboratoriais relativos às emissões de HPAs. $\mathrm{Na}$ Universidade Federal do Ceará, por exemplo, têm-se trabalhos já publicados por 
Fernandes et al. (2009) e Pinheiro et al. (2009). Os primeiros autores estudaram um CAP 50-70 procedente da refinaria Lubnor/Petrobras e observaram que os HPAs prioritários encontrados em maiores concentrações foram o $\mathrm{B}[\mathrm{b}] \mathrm{F}, \mathrm{B}[\mathrm{a}] \mathrm{Py}, \mathrm{IPy}$, $\mathrm{D}[\mathrm{a}, \mathrm{h}] \mathrm{A}$ e $\mathrm{B}[\mathrm{g}, \mathrm{h}, \mathrm{i}] \mathrm{P}$, cujas concentrações médias variaram entre 10,2 a 20,7 mg/kg de asfalto. Já Pinheiro et al. (2009) também estudaram o mesmo tipo de asfalto e encontraram as maiores concentrações de HPAs do B[b]F até o B[g,h,i]P, dentre os compostos prioritários, com concentrações variando entre 9,58 a 16,93 ng/g (as unidades indicadas pelos autores são diferentes, mas $1 \mathrm{mg} / \mathrm{kg}=1000 \mathrm{ng} / \mathrm{g}$ ).

Já em uma parceria entre o CENPES/Petrobras e a Universidade Federal de Santa Maria também foi desenvolvida uma pesquisa laboratorial sobre as emissões de HPAs de oito tipos de asfaltos brasileiros (todos com penetração 50-70, porém obtidos por diferentes métodos na refinaria, sendo três por resíduo asfáltico diluído com gasóleo leve ou pesado de vácuo, e os outros cinco provenientes de destilação direta). Neste estudo, realizado por Cravo et al. (2010), diversas amostras foram expostas ao calor em um equipamento fechado, desenvolvido para tal finalidade (Figura 121), variando-se o tempo de aquecimento (duas a oito horas) e a temperatura $\left(120\right.$ a $180^{\circ} \mathrm{C}$ ), sendo as emissões captadas em filtros (material particulado) e cartuchos (voláteis).
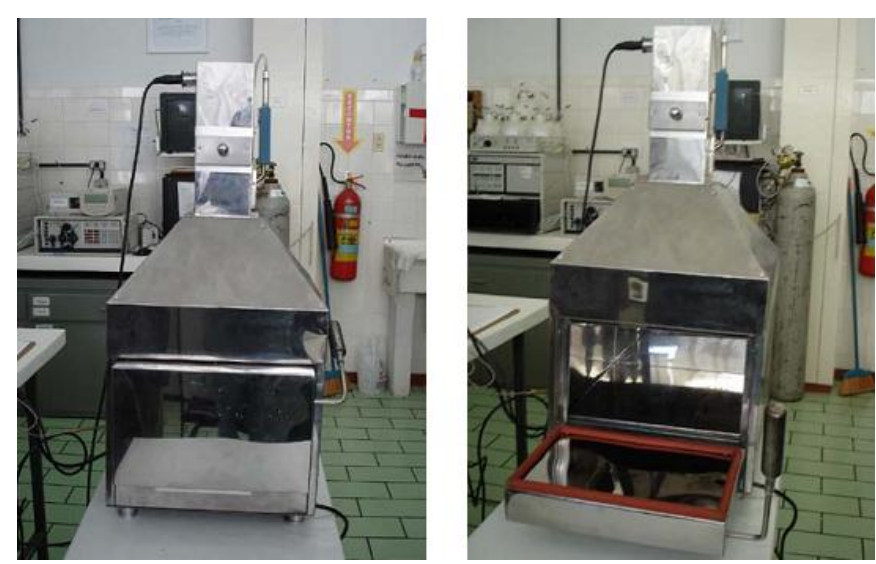

Figura 121 - Forno para geração e coleta de fumos de asfalto, utilizado por Cravo et al. (2010) retirado de Cravo et al. (2010)

Os resultados mostraram que, de fato, a situação de maior tempo e temperatura leva às maiores concentrações destes hidrocarbonetos. Ademais, notou-se ainda que os HPAs fluoreno e fenantreno (três anéis) apresentaram as maiores concentrações e, além disso, as amostras obtidas por destilação direta geraram menores níveis de emissões (possivelmente pela ausência de diluentes 
usualmente empregados para enquadrar o produto final na especificação vigente, segundo os autores), comprovando que a forma de produção do asfalto também tem influência nas emissões de HPAs.

\subsubsection{Usina}

Em usina foi realizada uma amostragem de material particulado por mistura asfáltica, tendo sido avaliadas a $\mathrm{HMA} 3\left(175^{\circ} \mathrm{C}\right)$ e a WMA3 $\left(145^{\circ} \mathrm{C}\right)$, utilizando-se a metodologia descrita no item 5.1.1.2, onde a extração e a análise de HPAs foram feitas como mencionado no item 5.1.2. Entretanto, os resultados relativos à WMA3 indicaram que ocorreu algum problema durante a amostragem e, deste modo, foram omitidos. A Figura 122 apresenta os valores encontrados com a HMA3. 


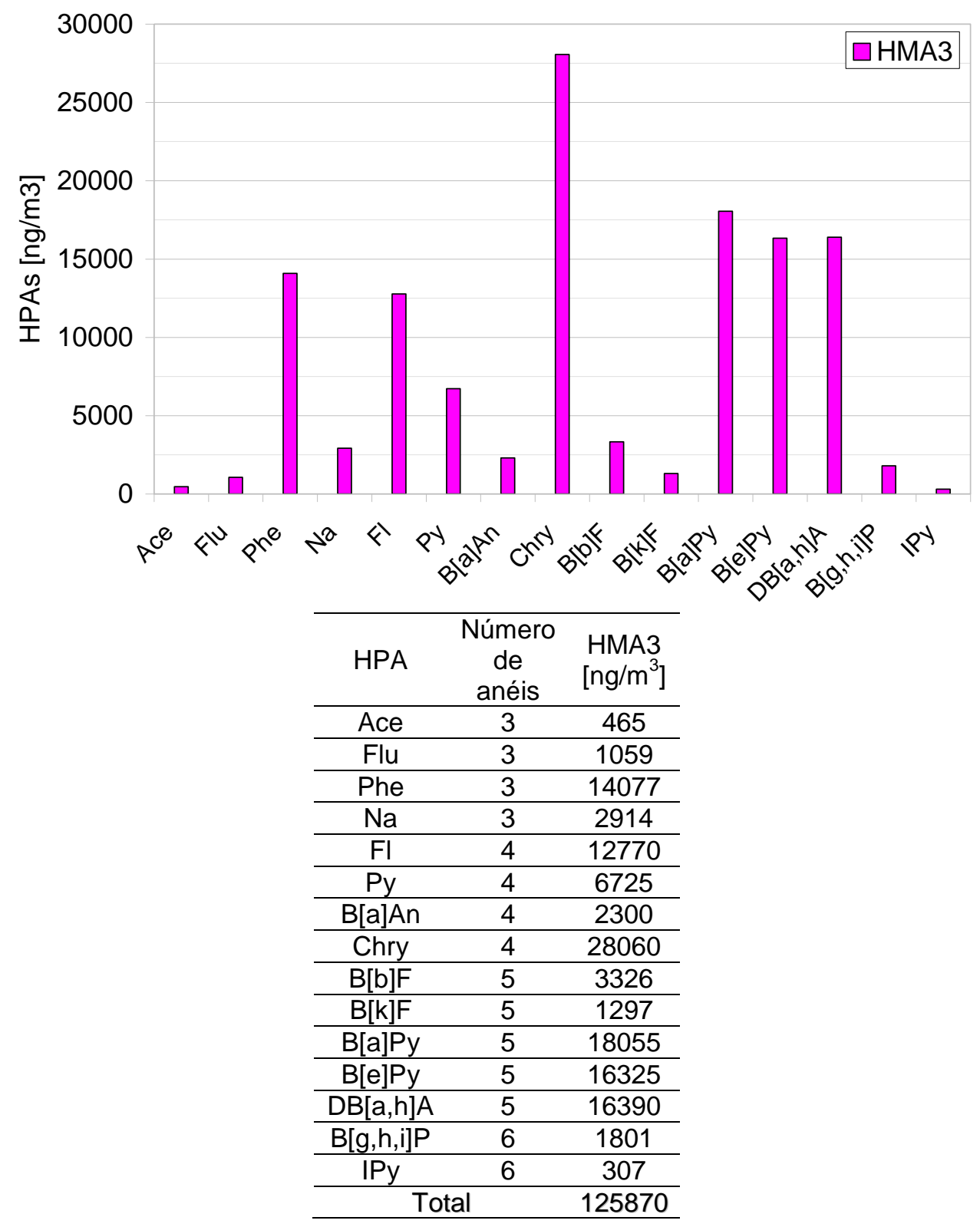

Figura 122 - Concentração de HPAs, logo abaixo do pugmill da usina de asfalto, durante o carregamento do caminhão com mistura a quente

Nota-se que o HPA encontrado de maneira mais abundante foi o Chry (mais de $28.000 \mathrm{ng} / \mathrm{m}^{3}$ ), seguido de $\mathrm{B}[\mathrm{a}] \mathrm{Py}, \mathrm{B}[\mathrm{e}] \mathrm{Py}, \mathrm{DB}[\mathrm{a}, \mathrm{h}] \mathrm{A}$ já em níveis mais baixos (aproximadamente entre 16.000 e $18.000 \mathrm{ng} / \mathrm{m}^{3}$ ). Particularmente, o B[a]Py é muitas vezes tido como a referência em estudos relativos à exposição ocupacional (BAIRD, 1999; RAVINDRA et al., 2008), já que o US Department of Health and Human Services (HHS) o classifica como um reconhecido carcinogênico em animais, e a IARC e a USEPA o declaram como provável carcinogênico em humanos (ATSDR, 2008). 
No geral, verifica-se que as maiores emissões de HPAs se concentraram em compostos com 4 e 5 anéis. Dentro deste contexto, vale o comentário feito no item anterior (5.1.4.1), de que HPAs com 4 a 6 anéis aromáticos são considerados altamente mutagênicos e carcinogênicos pela IARC, segundo Fernandes et al. (2009).

Por outro lado, a amostragem durante a preparação da HMA3 mostrou que as concentrações de HPAs em usina eram mais elevadas que aquelas verificadas em laboratório. Entretanto, deve-se atentar para o fato de que o volume de material fabricado durante a amostragem laboratorial era muito menor do que aquela produzida em usina: enquanto em laboratório trabalhou-se com alguns quilos de mistura asfáltica, em usina a produção é da ordem de toneladas.

\subsubsection{Pista}

Em pista foram realizadas duas amostragens de material particulado por mistura asfáltica, tendo sido avaliadas a HMA3 $\left(175^{\circ} \mathrm{C}\right)$ e a WMA3 $\left(145^{\circ} \mathrm{C}\right)$, utilizando-se a metodologia descrita no item 5.1.1.3. A extração e análise de HPAs foram feitas como mencionado no item 5.1.2, cujos resultados são apresentados na Figura 123. 


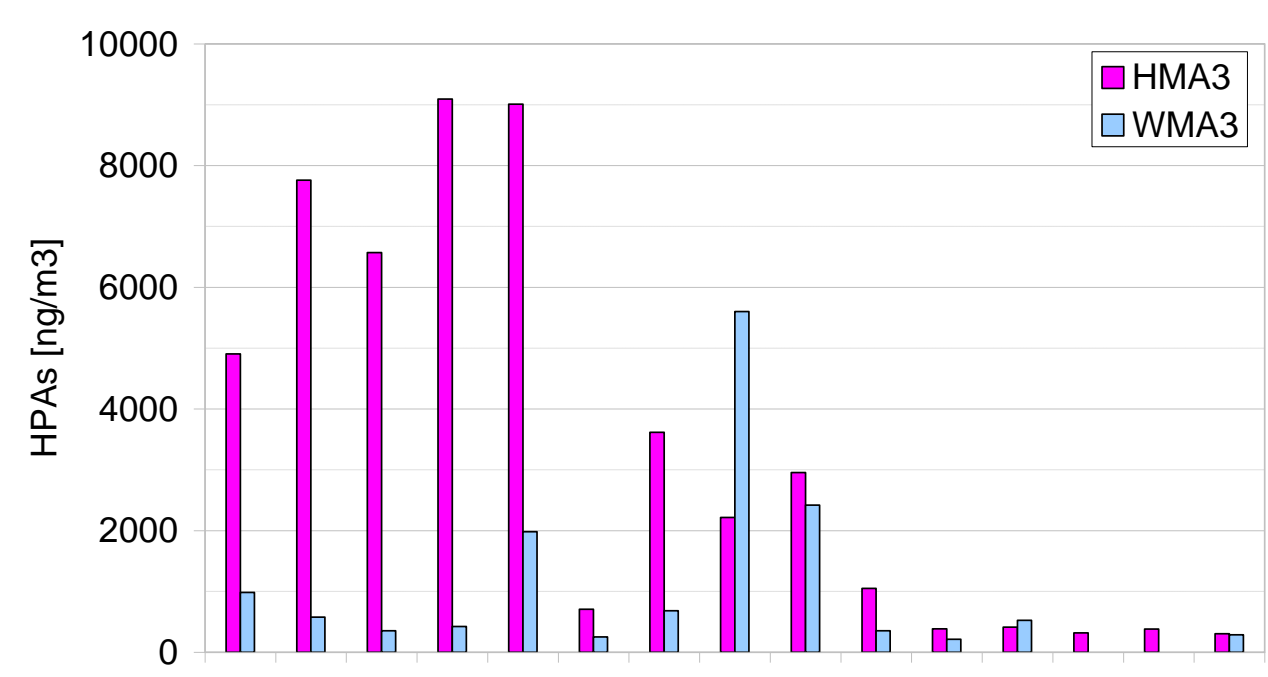

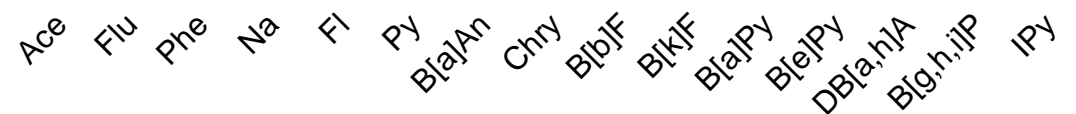

\begin{tabular}{ccccc}
\hline HPA & $\begin{array}{c}\text { Número } \\
\text { de } \\
\text { anéis }\end{array}$ & $\begin{array}{c}\text { HMA3 } \\
{\left[\mathrm{ng} / \mathrm{m}^{3}\right]}\end{array}$ & $\begin{array}{c}\text { WMA3 } \\
{\left[\mathrm{ng} / \mathrm{m}^{3}\right]}\end{array}$ & $\begin{array}{c}\text { WMA3 } \\
\text { em relação } \\
\text { a HMA3 } \\
{[\%]}\end{array}$ \\
\hline Ace & 3 & 4903 & 982 & -399 \\
\hline Flu & 3 & 7759 & 576 & -1246 \\
\hline Phe & 3 & 6571 & 353 & -1762 \\
\hline Na & 3 & 9094 & 424 & -2047 \\
\hline Fl & 4 & 9009 & 1982 & -354 \\
\hline Py & 4 & 706 & 253 & -179 \\
\hline B[a]An & 4 & 3615 & 682 & -430 \\
\hline Chry & 4 & 2215 & 5600 & +60 \\
\hline B[b]F & 5 & 2956 & 2418 & -22 \\
\hline B[k]F & 5 & 1050 & 353 & -198 \\
\hline B[a]Py & 5 & 385 & 212 & -82 \\
\hline B[e]Py & 5 & 412 & 524 & +27 \\
\hline DB[a,h]A & 5 & 318 & ND & SR \\
\hline B[g,h,i]P & 6 & 382 & ND & SR \\
\hline IPy & 6 & 306 & 288 & -6 \\
\hline Total & & 49681 & 14647 & \\
\hline
\end{tabular}

Onde:

ND = Não Detectável

$\mathrm{SR}=$ Sem Referência

Figura 123 - Concentração de HPAs no espalhamento da mistura asfáltica em pista

À exceção do Chry e do B[e]Py, a WMA3 apresentou menor concentração de HPAs que a HMA3, provavelmente em decorrência da diferença de temperatura. Além disso, verifica-se maior abundância de HPAs de três e quatro anéis na HMA3, o que deve ser encarado como ponto positivo, pois o potencial carcinogênico e mutagênico, embora existente, é menor do que seria em uma situação com HPAs maiores. 
Watts et al. (1998) monitoraram operários de pavimentação em obras com misturas asfálticas convencionais, bem como modificadas com borracha de pneu moído (com teores de 12, 15 e 20\%), em três Estados norte-americanos, com o objetivo de caracterizar e comparar a exposição ocupacional a HPAs e a materiais particulados com diâmetro inferior a 2,5 $\mu \mathrm{m}$. No mais, trabalhadores não expostos também foram incluídos para comparação. Uma análise estatística dos resultados mostrou que, no geral, não havia diferenças significativas, com exceção de dois locais com mistura com asfalto-borracha em que os níveis de HPAs carcinogênicos estavam significativamente elevados. Mas ainda que este estudo também tenha mostrado que em todos os locais a exposição ao B[a]Py tenha indicado concentrações extremamente baixas em comparação com o ar de muitas cidades, os autores frisam que os trabalhadores de pavimentação ficam amplamente expostos a outros HPAs suspeitos de carcinogenicidade.

\subsection{REDUÇÃO DO CONSUMO ENERGÉTICO: ESTIMATIVA DA ECONOMIA DE COMBUSTÍVEL}

Os processos de usinagem e compactação em campo das misturas mornas deste estudo foram executados do mesmo modo que seriam com uma mistura convencional, exceto no que se refere à redução da temperatura de usinagem e à inclusão do aditivo surfactante.

Deste modo, neste capítulo apresenta-se uma estimativa simples da economia de energia com a diminuição da secagem/vaporização d'água/aquecimento dos agregados para a produção das misturas mornas em usina, em comparação com misturas a quente, calculando-se ainda a economia de gastos com combustíveis. Neste trabalho, dá-se enfoque à secagem e ao aquecimento dos agregados em usina, pois esta é uma etapa que demanda grande consumo energético na produção de misturas asfálticas aquecidas, conforme relatado no item 2.4 .

O cálculo da demanda de energia foi realizado tal como indicado em Romier et al. (2006) e Olard (2008), a partir do estabelecimento de alguns parâmetros (Tabela 38), e com o uso das expressões (3) a (6) apontadas a seguir (onde $\mathrm{m}_{\mathrm{agr}}=$ 
massa dos agregados; $t_{a g r}=$ temperatura de aquecimento dos agregados $\mathrm{e}$ $t_{a m b}=$ temperatura ambiente).

Tabela 38 - Parâmetros adotados para o cálculo da economia de energia

\begin{tabular}{cc}
\hline Parâmetro & Valor \\
\hline calor específico dos agregados $\left(\mathrm{C}_{\text {agr }}\right)$ & $0,85 \mathrm{~kJ} / \mathrm{kg} /{ }^{\circ} \mathrm{C}$ \\
\hline calor específico da água $\left(\mathrm{C}_{\mathrm{a}}\right)$ & $4,2 \mathrm{~J} / \mathrm{kg} /{ }^{\circ} \mathrm{C}$ \\
\hline calor específico de vapor $\left(\mathrm{C}_{\mathrm{v}}\right)$ & $1,85 \mathrm{~J} / \mathrm{kg} /{ }^{\circ} \mathrm{C}$ \\
\hline calor latente de vaporização da água (clv) & $2250 \mathrm{~kJ} / \mathrm{kg} /{ }^{\circ} \mathrm{C}$ \\
\hline teor de umidade dos agregados $\left(\mathrm{U}_{\mathrm{agr}}\right)$ & $3 \%$ \\
\hline
\end{tabular}

- Energia para aquecimento dos agregados (em kJ)

$\mathrm{C}_{\text {agr }} \times \mathrm{m}_{\mathrm{agr}} \times\left(\mathrm{t}_{\mathrm{agr}}-\mathrm{t}_{\mathrm{amb}}\right)$

- Energia para aquecimento da água (em kJ)

$$
\mathrm{C}_{\mathrm{a}} \times\left(\frac{\mathrm{m}_{\mathrm{agr}}}{\mathrm{m}_{\mathrm{agr}}-\frac{\mathrm{u}}{100}{ }^{*} \mathrm{~m}_{\mathrm{agr}}}-1\right) \times \mathrm{m}_{\mathrm{agr}} \times\left(100-\mathrm{t}_{\mathrm{amb}}\right)
$$

- Energia para vaporização d'água (em kJ)

$$
\operatorname{clv} x\left(\frac{m_{a g r}}{m_{a g r}-\frac{u}{100} * m_{a g r}}-1\right) \times m_{a g r}
$$

- Energia para aquecimento do vapor d'água (em kJ)

$$
\mathrm{C}_{\mathrm{v}} \times\left(\frac{\mathrm{m}_{\mathrm{agr}}}{\mathrm{m}_{\mathrm{agr}}-\frac{\mathrm{u}}{100} * \mathrm{~m}_{\mathrm{agr}}}-1\right) \times \mathrm{m}_{\mathrm{agr}} \times\left(\mathrm{t}_{\mathrm{agr}}-100\right)
$$

\subsubsection{Mistura morna do trecho experimental da Rodovia Presidente Dutra}

Neste cálculo levou-se em conta que a temperatura ambiente na noite em que foi feita a obra da Rodovia Presidente Dutra era de aproximadamente $15^{\circ} \mathrm{C}$ e que foi 
empregada uma temperatura de secagem/vaporização d'água/aquecimento dos agregados de $135^{\circ} \mathrm{C}$ na preparação da mistura morna na usina de asfalto da Serveng Barueri. Por outro lado, como não houve a execução de um segmento de mistura a quente para comparação, a estimativa da redução do consumo energético nesta fase da usinagem supôs que, em contrapartida, seria necessária uma temperatura de $170^{\circ} \mathrm{C}$ para os agregados em uma mistura convencional.

Sabendo-se que foram usinadas cerca de $160 \mathrm{t}$ de mistura morna nesta ocasião, e que a quantidade de agregados secos correspondia então a 94,8\% deste material (para o teor de ligante de 5,2\%), a energia estimada gasta para secar/vaporizar a água/aquecer os agregados na mistura morna do trecho experimental e em uma mistura a quente com materiais similares é apresentada na Tabela 39.

Tabela 39 - Estimativa de energia necessária para secar/vaporizar a água/aquecer os agregados na usinagem de 160 t mistura morna do trecho experimental da Rodovia Presidente Dutra e de uma mistura a quente

\begin{tabular}{ccc}
\hline \multirow{2}{*}{ Parâmetro } & $\begin{array}{c}\text { Mistura morna } \\
\text { do trecho experimental }\end{array}$ & Mistura a quente \\
\cline { 2 - 3 } & Energia estimada [MJ] \\
\hline Aquecimento dos agregados & 15.471 & 19.984 \\
\hline Aquecimento da água & 1.675 & 1.675 \\
\hline Vaporização d'água & 10.555 & 10.555 \\
\hline Aquecimento do vapor & 304 & 608 \\
\hline Total & 28.005 & 32.821 \\
\hline $\begin{array}{c}\text { Redução de energia com os agregados } \\
\text { na mistura morna [\%] }\end{array}$ & & \multirow{2}{*}{15} \\
\hline
\end{tabular}

A usina da Serveng Barueri costuma utilizar gás GLP na produção de misturas asfálticas convencionais, consumindo cerca de $5,8 \mathrm{~kg}$ de combustível por tonelada de mistura. Ao se considerar uma redução de $15 \%$ de energia para produzir a mistura morna, tal consumo cairia para $4,9 \mathrm{~kg} / \mathrm{t}$. Como o preço médio do GLP no Brasil é de cerca de $\mathrm{R} \$ 26,16 / 13 \mathrm{~kg}^{16}$, a estimativa de gasto de combustível para produzir $160 \mathrm{t}$ de mistura convencional seria de $\mathrm{R} \$ 1.865,28$, enquanto que na mistura morna este valor cairia para $R \$ 1.575,84$, gerando uma economia de aproximadamente $\mathrm{R} \$ 290,00$.

Estendendo-se os cálculos para uma situação em que seria necessário pavimentar uma faixa de $1 \mathrm{~km}$ de comprimento, com 3,6 m de largura e $6 \mathrm{~cm}$ de

${ }^{16}$ Preço médio (distribuidora) no município de São Paulo, na semana entre 24/04/11 a 30/04/11, segundo levantamento da Agência Nacional do Petróleo, Gás Natural e Biocombustíveis. Disponível em: <http://www.anp.gov.br>. Acesso em: 30 abr. 2011. 
espessura (a mesma do trecho experimental), com uma mistura de massa específica aparente média de $2,379 \mathrm{~g} / \mathrm{cm}^{3}$ (verificada em pista), estima-se que a quantidade necessária de material seria de cerca de 514 toneladas. Dentro deste contexto, verifica-se que o uso desta mistura morna levaria à uma economia de aproximadamente $\mathrm{R} \$ 930,00$ por quilômetro executado.

Mas vale ressaltar que tais valores são produto das mesmas hipóteses adotadas anteriormente e são variáveis em função de fatores como, por exemplo, temperatura ambiente, temperatura dos agregados e teor de umidade dos materiais pétreos.

\subsubsection{Mistura morna do trecho experimental da Rodovia dos Bandeirantes}

Inicialmente, para o cálculo da redução de energia consumida com secagem/vaporização d'água/aquecimento dos agregados devido à utilização da mistura morna nos segmentos da Rodovia dos Bandeirantes, considerou-se que a temperatura ambiente nos dias de obra era de cerca de $25^{\circ} \mathrm{C}$. Além disso, levou-se em conta que a temperatura empregada com os agregados na usina da Basalto/Estrutural era de $145^{\circ} \mathrm{C}$ para a mistura morna e de $180^{\circ} \mathrm{C}$ para a mistura a quente.

Sabendo-se que foram usinadas cerca de $450 \mathrm{t}$ de mistura morna e que a quantidade de agregados secos correspondia então a 93,5\% deste material (para o teor de ligante de 6,5\%), calculou-se a energia demandada para produzir a mesma quantidade de mistura a quente, no que se refere aos agregados, cujos resultados são apresentados na Tabela 40.

Tabela 40 - Estimativa de energia necessária para secar/vaporizar a água/aquecer os agregados na usinagem de 450 t de misturas morna e quente do trecho experimental da Rodovia dos Bandeirantes

\begin{tabular}{ccc}
\hline \multirow{2}{*}{ Parâmetro } & Mistura morna & $\begin{array}{c}\text { Mistura a } \\
\text { quente }\end{array}$ \\
\cline { 2 - 3 } & \multicolumn{2}{c}{ Energia estimada [MJ] } \\
\hline Aquecimento dos agregados & 42.917 & 55.434 \\
\hline Aquecimento da água & 4.099 & 4.099 \\
\hline Vaporização d'água & 29.279 & 29.279 \\
\hline Aquecimento do vapor & 1.083 & 1.926 \\
\hline Total & 77.378 & \\
\hline $\begin{array}{c}\text { Redução de energia com os agregados } \\
\text { na mistura morna [\%] }\end{array}$ & \multicolumn{2}{|c}{15} \\
\hline
\end{tabular}


Sabe-se que a usina da Basalto/Estrutural costuma utilizar óleo BPF na produção de misturas asfálticas convencionais, com um consumo de cerca de 5 a $6 \mathrm{~kg}$ deste combustível por tonelada de mistura. Fixando-se a quantidade necessária de BPF em 5,5 kg/t e considerando a redução do consumo energético de $15 \%$ para produzir a mistura morna, tal consumo cairia para $4,7 \mathrm{~kg} / \mathrm{t}$. Deste modo, para usinar $450 \mathrm{t}$ de material seriam necessários aproximadamente $2.475 \mathrm{~kg}$ de óleo BPF para mistura convencional e $2.115 \mathrm{~kg}$ para a mistura morna.

Como a empresa paga cerca de $R \$ 1,34 / \mathrm{kg}$ de BPF, a estimativa de gasto de combustível para produzir a mistura convencional seria de $R \$ 3.316,50$, enquanto que na mistura morna este valor cairia para $\mathrm{R} \$ 2.834,10$, gerando uma economia de $\mathrm{R} \$ 482,40$.

Estendendo-se os cálculos para uma situação em que seria necessário pavimentar três faixas de $1 \mathrm{~km}$ de comprimento, com $3,6 \mathrm{~m}$ de largura e $3 \mathrm{~cm}$ de espessura (a mesma do trecho experimental), com uma mistura de massa específica aparente da ordem de $2,279 \mathrm{~g} / \mathrm{cm}^{3}$ (média das misturas a quente e morna verificadas em pista), estima-se que a quantidade necessária de material seria de cerca de 735 toneladas. Dentro deste contexto, verifica-se que o uso desta mistura morna levaria à uma economia de aproximadamente $R \$ 790,00$ por quilômetro executado com três pistas.

Vale frisar novamente que tais valores foram obtidos para as hipóteses adotadas e são variáveis em função de fatores como, por exemplo, temperatura ambiente, temperatura dos agregados e teor de umidade dos materiais pétreos. 


\section{CONCLUSÕES E COMENTÁRIOS FINAIS}

Por meio deste trabalho verificou-se que atualmente dispõe-se de uma série de tecnologias de misturas mornas e semimornas que permitem a redução de temperatura de usinagem e de compactação, onde algumas são de maior complexidade, e outras são mais simples e não exigem alterações de equipamentos e processos em usina ou em pista. Nesta Tese, optou-se por uma técnica simples, com o uso de aditivo surfactante acrescentado diretamente ao ligante asfáltico, resultando em menor redução de temperatura que as misturas semimornas, por exemplo, mas não menos importante do ponto de vista técnico, econômico e ambiental.

$\mathrm{Na}$ pesquisa laboratorial foram estudados três tipos de misturas asfálticas, variando-se a temperatura de aquecimento/vaporização d'água/secagem dos agregados, como forma de produzir misturas a quente e mornas. Além disso, em alguns casos também se alterou o teor de ligante para observar as mudanças relativas às propriedades de densificação e de deformação permanente.

Foram avaliados um concreto asfáltico com CAP 50-70 e graduação contínua (teor de projeto 4,4\%), uma mistura de graduação igualmente densa com CAP 30-45 (teor de projeto 5,0\%) e uma mistura com distribuição granulométrica semidescontínua tipo gap-graded com asfalto-borracha (teor de projeto 6,5\%).

Foi analisado o efeito da redução de temperatura no volume de vazios das misturas asfálticas compactadas em equipamento Marshall (impacto), em mesa compactadora (rolagem) e em prensa de cisalhamento giratório (giros). Ademais, avaliaram-se, de maneira comparativa, as propriedades mecânicas de resistência à tração, módulo de resiliência e deformação permanente das misturas em temperaturas mornas e a quente. Determinou-se ainda a resistência ao dano por umidade induzida daquelas misturas, uma vez que as misturas mornas poderiam estar mais sujeitas à ação da água, devido ao uso de menor temperatura de aquecimento dos agregados.

Nos ensaios de compactação da mistura morna com CAP 50-70, a baixa quantidade de asfalto indicada no projeto da mistura (devido à menor viscosidade deste ligante), associada ao grande nível de redução de temperatura (usinagem e 
compactação em 115 a $110^{\circ} \mathrm{C}$ ), demonstrou ter grande influência na capacidade de densificação desta mistura morna. Os dados de volume de vazios obtidos com a compactação Marshall indicaram tal dificuldade, onde mesmo com o aumento do teor de asfalto a mistura morna não conseguiu alcançar uma quantidade de vazios similar à da mistura a quente, o que certamente viria a acarretar em prejuízos quanto ao comportamento mecânico.

$\mathrm{Na}$ mesa compactadora, verificou-se a mesma tendência de dificuldade de densificação desta mistura morna no teor de projeto; o elevado volume de vazios em comparação com a mistura convencional, demonstrou a dificuldade de vencer a resistência ao cisalhamento por rolagem da mistura, com temperatura e teor de ligante muito baixos.

Em contrapartida, na prensa de cisalhamento giratório os resultados se mostraram praticamente iguais, mesmo com a diferença de temperatura, assim como foi observado por Maillard-Nunes et al. (2009) e Huner e Brown (2001). Neste caso, a energia usada para "cisalhar" o material é elevada e, apesar da diferença de temperatura, a graduação e o teor de ligante usado é que condicionam a densificação final.

Alterando-se para uma mistura asfáltica com CAP 30-45 em uma graduação densa (bem graduada), com um nível menor de redução de temperatura (usinagem e compactação em $125^{\circ} \mathrm{C}$ ), a compactação Marshall demonstrou ser estatisticamente igual entre as misturas asfálticas a quente e morna no teor de projeto. De fato, a temperatura tem grande impacto sobre o volume de vazios, onde uma provável mudança de sua magnitude pode ter sido a responsável pela diferença de vazios dos corpos de prova Marshall preparados para os ensaios mecânicos de resistência à tração e módulo de resiliência.

Já quando o estudo envolveu misturas com asfalto-borracha, que demandam elevado teor de ligante por conta da alta viscosidade deste último, a compactação Marshall e em prensa de cisalhamento giratório da mistura morna (com redução da ordem de $30^{\circ} \mathrm{C}$ ) se mostrou similar à da mistura a quente.

No caso da compactação na mesa compactadora verificou-se que a rolagem deste tipo de mistura (gap-graded com asfalto-borracha) é mais difícil que a de misturas densas (como também foi notado por Dantas Neto et al., 2006), o que pôde ser observado tanto no caso da mistura morna, quanto naquela à quente. Entretanto, alguns testes recentes que vêm sendo realizados no LTP/EPUSP têm demonstrado 
que a compactação por rolagem de misturas descontínuas ou semidescontínuas, como gap-graded e SMA, com ligantes modificados, ocorre de modo eficiente quando se aguarda até que a temperatura destas misturas se reduza significativamente no momento da compactação (da ordem de 30 a $40^{\circ} \mathrm{C}$ ), em relação àquela usualmente recomendada, de acordo com o tipo de ligante.

Fica evidente a formação de "ondas" durante a compactação, caso seja feita com rolagem de pneu (a especificação do DNIT ES112/09, por exemplo, determina que a compactação de mistura gap-graded com asfalto-borracha deve ser feita somente com rolo metálico).

Outro ponto observado nesta Tese diz respeito à tendência de volume de vazios mais elevado nos ensaios de compactação Marshall em comparação com aqueles obtidos nos projetos de mistura executados nos outros laboratórios que os forneceram. Acredita-se que pode haver diferenças relativas aos métodos de execução dos ensaios, onde uma pequena variação da massa específica máxima teórica informada, por exemplo, já seria suficiente para que o cálculo do volume de vazios sofresse uma mudança expressiva. Além disso, há o fator relativo à forma de compactação, uma vez que no LTP/EPUSP esta é feita com equipamento automático, enquanto no projeto de uma das misturas estudadas, a compactação Marshall é realizada manualmente. Dentro deste contexto, verifica-se a necessidade de se padronizar a execução deste ensaio, com o uso de normas como a ASTM D6926-10 e a NBR 15785, para que os testes apresentem melhor reprodutibilidade.

No que se refere aos ensaios de resistência à tração e de módulo de resiliência, notou-se que as misturas mornas com CAP 50-70 apresentaram queda da resistência à tração, provavelmente devido à excessiva redução de temperatura de usinagem/compactação e à pouca quantidade de ligante indicada no projeto da mistura a quente original, ocasionando elevado volume de vazios.

Já no caso das misturas com CAP 30-45, parece ter havido algum problema de temperatura na preparação dos corpos de prova Marshall para os ensaios de resistência à tração e de módulo de resiliência, resultando em misturas mornas com volume de vazios mais altos do que nas misturas a quente. Com isto, como já era de se esperar, a resistência à tração e o módulo de resiliência da mistura morna diminuíram em relação à mistura a quente. De qualquer modo, os valores encontrados de resistência à tração se enquadraram na especificação do DNIT para concretos asfálticos, mesmo sob tal condição de volume de vazios mais elevado. 
Por fim, as misturas mornas gap-graded com asfalto-borracha se mostraram estatisticamente iguais às misturas a quente, no que se refere à resistência à tração e ao módulo de resiliência.

No tocante à deformação permanente, as misturas mornas com CAP 50-70 apresentaram uma expressiva formação de trilha de roda, em comparação com a mistura a quente (praticamente o dobro no mesmo teor de ligante). Isto provavelmente ocorreu devido ao fato de esta mistura morna ter sido produzida e compactada com diminuição excessiva de temperatura, além de ser considerada "pobre" em ligante, culminando com alto volume de vazios e grande potencial para deformação permanente. Dentro deste contexto, quando houve o incremento do teor de asfalto com a finalidade de melhorar a densificação, a formação de trilha de roda aumentou ainda mais neste tipo de mistura morna. Assim, se por um lado, o uso de maiores teores de ligante na compactação Marshall já se mostrava ineficiente, ainda apontando dificuldade na densificação, por outro lado o incremento da quantidade de asfalto demonstrou ser excessivo e extremamente negativo para a deformação permanente. Com isto, verifica-se que 0 alto volume de vazios da mistura morna com CAP 50-70 comandou a formação de trilha de roda, no teor de projeto, enquanto o aumento da quantidade de ligante passou a reger a deformação permanente nos teores acima dos de projeto $(+0,3 \%$ e $+0,6 \%)$, devido à lubrificação em demasia.

No caso das misturas mornas com CAP 30-45, a deformação permanente foi praticamente igual à da mistura a quente (ligeiramente maior). Com o incremento do teor de ligante, novamente observou-se que há a elevação do potencial de formação de trilha de roda, demonstrando que a quantidade de asfalto apontada no projeto da mistura a quente deve ser mantido. Esta observação foi levada em conta quando, então, se passou a trabalhar com a mistura morna gap-graded com asfalto-borracha, cuja deformação permanente demonstrou ser igual à da mistura a quente no mesmo teor (projeto).

Com relação à resistência ao dano por umidade induzida, pode-se dizer que as misturas mornas não apresentaram diferenças com relação às misturas convencionais, demonstrando que o surfactante agiu adequadamente em todas as misturas avaliadas, compostas com agregados do tipo granito/gnaisse. Entretanto, não se sabe como seria tal comportamento caso fossem empregados agregados provenientes de outros tipos de rochas. 
Por meio da etapa laboratorial, verifica-se que o projeto da mistura asfáltica morna pode ser feito como o usual de misturas convencionais a quente no Brasil, por meio de dosagem Marshall. Tendo-se o projeto da mistura convencional, recomenda-se que a mistura morna seja executada com a mesma dosagem daquela a quente. Além disso, é essencial que a temperatura de usinagem e compactação seja controlada, para que a qualidade da mistura morna final seja semelhante à da mistura a quente, e o uso do surfactante é importante para manter a resistência ao dano por umidade. No geral, se as misturas mornas forem submetidas aos testes mecânicos com volume de vazios próximos da mistura a quente, o comportamento será semelhante quanto aos parâmetros de deformação permanente, módulo de resiliência e resistência à tração. Por outro lado, a prensa de cisalhamento giratório não se mostra efetiva para a avaliação da influência da redução de temperatura na densificação das misturas mornas.

Com relação ao trecho experimental da Rodovia Presidente Dutra pode-se dizer que o mesmo foi realizado com sucesso, com uma mistura morna de graduação contínua e com CAP 30-45. A usinagem e a compactação ocorreram sem dificuldades, do mesmo modo que seriam com uma mistura em temperatura a quente, concluindo-se que o processo construtivo é o mesmo que o convencional.

Para esta obra indicou-se um aumento do teor de ligante em relação ao projeto original, tendo sido efetivamente utilizado $+0,2 \%$. Ainda que se tenha optado por tal incremento, devido à preocupação com uma eventual dificuldade de compactação em campo por falta de lubrificação, hoje se sabe que o aumento da quantidade de asfalto na mistura morna até além da tolerância em usina não é necessário, pois a sua produção, execução e comportamento são similares à da mistura a quente, no mesmo teor de projeto desta última.

O controle tecnológico de campo, em termos de valores médios, demonstrou estabilidade mecânica da mistura morna após praticamente um ano, devendo-se considerar que este material é submetido continuamente ao tráfego muito pesado da Rodovia Presidente Dutra.

A mistura morna proveniente de usina (que foi reaquecida e moldada em laboratório a $120^{\circ} \mathrm{C}$ ) mostrou valores de resistência à tração e deformação permanente próximos ao da mistura a quente preparada em laboratório. Além disso, a resistência ao dano por umidade induzida também se manteve, inclusive em valor acima da exigência em norma, demonstrando que o aditivo não se dissipou ou 
degradou com o processo de mistura em usina e com o reaquecimento em laboratório.

Com a extração e recuperação do ligante da mistura de usina, foi possível observar, por meio de ensaios de consistência, que o envelhecimento decorrente da usinagem se mostrou dentro do aceitável na especificação brasileira (penetração retida e aumento do ponto de amolecimento).

Ademais, os testes de avaliação de superfície apontaram que a irregularidade longitudinal (QI e IRI) se mostrou dentro dos indicadores, utilizados por órgãos como a ANTT e a ARTESP. A textura, classificada como média, é decorrente da graduação densa usada, não tendo relação com o tipo de asfalto empregado.

Já no trecho experimental da Rodovia dos Bandeirantes houve a execução de segmentos em temperatura morna e a quente, com misturas de graduação gapgraded e asfalto-borracha. A mistura morna foi usinada, lançada e compactada do mesmo modo que a mistura convencional, cuja obra também foi tida como bem sucedida, onde o controle tecnológico mostrou valores de grau de compactação e volume de vazios similares em ambos os segmentos.

Da mesma maneira observada nos ensaios com as misturas fabricadas em laboratório, os testes com as misturas a quente e morna provenientes de usina (reaquecidas e compactadas nas temperaturas próximas às dos trechos) mostraram que há maior dificuldade de compactação deste tipo de material (mistura semidescontínua com ligante modificado), em comparação com misturas densas, principalmente por rolagem, uma vez que no ensaio Marshall a densificação é por impacto e na prensa de cisalhamento giratório o torque é elevado, levando a um maior nível de compactação que na mesa compactadora.

Os testes de resistência à tração com as misturas a quente e morna de usina apontaram resultados relativamente próximos, com valores acima do mínimo exigido pela especificação do DNIT, mesmo com um volume de vazios mais elevado. Igualmente, os ensaios de módulo de resiliência e dano por umidade induzida também indicaram resultados semelhantes entre as misturas a quente e morna, demonstrando comportamento análogo.

Já com relação à deformação permanente das misturas de usina, verificou-se que a compactação por rolagem deste tipo de mistura deve ser feita em temperaturas mais baixas que aquelas usualmente recomendadas, para que a densificação seja efetiva e, por consequência, o potencial ao afundamento em trilha 
de roda seja menor. Quando compactadas em temperaturas mais baixas (da ordem de $40^{\circ} \mathrm{C}$ na mistura a quente e $25^{\circ} \mathrm{C}$ na mistura morna), as misturas de usina se mostraram bastante resistentes à deformação permanente.

No mais, foi feita uma tentativa de se extrair e recuperar o ligante das misturas a quente e morna de usina para ensaios com a finalidade de verificar a variação da consistência do asfalto com a usinagem. Porém, houve dificuldade em fazê-lo, em se tratando de asfalto-borracha; observou-se a perda de elementos do ligante após a extração, já que se notou a existência de partículas remanescentes por sobre os agregados, acreditando-se tratar do negro de fumo do asfalto. Dentro deste contexto, os resultados de consistência ficariam prejudicados.

Em pista foram feitos ensaios logo após a obra do segmento de mistura a quente para a verificação da textura superficial e os valores se situaram dentro do que se considera seguro quanto à derrapagem. Supôs-se que na mistura morna a situação fosse a mesma, devido à semelhança de materiais e de dosagem, corroborada pelo aspecto visual.

Por outro lado, por se tratar de um trecho experimental mais recente que o primeiro segmento avaliado nesta pesquisa, ainda não houve levantamento de irregularidade.

Com relação à análise das emissões de poluentes em laboratório e em campo, no geral houve redução em cerca de três vezes da concentração total de HPAs relativos ao material particulado dos ambientes de mistura morna, em relação àquela a quente. Dentro deste contexto, é importante ter-se em mente que muitos dos HPAs encontrados, especialmente os maiores (com mais anéis aromáticos), são considerados possíveis agentes mutagênicos e/ou carcinogênicos, o que corrobora a informação de que os fumos asfálticos gerados em altas temperaturas possam ser mais suscetíveis à formação de HPAs carcinogênicos do que os fumos produzidos em temperaturas mais amenas, segundo mencionado por $\mathrm{NIOSH}$ (2000).

Nesta pesquisa ainda notou-se que a magnitude do total de HPAs é mais elevada em usina, em comparação com a pista, entendendo-se que isto se deva às maiores temperaturas no início do processo de pavimentação (usinagem).

É certo que em campo há uma maior dificuldade de controle do experimento, pois pode haver a interferência de fatores como vento, emissão de poluentes dos equipamentos, etc., entretanto, os resultados mostram que há esta tendência de a 
mistura a quente lançar maior quantidade de poluentes que a mistura morna, o que também pôde ser constatado visualmente, com a diminuição expressiva dos vapores e fumos de asfalto, tanto em usina quanto em pista.

Ainda que o número de amostras coletadas tenha sido limitado, trata-se de um estudo em andamento, que ainda será complementado com a avaliação dos HPAs na forma de compostos voláteis, para melhor comparação de resultados.

Complementarmente, estimou-se que houve uma economia de energia de aproximadamente $15 \%$ com a redução da temperatura de secagem/vaporização d'água/aquecimento dos agregados em usina na produção das misturas mornas, levando-se em conta as hipóteses adotadas nos cálculos.

É certo que, no caso desta técnica de mistura morna, há um investimento contínuo devido à compra do aditivo para produzi-la. Todavia, existem outros aspectos que devem ser contrabalançados com tal gasto, como a melhoria do ambiente de trabalho na pavimentação (que pode levar a um aumento da produtividade e à melhoria da saúde dos operários) e a possibilidade de lucro com a venda de créditos de carbono, caso esta iniciativa seja inserida em projetos de MDL. Além disso, é difícil computar os ganhos referentes ao maior tempo disponível para execução dos serviços de pavimentação asfáltica, pois as misturas mornas apresentam um menor gradiente térmico em relação às misturas a quente (NEWCOMB, 2006; PROWELL e HURLEY, 2007). Dentro deste contexto, têm-se menores riscos relativos ao resfriamento da mistura asfáltica, que podem levar à perda de material, com os serviços noturnos sendo favorecidos, especialmente em casos de obras especiais, pista de tráfego com restrições operacionais de fechamento de faixas para manutenção e em aeroportos onde a possibilidade de manutenção por diversas vezes somente pode ser realizada no período noturno.

Cabe mencionar que ainda é necessário um estudo relativo à fadiga destas misturas mornas, uma vez que este parâmetro mecânico também é de suma importância na pavimentação, pois envolve a durabilidade do material em longo prazo. Ainda que, de modo geral, os resultados dos ensaios mecânicos realizados nesta pesquisa tenham demonstrado comportamento semelhante entre a mistura morna e a mistura convencional, é possível que a redução da temperatura de usinagem/compactação tenha impacto positivo sobre a questão do envelhecimento do ligante, influenciando no comportamento à fadiga. Dentro deste contexto, também 
fica evidente a necessidade de estudos relativos à reologia dos asfaltos que compõem estas misturas mornas, em comparação com misturas usinadas a quente.

No geral, esta Tese demonstra que o controle de temperatura é essencial para o sucesso da técnica, pois tem impacto nas propriedades mecânicas das misturas asfálticas mornas, e a diminuição de temperatura dos agregados em cerca de $30^{\circ} \mathrm{C}$ com o uso de aditivo surfactante é adequada para esta tecnologia de mistura morna. Além disso, pelas propriedades físicas e mecânicas avaliadas em laboratório e em campo, verifica-se que a qualidade das misturas asfálticas mornas é similar às usinadas a quente, com o benefício da redução das emissões de poluentes (em particular de HPAs) e economia de combustíveis. 


\section{REFERÊNCIAS}

AGÊNCIA NACIONAL DO PETRÓLEO, GÁS NATURAL E BIOCOMBUSTÍVEIS. Resolução ANP n 19 de 11.07.2005. Rio de Janeiro, 2005. Disponível em: <http://nxt.anp.gov.br>. Acesso em: 30 abr. 2011.

. Resolução ANP n 39 de 24.12.2008. Rio de Janeiro, 2008. Disponível em: $<$ http://nxt.anp.gov.br>. Acesso em: 30 abr. 2011.

AGENCY FOR TOXIC SUBSTANCES \& DISEASE REGISTRY. 2008. Case studies in environmental medicine (CSEM): Toxicity of polycyclic aromatic hydrocarbons (PAHs): What health effects are associated with PAH exposure? Disponível em: <http://www.atsdr.cdc.gov $>$. Acesso em: 30. abr. 2011.

AMERICAN ASSOCIATION OF STATE HIGHWAY AND TRANSPORTATION OFFICIALS. AASHTO T269: Standard method of test for percent air voids in compacted dense and open asphalt mixtures. Washington, 1997.

. AASHTO T209: Standard method of test for theoretical maximum specific gravity and density of hot mix asphalt (HMA). Washington, 1999.

. AASHTO T85. Standard method of test for specific gravity and absorption of coarse aggregate. Washington, 2004.

. AASHTO T11: Standard method of test for materials finer than $75-\mu m\left(n^{\circ} 200\right)$ sieve in mineral aggregates by washing. Washington, 2005.

. AASHTO T228: Standard method of test for specific gravity of semi-solid asphalt materials. Washington, 2006.

. AASHTO T27: Standard method of test for sieve analysis of fine and coarse aggregates. Washington, 2006.

. AASHTO T166: Standard method of test for bulk specific gravity of compacted hot mix asphalt (HMA) using saturated surface-dry specimens. Washington, 2007.

. AASHTO T283: Standard method of test for resistance of hot mix asphalt (HMA) to moistureinduced damage. Washington, 2007.

. AASHTO T84: Standard method of test for specific gravity and absorption of fine aggregate. Washington, 2008.

. AASHTO R35: Standard practice for Superpave volumetric design for hot mix asphalt (HMA). Washington, 2009.

AMERICAN SOCIETY FOR TESTING AND MATERIALS. ASTM D1856: Standard test method for recovery of asphalt from solution by Abson method. West Conshohocken, 1995.

. ASTM D2493: Standard viscosity-temperature chart for asphalts. West Conshohocken, 2001. . ASTM D2872. Standard test method for effect of heat and air on a moving film of asphalt (Rolling Thin-Film Oven Test). West Conshohocken, 2004.

. ASTM D4402: Standard test method for viscosity determination of asphalt at elevated temperatures using a rotational viscometer. West Conshohocken, 2006.

. ASTM E965: Standard test method for measuring pavement macrotexture depth using a volumetric technique. West Conshohocken, 2006.

. ASTM D1188: Standard test method for bulk specific gravity and density of compacted bituminous mixtures using coated samples. West Conshohocken, 2007.

. ASTM E303: Standard test method for measuring surface frictional properties using the British pendulum tester. West Conshohocken, 2008.

. ASTM D4867: Standard test method for effect of moisture on asphalt concrete paving mixtures. West Conshohocken, 2009.

. ASTM D2726: Standard test method for bulk specific gravity and density of non-absorptive compacted bituminous mixtures. West Conshohocken, 2010.

ASTM D6926: Standard practice for preparation of bituminous specimens using Marshall apparatus. West Conshohocken, 2010. 
ANTONELLO, E. L.; MORILHA JR, A. WMA: Misturas mornas através do processo de espuma em usinas de asfalto. Conferência proferida durante o $4^{\circ}$ CONGRESSO DE INFRAESTRUTURA DE TRANSPORTES. São Paulo, 2010.

ASPHALT INSTITUTE. The Asphalt Handbook. MS-4. $7^{\text {th }}$ edit. Asphalt Institute, 2007.

ASSOCIAÇÃO BRASILEIRA DE NORMAS TÉCNICAS. NBR 12891: Dosagem de misturas betuminosas pelo método Marshall: Procedimento. Rio de Janeiro, 1993.

. NBR 6560: Materiais betuminosos: Determinação do ponto de amolecimento: Método do anel e bola. Rio de Janeiro, 2000.

NBR 14950: Materiais betuminosos: Determinação da viscosidade Saybolt-Furol. Rio de Janeiro, 2003.

. NBR 15087: Misturas asfálticas :Determinação da resistência à tração por compressão diametral. Rio de Janeiro, 2004.

NBR 6296: Produtos betuminosos semi-sólidos: Determinação da massa específica e densidade relativa. Rio de Janeiro, 2004.

. NBR 15529: Asfalto borracha: Propriedades reológicas de materiais não newtonianos por viscosímetro rotacional. Rio de Janeiro, 2007.

. NBR 6576: Materiais asfálticos: Determinação da penetração. Rio de Janeiro, 2007.

. NBR 15617: Misturas asfálticas: Resistência do dano por umidade induzida. Rio de Janeiro, 2008.

. NBR 7809: Agregado graúdo: Determinação do índice de forma pelo método do paquímetro: Método de ensaio. Rio de Janeiro, 2008.

. NBR 15785: Misturas asfálticas a quente: Utilização da aparelhagem Marshall para preparação dos corpos-de-prova com diferentes dimensões e aplicações. Rio de Janeiro, 2010.

ASSOCIATION FRANÇAISE DE NORMALISATION. AFNOR NF-P-98-130: Enrobés hydrocarbonés: Couches de roulement et couches de liaison : Bétons bitumineux semi-grenus (BBSG). Association Française de Normalisation, France, 1999a.

. AFNOR NF-P-98-252: Essais relatifs aux chaussées: Détermination du comportement au compactage des mélanges hydrocarbonés: Essai de compactage à la presse à cisaillement giratoire (PCG). Association Française de Normalisation, France, 1999b.

BAIRD, C. Environmental chemistry. New York W.H. Freeman. $2^{\text {nd }}$ ed. 1999.

BARTHEL, W.; MARCHAND, J.-P.; von DEVIVERE, M. Warm asphalt mixes by adding a synthetic zeolite. In: EURASPHALT \& EUROBITUME CONGRESS, 3., 2004, Vienna. Anais..., n. 354.

BERNUCCI, L. B.; MOTTA, L. M. G.; CERATTI, J. A. P.; SOARES, J. B. Pavimentação asfáltica: Formação básica para engenheiros. Rio de Janeiro: PETROBRAS: ABEDA, 3ª reimp., 2008.

BROSSEAUD, Y. Warm asphalt: Overview in France. Conferência proferida durante 0 INTERNATIONAL WARM-MIX ASPHALT CONFERENCE. Nashville, 2008.

BROWN, E. R., KANDHAL, P. S., ROBERTS, F. L., KIM, Y.R., LEE, D.-Y., KENNEDY, T. W. Hot mix asphalt: Materials, mixture design, and construction. Lanham: NCAT at Auburn University, $3^{\text {rd }}$ ed., 2009.

CAVALCANTI, L. S.; MOTTA, L. M. G.; ODA, S. Análise do comportamento mecânico de misturas asfálticas tipo warm-mix com uso de aditivo surfactante. In: ENCONTRO DE ASFALTO, 20., 2010, Rio de Janeiro. Anais.... Rio de Janeiro: Instituto Brasileiro de Petróleo, Gás e Biocombustíveis, 2010.

CENTRO DE GESTÃO E ESTUDOS ESTRATÉGICOS. Manual de capacitação: mudança climática e projetos de mecanismo de desenvolvimento limpo. Brasília: Ministério da Ciência e Tecnologia, 2008. Disponível em: <http://www.cgee.org.br>. Acesso em: 13 fev. 2009.

CHOWDHURY, A.; BUTTON, J. W. A review of warm mix asphalt. Technical Report. Texas Transportation Institute: 2008. Disponível em: <http://swutc.tamu.edu>. Acesso em 30 abr. 2011.

COMITÉ EUROPÉEN DE NORMALISATION. EN 12697-33: Mélange bitumineux: Méthodes d'essai pour mélange hydrocarboné à chaud: Partie 33: Confection d'éprouvettes au compacteur de plaque. Version française. Bruxelles, 2003a. . EN 12697-22: Mélanges bitumineux: Méthodes d'essai pour mélange hydrocarboné à chaud: Partie 22: Essai d'orniérage. Version française. Bruxelles, 2003b. 
. EN 13108-2: Mélanges bitumineux: Spécifications des matériaux: Partie 2: Bétons bitumineux très minces. Version française. Bruxelles, 2006.

CONSELHO NACIONAL DE MEIO AMBIENTE. Resolução CONAMA n 382 de 26.12.2006. Disponível em: <http://www.mma.gov.br>. Acesso em: 30 abr. 2011.

COOPER, C. D.; ALLEY, F. C. Air pollution control: a design approach. $3^{\text {rd }}$ ed. Prospect Heights, III: Waveland Press, 2002.

COOPER, C. D.; DIETZ, J. D.; REINHART, D. R. Foundations of environmental engineering. Prospect Heights, III: Waveland, 2000.

COPELAND, A.; D'ANGELO, J.; DONGRE, R.; BELAGUTTI, S.; SHOLAR, G. Field evaluation of a high reclaimed asphalt pavement/warm mix asphalt project in Florida: A case study. In: TRANSPORTATION RESEARCH BOARD ANNUAL MEETING, 89., 2010, Washington. Anais... Washington: TRB, 2010.

CRAVO, M. C. C. Estudos relacionados aos fumos de asfalto. Conferência proferida durante $\circ 3^{\circ}$ WORKSHOP EM SMS - COMISSÃO DE ASFALTO DO IBP. São Paulo, 2010.

CRAVO, M. C. C.; LEITE, L. M. F.; MARTINS, A. T.; MONTEIRO, R. J. C.; AZEVEDO, R. A.; BOHRER, D.; NASCIMENTO, P. Estudo toxicológico dos CAPs brasileiros. In: ENCONTRO DE ASFALTO, 20., 2010, Rio de Janeiro. Anais.... Rio de Janeiro: Instituto Brasileiro de Petróleo, Gás e Biocombustíveis, 2010.

D'ANGELO, J.; HARM, E.; BARTOSZEK, J.; BAUMGARDNER, G.; CORRIGAN, M.; COWSERT, J.; HARMAN, T.; JAMSHIDI, M.; JONES, W.; NEWCOMB, D.; PROWELL, B.; SINES, R.; YEATON, B. Warm-mix asphalt: European practice. International Technology Scanning Program. Virginia: Federal Highway Administration, 2008.

DANTAS NETO, S. A.; FARIAS, M. M.; PAIS, J. C. Comportamento mecânico de misturas asfálticas de graduação descontínua (gap graded). In: ENCONTRO DE ASFALTO, 18., 2006, Rio de Janeiro. Anais.... Rio de Janeiro: Instituto Brasileiro de Petróleo, Gás e Biocombustíveis, 2006.

DELORME, J-L.; LA ROCHE, C.; WENDLING, L. Manuel LPC d'aide à la formulation des enrobes. Paris: LCPC, 2007.

DEPARTAMENTO NACIONAL DE ESTRADAS DE RODAGEM. DNER ME133/94: Misturas betuminosas: Determinação do módulo de resiliência: Método de ensaio. Rio de Janeiro, 1994.

. DNER ME043/95: Misturas betuminosas a quente: Ensaio Marshall. Rio de Janeiro, 1995.

DEPARTAMENTO NACIONAL DE INFRAESTRUTURA DE TRANSPORTES. DNIT ES031/06:

Pavimentos flexíveis: Concreto asfáltico: Especificação de serviço. Rio de Janeiro, 2006.

. DNIT ES112/09: Pavimentos flexíveis: Concreto asfáltico com asfalto-borracha, via úmida, do tipo "Terminal Blending": Especificação de serviço. Rio de Janeiro, 2009. . IPR-720: Manual de restauração de pavimentos asfálticos. DNIT, 2006.

DIEFENDERFER, S. D.; HEARON, A. J.; MCGHEE, K. K. Installation of warm mix asphalt projects in Virginia. In: TRANSPORTATION RESEARCH BOARD ANNUAL MEETING, 87., 2008, Washington. Anais... Washington: TRB, 2008.

DOYLE, J. D.; HOWARD, I. L. Compactability and bitumen utilization of $100 \%$ warm mixed RAP. In: TRANSPORTATION RESEARCH BOARD ANNUAL MEETING, 89., 2010, Washington. Anais... Washington: TRB, 2010.

EKSTRÖM, L-G.; KRIECH, A.; BOWEN, C.; JOHNSON, S.; BREUER, D. International studies to compare methods for personal sampling of bitumen fumes. Journal of Environmental Monitoring, 3, 439-445, 2001.

FEDERAL HIGHWAY ADMINISTRATION. Warm mix asphalt technologies and research. Disponível em: <http://www.fhwa.dot.gov>. Acesso em: 20 fev. 2011.

FERNANDES, P. R. N.; SOARES, . A.; NASCIMENTO, R. F.; SOARES, J. B.; CAVALCANTE, R. M. Evaluation of polycyclic aromatic hydrocarbons in asphalt binder using matrix solid-phase dispersion and gas chromatography. Journal of Chromatography Science, v. 47, 789-793, 2009.

FERREIRA, C. I. G. Avaliação do desempenho de misturas betuminosas temperadas. 2009. 140 p. Dissertação (Mestrado) - Escola de Engenharia, Universidade do Minho, Portugal, 2009.

FÓRUM BRASILEIRO DE MUDANÇAS CLIMÁTICAS. Reunião Anual com Presidente da República. 2010. Disponível em: <http://www.forumclima.org.br>. Acesso em: 30 abr. 2011. 
FRITZEN, M. A.; MOTTA, L. M. G.; NASCIMENTO, L. A.H.; CHACUR, M. Comportamento de misturas asfálticas mornas submetidas a ensaios acelerados por simulador de tráfego móvel. In: SIMPÓSIO INTERNACIONAL DE AVALIAÇÃO DE PAVIMENTOS E PROJETOS DE REFORÇO, 4., 2009, Fortaleza. Anais... Rio de Janeiro: ABPv, 2009.

GASTHAUER, E.; MAZÉ, M.; MARCHAND, J. P.; AMOUROUX, J. Characterization of asphalt fume composition by GC/MS and effect of temperature. Fuel, 87, 1428-1434, 2008.

GAUDEFROY, V.; DEYGOUT, F.; VIRANAIKEN, V.; LE COUTALLER, P.; PARANHOS, R., LA $\mathrm{ROCHE}, \mathrm{C}$. Laboratory identification of fumes during manufacturing of hydrocarbons mixtures. In: INTERNATIONAL SOCIETY FOR ASPHALT PAVEMENTS, Zürich. Anais... 2008.

GONZÁLEZ-LEÓN, J. A.; GRAMPRE, L.; BARRETO, G.; In: TRANSPORTATION RESEARCH BOARD ANNUAL MEETING, 88., 2009, Washington. Anais... Washington: TRB, 2009.

HAMZAH, M. O.; JAMSHIDI, A.; ZULKURNAIN, S. Evaluation of the potential of Sasobit ${ }^{\circledR}$ to reduce required heat energy and $\mathrm{CO}_{2}$ emission in the asphalt industry. Journal of Cleaner Production, 18, 1859-1865, 2010.

HANZ, A. J.; FAHEEM, A.; MAHMOUD, E.; BAHIA, H. U. Measuring effects of warm mix additives using a newly developed asphalt binder lubricity test for the DSR. In: TRANSPORTATION RESEARCH BOARD ANNUAL MEETING, 89., 2010, Washington. Anais... Washington: TRB, 2010.

HARDER, G.; LEGOFF, Y.; LOUSTAU, A.; MARTINEAU, Y.; HERITIER, B.; ROMIER, A. Energy and environmental gains of warm and half-warm asphalt mix: quantitative approach. In: TRANSPORTATION RESEARCH BOARD ANNUAL MEETING, 87., 2008, Washington. Anais... Washington: TRB, 2008.

HASSAN, M. M. Life-cycle assessment of warm-mix asphalt: an environmental and economic perspective. In: TRANSPORTATION RESEARCH BOARD ANNUAL MEETING, 88., 2009, Washington. Anais... Washington: TRB, 2009.

HUBER, G. A.; DECKER, D. S. Engineering properties of asphalt mixtures and the relationship to their performance. STP 1265. Philadelphia: ASTM, 1995.

HUNER, L. M. H.; BROWN, E. R. Effects of re-heating and compaction temperature on hot mix asphalt volumetrics. Report 01-04. Auburn: NCAT, 2001.

HURLEY, G. C.; PROWELL, B. D. Evaluation of Aspha-Min ${ }^{\circledR}$ zeolite for use in warm mix asphalt. Report 05-04. Auburn: NCAT, 2005a.

HURLEY, G. C.; PROWELL, B. D. Evaluation of Sasobit ${ }^{\circledR}$ for use in warm mix asphalt. Report 05-06. Auburn: NCAT, 2005b.

HURLEY, G. C.; PROWELL, B. D. Evaluation of Evotherm ${ }^{\circledR}$ for use in warm mix asphalt. Report 0602. Auburn: NCAT, 2006.

HURLEY, G. C.; PROWELL, B. D. Field performance of warm mix asphalt. In: TRANSPORTATION RESEARCH BOARD ANNUAL MEETING, 87., 2008, Washington. Anais... Washington: TRB, 2008.

INTERGOVERNMENTAL PANEL ON CLIMATE CHANGE. Climate Change 2007: Synthesis Report. 2007. Disponível em: <http://www.ipcc.ch>. Acesso em: 10 jul. 2009.

KESHAVA, N.; ONG, T-M. Occupational exposure to genotoxic agents. Mutation Research, 437, 175194, 1999.

KRISTJÁNSDÓTTIR, Ó.; MUENCH, S.; MICHAEL, L.; BURKE, G. Assessing the potential for warm mix asphalt technology adoption. In: TRANSPORTATION RESEARCH BOARD ANNUAL MEETING, 86., 2007, Washington. Anais... Washington: TRB, 2007.

LA ROCHE, C.; GAUDEFROY, V.; VIRANAIKEN, V.; PARANHOS, R. A new experimental trial protocol for laboratory investigations of bitumen fumes: Influence of stirring and steamed water on emissions. In: INTERNATIONAL SOCIETY FOR ASPHALT PAVEMENTS, Zürich. Anais... 2008.

LABORATÓRIO DE PAVIMENTAÇÃO DA UNIVERSIDADE FEDERAL DO RIO GRANDE DO SUL; CONCEPA. Estudo laboratorial de comportamento à fadiga e deformação permanente de misturas asfálticas mornas. Relatório Final. Porto Alegre, 2008.

LABORATORIO DE TRANSPORTE DE ESPAÑA. NLT 329/91: Recuperación elástica por torsión de betunes asfálticos modificados. CEDEX, 1991.

LECOMTE, M.; DEYGOUT, F.; MENETTI, A. Emission and occupational exposure of lower asphalt production and laying temperatures. Apresentado a 23 World Road Congress, 23., Paris, 2007. 
MAILLARD-NUNES, P.; DONY, A.; KLINCEVICIOUS, M.; MOTTA, R.; BERNUCCI, L.; DEL PRIORE, C.; BROSSEAUD, Y.; GAUDEFROY, V.; COLIN, J. Warm mixes asphalt: Laboratory evaluation of two mix design methods. In: SIMPÓSIO INTERNACIONAL DE AVALIAÇÃO DE PAVIMENTOS E PROJETOS DE REFORÇO, 4., 2009, Fortaleza. Anais... Rio de Janeiro: ABPv, 2009.

MALLICK, R. B.; BERGENDAHL, J.; PAKULA, M. A laboratory study on $\mathrm{CO}_{2}$ emission reductions through the use of warm mix asphalt. In: TRANSPORTATION RESEARCH BOARD ANNUAL MEETING, 88., 2009, Washington. Anais... Washington: TRB, 2009.

MALLICK, R. B.; KANDHAL, P. S.; BRADBURY, R. L. Using warm mix asphalt technology to incorporate high percentage of reclaimed asphalt pavement (RAP) material in asphalt mixtures. In: TRANSPORTATION RESEARCH BOARD ANNUAL MEETING, 87., 2008, Washington. Anais... Washington: TRB, 2008.

MARCHAND, J. P.; SOLIMAN, S.; VON DEVIVERE, M.; SAUGET, A.; HARNISCHFEGER, S.; BARTHEL, W. Performance and environmental assessment of the warm bituminous mixes with Aspha-Min ${ }^{\circledR}$. In: EUROASPHALT \& EUROBITUME CONGRESS, 4., Copenhagen. Anais... 2008.

MIDDLETON, B.; FORFYLOW, R. W. An evaluation of warm mix asphalt produced with the Double Barrel $^{\otimes}$ Green Process. In: TRANSPORTATION RESEARCH BOARD ANNUAL MEETING, 88., 2009, Washington. Anais... Washington: TRB, 2009.

MOTTA, L. M. G.; FRITZEN, M. A., VIANNA, A. A. D.; ÁVILA, G. M.; BARRA, R. Avaliação do comportamento de dois tipos de revestimentos asfálticos, dosados pelo método SUPERPAVE, sob ação de tráfego real na Rodovia BR040 - Trecho da Concessionária CONCER. In: WORKSHOP DESENVOLVIMENTO TECNOLÓGICO NAS CONCESSÕES RODOVIÁRIAS: SOLUÇÕES TÉCNICAS APLICADAS, 5., 2010. Brasília. Anais... Brasília: ANTT, 2010.

NATIONAL CENTER FOR ASPHALT TECHNOLOGY. Evaluating warm-mix asphalt field performance. Disponível em: <http://eng.auburn.edu>. Acesso em: 18 jan. 2011.

NATIONAL INSTITUTE FOR OCCUPATIONAL SAFETY AND HEALTH. Health effects of occupational exposure to asphalt: Hazard review. 2000. Disponível em: <www.cdc.gov/niosh $>$. Acesso em: 25 jun. 2009.

NEITZKE, B.; WASILL, B. Placement of warm mix asphalt on the east entrance road of Yellowstone National Park. Washington: Federal Highway Administration, 2009. Disponível em: $<$ http://www.cflhd.gov>. Acesso em 22 fev. 2011.

NEWCOMB, D. An introduction to warm-mix asphalt. 2006. National Asphalt Pavement Association, Lanham. Disponível em: <http://fs1.hotmix.org>. Acesso em: 10 jul. 2009.

OLARD, F. Low energy asphalts. Routes Roads, n. 336-337, p. 131-145, 2008. Apresentado a 23 World Road Congress: General Report and Conclusions: PIARC Prizes, 23., Paris, 2008.

ORGANIZAÇÃO DOS PAÍSES EXPORTADORES DE PETRÓLEO. OPEC Basket Price. 2010. Disponível em: <http://www.opec.org>. Acesso em: 29 abr. 2010.

OSBORNE, M. R.; CROSBY, N T. Benzopyrenes. Cambridge Monographs on Cancer Research. New York: Cambridge University Press, 1987.

OTTO, G. G. Misturas asfálticas mornas: Verificação da fadiga e do módulo complexo. 179 p. Dissertação (Mestrado) - Universidade Federal de Santa Catarina, Florianópolis, 2009.

PAVIA SYSTEMS; NATIONAL ASPHALT PAVEMENT ASSOCIATION. Warm mix asphalt. Disponível em: <http://www.paviasystems.com>. Acesso em: 26 out. 2010.

PINHEIRO, L. S.; FERNANDES, P. R. N.; CAVALCANTE, R. M.; NASCIMENTO, R. F.; SOARES, J. B.; SOARES, S. A.; FREIRE, J. A. K. Polycyclic aromatic hydrocarbons from asphalt binder: Extraction and characterization. Journal of the Brazilian Chemical Society, v. 20, n. 2, 222228, 2009

PROWELL, B. D.; HURLEY, G. C. Warm-mix asphalt: Best Practices. Quality Improvement Series 125. Lanham: NATIONAL ASPHALT PAVEMENT ASSOCIATION, 2007.

PROWELL, B. D.; HURLEY, G. C.; CREWS, E. Field performance of warm mix asphalt at the NCAT test track. In: TRANSPORTATION RESEARCH BOARD ANNUAL MEETING, 86., 2007, Washington. Anais... Washington: TRB, 2007.

RAVINDRA, K.; SOKHI, R.; VAN GRIEKEN, R. Atmospheric polycyclic aromatic hydrocarbons: Source attribution, emission factors and regulation. Atmospheric Environment, 42, 2895-2921, 2008. 
RHODE, L.; CERATTI, J. A. P.; TREICHEL, D. Estudo laboratorial de misturas asfálticas "mornas". In: 39를 Reunião Anual de Pavimentação e $13^{\circ}$ Encontro Nacional de Conservação Rodoviária, 2008, Recife. Anais... Rio de Janeiro: ABPv, 2008.

ROCHA, M. T. Aquecimento global e o mercado de carbono: uma aplicação do modelo CERT. 2003. 214 p. Tese (Doutorado) - Escola Superior de Agricultura "Luiz de Queiroz", Universidade de São Paulo, Piracicaba, 2003.

ROMIER, A.; AUDEON, M.; DAVID, J.; MARTINEAU, Y.; OLARD, F. Low-energy asphalt (LEA $\left.{ }^{\circledR}\right)$ with the performance of hot-mix asphalt. In: TRANSPORTATION RESEARCH BOARD ANNUAL MEETING, 85., 2006, Washington. Anais... Washington: TRB, 2006.

RÜHL, R. Lower temperatures: The best for asphalt, bitumen, environment and health and safety. In: EURASPHALT \& EUROBITUME CONGRESS, 4., 2008, Copenhagen. Anais... 2008.

SANTOS, F. C. Determinação de compostos orgânicos no material particulado (MP10) atmosférico do Estado de São Paulo. 2010. 110p. Dissertação (Mestrado) - Instituto de Química, Universidade de São Paulo, São Paulo, 2010.

SCHREINER, C. A. Review of mechanistic studies relevant to the potential carcinogenicity of asphalts. Regulatory Toxicology and Pharmacology, 59, 270-284, 2011.

SEBAALY, P. E.; BAZI, G.; HITTI, E.; WEITZEL, D.; BEMANIAN, S. Performance of cold inplace recycling in Nevada". Transportation Research Record, 1869, 162-169, 2004.

SILVA, H. M. R. D.; OLIVEIRA, J. R. M.; PERALTA, J.; ZOOROB, S. E. Optimization of warm mix asphalts using different blends of binders and synthetic paraffin wax contents. Construction and Building Materials, 24, 1621-1631, 2010.

SOUSA FILHO, A. C. Produção de misturas asfálticas mornas pela inserção de zeólitas. 2006. Dissertação (Mestrado) - Universidade Federal do Ceará, Fortaleza, 2006.

SUPERPAVE. Superpave Mix Design Series n.2 (SP-2). $3^{\text {rd }}$ ed. Asphalt Institute, 2001.

UNITED NATIONS FRAMEWORK CONVENTION ON CLIMATE CHANGE. Kyoto Protocol. 2005. Disponível em: <http://unfccc.int>. Acesso em: 10 fev. 2009.

VASCONCELLOS, P. C.; SOUZA, D. Z.; SANCHEZ-CCOYLLO, O.; BUSTILLOS, J. O. V.; LEE, H.; SANTOS, F. C.; NASCIMENTO, K. H.; ARAÚJO, M. P.; SAARNIO, K.; TEINILA, K.; HILLAMO, R. Determination of anthropogenic and biogenic compounds on atmospheric aerosol collected in urban, biomass burning and forest areas in Sao Paulo, Brazil. Science of the Total Environment. 408, 5836-5844, 2010.

WASIUDDIN, N. M.; SELVAMOHAN, S.; ZAMAN, M. M.; GUEGAN, M. L. T. A. A comparative laboratory study of Sasobit ${ }^{\circledR}$ and Aspha-Min ${ }^{\circledR}$ in warm mix asphalt. In: TRANSPORTATION RESEARCH BOARD ANNUAL MEETING, 86., 2007, Washington. Anais... Washington: TRB, 2007.

WATTS, R. R; WALLINGFORD, K. M.; WILLIAMS, R. W; HOUSE, D. E.; LEWTAS, J. Airborne exposures to $\mathrm{PAH}$ and PM2.5 particles for road paving workers applying conventional asphalt and crumb rubber modified asphalt. Journal of Exposure Analysis and Environmental Epidemiology, 8, 213-229, 1998.

XIAO, F.; ZHAO, P. E. W.; AMIRKHANIAN, S. N. Fatigue behavior of rubberized asphalt concrete mixtures containing warm asphalt additives. Construction and Building Materials, 23, 31443151, 2009.

XIAO, F.; AMIRKHANIAN, S. N.; PUTMAN, B. J. Evaluation of rutting resistance in warm mix asphalts containing moist aggregate. In: TRANSPORTATION RESEARCH BOARD ANNUAL MEETING, 89., 2010, Washington. Anais... Washington: TRB, 2010.

YASSAA, N.; MEKLATI, B. Y.; CECINATO, A.; MARINO, F. Chemical characteristics of organic aerosol in Bab-Ezzouar (Algiers): Contribution of bituminous product manufacture. Chemosphere, 45, 315-322, 2001. 